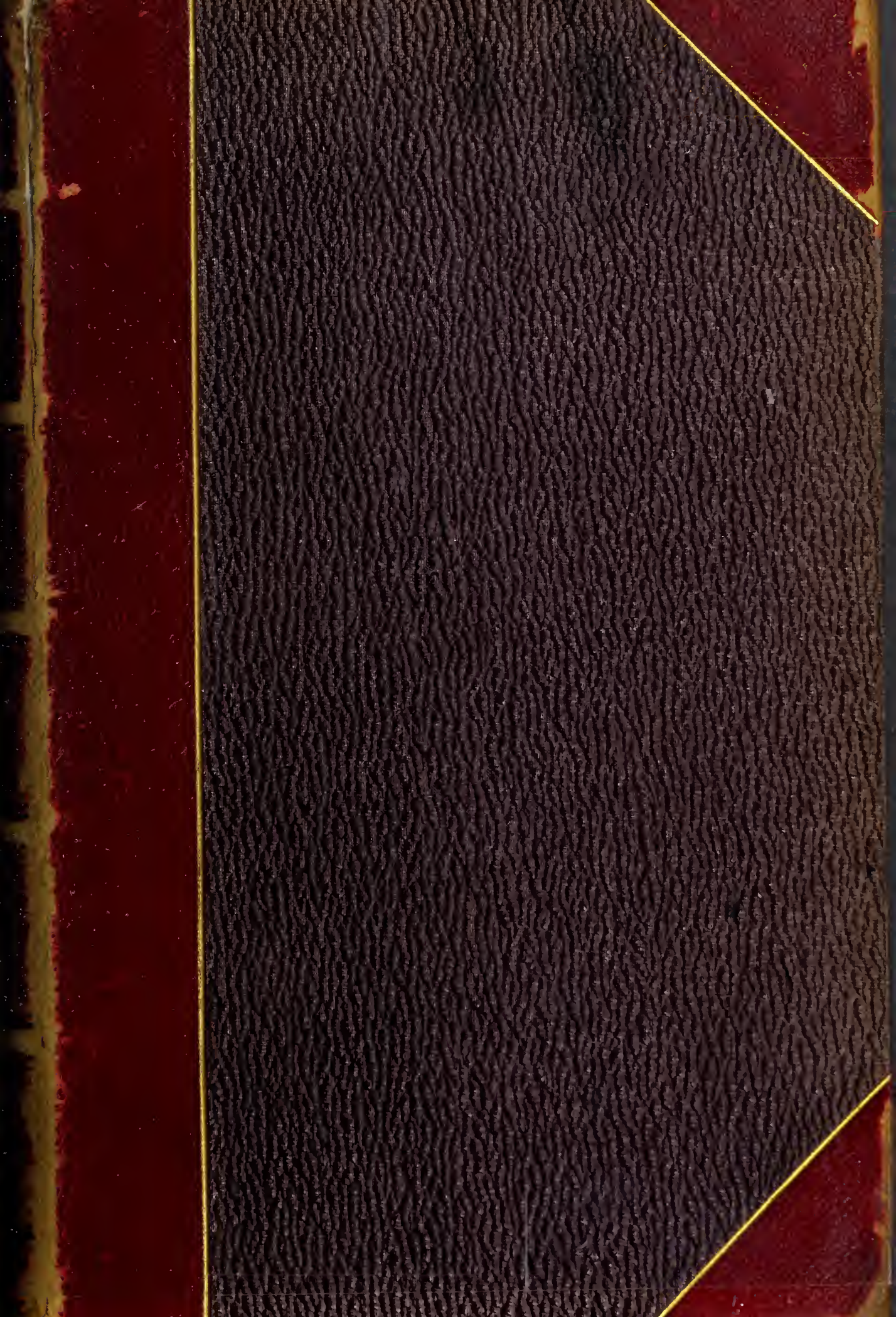




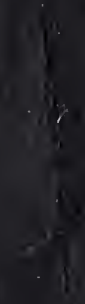




\section{CORNISH FAUNA;}

BEING A COMPENDIUM

OF THE

\section{NATURAL HISTORY}

OF

\section{THE COUNTY,}

Intended to form a Companion to the Collection in the Museum of the Royal Institution of Cornwall.

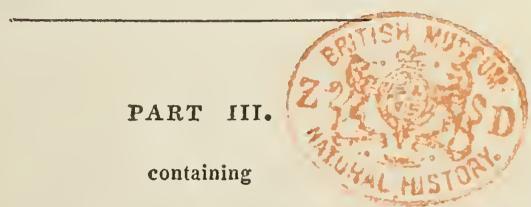

$\checkmark$

THE ZOOPHYTES AND CALCAREOUS CORALLINES.

By RICHARD Q. COUCH, M.R.C.S.L.

TRURO :

Printed for the Royal Institution of Cornwall,

BY L. E. GILLET.

1844. 



\section{PREFACE.}

$I_{T}$ would be but an idle employment of time to expatiate on the pleasures of the study of nature, since they must be obvious to all. To view her boundless diversity of forms and gradations; to become acquainted, in fact, with creation is to be enamoured of her charms. Her productions are every where to be found, and every where inviting attention; they are so many and so various, the laws by which she governs them so extensive and beautiful, that none of her followers ever yet complained of satiety or disgust; on the contrary, to investigate her works gives health to the body, vigour to the mind, and yields an inexhaustable fund of amusement and delight. As it neither requires confinement, sedentary habits nor expensive instruments to study it with success, it may be pursued by the poor as well as the rich.

But as the productions of nature are so very extensive and diversified, it has been found necessary, for the conveniency of study, to divide and arrange them into small departments. The advantages of this must be ob- 
vious; students generally confine their attention to one or more divisions, each thereby becomes more thoroughly investigated and the whole better understood. Some repartments, however, either from their brilliancy or easiness of access, have always been greater favourites and have had more cultivators than others. In this country, Birds and Insects have had, with the exception of Botany, more followers than all the others together, while the Zoophytes have suffered a very general neglect. In the following pages an attempt is made to rescue them from this obscurity, or such of them as are found upon the Cornish coast; they are, it is true, very unobtrusive, and compared with similar productions from warmer seas, insignificant; yet they are interesting, as being our representatives of creatures which have acted and are still acting, an important part in the mutations of the earth's surface.

The species here described are ascertained to be Cornish from personal inspection and researches both in deep water and near the shores. The list will be found very extensive, and to embrace nearly all that have hitherto been recognized as British, beside many others quite new and described here for the first time.

In these researches I have been greatly assisted by my indefatigable friend Mr. Peach of Goran, who has spared neither time nor trouble 
in procuring specimens from a variety of localities, that they might be examined under a variety of circumstances, and their true character more satisfactorily ascertained. The materials thus accumulated would never have taken any other form than papers to different societies, had it not been thought desirable to have a Cornish Fauna as perfect as the present state of our knowledge would allow.

The importance of local Faunas is too generally allowed to require any advocacy now. By the investigation of circumscribed localities, the habits and economy of animated nature are more minutely observed and better understood than when studied in the mass. The same animals being found in different parts of the world, they are thus examined under such a variety of circumstances, that we become more intimately acquainted with them. It should always be remembered that neither Beasts, Birds, Fishes, nor any other animals, are scattered indiscriminately through the earth, but are confined in groups to particular zones of climate; and nature beautifully adapts her productions to the situations they are destined to occupy. The migration of animals, which has hitherto baffled the researches of naturalists, will probably receive its elucidation from these local registers. If after repeated observation it be found that certain creatures periodically visit and leave certain regions, it scems the most 
rational to suppose that an explanation is to be found, either in the condition of the earth's surface, climate or change of the seasons, the supply of food, or some other cause depending on local peculiarities.

It is by these local Faunas that the Geographical distribution of animals has been of late so successfully cultivated, and a few of the laws which govern them ascertained. It has been found that similar climates however widely separated from each other, are inhabited by similar animals, or animals of similar habits. Thus it is that the Himalaya mountains of Asia, which rise from the plains of the torrid zone through every belt of climate, to regions of perpetual snow, have representatives of almost every living class of creatures. This is of course considerably modified by the character of the surrounding country. If the zones of climate follow closely on each other, each becomes variegated by the encroachments of the productions of those above and below; the nature also of the soil considerably modifies it, such as hill or plain or swamp. But there are phenomena regarding the distribution of animals which at present seem inexplicable, such is the congregation of peculiar classes of animals in particular districts, beyond which they may almost be said to be extinct, a remarkable instance of which is to be found in the zoology of New South Wales. 
The knowledge of the distribution of animals may be of importance in another point of view, as affording collateral assistance to the Geologist in determining the character of the mutations of the earth. For as at the present time similar climates, however distant, however much isolated from each other, are peopled by similar creatures, so probably it has ever been; and this would seem to point to a period or periods when they were universally diffused: a diffusion which subsequent geological changes have very remarkably deranged. If all animated creation ever existed at any one epoch, the climate and condition of the earth's surface must have been so peculiar, that we can form no idea of them at the present time. While the geologists thus look to Natural History for assistance in solving some of their obscure problems, the Naturalists must in turn look to Geology for assistance in deciphering the system which nature has followed in forming her productions. In the existing races of beings there are many wide chasms which divide creation into irregular masses, which have hitherto defied all attempts at successful classification. But geologists are daily discovering extinct forms, which are filling up the vacancies, and which eventually may unite creation into an harmonious whole.

The Zoophytes at present existing on our shores are small and fragile when compared 
with those of warmer climates; yet the limestone of Devon and the slate rocks of Cornwall contain the remains of specimens, which for size and beauty might have vied with any now existing. Though the Cornish species are small, yet many of them are exceedingly elegant, and seem peculiarly fitted to invite attention. To myself the investigation it has been rather the amusement of leisure hours and pleasurable excursions on the water, than a study; had it however, been otherwise the pleasure derived from it would more than have compensated for any difficulties that could have occurred. It has been a source of health, innocent amusement and pleasure, and will be so to all who study nature where she is to be found; abroad rather than in the closet. As Cornwall, from its form has a very great extent of sea coast, some species have probably escaped detection; but as it is to be hoped that the number of observers will now be increased, these will soon be found, and where there is any doubt or difficulty, I shall esteem it a favour to be allowed to inspect such specimens, as well for my own, as for the benefit of others.

Penzance, August, 1844. 


\section{INTRODUCTION.}

The general form of most of the Zoophytes found in the British seas so exactly resembles that of plants, that it cannot be a matter of surprise that they were formerly thought to be marine vegetables. Even at the present time, when their natures are so well understood, the idea of vegetability is always associated with their appearances; and to a person not previously acquainted with the subject, the calling them animals would be revolutionizing all preconceived opinions; yet animals they unquestionably are. The first person who distinctly advocated this view of the question was Peyssonnel; his communications, however, to the Academy of Paris were received with so much distrust, that the Society never thought them worthy a place in their Transactions; and Reaumur, who read them, even deemed it necessary to conceal the author's name to shield him from that ridicule and contempt which such opinions were thought likely to create.* Under such circumstances, Peyssonnel's views lay for a long time neglected, and were finally forgotten. After a considerable lapse of time, Trembly brought back the attention of natura-

* He communicated his views to the French Academy in 1727, and they lay neglected till 1756, when, highly displeased with that body, he published them in the 'Transactions of the Royal Society.-Traite du Corail. 
lists to the subject by the publication of his remarkable experiments on the fresh water polypes; then Reaumur, recollecting Peyssonnel's papers, examined the subject for himself, and to compensate for his former caution adrocated them with boldness. But though he did it with great eloquence and ability, yet they were considered so extraordinary that they again sunk into oblivion, till Ellis, with the hand of a master brought the whole subject clearly and convincingly to light. Ellis after a great deal of research and patient investigation, published his celebrated "Essay on Corallines," in which he placed their animal characters on so firm a foundation, that they have ever since withstood the power of all assailants. He met, however, with upposition as powerful as it was fruitless; for though all the most eminent men of his day opposed him, yet his superior knowledge of the subject placed them entirely within his power. The most influential of those who differed from him was Linnzus, who at that time was in the zenith of his fame, and from whose decision there was no appeal; yet from Ellis' reasonings, he altered his opinions several times $\mathrm{He}$ at first considered them to be purely vegetable, but afterwards thought the horny species might partake both of the animal and vegetable natures. On this subject his views were highly poetical; "Zoophyta" he says in a letter to Ellis, "are constructed very differently, living by a mere vegetable life, and are increased every year under their bark, like trees, as appears from the annual rings in a section of the trunk of the Gorgonia. They are therefore vegetables, with flowers like small animals, which you have most beautifully delineated. All sub-marine plants are nourished 
by pores, not by roots, as we learn from Fuci. As Zoophytes, are, many of them covered with a stony coat, the Creator has been pleased that they should receive nourishment by their naked flowers. He has fumished each with a pore, which we call a mouth. All living beings enjoy some motion. The Zoophytes mostly live in the perfectly undisturbed aloyss of the ocean, they cannot therefore partake of that motion which trees and herbs receive from the agitation of the air. Hence the Creator has granted them a nervous system, that they may spontaneously move at pleasure." Ellis, however, was not to be shaken, he still retained his previous opinions, which, with the exception of those on the calcareous Corallines, are those now received as true. As these points will be considered when the different orders pass in review, it will not be necessary particularly to notice them here; but a careful examination of the observations scattered through the following pages will certainly convince the student of the truth of Ellis' views, however plant-like the productions may seem.

The system of arrangement which has been followed is the one proposed by Dr. G. Johnston in his work on British Zoophytes. In principle it is certainly more natural than any hitherto proposed, though it is open to a few objections. By making a polype to be an essential character of the Class, it thereby excludes some animals of still lower station, which by former Authors were united together. In the systems of Linnæus, Cuvier and many others the calcareous Corallines and Sponges are arranged with the true Corals, but in Jolinston's they are excluded. The calcareous Corallines are, however, now generally admitted to be purely vegetable; but though of late, some doubt has been expressed about the 
animal nature of the sponges there are sufficient grounds for considering them animals and as belonging to this class, and they are omitted here only from a desire of further investigation.

The British polypous Zoophytes naturally divide themselves into two grand divisions or sub-classes; the first embraces the radiated form, in which the body is contractile in every part with but a single aperture. This division contains three minor ones, or orders, the $\boldsymbol{H} y$ droida, Asteroida, and Helianthoida. The second division contains the Molluscan Zoophytes, in which the body is non-contractile, non-symmetrical, with two apertures. It has only one order, the Ascidioida which is very closely allied to the Mollusca tunicata. In the Hydroida the tentacula are tuberculated, and the stomach a mere depression made in the granular mass without any particular organization, and the horny sheath which is not found in all the genera, is external. In the Asteroida, the tentacula are eight in number and fringed; the solid parts when present, are all internal; and the external surface is always marked with eight rayed depressions. The Helianthoid having for its type the common Anemone, need hardly be refered to now. In the second sub-class there is a considerable advance in the complication of the polype. In the orders of the first division, the tentacula are prehensile and used only for capturing prey; in those of the second, they are clothed with vibratile cilia and are chiefiy subservient to respiration. In the first three crders, the polypes are comparatively sluggish, in the last they are remarkable for the rapidity of their actions.

Though these productions are low in the scale of being, and the polypes for the most part 
enclosed in horny or calcareous cases, yet they do not grow indiscriminately in any situation, but exercise a faculty of selection. This is very different from the selection of soils by plants, which imbibe their nourishment through their roots; for though rooted, all nourishment in these creatures is taken through the polype mouths. Among the Hydroida the Sea Beard, (Antennularia antennina) prefers oysters and other bivalves, but is also found on stones and sand; the form of the whole varying according to the locality. The Sea Oak, (Sertularia pumila) prefers the fronds of fuci growing near the tide marks, or the declivities of rocks in sheltered situations; the Sea Threads, the fronds of the larger fuci and the margins of pools, but they have been found abundantly on the fins of a shark; the Sea Bristles, dead muscle shells and horny corallines. This is the case also with the Sea Anemonies, but as they are naked and locomotive it is not so much a matter of surprise. Some species prefer one locality, and others another; some the smaller fuci, and others the larger; but the situations sometimes selected are exceedingly curious; thus the small climbing Coralline (Campanularia volubulis,) has a prediliction for the antennæe of crabs, where it can enjoy the advantages of locomotion in catching its prey.

This power of selection is also to be found in the Ascidian Zoophytes; thus the Flustra lineata prefers flat stones between tide marks, while the Membranipora Peachii most commonly selects a dead muscle valve and sometimes the dead oyster and great Pinna; the purple Tubulipora ( $\mathbf{T}$. Serpens) prefers corallines, while the Sea Mat (Flusira membrunacea) always encrusts the frond of the great sea weed (Laminaria digi- 
tata.) This is the case with all and their peculiar habitats will be noticed when speaking of each species. This selection of situations, however is a physiological one, rather than one which may be supposed to be the result of any intelligence in the animals themselves. For in the same situations of climate and depth of water, the same species will frequently grow on any substances provided there are similarities of surface. This is however considerably modified by collateral circumstances, such as the power to absorb and radiate heat and the durability of the substances on which they grow. Thus for instance the Caryophyllia Smithii most commonly selects for itself the moderately rough surfaces of stones, yet it has been repeatedly found in a young state on the lobes of Alcyonium digilatum, and on the stems of fuci, but in such situations it never attains a full size. The young of all the species will take root and grow for a short time, in situations which afterwards appear to be destructive to them. Those ova therefore which fix themselves in unfavourable situations perish, while others more favourably situated thrive and grow to perfection; but still it remains a mattel for speculation, why one kind of locality should be more favourable to one species than to another, since they derive no nutriment from the root.

It is a generally received opinion, that $\mathrm{Zoo-}$ phytes do not inhabit the depths of the occan, but are confined to shallow water and to districis surrounding the shores. The depths to which the coral reefs descend in the Lagoon islands is not considered a contradiction to this opinion, since they are supposed to owe their position to subsidences, in the same manner that the corals in the hills of those islands are placed there by 
elevations, effected posterior to their formation. The experience lerived from observations made on the Cornish Coast, can of course be but of little value, either as contradictory or confirmatory of such an opinion; yet it is proper to state that Zoophytes of all the orders to be described in the following pages have been procured from about sixty fathoms water. Though they, therefore, may not extend to any great depth, yet they are certainly not confined to thirty fathoms of water as has been supposed. Algæ, however, are never found on the stones drawn from more than twenty five fathoms, on any part of our coast.

In the following pages the term polypidom is very frequently used, but it is synonimous with polypier of continental Naturalists, and as only a convenient mode of expression for the solid parts of Zoophytes, such for instance as the horny parts of Sertularice and the solid axis of Gorgonia; beside this, no terms are used, which require any explanation. 



\title{
CORNISH FAUNA.
}

\author{
$\rightarrow \rightarrow 0+\cdots$ \\ CORNISH ZOOPHYTES.
}

SUB CLASS I.

\section{RADIATED ZOOPIIYTES.}

Body contractile in every part, symmetrical; mouth and anus one; gemmiparous and oviparous.

\section{ORDER I.}

\section{HYDROIDA.}

This, the first order of Zooyhytes, is very commonly dis. tributed on all parts of our coast from the tide marks to mid-channel; and the individual species are of such delicate and elegant shapes, as seem peculiarly fitted to invite attention and study. The outward forms vary from a single stem to the bushy appearance of the Ostrich featber or the Squirrel's tail; and the examination of their minate structure and economy shows an equal variation which adds greatly to the pleasure of their study. The arrangement followed in this essay, is based on the character of the animal or polype and is in some measure independent of the form and character of the hard parts or polypidom. Its character is : "Polypes compound, rarely single and naked, the mouth encircled with roughish filiform tentacula; stnmach without proper parietes : intestine none; anus none; reproductive gemmules pullulating from the body, and naked or contained in external vesicles. Polypidoms horny, fistular, more or less phyioidal, fixed, external." When the polypidom is present, it is always external and horny; but there are several species belonging to it which have none; and these are called Naked Hydroida. of the naked species, which inhabit fresh water, I have hitberto found none in Cornwall; though probably a more extended search may be successful, as the Hydra viridis has been found in Devon by Turton.

It was on these naked creatures that Trembly made his remarkable experiments, by which it was proved that they 
are so tenacious of life, as to be incapable of destruction by mutilation. When a head is severed from a body, the litter acquires a new head, and the head a new body. The head, or even the whole body, of one may be grafted on the body of another; or they may be divided into a multitude of parts and each will become a new body and a perfect animal. They may even be turned inside out, or slit up and extended as a meinbrane, without much apparent injury.

\section{Per damna, per cæedes, ab ipso}

Ducit opes animumque ferro.

When these experiments were first made public, they exciced, as they well might, the wonder of the world, nor do they now cease to astonish us, though made familiar by finding a place in most elementary works on Natural History and Natural Theology. Though the polypes of the sheathed or horny genera are incapable of undergoing such remarkable changes, yet the same disposition pervades the whole orter. If for instance, the Sea Oak (Sertularia pumila) or the Great-tooth Coralline (S. polyzonias) be allowed to remain in impure water for a few days, their heads and tentacula will frequently drop off and the polypes shrink into the cells; but, afterwards if the water be frequently renewed, a new head and tentacula will soon be formed. At first the new parts differ in colour from the older portions, but this difference in a very short time is entirely lost, although the new tentacula are rarely equal in number to the old ones: a circumstance that explains the variety assigned by different authors to the same species. In the Laomedea geniculata, for instance, I have counted in different specimens, 11, 19, 20 up to 29 tentacula, so that no reliance can be placed on them in determining the species.

In their actions, these animals are comparatively sluggish; and in struciure present, perhaps, the lowest form of organized animal existence. When examined under a microscope, not a single fibre is discovered by which their various actions can be supposed to be performed; but they appear to be composed entirely of minute distinct granules, each of which seems to possess a power of indepondent vitality. The impressions which produce the motions of the tentacula and body appear to be communicated from granule to granule chiefly by contact. The animal seems to be a simple granular pulp; into which a central depression is formed, which performs the office of a stomach, the nutriment being conveyed through the mass by imbibition, and the refuse or excrementary part ejected through the same orifice by which it is taken in. That the nutriment is conveyed by imbibition appears from the fact, that the colour of the 
polype depends on the colour of the food, and that those granules which are nearest the gastric surface are the first to change and so in gradation from the stomach to the external surface.* There appears to be no anatomical difference between the granules of one part of the body and another; for if the animal be turned inside out, the ontside will perform the function of digestion as perfectly as the original gastric surface, and the young will frequently sprout from the tentacula as well as from other parts of the body.

The horny or sheathed Genera vary a great deal in form, density, and the elaboration of their various parts, and have a very graceful appearence. Their form is more or less arborescent, and through their centres runs a granular pulp, which terminates, at the extremities of the branches, in polypes, which are snodifications of the pulp and formed from it. In the Hermia the sheath is nearly rudimentary, and forms an imperfect covering for the upper part of the pulp; in the Tubularia the polypes always protrude beyond the tubes, which cover the pulp; in the Thoce, Sertularia, Plumularioe, Campanulario, \& c . the polypes are furnished with cells, into which they retire either from satiety, alarm, or for rest. In some the cells are sessile, in others on ringed footstalks; they are cup shaped and arranged in one or two rows on the stems or branches. At certain seasons of the year, more especially about summer and autumn, but differing in different species, there are other larger cells formed, which are the ovarian vesicles, which drop off as soon as the ova or gemmules are perfected.

The mode of reproduction varies, not only in the different genera, but in the same under different circumstances. In the naked Hydroida the young sprout from the sides of the parent as perfectly formed animals, exercising the functions of independent life, even before they hecome separated. The young after remaining attached for some time, are thrown off by a vital process and the cicatrix becomes obliterated; so that no point can be observed on the old polype to indicate the former situation of the young. This form of reproduction sometimes takes place so rapidly, that the young even to the third or fourth generation have young before the first is separated from the parent; this gives the whole a very grotesquely branched appearance.

In the Sertulariada external ovarian vesicles are formed, which contain the reproductive gemmules. These are

* Trembly, Hist. des polypes p. 132. Roget's Bridgwater T'reatise, vol. 2, p. 77 and 78. Mag. of Zool, and Bot., vol. 1, p. 235. Note* 
mmediately distinguished from the polype cells, by the irregularity or their distribution, their greater size and by their being urn-shaped, having narrow bases by which they are attached to the polypidom, and contracted and terminal apertures through which the gemmules escape into the sea. These vesicles when first formed, are filled with a granular pulp of an uniform consistence; it soon, however, gets dark towards its centre and decreases in bulk, leaving the sides of the vesicle free; the pulp now looks like a central column running from the base to the neck, which is closed. The pulp still bears the appearance of the central pith or of a rudimentary polype, without a mark to indicate the formation of the gemmules; and up to this point the formation of the gemmules is alike in all the Sertulariada, though they differ in some measure afterwards. In the Laomedea geniculata the surface of the pulp soon gets furrowed and marked into indistinct globules with a darkish centre; and as developement goes on the gemmules get more distinct from each other, and the central dark spot of a deeper tint, more defined, and the part surrounding it more transparent, resembling the albuminous zone of the common egg; and they finally escape in this manner, till all the pulp contained in the vesicle has been converted into reproductive gemmules. In a kindred species, the L. gelatinosa a different method is pursued. In it the pulp fills the vesicle as in the case above, and the surface becomes marked and irregular, forming the first appearance of the future germs. They then appear more distinctly, and as if formed from the pulp itself; they rapidly get mure and more defined, and stand in relief from each other, remaining attached to the central placental column by minute umbilical cords. These cords getting nore and more attenuated are finally ruptured and the gemmules float at liberty within the cell. The vesicles being closed, the gemmules are hindered from escaping; but, whether from pressure or a vital process, the upper portiou rapidly gets thinner and more transparent and is finally ruptured, the gemmules then escaping into the surrounding fluid. Judging from a figure of Ellis' it would appear that a pulype is sometimes formed in these vesicles; and Jones in his "Outlines of the Animal Kingdom" has given a similar figure with an

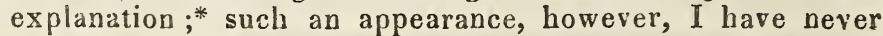
seen, though I have examined hundreds, or perhaps thousands of living specimens. The reproductive gemmules, which are now at liberty, are rapidly whirled about from place to place, stopping occasionally as if in search of a situation on which to fix. The motions of these minute 
bodies are very interesting and are produced by minute vibratile cilia which cover their surfaces and are generally in rapid motion. By means of these cilia the gemmules revolve on their own axes from spot to spot, sometines with a rapid gliding motion, at others by sudden springs; then stopping, and again bounding away to other spots, changing, their forms from round to oval or irregular; but having found a situation on which to fix, they generally become oval. The time during which they remain free varies from a few hours to two days, depending on the collateral circumstances of the purity of the water, temperature, and the nature of the spot around which they move. These bodies are frequently called ova; but as they are neither ripened by fecundation nor enclosed in a special membrane, Mr. Hogg proposes to call them reproductive gemmules. After becoming once fixed, they are for ever after incapable of motion, and if they should be removed, rarely, if ever take root again. As soon as they are fixed, there grow from beneath numerous tubulous fibres, which serve as roots, by which a firmer hold is obtained; and in this state they are better enabled to withstand the violence of the waves. The upper portion of the gemmules gets elongated, the central pulp enlarged, and the first cell is formed.

Another mode of reproduction is frequently observed in the same genera. When a polypidom has been formed from a gemmule, the tubular fibres by which the polypidom is rooted frequently trail over a considerable extent of surface, and as they do so, get enlarged at short and irregular distances; which enlargements increase in an upward direction, till, first a stem, then a cell and finally a perfect polypidom is formed. This mode of reproduction is easily observed in the Sea-threads (Laomedea) so common on our shores throughout the year: the Podded Coralline, (Plumularia cristata,) is another elegant instance of the same thing.

This order then is capable of reproduction; 1st. By the young pullulating from the parent: 2ndly. By reproductive gemmules enclosed in external vesicles: 3rdly. By shooting from the tubular roots of existing polypidoms; and $4 \mathrm{thly}$, it is sometimes said to occur by division; as by the artificial division of the fresh water polypes. Some Authors * intimate that this last manner occurs also in the horny genera, but this I have never observed, and believe never to take place; for I have noted that if a branch be either cut off, or thrown off spontaneously, the utmost it appears to be capable of doing is to survive for a very sbort time.

* Jones' Auimal Kingdom, p. 47. Sect. 66. 
Many Physiologists consider that each polype of a polydom, is a distinct being, and consequently that each polypidon is a congeries of animals united by a common axis. Though it is not of much importance whether we deem this opinion right or not, yet it will be best to consider the whole as one compound being, and the polypes as so many mouths through which the nutrition is taken in. There is nothing more visionary in this multiplication of mouths, than in the multiplication of feet in worms. The number of polypes on a polypidom varies according to the species, age, luxuriance and innumerable other circumstances; but sometimes the number is so great as to fill the mind with astonishment, and the wonder is increased the more we consider it. In a specimen of Sertularia argentea of luxuriant growth, in $\mathrm{my}$ possession, eighteen inches high, there are five pinnæ in a whorl, about fourteen whirls in an inch, and about thirty cells on each pinna, making the polypidom to contain the enormuus number of 37800 individual polypes in the space of a foot and half.

There is but little community of feeling existing between the different polypes of the polypidom; nor can it, I think, be expected from the nature of their internal structure. No nervous system has yet been discovered, and from the simplicity of their organization, no such discovery, is likely to take place. An impression to be felt by more than one polype, must be somewhat roughly communicated, since it is probable, that impressions are communicated chiefly by the contact of the granules.

It is generally allowed, however, that there is a community of nourishment, and no one, who has watched these animals, will call it in question. If a Sertularia be taken, and one only of its polypes be fed, nourishment is evidently supplied to all the rest and to the central pulp, which according to Grant* is furnished with a central canal, through which the nutrient matter is conveyed. The tentacula like the body, are contractile in every part, and are tuberculated; the tubercles being circularly arranged. Grant is evidently in error when he says that the tentacula are ciliated, for after many microscopic examinations on the majority of the Cornish species, I have never detected cilia in a single instance, and Dr. Johnston, a good authority, is of the same opinion. The mouth is also capable of a great deal of elongation and contraction, sometimes being conoidal and at others flat; so that at different times the polypes present a great diversity of form.

* Outlines of Comp. Anat., p. 13. 
The mode of growth and the nature of the sheaths or horny envelopes, have been matters of curious speculation; and to the present time are by no means settled points. When a seed or gemmule has become fixed, in the manner described above, and the roots thrown out from the base; the central pulp and its horny envelope become elongated superiorly. Taking the Laomedea geniculata, as an example, the central pulp of the gemmule becomes the pith; and after it has been elongated for a short distance, a lateral enlargement or rather elongation, takes place in the central pith, with a correspondent enlargement of the horny investment; this increases in length till it has become as long as the usual pedicle of the cell; at its termination it then becomes enlarged and bulbous, and the pedicle acquires a shrivelled appearance, which proves afterwards to mark the rudiments of the rings of the cell stalks. In a very short time the bulbous termination acquires a deeper tint towards its centre, and becomes lighter towards the circumference. At first the central shade is slight and indistinct, but soon becomes darker and more defined. As this condensation or organization goes on the pulp gets much more transparent towards its circumfereace, is drawn towards the central condensation and leaves behind it a transparent horny covering; and during this stage, it is very common to observe the senitransparent circumference of the pulp drawn into transverse folds, as if they were produced by a force acting towards the centre. In this way the pulp of the future polype is separated from the sheath. This being effected, the pulp acquires a serrated edge superiorly, and gets contracted inferiorly into the shape of the perfect polype. The serrations on the superior surface advance, and the tentacula are elaborated from them and folded on each other. Up to this point the cell is closed, and the polype excluded from any contact with the water. The superior portion of the horny sheath now gets thin, but not from pressure, as the polype is not in contact with it; and finally gives way about its centre and falls in, so as to give the cavity a fuonel-shaped opening. The polype now feels the influence of the surrounding water, and immediately springs into active life, using its tentacula and capturing il: prey as readily as the older ones. The funnel-shaped opening to the cell soon disappears and the differences which constiute the specific characters are formed. The stem is elongated in a similar manner; the pulp advances at one time the length of the articulations and stops for a short time, in the smaller kinds, till the cells and polypes are somewhat periected; but in the larger and more luxuriant species this can hardly be distinctly noted, as the growth of several inches sonetimes takes place in a very limited time. In the S. pulyzonias, 
I liave some reasnn to believe that a large specimen can bo formed under favorable circumstances, in the course of fourteen days. In the smaller species, a transient cessation of growth takes place at the various septa; at these points the pulp gets enlarged, and in the Sea Oak, S. pumila, where the two cells and stem are formed simultaneously, it appears as one very great enlargement, At first this enlargement of the pulp is undistinguished by parts or markings, which is however but of short duration, for three dark points appear on the pulp indicating the situations of the central pith with a polype on either side. The concentration or organization proceeds from below upwards, and the dark spots become more and more defined and separated from each other, the formation of the polype and cell being as described above. The extremities of the pinnze and trunk are closed during growth, and not open, as some authorities have stated." The growth certainly takes place rapidly, and chiefly about summer and autumn. In a specimen of the Sertularia argentea, now before me, a shoot of six inches has taken place, which is of a pure silvery white, while the lower and older portion is of a light brown colour. On a cross section of the stem of the new part, the horny sheath was found to be of equal consistence throughout, and very delicately spongy or cellular; in a cross section of the older stem the texture was not so elastically spongy, but harder and firmer, more especially towards the inner circumference of the ring, where there was a brown zone occupying nearly one half the diameter, as if a solid material had been deposited in the intercellular substance, or the cells had been more closely pressed together. As another instance out of many, of the rapidity of growth in these creatures, in a specimen of the compound variety of the great tooth Coralline, (S. polyzonias) about eight inches bigh, an egg of the Rough Hound, (Squalus canicula) has been deposited, and by its tendrils bas twined round the branches and bound them into one large clump; through the folds however fresh shoots bave sprung out in such great abundance as completely to hide the ovum from sight, unless the branches are first turned aside. On examining the ovum no advancement in developement had taken place; the cicatricula having the same appearance as those taken from the animal. From this specimen being taken at the time at which the fish were depositing their ova, it is probable, that it had not long been shed. In another instance, several very good specimens of the same Coralline mixed with Plumularia cristata and $\boldsymbol{P}$. falcata were growing on the case, but its contents had escaped. I

* Jones' Ontliue of the Animal Kingdom, p. 47. Grant, \&c. 
once found the $P$. Catherina growing on the bottom of a vessel in great abundance, after she had lain at Fowey harbour for a few months. The finest specimens of the L. Geniculata I have ever seen, were on the dorsal and caudal fins of the Picked dog-fish ( $\$$. Acanthias.) These and many other examples, tend to prove that these creatures are of quick growth.

The greatest number of the species of this order appear to be annual; very few, apparently surviving to the second year. Those growing near tide marks, cannot well be otherwise, for they soon become so completely encrusted with conferva and sponges, that the apertures of many of the cells are closed, and most of the others partially so, thus inclosing the polype and preventing access to the water. Beside this the Sea Oak and Sea Threads, the former of which is frequently infested with Entomastraca, in different stages of developement, grow on the fronds of sea weed, which are liable to be washed off by every storm. This is frequently the case, when the waves of the Atlantic roll heavily and furiously in, uprooting every thing in their course; yet after a few weeks of fine weather, specimens will be frequently found, even in fructification. The Sea threads, so common on all our shores, are to be found in the winter and spring, only in sheltered situations and beneath stones, but in the summer and autumn, on most of the weeds about low water mark, especially the Laminaria digitata. The larger kind appear to be of a similar nature; the Sertularia polyzonias, rugosa, abietina, Plumularia falcala, frutescens, cristata, \&c., are more abundant about summer and autumn than at any other parts of the year, though this probably depends on the weather; for if the winter and spring be fine they may be procured as good as at any other season. In the summer and autumn the Pinna Ingens is almost always covered with different kinds of Coralline, while in autumn it is commonly bare.

As the polypidom increases in age, the horny sheath of the branches and pinna gets firmer and more condensed; and then falls off. Thus it is that in some species the lower branches are always wanting; which is the case with the Bottle brush Coralline, Thuiaria thrja, and less so with most of the other branched species. This does not depend on the violence of the waves, though that no doubt effects a great deal, but is rather the result of an action taking place in the animal itself. In a branch about to be thrown off, the polypes first get inactive and retire to their cells, the central pulps get paler, more transparent, and unhealthy down as far as where the branch joins the sten; at which point there is a well defined line of demarcation 
formed, and at which the branch is finally thrown off. From the regularity of the process by which this is effected, the well defined scar left behind, and the central pith not being exposed, there is but little doubt left on my mind that each branch is thrown off by a vital process, similar to sluughing in animals, or the shedding of leaves in trees, and is not washed off accidentally by the sea. That very stout and rigid species the Sertularia nigra is exposed to the same violence, rendered more effective by its rigidity, and yet is not liable to have its pinnæ destroyed in a similar manner; and it is not unfrequently the case that in this last species the pinnæ are torn or twister off at various lengths, but such cases are not at all like the loss in the Th. thuja or $T$. articulata. The terminations of the stem and pinnæ are said to be open, during growth, which, however, does not appear to be the case; but if care be not taken to keep the specimens healthfully alive, or if they should be placed in fresh water, these parts from being young and delicately formed, readily rupture and the granular pulp is forced through the apertures. To such an ezient is this sometimes the case, that through the whole polypidom scarcely a trace of the pulp remains. This seems to arise from the irritability of the horny sheath, for that it is irritable there is sufficient proof.

There is an opinion entertained by some physiologists, that the external horny sheath is extravascular and consequently not endowed with vitality. It is considered by them as an exudation from the granular pulp. To this, however, my observations do not enable me to agree. Their mode of growth, the formation of their cells, and the manner in which they cast their branches tend against such a conclusion. In the formation of the cells, their apertures are always closed at first, and the polypes fully developed before they are opened; the polypes, in this enclosed state, do not press against the upper part of the horny covering, but lie towards the centre of the cell, yet the upper portion gets thinner and finally opens about the middle and falls in, in the form of a funnel. If this part was ruptured by the pressure from within, the torn margins would have been forced outwards, rather than have been inverted as is always the case. This mode of opening a cell is nearly alike in all the genera, yet they all afterwards assume their specific differences-differences so remarkable and constant as to leave no doubt but that they are the result rather of specific actions than of an accident. The peduncles of the cells of the Canipanularice are naturally but ringed at intervals, yet the animal possess a power to corrugate them throughout their whole extent, and does it at one time and not at another. When the extrenities 
of the pinnæe and stems are ruptured, the central pulp is always partially, and frequently wholly expelled. How can these phenomena be satisfactorily explained, but by supposing the existence of irritability and pressure in the sheath? I have never obtained traces of vascularity, but different sections of the trunk prove that some kind of action is going on there. If a cross section of a stem be taken from a young part, it will be found of light texture and of equal consistence throughont; if lower, to be harder and darker, especially towards its inner margin, and so in gradation to the roots, where it will be found of a hard and somewhat brittle consistence throughout. The younger parts may be bent with safety, while the older portions are more rigid and can be bent only at the risk of breaking. From these facts, it appears to be the most philosophic to consider the polypidom as endowed with vitality and as forming with the polypes and pulp the entire-animal.

Several species that grow near low water mark, will sometimes emit sparks of light when gently agitated, and this is greatly increased, if the water be gently heated. This is frequently the case with Sertularia pumila, and appears to arise from minute Entomastraca and Nacalephce which so constantly infest them.

'The order is divided into three Families which contain eleren Genera; and examples of each, except the fresh water polype, are common on all parts of our coast. Indeed so rich are we in these beautiful productions, that the majority of those recognized as British are to be found in our seas. The Generic differences, will be found at large in their proper places in the following pages, where their species are described, and need not therefore be given here. A summary of the whole will be found at the end, drawn up without reference to the polype, to suit the convenience of those who are not intimately acquainted with the subject.

\section{TUBULARIAD $\mathbb{E}$.}

Polypes gemmiparous, the gemmules naked, pullulating from the base of the tentacula.

\section{CORYNE, Gaertner.}

Generic Character: Polypes fixed, single, naked, cylindrical or claviform, but contractile, the head with scattered filiform smooth tentacula, mouth none?

C. SQUAMATA. Body more or less clavate; the tentacula shorter than the body.

Tubularia affinis, Turton's Lin., vol. 4, p. 668. Stewart's Elem., vol. 2, p. 438. Coryne Squamata, Fleming's Brit. An., p. 553. C. Multicornis, Templeton in Mag. of Nat. Hist., vol. 9, p. 419. Johnston's Brit. Zooph., p. 109, pl. 2. 
Hab. On sea weed and old shells, about low water mark. Gorran Haven, common; Polperro, rather rare; Talland sand-bay, and Looe.

This species is gregarious in its habit, growing on fuci and attaining the height of two to eight lines. It is attached by a narrow base; in young specimens, the appearance is like that of a common hydra, with the tentacula irregularly arranged on various parts of the body; in older specimens the base is prolonged into a narrow footstalk, with the tentacula at the summit. The tentacula are filiform and vary from five to twenty in number. The colour is redlish with occasionally deeper spots about the tentacula and base. It is sometimes found on the under surface of stones within low water mark.

HERMIA, Johnston.

Generic Character: Polype fixed, sheathed in a this horny membrane, clavate or branched and subphytoidal, the apices of the branches clubbed, and furnished with scattered glandular tentacula; mo mouth.

H. GLANDULOSA. The branches in pairs, and the tentacula shorter than the enlarged heads of the branches.

Tubularia Coryna, Turton's Linnæus, vol. 4, page 668. Stewart's Elements of Natural History, vol. 2, p. 438. Coryne Glandulosa, Fleming's Brit. An., p. 553. Johnston in Mag. Nat. Hist., vol. 5, p. 631, fig. 110. Hermia Glandulosa, Johnston's British Zoophytes, p. 111, fig. at page 109, and pl. 4 , figs. 1 and 2.

Hab. Fonnd under stones about low water mark in sheltered situations; not uncommon. Polperro, Gorran, Whitsand-bay.

These polypes have a very singular appearance. The head is large and irregular, and along its sides the tentacula stand out in an irregnlar manner. The tentacula are club shaped, with a rounded extremity. Inferiorly the pulp is enclosed in a horny membranous sheath, but the polype-heads and neck are naked or covered with but a very slight continuation of the horny envelope. In its actions it is very sluggish; but it has a power of moving each of the tentacula independent of the others or all together. The polypidom is confervoid, horny, wrinkled and somewhat dichotomously branched, and varies in height to about an inch. It is not very uncommon in particular localities throughout our southern shores. As at Giggen, Polperro; Vault-beach, Gorran; and in particular spots in Whitsand-bay. It prefers the under surface of stones about low water mark; and pools between tide marks in sheltered situations where small algæ abound. 
TUBULARIA, Linnæus.

Generic Chatacter: Polypidom rooted, more or less planto like, horny, tubular; no cells. The polypes protruding at the end of the branches, and not retractile. The head is crested with one or two rows of tentacula.

* Tubes undivided.

OATEN-PIPE CORALLINE. Tubularia Indivisa. Tubes clustered, simple, cylindrical, narrowed and interworen at the base. The head is clustered with one or two rows of tentacula.

Adianti aurei minimi facie planta Marina. Ray's Synop., vol. 1, p. 31., no. 4. Remarkable sea plant, Lhwyd's Phil. Trans, Tubular Coralline, like oaten pipes, Ellis' Corallines, p. 31, pl. 16, fig. c. Tubularia indivisa, Lamourous's Cor. Flex., p. 230. Blumenbach's Man., p. 2\%2. Turton's Lin., vol. 4, p. 666. Stewart's Elèm., vol. 2, p. 437. Flem. Brit. An., p. 552. Johnston's British Zoophytes, p. 113, pl. 3, figs. 1 and 2. Solander and Ellis' Zooph., p. 31.

Hab. Attached to stones from deep water. Polperro, West Combe, Lansallos; rare. On the Gwinges rocks, near Mevagissey, common, Mr Peach.

This, in particular situations, is very common, as on the Grwinges rocks near Gorran and the neighbourhood, and in deep water about three miles from the shore, Polperro. The tubes are simple from the roots to the terminations, The height of the tubes varies from two to fourteen inches, and they are about the tenth of an inch in diameter. At the roots they are frequently twisted and convoluted on each other, but they soon rise simple and undivided. The centre is filled with a soft granular pulp which passes up each tube and terminates in the polypes. The poly pe beads are red and incapable of being withdrawn into the tubes. The mouth is produced into a conical elevation, and around is a circle of red tentacula; inferior to this circle is another in which the tentacula are much longer than in the one above. Below this last circle, are produced the reproductive gemmules. The young sometimes pullulate from this part, and when sepan rated from the parent, they travel to some other spot by means of their tentacula, tiil having selected a proper situation, they fix themselves by their base. From this spot they never afterwards move; but a horny ring is formed round the base, and increasing as the polypidom grows, forms the tubes of the perfect animal. Sometimes, a few specimens are found sparingly branched.

WINDPIPE CORALLINE. T. Larynx. Tubes clustered, ringed at intervals; polypes with a double row of tentacula. 
Fucus Dealensis fistulosus, Laryngæ similis. Ray's Synop., rol. 1. p. 39.. no. 3. Tubulous Coralline, wrinkled like the windpipe, Ellis' Corallines, p. 30, no. 1, pl. 16, fig. b. Tubularia Muscoides, Trarton's Lin., vol. 4, p. 667. Stewart's Ełem., vol. 2, p 438. Fleming's Brit. An,, p. 552. TubuJaria laryns, Ellis and Solander's Zooph., p. 31, no. 2. Johnston's Brit. Zooph., p. 115, pl. 3, fig. 3, pl. 4, figs. 3 and 5.

Hah. On shells and stones beyond low water mark, and on shells from deep water; common; at Talland sand-bay.

There are two varieties of this species, one branched and the other not. The branched variety gives off its branches ii a very irregular manner, and generally at an obtuse angle with the trunk. This is however liable to considerable variation and irregularity. The unbranched variety is generally found in clusters, interwoven at the base, and filiform. This species is distingnished from the last, in dried specimens, by the tubes being ringed at regular intervals, presenting the appearance of the windpipe of a bird; from which it derives its name larynx. In a recent state, the rings are visible by transmitted light. The polypes are naked, with two circles of tentacula. The head is light red, the tentacula are white, or white fringed with red. The reproductive gemmules rise from the base of the tentacula.

\section{** Tubes branched.}

T. RAMOSA. Tube single and regularly branched; alternate and ringed; the polypes with only a single row of tentacula.

Small ramified tubular Coralline, Ellis' Coral., p. 31, no. 3. pls. 16 and 17, fig. a A. Tubularia Ramosa, Ellis and Solander's Zooph., p. 32, no. 3. Turton's Lin., vol. 4, p. 666. Stawart's Elem., vol. 2, p. 43\%. Fleming's Brit. An., p. 552. Mag. Nat. Hist., vol. 1, p. 2\%8. Templeton in Mag. Nat. Hist., vol. 9, p. 466. Johnston's Brit. Zooph., p. 116.

Ilab. From deep water off the Dearman on the Pinna Ingens, common; and a little beyond low water mark, Polperro; Gorran, Miveach.

This Species may be distinguished from branched varieties of the preceding by the regularity with which the branches arise, in an alternate manner. It appears to be confounded with several species, especially with the branched variety of T. Larynx and the following, T. Ramea. In comparing the two together there will be but little chance of confusion; but otherwise, it may be difficult to distinguish between therm. 
This species is generally more branched than the branched variety of T. Larynx, and usually in an alternate manaer. The branches do not rise from the trunk at such an obtuse angle as in the last; the tubes are smaller, more dense, of a deeper colour, and do not present such decided rings as T. Larynx. The polype heads are red, month conical, with a single circle of tentacula. Ellis' figure in his "Essay on Corallines" is very good and characteristic.

T. RAMEA. Arborescent, stem and branches formed of agglutinated filiform tubes, irregularly branched. Polypes, with a single row of tentacula.

Tubularia Ramea, Johnston's Brit. Zooph, p. 117, pl. 5, figs. 1 and 2.

Hab. On Pinna Ingens, south of the Deadman point.

The appearence of this species is so remarkable, as to render a fair specimen difficult to be confounded with any other. It is very bushy and very closely resembles a miniature tree. I have a fine specimen from eight leagues off the Deadman point, eight inches high. It is very stont, rigid and of a dark brown colour. The chief branches and trunk are composed of many agglutinated tubes, which decrease in number as the branches divide; the ultimate or terminal branches are composed of a single tube with one or two annulations at the origin of each. I have not observed the polypos but they are said to have a single row of white tentacula. The routs are matted together like a coarse sponge.

\section{SERTULARIAD BE.}

Polypes gemmiparous, the gemmules enclosed in ovarian persistent vesicles, scattered on the polypidom.

\section{THOA, Lamouroux.}

Generic Character: Polypidoms rooted, arborescent; the stem composed of aggregated sub-parallel capillary tubes; the branches alternate, spreading bifarionsly; cells tubular, indistinct, alternate; ovarian vesicles irregularly scattered. Polypes hydraform, scarcely retractile within their ceils.

HERRING-BONE CORALLINE. T. Halecina. Cells oval, vasiform, contracted near the mouth; moutis subterminal and somewhat patulous.

Corallina scruposa pennata, cauliculis crassiusculis rigidis, Raii Synop., vol. 1, p. 36. Herring-bone Coralline, Wllis' Coral., p. 17, no. 15, pl. x. Sertularia halecina, Ellis and Solander's Zooplr., p. 46, no. 15. 'Turton's Lin., vol. 4, p. 678. Stewart's Elem., vol. 2, p. 442. Fleming's Brit. An., p. 542. Templeton in Mag. Nat. Hist., vol. 9, p. 4133. 
Thoa Halecina, L mouroux's Cor. Flex., p. 211. Johnston's Brit. Zooph., p. 119, pl. 6.

Hab. On stones and shells, especially the Pinna Ingens, from deep water west of the Eddystone to Falmouth; common.

This species grows to the height of eleven inches, and from four to eleven inches in breadth. In young specimens, the polypidom is of a light horn colour, which in the older turns to a dark brown. The polypidom is arborescent, much branched, and rooted by numerous fibres interwoven and matted with each other. The trunk is formed of numerous sub-parallel tubes agglutinated together. The branches are brown, and when dry rery brittle; they are irregularly given off; the pinnæ are alternate, and both erecto-patent. Here for the first time the polypes have cells, into which they can retire for shelter; they do not, however afford such complete shelter as in the following genera. The cells are alternate, tubnlar, bi-articulate and with plain apertures, The Ovarian vesicles are scattered over every part of the polypidom, but are most abundant about the axilla of the pinnæ; they are pedunculated, smooth, with a long neeks and edges round them like a jug.

T. MURICATA. Very rigid, irregularly branched, branches semi-erect and spreading; cells alternate, visible on the younger branches only; vesicle small, round, and prickly, cup shaped, with an even aperture, separated froin the siem by a joint.

Sertularia Muricata, Ellis and Solander's Zooph., p. 59, pl. 7, figs. 3 and 4. Turton's Lin., vol. 4, p. 68I. Stewart's Elem., vol. 2, p. 445. Laomedea Muricata, Lamouroux's Cor. Flex., p. 209. Thoa Muricata, Johnston's Brit. Zooph., p. 121, pl. vii., figs. 3, 4.

Hab. On a shell from deep water, off Mevagissey; rare.

This rare and stout species rises from a fibrous and spongy base to the height of three inches. It is very stiff, irregularly branched, of a light dull brown colour, and is composed of a great number of small tubes very irregularly twisted on each other. The branches are numerous, irregular tubular. The cells are minute and frequently absent, being destroyed by the action of the sea. The vesicles are clustered, round and beset with prickles.

\section{SERTULARIA, Linnæus.}

Generic Character: Polypidoms rooted, plant-like, variously branched, divisions or branches formed of a single tube, divided at regular intervals by imperfect septa; cells paired or arranged in two opposite rows, sessile, distinct 
and separated from the stem by a joint, short with everted apertures; vesicles scattered. Polypes hydraform.

\section{* Cells distinctly alternate.}

GREAT TOOTH CORALline. S. Polyzonias. Erect, subflexuous; cells ovate, with a wide somewhat uneven aperture; vesicles obovate, wrinkled across, the orifice contracted and plain.

Corallina minus ramosa, alterna vice denticulata. Muscus marinus denticulatus minor, denticellis alternis; Raii Synop., vol. 1, p. 35, no. 13. Great Tooth Coralline, Ellis' Coral., pl. 5, pl. 2, fig. a A., and pl. 38, fig. 1 A ; Sertularia polyzonias, Ellis and Solander's Zooph., p. 37, no. 3. Turton's Lin. vol, 4, p. 683. Blumenbach's Man., p. 273. Stewart's Elem., vol. 2, p. 447. Fleming's Brit. An., p. 54:. Templeton in Mag. Nat. Hist., vol. 9, p. 468. Johnston's Brit. Zooph., p. 122, pl.8, figs. 1, 2, and 3. Lamouroux's Cor. Flex., p. 190.

Hab. On fuci beyond low watěr mark, on stones and shells from deep water; common. Parasitical on Alsyonium digitatum, or dead man's hands, and other corallines; very common, from the Rame Head to the Lizard, and ten leagues from the shore.

There are two varieties of this species, both alike common; the first, where the stem is composed of a single tibre and sparingly branched, rarely exceeding two inches in height; the second, where the stem is composed of a number of tubes twisted on each other and growing to the height of six inches. In the last variety, the polypidom is erect, rigid, and rooted, with tubular fibres which are closely matted together. I have a fine specimen from deep water, growing in a large tuft, ten inches in height.

The following has also been considered a varity of this species, but is now allowed to be distinct.

ELLIS' CORALLINE. S. Ellisii. Climbing, flexuous; the cells urceolate, bulged at the base, with a four toothed rim; vesicles with the opening four-toothed.

Ellis' Corallines, p. 6, pl. 2, fig. b, B. Sertularia Ellisii, Johnsion's Brit, Zooph, p. 123.

Hab. On Ascidia with other corallines; rather rare.

This can be distinguished from the last by the stem heing more zigzag, the mouth of the cell more decidedly fourtoothed, and the whole more slender and climbing. T'Le vesicles are vasiform and surrounded with promincnt bauds, which give them a remarkable appearence. 
SNAIL-TREFOIL CORALLINE. S. Rugosa. Cells ovate, wrinkled transversely, the mouth narrow, with three or four small teeth on the rim. Ellis.

Snail-trefoil Coralline, Ellis' Coral., p. 26, no. 23, pl. 15, fig. a A. Sertularia Rugosa, Turton's Lin., vol. 4, p. 678. Ellis and Solander's Zooph., p. 52, no. 24. Stewart's Elem., vol. 2, p. 442. Fleming's Brit. An., p. 542. Templeton in Mag. Nat. Hist., vol. 9, p. 466. Johnston's Brit. Znoph., p. 12:3, pl. 8, figs, 4, 5, and 6. Clytia rugosa, Lamouroux's Cor. Flex., p. 204.

Hal. On the roots of fuci, sponges, \&c.; Lantivet bay.

This species is not common; but when found it is generally in large companies, shooting up from the trailing tubular roots of each other. It rarely exceeds an inch in height, is erect, and very sparingly branched. The cells are irregularly arranged, sometimes being alternate, and at others crowded together; it may, however, be immediately recognised by its remarkably wrinkled eells. The vesicles very closely resemble the cells, but are much larger and the apertures are three-toothed.

$$
\text { * *ells in pairs, opposite, or semi-alternate. }
$$

\section{LILY OR POMEGRANATE FLOWERING CORAL-}

LINE. S. Rosacea. Cells opposite, closely arranged, mouth entire, plain, and truncated; vesicles pear-shaped, with a very uneven mouth.

Lily or pomegranate flowering Coralline, Ellis' Cor., p. 8, no. 7, pl. 4, fig. a A. Dynamena Rosacea, Lamouroux's Cor. Flex., p. 178. Fleming's Brit. An., p. 544. Sertularia Rosacea, Ellis and Solander's Zooph., p. 39, no. 7. Turton's Lin., vol.4, p. 676. Stewart's Elem., vol. 2, p. 440. Johnston's Brit. Zoopl., p. 124, pl. ix., figs. 1 and 2.

Hab. On Pinna Ingens, from deep water off the Deadman point; rather rare; Gorran, Mr. Peach.

From one to two inches high. The colour of this species is of a delicate hurn or pale brown. It is slender, drooping, and rooted by numerous brown tubular fibres matted together. It is sparingly branched in a bifarious manner. The pinnæe are alternate, and but slightly smaller than the trunk. The trunk and pinnæ are divided into joints at short intervals; and each internode bears a pair of cells. The cells are opposite; their superior portions free and very divergent; their apertures slightly everted, even and unarmed, though sometimes gently waved and the external portions slightly pointed. The vesicles are sometimes abundant and arise from the base of the upper row of cells; they are pear shaped, 
and their upper part is remarkably furrowed and surrounded by numerous spines "like a coronet." All the vesicles are not alike ornamented by the spines, but the spines are always present, sometimes larye and at others small. Ellis appears to think that the coronated state of the vesicles, depends on the expulsion of the gemmules; but this is not always the case. In a specimen before me the gemmules, thongh ripe are not yet excluded, and the spines not only surround the upper edge of the vesicle, but are scattered over one third of the upper surface. Johnston says, "Pallas asserts that the comparison, as well as the figures of them in Ellis' work are inaccurate, a criticism the truth of which Ellis denies in his subsequent volume on Zoophytes:' many of those ovaries that $I$ have examined are unlike any representation of them I have yet seen, while others closely resemble the figures of Ellis and Johnston.

SEA OAK CORALLINE. S. Pumila. Cells opposite, approximated, shortly tubular, the top everted with an oblique somewhat mucronated aperture; vesicles ovate.

Corallina pumila repens, minus ramosa. Muscus coralloides pumilus, denticellis bijugis, Raii Synop., vol. 1, p, 3\%, no. 19. Corallina pumila erecta, ramosior. Muscus coralloides punilus ramosus, Raii Srnop., vol. 1, p. 37, no. 20, pl. 2, fig. 1. (not good). Sea Oak Coralline, Ellis' Cor., p. 9, pl. 5, fig. a A. Sertularia pumila, Ellis and Solander's Zooph., p. 40, no. 48. Turton's Lin., vol. 4, p. 676. Stewart's Elem., vol. 2, p. 441. Templeton in Mag. Nat. Hist., vol. 9, p. 468. Johnston's Brit. Zooph., p. $12 \delta$, pl. 9, figs. 3 and 4 . Dynamena pumila, Lamouroux's Cor. Fles., p. 179. Fleming's Brit. An., p. 544.

Hab. About low water mark on the shelving sides of rocks; common the whole length of the south coast.

Very common on the shelving sides of rocks and on fuci, especially Fucus serratus, near low water mark. It seems to prefer those rocks which have a sonthern aspect, though it does not confine itself exclusively to the sunth side, but seeks for shelter in the crevices and beneath the overhanging weed wherever it can be found, on rocks so situated. It is of a darkish brown colour, rarely exceeding an inch in height, sparingly branched and rooted by creeping tubular fibres, from which new polypidoms rise at irregular intervals. The cells are opposite, and closely approximated; they are hulged at the base, their apertures somewhat contracted and everted; and each pair is separated from the other by a joint. The vesicles are pear-shaped, with tubular apcrtures, and are attached to the base of the 
cells by short peduncles. In the summer and antumn they are plentifully produced on all parts of the polypidom. The polype is granular, with fourteen stout tentacula; and when in activity, protrudes itself about the length of the cell beyond the aperture. The life of this species can be but of short duration. When growing on fuci, it is destroyed by the waves tearing these fuci from the rocks; and when it fixes itself on the rocks, it soon becomes infested with minute sponges and convervæ which grow over the apertures of the cells and prevent the polypes from having access to the water; whereby they perish. It is also much infested with minute insects (entomastraca) of the genus Cyclops, which is probably the cause of the light so frequently given off when this species is gently struck while in the water.

SERTULARIA PINNATA. Cells opposite, tubular, the upper part free and divergent, with an even patulous aperture; vesicles obconical, trituberculate on the top.

Sertularia Pinnata, Johnston's Brit. Zooph., p. 127, pl. ix, fig. 5 and 6. Sertularia Fuscescens, Turton's Lin.. vol. 4, p. 677. Lamouroux's Cor. Flex., p. 195. Dynamena Pinnata, Fleming's Brit. An., p. 545.

Hab. "Oceanus ad Prom. Lacertæ, Cornubiæ," Pallas. I have not met with a specimen, and it is therefore called Cornish on the authority of Pallas.

BLACK CORALLINE. S. Nigra. Cells very nearly opposite, approximated, appressed, small ovato tubular, apertures even and not everted; vesicles like an unripe fig, with small contracted terminal apertures.

Sertularia Nigra, Turton's Lin., vol. 4, p. 676. Johnston's Brit. Zooph., p. 128, fig. 15, p. 129, and fig. 13, p. 119. Mantell's Wonders of Geology, vol. 2, p. 534. Dynamena Nigra, Fleming's Brit. An., p. 545.

Hab. Lizard point, Pallas; off Polperro and Deadman point; not uncommon.

This species varies from three to six inches and sometimes eren to eight inches in height. The trunk and pinnæ are stout, rigid, and divided into joints at regular intervals. The pinnæ arise from the trunk alternately, and very close to each other. The cells are arranged in a bi-serial manner, on the pinnæ and trunk; they are semialternate, crowded, and adnate or pressed against the polypidom; they are tubular, with even patulous apertures; on the lower part of the trunk they are generally absent, but are always to be found on the upper and newer portions. The vesicles, in shape, resembling unripe figs, are attached to the polypidom by 
elongated peduncles, which arise from the base of the cells. Their apertures are terminal, unarmed and contracted; when recent and living they are smooth, but are frequently marked, when preserved, with longitudinal furrows. This form of the vesicle is rarely observed except when it has arrived at perfection, but in a less advanced state the upper portion is flat, and the circumference irregularly lobulated. They only arise from the upper edge of the pinna, and are all turned to the same side of the fan of the polypidom. This species, as it is seen in collections, is of a dark or black-brown colour, from which it deriven its specific name; but to see it in all its beanty it must be examined in a living state and soon after it is taken from the sea; when instead of being black, it will be found of a beautiful and delicate pink, and in some instances of a deep arterial blood colour. It is the stoutest and most rigid of all our native Sertulariæ, but there are several others which exceed it in beauty and delicacy, Though not so generally diffused as many others, it is far from being uncommon in particular localities. Off the Deadnan-point it is found, though rarely; at a few miles west and north-west of the Eddystone lighthouse it is common, and from that locality I have obtained some exceedingly fine specimens, which, from January to May, have abounded in ovarian vesicles. It is firmly rooted to the stone on which it grows, by tubular matted fibres, of a deeper tint than the other parts. On the lower portion, the Campanularia dumosa is frequently abundant.

According to Johnston, Milne Edwards supposes there are two species confounded under this name. The species, however, that I have found in the Cornish waters is the same as that figured by Johnston at pages 119 and 129, though I have not observed the irregularity in the distribution of cells on the pinnæ, or the form of the apertures of those on the trunk, figured and noticed by him.

SEA TAMARISK. S. Tamarisca. Cells opposite, tubular; the upper half divergent, with a wide aperture, sinuated on the margin; vesicles oval, truncate, with two small points on the corners, and a tubulous month.

Sea Tamarisk, Ellis' Coral., p. 4, no. 1, pl. 1, fig. a A. Sertularia Tamarisca, Ellis and Solander, p. 36, no. 1. Turton's Lin., vol. 4, p. 696. Stewart's Elem., vol. 2, p. 441. Johnston's Brit. Zooph., p. 130, pl. x, figs. 2, 3, and 4. Lamouroux's Cor. Flex., p. 188, no. 313. Dynamena Tamarisca, Flemirg's Brit. An., p. 543.

Hab. On the Pinna Ingens, from deep water, rare.

The only locality in which this has been fornd is in deep water off Meragissey, and even thence only a few specimens 
have been procured. It varies in height from four to twelve inches, but the Cornish specimens did not exceed six. It is rather delicate, and of a semi-transparent horn colour inclining to pink when living, changing to a deeper and daller colour in dyin:. The branches, which are widely separated from each other, are given off alternately. The cells are opposite, pellucid, attached to the polypidom by the base, the upner half being free and divergent, and distributed in a biserial manner; their apertures are patulous, with two lateral tooth-like inequalities. The vesicles are unilateral and arise from the base of the upper row of cells; they are shortly pedunculated, stont, longitutinally furrowed, and their apertures are small and tubular. They vary in shape according to age. When young they are urn shaped with tubular apertures; a little older, the rim at the base of the neck becomes enlarged and sharp-odged, with two small horns; when old, the neck and mouth disappear after the ova have escaped, and the margin becomes irregularly festooned.

SEA FIR. S. Abielina. Cells very nearly opposite, tubular, slightly bellied at the base; mouth simple and unarmed; the upper half free : vesicles ovoid with a neck.

Corallina marina Abielis forma. Muscus marinus major argule denticulatis Raii Synop. Siirp., vol. 1, p. 35, no. 12 , Sea Fir, Ellis' Cor., p. 4, pl. 1, fig. b, B., no. 2. Dynamena Abietina, Fleming's Brit. An., p. 54.s. Sertularia Abietina, Ellis and Solander's Zooph,, p. 36, no. 2. Lamouroux's Cor. Flex., p. 186 and 187. Turton's Lin., vol. 4, p. 676. Blumenbach's Man., p. 273. Siewart's Elem vol. 2, p. 441. Templeton in Mag. Nat. Hist., vol. 9, p. 468. Johnston's Bril. Zooph., p. I30, pl. x., fig. 1, 1.

Hab. On stones, shells and Gorgonia verrucosa, common, from deep water. In the Fowey river, on stones and shells.

This species varies in height from four to eight inches, growing in great luxuriance on Pinnce, at from six to nine leagues south of the Deadman point; and less so near the shores, where it is generally in an injured state, having the branches and cells knocked oif by the violence of the waves. In a perfect state the polypidom is of a light brown colour, polished, compressed laterally, slightly bent, and has cells both on the branches and trunk. The branches which are about as large as the trunk, arise in an aliernate manner, and more closely together than in the last species. The cells are semi-alternate, bellied at the base, with contracted and everted apertures, and are attached only at the base, the upper portion being free and diverging. The resicles, which are $\mathrm{few}$ in number, small, and irregularly distributed, arise 


\section{3}

by short peduncles from between the cells, and have small sub-terminal apertures which are generally turned towards the trunk.

This species bears a general resemblance to the last, but differs in having a closer arrangement of the branches, the base bellied, aperture contracted, and in the semi-alternate distribution of the cells.

FERN CORALLINE. S. Filicula. Cells in the form of a Florence flask, opposite, a single one in the axilla of each pinna; vesicles pear-shaped, smooth at the aperture and shortly tubulous, entire.

Dynamena Filicula, Fleming's Brit. An., p. 544. Fern Coralline, Sertularia Filicula, Ellis and Solander's Zenph., p. 57, table 6, fig. c. C. Tarton's Lin., vol. 4, p. 681. Stewart's Elem., vol. 2, p. 445. Lamouroux's Cor. Flex., p. 188. Johnston's Brit. Zooph., p. 131, pl. 11.

Hab. On Fuci, rather rare. Talland sand bay, Polperro.

This species varies in height from one to four inches, is of a yellowish brown colour, zig-zag and spreading laterally. The branches are given off somewhat bifariously, but sometimes very irregularly. The trunk, and branches are divided at short intervals by imperfect septa. The pinnæ are numerous, and arise in an alternate manner, one from each internode. The cells, which are bellied at the base with plain everted apertures, are opposite and in single pairs on each internode, with a single cell in the hend of each pinna as it arises from the trunk. The resicles are pear shaped, arising from the upper part of the base of the cells by a short peduncle, and the apertures are contracted and tubular.

This species may be distinguished from all others by the single cell which stands in the axillre of all the pinna. In other respects it approaches very closely to the Great toothed Coralline.

SEA HAIR. S. Operculata. Cells opposite, larger above than below; mouth patulous, scarcely everted, the outer edge terminating in a long tooth with two lateral smaller ones, a joint above each pair; vesicles pedunculated, obovate.

Corallina muscosa denticulata procumbens, caule tenuissimo, denticellis ex adverso sitis. Raii Synop. Stirp., vol. 1, p. 36, no. 18. Sea Hair, Ellis' Corals, 8, no. 6, tab. 3, fig. b. B. Dynamena operculata, Fleming's Brit. An., p. 544. Lamouroux's Cor. Hlex., p. 196. Seriularia operculata, Ellis and Solander's Zooph,, p. 39, no. 6. Turton's Lin., vol. 4, p. 676. Stewart's Elem., vol.2, p. 411. 'Templeton 


\section{4}

in Mag. Nat. Hist., yol. 9, p. 468. Jobuston's Brit. Zooph., p. 132, pl. xi., fig. 2. 2.

Hab. On the stems of the larger fuci, common. Whitsand bay, Looe, Goran, Mevagissey, Veryan bay, Polperro, Alount's bay.

The name of Sea Hair, applied to this species, is very characteristic of its general appearance, and to an inaltentive observer it would pass for something of the kind, as it lies exposed on the shore. It grows plenifilly all round our rocky shores on the stalks of the larger sea weed, a little beyond low water mark. On the south eastern parts of our coast, it occurs most commonly as short, delicate hairlike fibres on the stalks of the Laminaria digitata, and rarely exceeding an inch and half in height; but frequently after a storm, clumps, as large as a child's fist, are washed ashore from deep water. Abont Mevagissey, Goran, and west of the Deadinan point in Veryan bay, it occurs in masses as large as a child's head, or even larger. Mr. Peach of Goran has some very fine specimens in his collection, and I have some equally fine, from the same neighbourhood. I have been informed that several years ago, many curiloads of this Zoophyte were drawn on shore in a trawl net at Mevagissey and sold as manure; whether this is true or not, it is certainly more abundant and finer there, than on any other part of our coast that I have examined. It is of a vandyke brown colour, very slender and eleganily waved. Its offshoots are numerous, alternate and of equal size to the first. It does not like the rest of the species of this genus, give off its branches from a continuuas irunk, but the offsets frequently become the continuations of the height of the polypidom. It is divided at short intervals by imperfect septa; the internodes join each oiber in straight lines, but in ronsequence of their being so slender, they yield to each other, and give the polypidom a zig'zag or genily wared appearence. The cells are opposite, in single pairs on each internode, and attached through the greater part of their extent; their apertures, are not everted like those of the others of this genus, but look upwards; the external edge of the aperiure is continued into a slender acule point, and has beside two large lateral teeih. The vesicles are irregularly (iistributed over the polypidom, of a long egg-form; the inferior portion is pedunculaied, the superior truncated with an operculam, and they are most plentifully produced from December to April. In the figure of this species given by Wllis in his essay on Corallines, the lateral teeth of the cells are omitled because the specimen was not " placed in a side view for the painter when it was drawn." 
SQUIRREL'S TAIL. S. Argentea. Polypidom spiry and waved; cells alternate, bulging at the base, and sharply pointed at the outer edge of the aperture, tise upper half divaricated. Vesicles vasiform.

Corallina muscosa, alterna vice denticulata, ramulis in creberrima capillamenta sparsis, Raii Synop. Stirp., vol. 1, p. 36, no. 16. Squirrel's 'Tail, Ellis' Coral., 6, no. 4, lab. 2, fig. c. C. Sertularia Argentea, Ellis and Solander's Zooph., no. 4. p. 38. Turton's Lin., vol. 4, p. 667. Stewart's Elem., vol. 2, p. 442. Templeton in Mag. Nat. Hist., vol. 9, p. 468. Johnston's Brit. Zooph., p. 134, pl. xii. and pl. xi., fig. 3, 3. Dynamena Argentea, Fleming's Brit. An., p. 544. Sertularia Argentea, Lamouroux's Cor. Flex., p. 192.

Hab. On stones and shells from deep water off Polperro, common; St. Ives bay.

Since writing the paper on the Zoophytes of Cornwall for the Polytechnic Society, I have found this species to be more common in deep water than I had previously supposed. In the adult state it is the most beautiful of all our corallines. The stem is smooth, without cells, divided at irregular intervals by imperfect septa, and grows to the height of eighteen inches. The pinnæ, which bear the cells, arise in pairs from each internode in such a manner that five or six encircle the stem; and as each pinna is again branched in an irregular, though somewhat dichotomous manner, the whole forms so bushy an appearence, as entirely to hide the stem from view, from which circumstance it derives its name. The polypidom sometimes consists of a single stem only, but at others it has one or more branches of the same size and character as the primary trunk, which greatly adds to the beauty of the species. On our shores, however, the larger specimens are generally much injured from the violence of the waves; having their cells and pinnæ broken or washed off. The cells are biserial, alternate, bulging at the base with diverging and contracted necks; their apertures are but slightly everted, being rather directed upwards and laterally than outwards. In sonse specimens the outer edge of the mouth is produced into a sharp point, which in many others is wanting, the apertures being altogether plain. The vesicles arise along the upper edges of the pinnx, and are vasiform, inclining to the ovoid, smooth, and transparent when living, semi-opaque and transversely wrinkled, when preserved.

Young specimens are very common in deep water, at from one to seven or eight leagues from land, but in form they bear no resermblance to the old. They are simply pinnated in an 


\section{6}

alternate manner; the stem is slightly zig-zag with a few distantly arranged cells on it. The upper part of the stem, in this variety, frequently bends from the straight line at an obtuse angle. In young and newly formed parts the colour is of a pure silvery white, which changes with age to a straw yellow and finally to a brown colour.

SEA CYPRESS. S. Cupressina. Polypidom cauliferous; cells nearly opposite, tubulous, adnate; aperture large and not everted, with one large and two small lateral teeth. Vesicles vasiform,

Sea Cypress, Ellis' Coral., p. 7, no. 5, tah. 3, fig. a A. Sertularia Cupressina, Ellis and Solander's Zooph., p. 38, no. 5. Turton's Lin., vol. 4, p. 66\%. Stewart's Elem., vol. 2, p. 442. Templeton in Mag. Nat. Hist., vol.9, p. 468. Johnston's Brit. Zooph., p. 135, pl. xiii. Dynamena Cupressina, Fleming's Brit. An., p. 543.

Ilab. St. Ires bay.

The only Cornish locality from which this species has been obtained is St. Ives bay; from which I have procured three specimens. It is stouter and more spiry than the last. The stem is stout and gradually tapers from the base to the apex; and is slightly zig-zag, which is made more apparent by the pinna falling off and leaving a slight protuberance. The pinnæ are alternate and branched, the branches hanging nearly parallel to each other. The cells are biserial, closely arranged and semi-alternate or opposite; they are smooth, and closely adherent; the base slightly bulging; the apertures look upward, are patulous and armed with a long tooth on the outer, with two smaller ones on the lateral edge, on each side of the pinnæ. The vesicles are vasiform with short peduncles; their apertures, small and tubular, and at the base of the neck are two large spines, which however are occasionally absent. The vesicles are sometimes so abundantly produced on the upper edges of the pinnæ, as to bend them into arches, which gives the polypidom a peculiarly graceful appearance.

This species bears so close a resemblance to the last, that Pallas considered them to be no more than varieties of the same, and in this opinion he was followed by Linnæus. But Ellis in his work edited by Solander, opposes such an opinion. He says, "these last two Corallines, though supposed by Linnæus to be the same, when they come to be compared, have quite a different habit and manner of growing. The latter or Sea Cypress is always found in very deep water, and the side branches often as long again as the Squirrel's Tail." In addition to this I have observed that 
the cells of the S. argentea never possess the lateral teeth observed in the S. cupressina. The prominent tooth on the external edge of the apertures of the latter is sometimes found in the former; and the lateral teeth which are always absent in the $\mathbf{S}$. argentea are sometimes deficient in the S. cupressina; and in such a case it would be almost impossible to decide to which species, such a specimen belonged. Ellis says the S. cupressina grows in deep water, while the other is confined to siallower water near the shores. My observations are just the reverse of this; for all the specimens of the S. argentea which I have found on the Cornish coast have been at from eight to ten leagues from land, in about fifty fathoms water. At what depth the S. cupressina grows about St. Ives I do not know, bat the water in that neighbourhood, though deep, is, I believe, rather shallower, than of that portion of the Eaglish channel from which my specimens of the S. argentea have come.

THUIARIA. Fleming.

Generic Character: Polypidom plant-like, rooted by tubular fibres, erect, dichotomously branched or pinnated; the cells sessile, biserial, adnate to the rachis, or imbedded in the substance of the stem and branches; vesicles scattered; polypes hydraform.

The most characteristic difference between this and the preceding genus, and by which it may be distinguished at once, is that the cells are imbedded or close to the stem, and the aperture not everted.

BOTTLE-BRUSH CORALLINE. Thuiaria Thuia. "Cells ovato-elliptical, rather acute; vesicles pear shaped."Sibbald.

Bottle-brush Coralline, Ellis' Coral., p. 10, no, 9, pl. 5, fig. b B. Sertularia Thuja, Ellis and Solander's Zooph., p. 41. Turton's Lin., vol. 4, p. 678. Stewart's Elem., vol. 2, p. 442. Lamouroux's Cor. Flex., p. 193. Thuiaria Thuia, Fleming's Brit. An., p. 545. Johnston's Brit., Zooph., p. 137, pls. xiv. and $x v_{\text {., figs. } 1 \text {, and } 2 .}$

Hab. From deep water. Polperro.

"Stem percurrent, erect, filiform, rigid, zig-zag, knotted, naked underneath, bearing on the upper pari, a cylindrical tuft of dichotomous short equal branches, coming off alternately, and so disposed that four complete a whirl." "Cells close pressed, arranged in two rows, sub-alternate, smooth, tapered from the base to a contracted orifice." Johnston. $\Lambda$ single specimen is all that has yet been obtained.

The young of this species very much resembles the next, (Th. Articulata), but may always be distinguished from it, 
by its haring great intervals between the pinnæ, aud the cells not having their apertures everted as in the following species; and beside this the aperture here is always pointed.

\section{SEA SPLEENWORT, OR POLYPODY. Th. Arti-} culata. Polypidom plumous; stem of equal thickness thronghout; pinnæ stont, closely arranged, alternate; cells biserial on the pinnæ and stem ; imbedded, closely arranged, alternate; vesieles elliptical.

Sea Spleenwort or Polybody, Ellis' Coral., p. 11, no. 10, pl. 6, fig. a A. Sertularia Lonchitis, Ellis and Solander's Zooph., p. 42. Sertularia Lichenastrum, Turton's Lin., vol. 4, p. 683. Stewart's Flem., vol. 2, p. 447. Thuiaria Articulata, Fleming's Brit., An., p. 545. Johnstun's Brit., Zooph., p. 138, pl. 15, fig. 3 and 4.

Hab. On the back of the corwich crab, (Maia Verrucosa) Polperro, Goran-haven on a stone from deep water, Mr. Peach. It is not at all rare to meet with fragments, with all or most of the pinnæ gone, but it is very rare to meet with a good specimen.

This species varies in height from two to four inches, but one specimen which Mr. Peach procured from Torbay, Deronshire, measured five inches and a quarter. When liring it is of a beautiful pellucid amber colour, which becomes duller in dying. The stem is stout, of nearly equal thickness throughout, and divided very irregularly by imperfect septa. The pinnæ, which are closely arranged, arise from the stem in an alternate manner, and are confined to its upper part; those on the lower portions are thrown off in regular succession, as the polypidom advances in growth. The cells are biserial, on the pinnæ and trunk, adnate, closely arranged, alternate; their apertures are even, everted and not prominent The vesicles arise from each side of the pinnæ, but most numerously from the upper; they are oriform, sub-pedunculated, with contracted terminal apertures.

Fragments of this species are frequently found on the backs of corwich crals in the spring and summer, when they first move from their hybernating retreat. On shells and stones, eight or ten leagues from land in about fifty fathoms water, after some weeks of continued fine weather, they have been found in a very perfect state.

\section{ANTENNULARIA. Lamarck.}

Generic Character: Plant like, horny, simple or branched irregularly, the shoots fistular, jointed, clothed with hairlike verticillate branchlets; cells small, sessile, campanulate, unilateral; vesicles scattered and unilateral. Polypes hydraform. 
LOBSTER'S-HORN CORALLINE, OR SEA BEARD. $A$. Antennina. Stem covered with hair-like branchlets, arranged in a circular manner round the stem : cells wineglass shaped, with two hollow denticles between each. Pl. vii.

Lobster's-horn coralline, or sea-beard, Ellis' Cor., p. 15, no. 14, pl. 9, fig. a b, A. B. C. Sert. antennina, Tur-ton's Lin., vol. 4, p. 679. Stewart's Elem., vol. 2, p. 443. Ant. antennina, Fleming's Brit. An., p. 516. Johnston's Brit. Zooph., p. 139, pl. xvi. Ellis and Solander's Zooph., p. 45.

Var. 1. Not brancbed. Corallina astaci corniculorum æmula.-Muscus marinus seu Coralloides non ramosus erectus, Raii, Synop. Stirp., vol. 1, p. 34, no. 10. Ant. indivisa, Templeton in Mag. Nat. Hist., vol. 9, p. 468. Johnston's Brit. Zooph., p. 139, pl. 16, tig. 1.

Var. 2. Branched. Corallina ramosa cirris obsita, Raii, Synop. Siipp., vol. 1, p. 35, no. 11. Ant. ramosa, T'empleton in Mag. Nat. Hist. vol. 9, p. 468. Johnston's Brit. Zooph., pl, xvi., fig. 2.

Hab. On Pinna ingens, oysters, shells, stones, and sand, from deep water; very common, especially in oyster beds.

There are two variations of this species which at first would seem to constitute specifịc differences, but after many examinations, I am inclined to think they are only varieties, and Dr. Johnston is of the same opinion.

The first variely geverally grows in clusters on sandy soils or on stones lying in sand, rooted together by small brown tubular fibres, which are malled together by sand and fragments of shells. The stem grows to the beight of about eleven inches, surrounded by its hair-like branches.

The second variety grows most commonly on oysters in single specimens, and not in tufts as the tirst. The branches generally arise from the lower part of the stem and nearly at right angles; sometimes at about $45^{\circ}$, and from all parts of the stem. The branches are similar to the trunk, and straight; though I have another variety about nine inches in beight, which is branched, and the branches again branched like a tree, variously iwisted and bent. The stem and branches are of a yellow pellucid born colour, when living, but are duller in dead specimens; they are of equal thickness throughout and divided at sbort intervals by imperfect septa. The branchlets surround the branches and stem, in a vericillate manner, and are so slender that they resemble hair. The branchlets have a single row of cup-like cells, distantly arranged on their upper edges. The cells rest 
one on each internode, and between them are two minute hollow denticles, which are visible only under a microscope. One of these minute denticles appears to be placed on an inter-articular portion placed between the extremities of the internodes. The cells are small, cup-shaped, with patulous unarmed apertures which are directed upwards. The vesicles are situated in the axillæ of the branchlets, or where they arise from the stem, they are pear-shaped, rather small, smooth with contrasted subterminal apertures. In specimens washed on shore, the branchle's are commonly broken off or much ijjured, those taken in trawl nets have them about the sixth of an inch in length, while those from deep water which have been brought up by the hook, very frequently have them three quarters of an inch in length.

\section{PLUMULARIA. Lamark.}

Generic Character: Plant-like, rooted, simple or branched; the shoots or offsets plumous; cells uniserial, small, sessile, unilateral, usually seated in the axilla of a horny spine; vesicles scattered, unilateral. Polypes hydraform.

The general appearance of this genus is the same as that of Sertularia ; but it is distinguished from it by having only one row of cells on the pinnæ.

\section{* Stem a single tube.}

SICKLE CORALLINE. P. Falcata. Stem waved, branched, alternately pinnated; cells crowded in a single row, with plain apertures, tubular, slightly bulging at the base.

Corallina muscosa pennata, ramulis et capillamentis falcatis, Raii, Synop. Stirp., vol.1, p. 36, no. 16. Sickle Coralline, Ellis' Cor., p. 12, pl. 7, fig. a A, pl. 38, fig. 6. Sert. falcata, Ellis and Solander's Zooph., p. 42. Turton's Lin., vol. 4, p. 679. Blumenbach's Man., p. 273. Stewart's Elem., vol. 2, p. 443. Plum. falcata, Fleming's Brit. An., p. 546. Templeton in Mag. Nat. Hist, vol. 9, p. 466. Johnslon's Brit. Zooph., p. 14l, pl. xviii., figs. 1, 2.

Hab. On shells from deep water, from the Eddystone to the Lizard; common.

This species rises to the height of from four to eight inches. The stem is waved, slender, of equal thickness throughout, brown, smooth and divided at irregular intervals hy imperfect septa. The branches arise somewhat irregularly, but most commonly from the convex side of the waved line of the stem or trunk; and in companies of three or four. In this manner it may be said that the branches arise in alternate threes. They are pinnated; the pinnæ are alternate and irregularly dirided by imperfect septa. The cells are unila- 
teral, closely arranged, bulging at the base, contracted at the neck, with unarmed apertures pointed at the outer margin, and are situated on the branches and pinne only. The cells on each internode of the pinnæe are crowded together and in contact; but where the internodes join, there is a vacancy, so that they look as if congregated into parallel companies, similar to what occurs in the genus Serialaria. A variety frequently occurs in the distribution of the cells which present the appearance of being arranged in a double row. This is produced by the cells, instead of being arranged in a close straight row, being made to lie alternately on eitler side of a median line, much in the same way as if the teeth of a saw were bent alternately in opposite directions. The vesicles are pear-shaped, furrowed, with contracted tubular apertures, pedunculated, and irregularly distributed.

Ellis has given a very good figure of this species, in the centre of the curious frontispiece to his Essay on Corallines. The figure at pl. 7 is not so good either as that, or the one at pl. 38, fig. 6 , which he sufficiently explains, by saying it was taken from a dried specimen. Dr. Grant, as quoted by Johnston, represents the terminations of the stems in this species, as being open during growth; a remark which my opportunities do not enable me to confirm.

PODDED CORALLINE. P. Cristata. Stem simple, plumous; pinnæe alternate; cells unilateral, in a close row on the upper side of the pinnæ; apertures large; margins deeply dentated, with a prominent spine, inferior to the rim; vesicles barrel-shaped, with serrated ribs. Pl, viii.

The Podded Coralline, Ellis' Coral., p. 13, no. 12, pl. 7, fig. b B. Sertularia pluma, Ellis and Solander's Zooplı., p. 43. Turton's Lin., vol. 4, p. 679, Stewart's Elem., vol.2, p. 448. Aglaophenia pluma, Lamouroux's Coral., Flex., p. 170. Plumularia pluma, Fleming's Brit. An., p. 546. Plumulata cristata, Templeton in Mag. Nat. Histo, vol. 9, p. 467. Johnston's Brit. Zooph., p. 143, pl. 19, figs. and 3, pl. 20, fig. 1 .

Hab. On Ascidia, Fuci, Pinna ingens, oysters, stones, from one to fifty fathoms of water, very common. Polperro, Looe, Seaton, Goran, Port Loe, \&c.

This common and delicate species is attached to the substances on which it grows by means of brown, creeping, tubular fibres, which irail irregularly in all directions, and send off plumous shoots from one to three and half inches high, irregularly throughout its course. The stem is polished, jointed, of a dark brown, and frequently almost of a black 
colour. The pinnæe are of a lighter colour, alternate, closely arranged in pairs on each internode, and rary from one eighth to two thirds of an inch in length. The cells are uniserial, crowded, and cup-shaped; the apertures, patulous, deeply notched with about eight indentations, and at a short distance beneath the rim is a stout rounded spine. Each cell rests on a separate internode of the pinna. The vesicles, though liable to much variation, have all a very peculiar and characteristic appearance, resembling minute barrels, embraced with from five to nine serraled ribs. They are quite transparent when living, allowing their irregularly shaped ova to be seen throngh the sides; but when dry, they become opaque and of a pearly hue. They are generally attached to the pinna throughout their length by a dorsal band. This band is sometinses free and arched, and the vesicles attached only at the extremities. The circular ribs bave sometimes only one prominent serrated rim and at otbers two.

The description of the cells given above, is taken from such specimens as most nearly approach to the descriptions and figures of authors, more especially of Ellis and Johnston. But there are variations from this standard, too remarkable to be passed unnoticed. In no specimen bave I seen the cells so crowded as in Johnston's figure; Ellis' at pl, 7, more closely approaches to the mode of distribution observed in Cornish specimens, but he bas omitted the sub-marginal spine; the artist having drawn from an oblique back view, instead of a lateral one, as be himself remarks. In one variety the cells are deeply tubular; the mouth is deeply indented with five, six, or seven teeth; the spine beneath the aperture, is stout, and in those cells on the lower pinnæ, frequently twice as long as the diameter of the cell. Above each aperture and attached to the upper portion of each internode, is a short tubular process which lies across the mouth of the cell; it has a rounded termination, with a subierminal opening on the upper surface, very closely resembling what is observed in the Cellaria Bursaria or shepherd's purse Coralline: a form more clearly observable in the dried than in the living state. There is also a minute variety growing on the smaller fuci, stones and shells about low water mark, which rarely exceeds half an inch in height; in which, the pinnæ are very slender and long, equalling in length, the height of the stem. It resembles the common specimens in every respect, except that every part is more minute. Though these are here called varieties, yet one of them may probably prove a distinct species.

The figure of this species, illustrating this essay, is of the natural size of a very fine specimen from deep water. The draughtsman has onitted the cells on a portion of the plume on the right side. 


\section{3}

P. PENNATULA. "Plumose; the pinnæ opposite; cells in a close row, cup-like, with an unequally crenated margin, supported on the under side, by a lengthened incurved spinous process." Montagu.

Sertularia pennatula, Ellis and Solander's Zooph., p. 56, tab. 7, figs. 1 and 2. Aglaophenia pennatula, Lamouroux's Cor. Flex., p. 168. Sert. pennatula, Turton's Lin., vol 4, p. 681. Plum. pennatula, Fleming's Br. An., p. 546. Johnston's Brit. Zooph., p. 145, pl. 8, figs. 1 and 2.

Hab. On Pinna ingens, from deep water, off Deadman point, very rare.

This is so rare a species, that I have met with but one specimen. In its general appearance it approaches very closely to the Podded Coralline; from which however it is very readily distinguished. The stem is divided into joints, each bearing two pinnæ; the pinnæe are closely arranged, waved and opposite. The cells are unilateral, on the inferior edge of the pinnæ, one on each internode; they are small, cup-shaped, with irregular patulous apertures, and with a minate denticle on each side; from the base of each proceeds a long lubular spine, which varies in length from two to two and half times the diameter of the cell and rises above it. The specimen procured in the Cornish seas, was not so closely pinated as Ellis' beautiful figure, but more so than Jobnston's.

That variety of the Podded Coralline, which has the lengthered sub-marginal spine, bears a great resemblance to this species. But it is distinguished from it, by the cells being on the upper margin of the pisnæ, deeply tubular, by the regularity and decided manner in which the margin is dentated, and by the spine, though long, projecting from the side of the cell, leaving a space between it and the margin of the mouth, which is not the case in this species.

SEA BRISTLES. P. Selacea. Plumose; the pinnæe alternate, one on each internode of the stem, rising near the joint on a slight protuberance; cells distant, cup-shaped, with an eren margin, resting on an enlargement of the branch, with two minute teeth between each; vesicles elliptical, smooth.

Sea Bristles, Ellis' Coral., p. 19, pl. xi., no. 16, a A., tab. 38, figs. 4, D.T. Aglaoph. setacea, Lamoroux's Cor. Flex., p. 172. Sert. pinnata, Stewart's Elem., vol. 2, p. 446. Sert. selacea, Turton's Lin., vol. 4, p. 683. Plum. setacea, Flem.ing's Brit. An., p. 547. Templeton in Mag. Nat. Hist., vol. 9, p. 467. Johnston's Brit. Zooph., p. 146, pl. 18, figs. 3 and 5. 
Hab. On shells and stones from deep water, common, from Falmouth to Plymouth.

This species varies from one to six inches in height, and is delicate and drooping when large. The trunk is divided by septa, between each of which are placed one or two rings of an inter-articular substance, which is well figured by Johnston; each internode gives off one pinna at its upper end, which rests on a protuberance of the stem, and gives it a waved appearance. The joints of the pinnæ are also separated by the inter-articular rings. The cells are distant small, cup-shaped, situated on a protuberance of the internode, and their apertures are plain and even. Between the cells are two minute hollow teeth, visible only under a high magnifier.

Dr. Johnston, in his references, has not considered that Ellis' figure, pl. xi., no. 16, a A, refers to this species; or at least he has not referred to it, as he has to the figure at plate 38. But no. 16, at plate xi., is a very good likeness of those I have found growing on shells on this coast, and figure A, appears to be a magnified representation of the same; though Dr. Jolnnston thinks both refer to Plumularia pinnata: in $P$. pinnata, the pinnæ arise from each internode, and the vesicles are strongly toothed, while in P. setacea, as in Ellis' figure, there is only one pinna arising from each internode. Dr. Fleming has united them under one name. There appear to be three varieties of this species which has probably given rise to this confusion.

The first variety, the longest with the shortest pinnæ, is figured by Johnston at pl. xviii., figs. 4, 5, and generally grows on stones:

The second, on shells, feather-like in appearance, and like the figure of Ellis' at pl. xl., no. 16, a, on which 1 have found abundance of vesicles like those figured surrounding the stem, and not placed in the axilla of the pinnæ:

The third, always parasitical, and most commonly on the Plumularia frutescens, is figured by Johnston, pl. sviii., fig. 3, and Ellis' Corallines, pl. 38, fig. 4.

BRANCHED SEA BRISTLES. P. Pinnata. "Stem plumous ; the pinnæ alternate; cells rather distant, one on each internode, campanulate, leaning, the mouth entire; vesicles obpyriform, strongly toothed above. Dillenius."

Fucoides setis minimis indivisis constans, Raii, Synop., vol. 1, p. 39. Sert. pinnata, Turton's Lin., vol. 4, p. 683. Stewart's Elem., vol. 2, p. 446 . Plum. pinnata, Johnston in Mag. Nat. Hist., vol. 6, p. 498. Aglaophenia pinnata, Lamouroux's Cor. Flex., p. 172. Plum. pinnata, Jobnston's Brit. Zooph., p. 145, pl. $x$ vii., fgs. 4 and 5 . 
Hab. On shells, and on the back of the Corwich crab, common. Polperro.

This delicate species is commonly found about from one to two and half inches higl, "but sometimes attains the height of four inches." It is of a delicate straw colour throughout, but the pinna are rather lighter than the stalk. The stalk is divided at regular intervals into joints, is smooth ant destitute of cells. The pinne are alternate and arise in threes from each internode, thongh I have seen specimens in which they arose in pairs. Each pinna arises from an enlargement of the stem, and like the stem, is divided into joints. The joints or internodes are ahout five or six times as long as their diameter and irregularly waved. The cells are transparent, unilateral, small, distant, cup-shaped and lying on enlargements of the internodes their apertures are patulous and even. Between the cells, one on each internode, is a minute curved denticle, with its convexity turned upwards. The vesicles are sometimes very numerously produced, and are axillary; when young, ovoid; but when the gemmules are fit for expulsion, the upper part bursts into deep indentations, giving the appearance, as Ellis says, of being "divided like a coronet."

This species very closely resemble $\mathbf{P}$. setacea in general appearance and shape of the cells; but is distinguished from it by having three pinna on each internode of the stem instead of one; and by having only one denticle between the cells instead of two.

PLUMULARIA CATHERINA. "Stem plumous, the pinnæ opposite, bent inwards; cells distant, campanulate, with an even margin; vesicles scaltered, pear-shaped, smooth." Johnston.

Plumularia Catherina, Johnston in Mag. Nat. Hist, vol. 6, p. 498, figs. 61, 62. British Zooph., p. 147, vignette no. 8, p. 79, p. 148, fig. 16.

Hab. On Pinna ingens, in deep water five leagues off the Deadman; common.

This is the most slender of all the species I have seen. Its pinne are opposite, and "insteal of being arched bend inwards, so as to render the general form of the coralline concave on a front view, an appearance produced by the pinna originating not from the sides, but from the anterior face of the stem." Johnston. The cells are minute, cupshaped, situated on an enlargement of the internodes of the pinnæ; and between the cells are numerous minute hollow teeth, visible only under a very high magnifier. The vesicles are pear-shaped, with a contracted mouth frequently 
covered by a lid or operculum. I have found it growing profusely on the bottom of a vessel which had been laying in Fowey harbour for some months. This species was first described by Dr. Johnston and figured by his lady, and in honour of her is called "Catherina."

\section{** Stems composed of many parallel tubes.}

PHEASANT'S-'TAIL CORALLINE. P. Myriophyllum. "Clustered, the stems undivided, bellied at distant intervals, pinnate; pinne leaning to one side; cells shortly tubular, seated in the axilla of a curved spinous process, the aperture wide and nearly even." Pl. ix.

Pheasant's-tail Coralline, Ellis' Coral., p. 14, pl. 8, no. 10, fig, a A. Aglaoph. myriophyllum, Lamoroux's Cor. Flex., p. 168. Sert. myriophyllum, Turton's Lin., vol. 4, p. 678. Ellis and Solander's Zooph., p. 44. Stewart's Elem., vol. 2, p. 443. Plum. myriophyllum, Fleming's Brit. An., p. 547. Templeton in Mag. Nat. Hist., vol. 9, p. 466. Johnston's Brit. Zooph., p. 148, pl. 19, figs. 4, 5 .

Hab. "On the back of the spider crab, and on a slab of limestone." Goran, Mr. Peach.

This beautiful coralline is of rare occurrence in our seas. I have never procured a specimen myself, but Mr. Peach has kindly favoured me with three from deep water off Goran, one of which is remarkably fine, measuring six and half inches in height; from these I have taken the following description. The polypidom is stout, erect, and of a yellowish horn colour. The trunk is stout, composed of many sub-parallel tubes agglutinated logether; marked on ihe back, at intervals of from a quarter to one inch, with proiuberances, as if it was composed of internodes, which overlapped each other at their extremities; the overlapping parts are united by transverse fibres, which do not appear to be parts of the same tubes which compose the stem. In recent specimens the tubes are not so apparent as in the dried state. When dried the stem is furrowed longitudinally, and in the furrows, thickly marked with minute round orifices; similar in appearance and perbaps in function, to the stomata of flowering plants. The pinnæ are confined to the upper portions of the stem, the lower, for one third or two thirds of its extent being bare; they are divided at short intervals into joints, are opposite, but from their frequently leaning all to one side, they appear to be unilateral. The cells are deeply tubular closely arranged one on each internode and attached to the pinnæ throughout their whole length; they are unilateral and placed on the inferior margins of the pinnæe in the asillæ of a curved spine. The apertures of the cells are patulous 
slightly pointed on the outer, and waved on the lateral margins.

Ellis states that his specimen had no ovarian resicle and that he had never seen any; Johnston, Lamouroux and all other authorities to whom I liave access do not mention them, and the specimens I have are without any, so that at present they appear to be unknown.*

SHRUBBY CORALLINE. Plumularia Frutescens. Stem dark brown, composed of sub-parallel tubes irregularly branched, branches pinnate, pinna alternate, bifid; cells distant, ovato-tubular with plain and slightly everted rims; vesicles ovoid, smooth, with small terminal apertures.

Sertularia frutescens, Ellis and Solander's Zooph., p. 55, pl. 6, fig. a A, pl. 9, figs. 1, 2, covered by an Alcyonium. Turton's Lin,, vol. 4, p. 680. Stewart's Elem., vol. 2, p. 445. Plum. frutessens, Fleming's-Brit. An., p. 54\%. Johnston's Brit. Zooph., p. 149, pl. 20, figs. 2, 3. Aglaophenia frutescens, Lamouroux's Cor. Hlex., p. 173.

Hab. On stones from deep water, from the Eddystone to the Deadman. Common, but not abundant.

This species is of a dark brown colour and varies from one to five inches in height. The stem is composed of aggregated sub-parallel tubes of a dusky brown colour, and not polished. The pinnæe are closely arranged, formed of single tubes and bifurcated, with one cell on each internode. The cells much resemble old fashioned cuffee cups, with patulous apertures having slightly everted rims. They lie close to the pinnæe, and are lodged in a slight cavity of the internode, with a transparent triangular denticle between each. Sometimes they are much branched and bushy, but most commonly are only a simple frond. The vesicles are numerously produced in March and April, on the upper edges of the pinna. They are small, ovoid, with prolonged terminal apertures.

\section{LAOMEDEA. Lamouroux.}

Generic Character: Polypidom rooted by a creeping fibre, plant-like, erect; jointed at regular intervals, the joints ringed, incrassated, giving origin, alternately on opposite sides, to the shortly pedicled cells; cells campanulate; vesicles axillary. Polypes hydraform.

SEA THREAD COPALLINE. L. Dichotoma. Stem filiform, brasched dichotomously; cells alternate campanulate, the rim even.

* The vesicles of this species have since been seen by the Rev. D. Lunsborough of Ayrshire, he says "they are as remarkable as those of P. Cristata," but does not describe then. 'Zoologist, vol, 1, 1. SS. 
Sea thread coralline, Ellis' Coral., p. 21, pl. xii., no. 18, a A. Sert. dichotoma, Ellis and Solander's Zooph., p. 48. Turton's Lin., vol. 4, p. 682. Stewart's Elem., vol. 2, p. 446. Campanularia dichotoma, Fleming's Brit. An., p. 548. Grant's Comparative Anatomy, 10, fig. 5. Cyclop. of Anatomy and Physiology, p. 108, fig. 30. Templetun in Mag. Nat. Hist., vol. 9, p. 469. Laomedea dichotoma, Lamouroux's Cor. Flex., p. 20\%. Johnston's Brit. Zooph., p. 150, pl. 22, figs. 1 and 2.

Hab. On stones from deep water, common; in pools about low water mark; in Whitsand bay, Looe, Polperro, near Fowey, and Goran; common. On sponges, rare.

It grows to the height of from six to ten inches, but is more commonly about one. The appearance of this species is confervoid. It is of a light transparent horn colonr, rooted by minute tubular fibres; erect and dichotomously branched. The cells are campanulate, biserial, on annulated footstalks a little longer than the depth of the cell; the apertures are even and unarmed. The whole polypidom is oivided into long internodes, and the branches at their origin are annulated, and those parts of the stem and branches which give support to the cells are enlarged into kneed protuberances. The vesicles are ovoid, or urn-shaped and axillary. The ova are numerous and composed of two parts, a central dark nucleus and a light surrounding zone. Beside this there are some curious phenomena connected with the gemmules, which are not mentioned here, because the nature and character of them are exceedingly obscure: Sir J. G. Dalyell has also noticed them, but not explained them; they are therefore retained for further consideration. Wllis says it " seems most curiously contrived, from its structure, to resist the violence of the waves, all its joints being furnished with springs."

KNOTTED SEA THREAD. I. Geniculata. Short; stem zig-zag, rarely branched; cells bell-shaped, alternate, with an even rim, on ringed foot-stalks, standing on a thickened joint of the stem. Pl. x,

Corallina confervoides gelatinosa alba, geniculis crassiusculis pellucidis, Raii, synop. Stirp. vol. 1, p. 34 no.7. Knotted thread Corallice, Ellis' Coral., p. 22, pl. 12, no. 19, fig. b B. Sert. geniculata, Ellis and Solander's Zooph., p. 49. Turton's Lin., vol. 4, p. 682 . Stewart's Elem., vol. 2, p. 446. Campanularia geniculata, Fleming's Brit. An., p. 548. Laomedea geniculata, Lamouroux's Cor. Fles., 208. Templeton in Mag. Nat. Hist, vol. 9, p. 466 . Johnston's Brit. Zooph., p. 151, pl. xxi., figs. 1 and 2. 
Hab. On floating fuci; on fuci near low water mark; on the under surface of stones in brackish water; gregarious; abundant through the year.

This small species varies from half an inch, to one inch in height, and is liable to variations in colour from a white to a deep red. It is gregarious on almost all the larger sea weed, about the tide marks, especially the Fucus serratus. It is rooted by small creeping tubular fibres, which trail along the surface of the substance on which it grows and gives off new polypidoms at irregular intervals in its course. It is erect and sparingly branched, the stem is zig-zag and divided into joints. At the upper extremity of each internode is an enlargement, on which rests a ringed peduncle which bears the cell. The peduncle is composed of from four to six annulations. The cells are campanulate with even unarmed apertures. The vesicles are axillary, vasiform, and are to be found throughout the summer. The horny sheath of this and the following species, is so transparent, that the central granular pulp, and the polypes with their tentacula may be distinctly seen through its sides. The number of tentacula varies from fourteen to twenty eight.

Some of the finest specimens $\mathbb{I}$ have seen were growing on the dorsal and caudal fins of a Picked Dogfish.

I. GELATINOSA. "Suhordinate branches dichotomously branched; cells on twisted footstalks, campanulate, with even margins." Ellis. P1. x.

Fucoides setaceum tenuissime alatum, Raii, Synop. Stirp.s vol. 1, p. 38, no. 6, pl. 2, fig. 2. Corallina filiformis ramosa pedunculis calyculorum contortis, Ellis' Coral., pl. 38, fig. 3, p. 23, pl. 12, fig. c C. Sert. gelatinosa, Stewart's Elem., vol. 2, p. 444. Campanularia gelantinosa, Fleming's Brit. An., p. 549. L. gelatinosa, Johnston's Brit. Zooph., p. 152, pl. 21, figs, 3 and 4 , pl. 23, fig. 1 .

Hab. On stones near low water mark and in pools. Polperro; common.

"This species" Johnston says "in its most perfect state rises to the height of eight or ten inches." But it is more commonly found about one, and so closely resembling the last that it will be best described in connection with it. In the habit and mode of growth there is but little distinction. In this the stem is more waved, not so zig-zag, and more slender; the cells are larger and deeper; the footstalks longer and not situated on any swelling of the stem. The vesicles are vasiform, axillary, and on ringed footstalks. T lie manner in which the gemmules are produced difiers. In the last species the whole of the granular pulp is formed into the gemmules, then they escape, leaving the case empty; in 
this there is a central placentral column to which the gemmules are attached by an umbilical cord.* The polypes are alike in both, and are liable to the same variations and irregularities in the number of their tentacula.

This species is sometimes abundant under large stones between tide marks, in sheltered situations, on sea weed and other marine productions, and is more abundant than I had previously suspected.

This is said to grow to the height of eight or ten inches, but is more commonly found about one. It is very slightly branched, much resembling the "knotled sea thread," from which it is not at all times easy to distinguish it; but the twisted or ringed foot-stalks to the cells are longer, and not placed on enlarged parts of the stem, as in that species. "The cells are deeply cupped, transparent, with a wide even margin." The vesicles are urn-shaped, axillary and smooth.

\section{CAMPANULARIA.}

Generic Character: Polypidom rooted, creeping, or when compound erect, the main tube filiform, continuous, giving off its pedunculated cells irregularly or in whorls; pedicles frequently ringed, usually long; cells campanulate; vesicles scattered, sessile. Polypes hydraform.

* Siem a single tube.

SMALI CLIMBING CORALLINE. C. Volubilis. Stem creeping, tortuous, filiform ; cells bell-shaped, with serrated rims on long slender ringed foot-stalks; vesicles irregularly ovoid, corrugated.

Small climbing Coralline, with bell-shaped cups, Ellis' Coral., p. 24, no. 21, pl. 14, fig. a A. Sert. volubilis, Ellis and Solander's Zooph., p. 51, pl. 4, fig. e, f, E. F. Turton's Lin., vol. 4 p. 680. Stewart's Elem., vol. 2, p. 444. Clytia volubilis, Lamourous's Cor. Flex, p. 202, no. 340. Canpanularia volubilis, Fleming's Brit. An., p. 548. Templeton in Mag. Nat. Ilist., vol. 9, p. 466. Johnstun's Brit. Zooph., p. 154, fig. $1 \%$.

Hab. On the great tooth coralline, on the antennæ of the Corwich crab, on the remains of corallines, and Pinna ingens. Common. Polperro.

This species is very minute and so escapes common observation, but it is not at all rare on the remains of old corallines, and on the antennæe of crabs, where it enjoys all the advantages of locomotion in taking its prey. The cells are bell-shaped, sometimes shallow and at others deep, with serrated mar-

* Vide, Introduction to the Hydroida, p. 4. 
gins, on long slender foot-stalks ringed in two places, at their origins and near the cells; but the animal possesses the power of corragating the whole, and rnaking it lonk annular, as in the figure of Ellis and Solander tab. 4, E. F. These ringed foot-stalks arise in an alternate manner from a hollow creeping horny tube; variously twisting over the substance on which it grows. The vesicles are ovoid, but very much corrugated transversely, and arise from the creeping trunk on a short foot-stalk. Polypes with twenty tentacula of a light colour.

CREEPING BELL CORALLINE. C. Syringa. "Stem creeping, capillary; cells on short twisted foot-stalks," deeply tubular, with plain even apertures.

Creeping bell Coralline, Ellis' Coral., p. 25, pl. 14, fig. b B. Sert. syringa, Turton's Lin., vol. 4, p. 680. Stewart's Elem., vol. 2, p. 444. Sert. repeas, Ellis and Solander's Zooph., p. 52. Clytia syringa, Lamouroux's Cor. Fles., p. 203. Campanularia syringa, Fleming's Brit. An., p. 548. Johnston's Brit. Zooph., p. 155, fig. 18.

Hab. On the antennæ of the spider crabs, and on the remains of old corallines in company with the small climbing coralline. Polperro, Goran, Fowey, Whitsand and St. Austle bays.

In consequence of the minute size of this and the last species, it is necessary to examine them with a microscope to discover their specific differences. They most commonly grow together, but this is distinguished by the shortness of the ringed foot-stalk to the cells; the depth, tubuliform character, and stoutness of the cells. The apertures are not patulous and are plain and even, while those of the las,t are serrated.

CAMPANULARIA INTERTEXTA. R.Q.C. Texture spongy, composed of single tubular fibres very much interwoven with each other, not ringed; cells campanulate; apertures even. Pl.xi.

This which is I believe quite new, differs so remarkably from any of the kindred species, that it cannot easily be mistaken. It so closely resembled a very loose textured sponge, that several specimens were laid aside for a time, till that class came under consideration. I have found many specimens encrusting the Sertularia polyzonias, Campanularia dumosa and other corallines from deep water about seven leagues from the Deadman, in a line S.E. to S.S.W. It encrusts or surrounds the stem and branches for about half an inch in length; it is ovoid and formed of minute brown hollow tubes variously intervoven. The cells, which are 
minute, stand a little from the surface, and are campanulate with even truncated apertures. I have been unable to refer this to any described species, and have therefore proposed to call it intertexta as descriptive of its appearance. As the peduncles are not ringed, it has been necessary to make a slight alteration in Johnston's generic character for its reception.

CAMPANULARIA L REVIS. R. Q. C. Arising from a creeping fibre; cells distant on long slender unringed footstalks, campanulate with patulous even apertures. Pl. si.

Hab. On stones and shells from deep water, Polperro.

This species is by no means uncommon, but to be seen must be examined in water while recent. It arises from a creeping fibre at irregular intervals, the footstalk is long, slender and dilates gradually into the cell; the cell is campanulate with a patulous and an even aperture, the polype has eleven long and slender tentacula.

It somewhat resembles the Clytia urnigera of Lamouroux pl. 5, fig. 6, but the cell does not swell so much, nor is the aperture so contracted as in that species.

* Siem composed of many parallel tubes.

HORSE-TAIL CORALLINE. C. Verticillata. Polypidom erect, tapering, branched; cells on long foot-stalks, arranged in a verticillate manner at regular intervals, funnel-shaped, with notched rims. Vesicles ovoid, on short peduncles, with small even apertures, rising from the trunk.

Horse-tail Coralline, with bell-shaped cups, Ellis' Coral,, p. 23 , no. 20, pl. 13, fig. a A. Sert. verticillata, Ellis and Solander's Zooph,, p. 50. Turton's Lin., vol. 4, p. 679. Stewart's Elem., vol. 2, p. 444. Clytia verticillata, Lamouroux's Cor. Flex., p. 202. Campanularia verticillata, Fleming's Brit. An., p. 550. Templeton in Mag. Nat. Hist., vol. 9, p. 466. Johnston's Brit. Zooph., p. 156, pl. xzii., figs. 3,4 .

Hab. On Pinna ingens, off the Deadman; not common. From one to seven inches high, stiff. The trunk is straight and tapering, as are also the branches, which are long and erecto-patent. The cells are bell-shaped with serrated rims, on long annulated footstalks, ringed at their extremities and plain about the middle, arranged in a verticillate manner at regular intervals, and generally about five in a whorl.

CAMPANULARIA DUMOSA. Climbing, hirsute; cells deeply tubular, nearly sessile; apertures even, unarmed, patent. 
Campanularia dumosa, Fleming's Brit. An., p. 548. Johnston's Brit. Zooph., p. 15\%, pl. 23, figs. 2, 5.

Hab. On stones, shells, and corallines; common.

The species varies so much in its general appearance, that specimens are frequently totally unlike each other. Sometimes it stands erect to the height of four inches and is very much branched; at others it creeps along the surface of a stone or shell and nothing but the cells are visible; and frequently it creeps up the stems of the Sertularix, the cells standing in relief irregularly round them. When erect and branched, it is somewhat bushy, and the trunk and branches are square. The cells, which are nearly sessile, stand in relief from all parts of the polypidom, as small linear tubes. But whatever shape it may assume, it is at all times readily distinguished by its cells; they are of a deep brown colour, deeply tubular and tapering towards the base; they are much stouter than any other of the genus, and the apertures are even, and unarmed, and the rim patulous and everted, like the aperture of a bugle.

CYMODOCEA. Lamouroux.

Generic Character: "Plant-like, cells cylindrical, varying in length, filiform, alternate or opposite; stem fistular, marked with rings below, plain above, and without interior division." Lamouroux.

CYMODOCEA SIMPLEX. "Stems simple, more or less waved, twig-like; cells alternate, long, and fliform; yellow fawn colour."

Cymodocea simplex, Lamouroux's Cor. Flex., p. 216, no. 35\%. Johnston's Brit. Zooph., p. 158.

I have obtained several specimens of this species, or something very nearly resembling Lamouroux's magnified figure, at pl. vii., figs. $2, \mathrm{~B}$, though unlike his figure of the natural size; and I am satisfied that all were nothing more than injured specimens of Laomedea Gelatinosa.

As this genus of Lamouroux contains only three species, each of which has a very doubtful existence, it may be entirely discarded.

\section{ORDER II.}

\section{ASTEROIDA}

The second order of British Zoophytes embraces but a few species, but offers considerable variations in character and appearance from any of the others. In the order last described, as also in the Helianthoid and Ascidian zoophyces, the polypidom or hard part is external, while in this it is 
situated interiorly: the exterior being occupied by the poly. pes and the fleshy crust. The general appearance of the order varies a great deal in the different families, each being dissimilar from the others; one is palmate and arborescent, another crustaceous and lobulated, and another plumous and linear elongated; but they may all be readily known by having eight-rayed starred depressions distributed over the surface. The character of the order is: Polypes compound, mouth encircled with eight fringed tentacula; stomach membranous with dependent vasculiform appendages at its base; anus none; iniestine none; reproductive gemmules produced interiorly. Polypidom, when existing, internal, horny or calcareous, free or rooted; polype mass arborescent, lobed or plumous; external crust fleshy, marked with star-shaped depressions of eight rays, for the polypes. All the species are compound, or composed of an aggregated series of polypes. The British species are distributed over the three families of Gorgoniada, Alcyonida and Pennatulida, of the last of which no species has yet been found in the Cornish seas; though Bellamy in his Natural History of South Devon mentions that Pennatula phosphorea has been found in Deron by Turton.

The Cornish species of the order, therefore divide themselves into two very natural groups; the Gorgoniada, being arborescent with an internal horny axis; the Alcyonida, encrusting or lobulated and destitute of an axis.

The form of the polype is common to the whole order and is the part by which it is characterized. In its expanded state it is a transparent truncated cone; having its base towards the polypidom, and the truncated extremity raised and surrounded by eight fringed tentacula. The sides being transparent, allow all the internal organs to be seen, and this transparent membrane is composed of two layers, one of which is continuous with the external investing membrane of the crusts and the other is continuous from the polypes to the cells and tubes, forming their internal serous lining. In the centre of the circle formed by the tentacula is the mouth, which opens by a short and narrow passage into the stomach. The stomach is membranous and hung suspended in the upper and central portion of the transparent cavity, but separated from the sides by an intervening space which is divided into compartments by eight transparent longitudinal septa. These septa appear to be formed of folds of the internal membrane of the polype and are attached to the outer surface of the stomach; but as they are longer than that organ, a portion of their internal edge is unattached and hangs loosely in the cavity beneath. At the base of the stomach is a minute orifice which appears to be guarded by a circular muscle, which opens into the abdominal cavity 
beneath. This orifice is surrounded by eight filiform appendages, which hang loosely into the abdominal cavity. Dr. Johnston says they "have generally been considered ovaries"* but he, as well as Grant and Edwards, doubts such a supposition, and considers them as subservient to the process of direstion; which so far as iny observations go, seems the most reasonable opinion. I have kept many in confinement, and watched others from the sea at all seasons, but have never seen these organs develope any thing resembling ova, which are known to be plentifully developed in other parts. The abdominal cavity, which occupies by far the largest portion of the polype, opens into the cell, which in its turn, opens into the tubes which traverse the fleshy crust.

When the polypes of the whole polypidom are fully expanded, the sight is among the prettiest that can be imagined, and more nearly resembles some aquatic Cactus in full bloom with transparent flowers, than a production of the animal kingdom.

Each polype, though exercising its functions as an independant being, is associated with all the others in the nourishment of the polype-mass. Beside this community of nourishment, there is also a community of feeling existing between the polypes; so that in recent and healthy specimens, any irritation made on one is perceived by ali, and a gradual withdrawal into their cells is the consequence. If, however, the specimen has been sometime removed from the sea, and not frequently supplied with good water, their powers of perception and action are considerably lessened, and they finally die in the expanded state.

The polype itself is exsertile, and when expanded may bo said to be in a natural state. In describing the transparent tunic forming the outer wall of the polype, it was mentioned that it separated into two layers at the rim of the cell; this point of separation forms the base on which the polype rests in its expanded condition. When it has retreated within its cell, the transparent tunic becomes invaginated "like the contracted horns of a snail," or like a partial inversion of the finger of a glove; and the edges of the cells are also drawn toyether into the star shaped depressions so characteristic of the Order.

The first of the two groups which occurs in Cornwall is the Gorgoniadce, of which two species only inbabit our shores; a third, which was found by Dr. Burlase in Mount's bay, must be noticed as having occured, but it was most probabiy foreign and cast on shore from some ship. The only species

* Mag. Zool. and Bot., vol. 1, p. 239. 
I have ever procured is the common Sea Fern, G. verrucosa, which is every where abundant. This species presents a great variety of form, two of which induced the late Mr. Sowerby to elevate them into distinct species, but for this there does not appear to be sufficient reason, as the variations most probably depend on the localities in which they grow.

The general appearance of the Gorgoniadce is stont, irregularly arborescent, netted, and more or less palmate or fan-shaped. They are composed of three distinct parts, which, although it is necessary to separate in description, are inseparably united to each other in a physiological relation, and constitute together the perfect animal. The parts are the crust or bark, the horny asis, and the central pith. The fleshy crust is always external and warted; when living, it is soft, fleshy, and of a light vermilion colour, which in death becomes very friable and changes to a yellowish white. It is covered more or less thickly and irregularly with small wart-like prominences, which have on their summits the star-shaped depressions for the polypes. The depressions have eight rays, answering to the number of the tentacula; but the circuniference of the star is very frequently encroached on for about a fifth of its extent by a fleshy lip which obscures several of the radii. The cells resemble an inverted cone in shape, and are smooth and white. The broadest part of the cone forms the aperture of the cell in the expanded state, and the apex is tubular and continued throngh the crust in an oblique downward and inward direction till it reaches the horny axis. The tubes vary in length according to the thickness of the crust, but do not inosculate as in the Alcyonium; after having reached the axis they pierce the membrane of the crust which lies in contact with the membrane of the axis, and pass beneath this membrane also in contact with the horn, and form the longitudinal rugæ which are so frequently observed. The crust of the branches is very frequently disfgured with large globular protuberances, similar to those figured by Ellis as occuring in the G. abietina * and which on dissection prove to be hollow, and to be formed by a separation of the membrane from the axis, forming a cavity which is partially filied with a whitish cellular substance. The surface of the fleshy bark, where it rests on the axis, is membranous and perforated by numerons oval orifices communicating on one side with the tubes of the polypes, and on the other with the rugr of the axis. If this membrane be examined under a microscope, especially if it has been allowed to undergo partial decomposition, it will

* Ellis and Solander's Zooph., p. 116. 
be found to be composed of light and dark lines, formed by larye numbers of irregular cellular bodies arranged longitudinally in various degrees of aggregation. When separated from each other, these cellules present une general lengthened form, terminating at either end in a point, at the base of which is a rim, resembling the nock and pointed stopper of a decanter. Between the two extremities, the body is straight, but has minute globular cells arranged sometimes in pairs, at others irregularly, and occasionally in rings round it. If allowed to undergo still further decomposition, these separate into smaller bodies of the shape of a Florence flask, which under still further decomposition, separate into minute globular cells, which form the ultimate component parts of the whole crust. Their union is of the most intinate kind, and before decomposition has begun, it is impossible to detect the points of union between them. Ellis, in his "Essay" on Corallines, has given a figure of a perfectly organized cell of the G. Placomus, which differs but slightly from those of the $G$. Verrucosa; but most probably they differ in every species.

The polypidom of the Hydroida, we have seen is external, but here a new and remarkable change has taken place, and it has become the internal solid skeleton which gives form and consistence to the whole. It is covered trom the root to all the branches with an investing membrane, similar to the periosteum of bones. This membrane, which is fibrous, is not equally demonstrable at all seasons of the year, or in all specimens. Though this appears to be independent of seasons, yet I have found it more clearly apparent about September, October, and Novernber, or at least my notices nore frequently refer to these than any of the other montiss. At those periods it is frequently so very loose that it may be stripped off; in the branches it is sometimes detached from the axis, and elevated into large cavities which are partially filled with a white granular matter; a section of these cavities therefore presents, first, the fleshy crust with its proper membrane, then, the investing membrane of the axis ralsed in contact with the crust, the white granular matter, and the surface of the axis itself. Under the microscope, this membrane appears striped and perforated with oval openings; on one or two occasions, in which the membrane was more than usually unattached and fine, the stripes appeared to be comsposed of cellules similar in shape and arrangement to those described in the membrane of the fleshy crust. The oval openings are continuous with the tubes of the polypes and the ruga of the axis, and doubtless serve for the trausmission of matter to the horny stem. This investing sheath is frequently so obscure as to bid defiance to a separation from its attachments; at this time the ruga generally are absent aud 
the surface of the axis dark, and polished. Ellis has made observations similar to these on this genus*, which have not been allowed to have their due influence in the formation of the theories of some of our physiologists.

The axis is solid, horny, fbrous, flexible and formed by a series of concentric layers. It varies in thickness according to age, and is more solid in the older portions than in the branches which are of a horny membranaceous texture. Though the thickness of the axis is in accordance with the age of the specimen, yet it depends for its existence on the soundness of the fleshy crust. For if from accident or the incrustation of corallines, the axis be denuded, it ceases to increase, while above and below the point of denudation it grows as usual. In a transverse section the concentric layers, in lighter and darker lines, are very observable, with the white central pith. This view bears a great resemblance to a similar section of the wood of an exogenous plant, but presents two remarkable deficiencies in the absence of the radiating medullary rays and cells which render the wood such a beautiful object for the nicroscope. The axis near the root is very compact and the circular layers consequently less distinct than higher up; in the branches it is merely membranaceous. In a longitudinal section the concentric layers are as apparent as in the transverse one and it very closely resembles a similar section in wood. It is fibrous and rends very freely. In different parts of this section white spots of a cellular substance are frequently observed irregularly distributed between the horny layers. This is most frequently observed about the root in the axillæ of branches, especially where two arise close to each other. In such a case I have frequentiy seen several successive layers of it with a few of the horny fibres between, and in a case now before me there are five very distinctly marked. The white substance, mentioned before as being found in the large cavities of the branches, so closely resembles these white spots in colour and texture as to point to a common origin for their production : a secretion or formation from the investing membrane. This appears to be the substance, supposed by Ellis to be the remains of a portion of the fleshy crust which had been enclosed between the horny layers. He says, "we frequently meet with layers of calcareous matter enclosed between the circles, which is evidently nothing else but the decayed flesh of the animal, which has been covered and enclosed by the subsequent growth of the same animal." This however, I believe is not the true explanation; in the case of the globular excrescences

* Ellis and Solander's Zooph., P. 69. 
of the branches, it is certainly not the case, as the deposit is recent and the crust entire; in the axilla of the branches it is very common to find sereral successive layers of the same so regularly deposited as to preclude the idea of such a fortuitous enclosure. This opinion, therefore, of Ellis's, appears to be arroneous, but is rather an error of deduction than of observation. In the lower portions of the stem and in that part near the roots, the cavities are frequently hollow or without any of the white matter; some are only partially empty, while in all the newer parts they are filled; on this point a very important question arises : Were these empty and partially empty cavities ever occupied by the white matter? If not, they differ from the more recent and superficial ones: If so, in what manner has it been removed? questions which very materially affect the doctrine of the inorganic nature of the axis. I consider these cavities to have been filled like the more recent ones and that the matter afterwards became absorbed. From this it will be seen that I am an advocate for the organic nature, and life of the axis; an opinion that will be further supported hereafter. I am quite aware that the opposite opinion is held by $\mathrm{Dr}$. Johnston, but with all respect for such high authority I confess that Lis facts and arguments are not of sufficient weight to make me alter my views; for the residual phenomena, for which his theory fails to account, are so great and important as to throw a very considerable doubt over it at least. Dr. Johnston quotes Lamark as saving that the axis under all its modifications is inorganic and formed by matter excreted from the polypes, which afterwards become solidified by affinity, this however is the result of theory rather than observation and can therefore have no weight when opposed to facts.

The pith is central, white and runs through the trunk and branches; and is sinaller and more compressed in the older than in the newer parts. Many persons, from the position and distribution of the pith taken in conection with the concentric layers of the axis, have considered it a vegetable stem. But there are several important discrepancies between the pith of a Gorgonia and an exoyenous stem, which have been noticed both by Ellis and Johnston. In vegetables the pith is continuous from the trunk through all the branches and is surrounded by a ring of vessels composed of tracheæ and ducts; in the Gorgonia it is not continued from the trunk through the branches, but each offset is separated by several layers of horny fibre and is in no way connected with the pith of the trunk. It is also divided at short intervals, in the Gorgonia, by transverse septa, and the branches appear as if 
grafted on the trunk; neither has it the zone of vessels so constant in the vegetable pith. In a transverse section of a recently formed part, the pith is found to be composed of irregularly sized cells quincuncially arranged; and in a longitudinal one, of cells very similar to those described as being found in the membrane of the crust, but smaller and whiter. It diminishes in size with age; in the youngest branches it is nearly twice as large as in the trunk; and near the root it is entirely absent; in an examination by the microscope, the newer portions are very apparently cellular, while the older parts, though of the same structure, appear as if destitute of the cells, from their being so closely pressed together by the surrounding horny texture.

The pith is the first part developed in the formation of new branches. The branches are formed irregularly on all parts of the axis, on the old as well the new portions, though most abundantly on the new. The mode in which the formation goes on, is best observed in a longitudinal section. This curious and important point $I$ have examined in a great variety of specimens, old and young, in sections of a h parts and at all seasons of the year. The tirst appearance of a branch is the formation of a white speck of medullary matter, sinilar in texture and appearance to the pith, and separated from the pith of the trunk by a few layers of horny fibre. At first, this spot is very small, but it soon enlarges and becomes triangular, having its base towards the centre and its apex towards the surface; it increases in size, and that portion of the axis that lies between the apex and surface becomes less till the point reaches the investing membrane; this is prolonged before it into a pointed prominence and constitutes the first outward mark of a branch. How the first point is formed $\mathrm{I}$ have been unable to determine, but it is evidently the result of an action going on in the axis itself; and has not the least connection with any of the accidental patches supposed by Ellis to be portions of the fleshy crust. In proof of this it may be observed, that in the longitudinal sections of seventeen specimens the bases of the pith of all the branches were situated at about the same distance from the pith of the trunk, and the pith of all observed in the process of formation, was similarly situated. Whether new branches were forming in the old or new parts, they all began alike and passed through the same process; so that their formation is the result of an action going on in the axis, rather than of accident.

In the Gorgoniadæ which grow near the shores and off headlands, which beeome so much more bushy than those from deeper water, the branches, which are long and cross each other, become united at their points of crossing; and in some instances for half an inch in extent. On examination, this 


\section{1}

union is found not to exist only at the fleshy crust, or at the elges of the horny axis, but throughout the extent of the opposirg surfaces. In some cases the union has taken place as soon as the branches came in contact; in others, and by far the most numerous, the axis has been rubbed half through and then nnited. On one occasion one branch had become interweaved with three others, and where they touched they became united in the crust and surfaces of the worn axis. So that the axis must, I think, be allowed to posses a vital power, a power which enables it to form new branches in its own texture and to unite any points which may have been made bare by the friction of others. If the axis be inorganic and extravascular, these phenomena are to me inexplicable.

The axis is frequently denuded for a considerable extent, either from accident or the incrustation of Corallines. From the soft and uneven nature of the crust it is very liable to be infested with parasitic animals, such as the Cellepora pumicosa, many species of Sertularia and Tubulipora; different kinds of Lepades of which the L. Scalpellum seems to prefer it to any other situation.

The Gorgoniadia are always firmly rooted to the rocks and stones on which they grow; and the crust and axis both extend themselves over the surface and produce a firmer rooting. The pith does not extend into the root. The layers of which the expanded root is formed, are more membranaceous, more loosely united, and not so solid as the layers composing the trunk aud branches.

The second division, destitute of an axis, comprises the Alcyonidae of which there are three recognized British species, belonging to two genera. One of which, the Cydonium Mulleri of Flening and Johnston, has since been removed from the Asteriod Zoophytes, and placed among the sponges of the genus Geodia. In my paper on the sponges of Cornwall, published in the transactions of the Falmouth Polytechnic Society," I expressed an opinion that the Cydonium would occupy a place between the true and a-polypus zoophytes. Such an opinion was formed from the inspection of only one specimen and was therefore liable to error; but $\mathrm{Dr}$. Johnston in his valuable work on British Sponges is of the same opinion; so that the native species of this division amount now only to two. Under the Alcyonium digitatum two species have I think been confounded but will here be found separated as Al. sanguineum, from its colour.

The form of the Alcyonium is liable to great variations, which are chiefly dependent or the age of the specimen; 
they may however be reduced to three primary onos, all others heing mere variations of them. Each form has a very appropriate name applied to it hy the fishermen. which though far from elegant is very expressire. In its youngest state it is merely an encrusting film of about a line in thickness and is called Sea Scruff; in the next stage is has become a simple lobe or fingerlike prolongation, and is then called paps or teats. In its most perfect state it has becomo large and irregularly lobulated, and is then called dead man's hands, or dead man's toes. The surface is very coriaceous, filled with small calcareous spiculæ, and marked witb starshaped depressions similar to those of the Gorgonia. In a longitudinal section of a full grown specimen, the cut surface is found to be composed of a complicated kind of net work with lozenge-shaped meshes. From the cells in which the polypes rest, tubes are prolonged throughout the mass, and freely communicate with each other. Though one tube does not communicate with all the rest, yet there is such an exten. sive interchange of communication, that such nay almost be said to be the case. They open into each other chiefly by inosculation; but the tubes are perforated in all parts by minute openings which lead into small canals. These canals cross the spaces between the large tubes and join similar canals from other parts; these are also perforated and send off capillary ducts which traverse the meshes formed by the tubes in all direction; this capillary net work is pervaded by the jellylike flesh of the polype mass which encloses the spiculæ des. cribed by authors, If coloured water be given to the polype, which will not irritate, it first passes into the stomach and from thence, through the opening at its base, into the abdominal carity beneath, into the spaces formed by the septa and from thence into the tentacula which then become distended. In passing downwards it goes through the base of the cells into the tubes, through their openings into the canals and from thence into the capillary ducts and surrounding gelatine, by which the mass becomes swollen and enlarged as it is commonly found.

The tubes are formed of two, if not of three tunics, which are subservient to different functions, but mutually assist each other. The inner or lining membrane is thin, transparent, and continuous with the lining membrane of the cell and the outer transparent part of the polype. The second is cartilaginous, with the fibres laying in a longitudinal direc. tion; this being elastic allows of a certain degree of extension, and when the distending force is lessened, enables the tube to regain its former length. Beside these, and between them, I have on several occasions found minute circular libres which are white, and I believe, muscular, and assist the lon- 


\section{3}

gitudinal coat in retaining the tubes to their proper size. The first or inner tunic appears to be of a serous character, and to resemble the lining membrane of arteries; but has this character in addition, that it is the sole seat of reproduction in the order.

The spicula are dispersed irregularly throngh the substance of the polype mass; near the surface far more sparingly than towards the centre, where they are more closely aggregated. They are very irregular in shape, but yet all possess a character in common. In many cases they closely resemble the bodies described in the Gorgonia, and have a similar formation. Some are $\boldsymbol{K}$-shaped in various disfigurations of its parts. By maceration they readily undergo decomposition, and are then found to have the same cellular composition as the bodies in the Gorgonia. The cellules are very closely and intimately connected, yet the connection is readily broken by maceration or weak acids. Though they are thus diffused through the fleshy gelatine with but very little organic connection, yet from their composition they appear to be the result of some vital action. Dr. Johnston considers them as the first appearance of a polypidom or axis, he says "that it would not be difficult to trace them through all their gradations to the horny flexible axis of the Gorgonia." Such, from the observations made on the pith and investing membrane of the axis, and the membrane of the crust in the Grorgonia, may possibly be the case; but I rather hesitate to consider them similar to the raphides of plants, or the spicula of sponges.

Reproduction occurs in this order only in one way, by the internal generation of gemmules or ora. There is no particular set of organs appropriated to this function as in the higher animals; nor is there, as in the Hydroida, a periodical developement of ovarian resicles. The function appears to be of a diflusive kind, and is common to all parts of the lining membrane of the tubes, and according to authorities, to the walls of the abdominal cavity.

The manner in which the ova are developed is best observed in a transverse section. In a natural state the calibre of the tube is circular, but $w$ hen ova are about to bo developed, a segment of the circle is slightly bulged towards the centre. As developement progresses, the buiging increases and becomes more and more circular, till it becomes quite globular and lies on the tube as a tangent. The ovum is held to the lining membrane by an umbilical cord, which is soon clearly to be noticed; this gets more and more attenuated and is finally absorbed or ruptured and the orum is left at liberty in the tube. From the $\nabla e r y$ earliest period at 
which ova are observed to be developed, their surfaces are covered with numerous minute vibratory cilia which are in constant action; these. when the ovum is free, whirl it about in a very rapid manner from one part of the tube to another, and at length into the abdominal cavity. Here it moves about from part to part, sometimes to the orifice at the base of the stomach, which inmediately contracts to prevent its escape; at others it wanders into the chambers formed by the septa and to the base of the tentacula, and then again returns to the base of the stomach. At length it passes through the orifice into the stomach, where it is considerably retarded in its action by the contraction and pressure of the gastric surface. After passing the stomach, it escapes by the mouth into the surrounding water. When escaped it appears as if re-invigorated, and moves about with an energy and activity truly remarkable. From the globular form, which they have when they escape, they change first to an oval, but vary in different instances and at different tinies. The changes are sometimes rapid, and appear almost voluntary; sometimes they are oval, at others they have an hour glass contraction, and occasionally have rounded heads with a tail like prolongation, and thus they vary to an almost unlimited extent. Having at length found a spot on which they rest to become fixed, fibres pass out from the base to serve as roots, and the other parts undergo a remarkable alteration in colour and appearance, becoming more elongated, opaque, and dull, and the flesh appearing on the surface; the horny axis in a very rudimentary state appears before it has attained one line in height; such is the mode observed in the Gorgonia. The young of the Alcyonium differs from this, by diffusing itself into a thin crust. Thus these curious creatures, first moving about with activity and the irregularity of almost voluntary motion, then becoming fised, rooted, and branched, present an instance of metamorphosis as remarkable as any fabled by the Roman poet. When the ova first appear they are of a very light colour, but soon acquire a deep orange tinge. Under the microscope they appear opaque, but with a good light they ase found to have a transparent zone. Their production is entirely independent of any active influence of the polype; by means of the polype an abundant supply of renovated water passes over the ova and so keeps them in a healthy condition. Both in the Gorgonia and Alcyonium, the whole process of reproduction is so sinilar, that it is difficult to draw a distinction between them. The ovaria and oviducts, described by Cavolini as being found in the Gorgonia, I have never detected; and the ova instead of escaping at the base of the tentaculia, as mentioned by him, I have found to escape 
by the mouth, as in the Alcyonium. According to Dr. Johnston, Spix figures the ova united into a bead-like string, which, from their manner of formation is impossible. In this respect also, the figure of the reproduction of the Hydroida given by Jones in his "Outlines of the Animal Kingdom" is erroneous.

Though this order can boast but of very few native species, yet further observations will probably find that several have been confounded under one name.

It has been remarked above that no specimen of the Family of Pennatulide, or Seapens has yet been found in our seas; as however an instance has occured in Devonshire, I here add the family and generic characters to enable observers on the different parts of our shores, to detect them if any should be taken.

\section{PENNATULID AE.}

"Polype-mass free, pennated, carnous, the skin spiculiferons; axis bony, simple continuous: Polypes arranged along the margins of the pinnce."

PENNATULA.

Generic Character: "Polype-mass free, plumous, the shaft sub-cylindrical, naked beneath, pennated above; pinnce tworanked, spreading, fattened, and polypiferous along the upper margin."

VIRGULARIA.

Generic Character; Polype-mass free, linear-elongate, supporting, towards the upper extremity, sessile lunate lobes embracing the stem obliquely, and bearing a row of cells m their margins."

\section{GORGONIAD A.}

Polype-mass fixed, arborescent, the axis corered with a thick cretaceo-gelatinous celluliferous crust; poly pes scattered over the whole surface. Johnston.

\section{GORGONIA. Linnæus.}

Generic Character: Polype-mass rooted, arborescent, consisting of a central brown horny axis, with an external yellow fleshy crust, warty, bearing the polype cells.

WARTED SEA FAN. G. Placomus. "Irregularly branched, the branches disposed in a dichotomous order and a flattish form, cylindrical, warty; cells protuberant, conical, surrounded at top by little spines." Ellis. Pl. 12, fig. 2 .

Warted Sea Fan, Ellis' Coral., p. 67, no. 1, pl.27, figs. a A, 1, 2, 3. Gorgonia placomus, Ellis and Solander's Zooph., p. 86. Turton's Lin., rol. 4, p. 64j. Stewart's Elem., vol. :2, p. 430. Fleming's Brit. An, p. 512. Johnston's Brit. Zooph., p. 183, pl. 25, fig. 2. 


\section{6}

Hab. "Coast of Cornwall." Ellis.

"This Sea Fan is of a reddish brown colour;" "has its branches disposed in a dichotomous order and a flattish form, they bend irregularly towards one another, but rarely unite. Their mouths are conical, project, and are surrounded on the top by little spines. The bone or support is nearly of the substance of wood." Ellis and Solander.

This species is found abundant in Norway; but Ellis must have been very fortunate to obtain a specirnen on this coast; for after examining many scores of Gorgoniæ from the English channel, I have not seen a single specimen; and Mr. Peach, of Goran, informs me that he has never seen a specimen, so that on the south coast at least it is very rare.

SEA FERN, OR SEA FAN. G. Verrucosa. "Much and irregularly branched, branches spreading laterally, cylindrical, flexuous, barked when dry with a white warted crust; segments of the cells unequal, obtuse." Cole. Pl. 12, fig, 1.

Keratophyton flabelliforme, cortice verrucosa obductum, Raii, Synop. Stirp., vol. 1, p. 32, no. 1. Warted Sea Far, Borlase's Nat. Hist. of Cornwall, p. 238, pl. 24, fig. 1. Gorgonia verrucosa, Ellis and Solander's Zooph., p. 89. Turton's Lin., vol. 4, p. 648. Stewart's Elem, vol. 2, p. 430. Fleming's Brit. An,, p. j12. Johnston's Brit. 'Zooph., p. 182, pl. $x \times v_{0}$, fig. 1 .

Hab. Abundant along the whole of the sonth coast; Pednankern-rock, Mount's bay. Borlase. "In Insula St. Georgii prope West-low comitatus Cornub." Raii, Synop. Every where common.

The general appearance of this species is such, that it cannot fail to be immediately recogrized. Yet different specimens differ so much among thernselves that some authors have constituted them different species; the G. Verrucosa and Viminalis of Sowerby. Having specimens of both marked by Mr. Sowerby, I have been enabled to examine them under very favourable circumstances. Having compared together upwards of seventy specimens of each, of all sizes, I am inclined to agree with Fleming and Johnston that they are but variations of the same species.

Its form is arborescent, stout, and fan-shaped; externally it is fleshy, of a beautiful red flesh tint, tubercular and marked with star-shaped depressions; internally it is densely horny, with a minute central pith traversing the horny axis. It varies in height to twelve inches; in breadth to seventeen. When living, the external flesby crust is soft, and of a flesh tint; when dead it becomes dry, calcareous, friable and of yellowish or dirty white colour, The prominent tubercular 
warts which are so thickly distribated over the crust, are the situations of the polype cells, in which the polypes lie concealed beneath the surface. The depressions, which are star-shaped, bave always eight rays; but a portion of the circumference of each star, is frequently encroached on for about a fifth of its extent, by a large fleshy lip; this is the case as frequently in one variety as the other.

The varieties may be considered the two above refered to; but there are specimens of such a mixed character that. they may be refered to either one or the other with equal propriety. The G. Viminalis is stouter than the other, more robust, less branched and more fan-shaped, and grows in deep water from six to ten leagues from the shore. The $\boldsymbol{G}$. Verrucosa is more slender, more and irregularly branched, spreading laterally from the fan like plane, and grows nearer the shore and off the head lands. From these circnmstances, it appears probable that the variations depend on the localities in which they grow. Those near the shore, being disturbed by a variety of currents become bushy, while those from deep water distant from the shore, being subject to the two currents of ebb and flow, acting in parallel lines, assume the fan-shape.

The branches are frequently infested with various corallines, the Plumulario, Sertularice, Alcyonium, \&c.; Lepades, especially the L. Scalpellum; and are liable to globular excrescences, which are found to be composed of, the fleshy crust, and the horny membrane which invests the axis, which is raised and in connection with the crust, leaving the axis bare, forming a cavity which is frequently partially filled with a whitish medullary matter; this has been mentioned before in the introductory observations to this order, to which the reader is refered for further information.

This species is among the commonest on our coast; from Plymouth Sound to the Land's end and the Irish sea, it is to be found at almost all depths.

VENUS' FAN. G. Flabellum. This species grows in the form of a fan of net work, with its branches compressed; the flesh is yellow, sometimes purple or brown, with small mouths placed irregularly, having polypes with eight tentacules; the bone is black, horny and slightly striated on the large branches.

Flabellum Veneris, Ellis' Coral., p. 61, pl. 26, fig. A. Borlase's Nat. Hist. Corn., p. 238. Turton's Lin, vol. 4, p. (i51. Fleming's Brit. An., p. 511. Johnston's Brit. Zooph., p. 185, vignette no. 19, p. 161.

The only authority for making this Cornish is Dr. Borlase, who at page 238 of his Natural History says, "It was 
picked up in Mount's bay after a storm." Most probably it was foreign, for I have not heard of another specimen baring been taken, and this was dead when found. It has been found near Leith by the late Mr. Mackay, and Mr. Neil, according to Dr. Fleming who saw the specimen, and says it had the appearance of being fresh and recent.

\section{ALCYONID W.}

Polype-mass fixed, coriaceous or somewhat carnous without any distinct axis, but strengthened by variously disposed calcareous or siliceous spicula; polype cells sub-cutaneous, scattered over the surface like stars.

\section{ALCYONIUM. Linnæus.}

Generic Character: Polype-mass lobed, or incrusting, spongious, the skin coriaceous, marked with star-shaped pores; Interior gelatinous, netted with tubular fibres and perfo. rated with longitudinal canals, terminating in the polype cells, which are sub-cutaneous and scattered: Polypes exsertile.

TEATS, OR DEADMAN'S HAND. Alcyonium Digitatum. Polype-mass lobed or encrusting, of a fleshy spongy nature, flesh coloured, wrinklcd, marked with star-sbaped pores even with the surface. Pl. 13, fig. 1.

Alcyonium ramoso-digitatum nolle, astericis undiquaque ornatum. Raii, Synop., vol. 1. p. 31, no. 1. Deadman's Hand, or Deadman's Toes, Ellis' Coral., p. 83, no. 2, pl. 32, fig. a A. Alcyonium Manus Marina, Blumenbach, by Gore. Lobularia digitata, Fleming's Brit. An., p. 515. Alcyonium digitatum, Eilis and Solander's Zooph., p. 175, pl. 1, fig. 7, of the polype. Turton's Lin., vol. 4, p. 652. Templeton in Mag. Nat. Hist., vol. 9, p. 470. Harvey in Mag. Nat. Hist., vol. 1, new series, p. 4\%, figs. 56 and 57 (unlike). Johnston's Brit. Zooph., p. 188, pls. xxvi and $x \times r i *$. Al. Lobatum, Lamouroux's Cor. Flex., p. 336, pl. xii., fig. 4 and pl. siv. Lobularia Digitata, Roget's Bridgewater Treat, vol. 1 p. 162, fig. 56. Jones' Outlines of An. King., p. 27, fig. 5 .

Hab. Abundant on shells and stones from deep water. Polperro, Goran, Fowey, Meragissey, Whitsand bay, \&c.

This is a very common production on all parts of our shores, at all depths, and varies in height from a thin incrustation to ten inches. It is most familiarly known to our fishermen when it occurs as large, lobulated, fleshy masses, of an orange colour, attached to stones and shells. But it occurs under a variety of fornis, to each of which the fishermen give a distinctive name. In its early stages it appears as a thin yellow incrustation of about the eighth of an inch 
in thickness, and marked with stellate depressions, beneath which the polypes lie hid; in this state it is called Sea Scruff. In a more advanced state, the crust gets thicker and rises into nipple-like processes, in which state the fishermen call them Teats, and in the north of England Cows' paps, each of which is characteristic of its form. As it still further advances in growth, it becomes an irregular lobulated spongy mass, and in this state acquires the not very elegant name of Deadman's toes or Deadman's hands.

Externally it is of an orange colour, and is marked with stellate depressions of eight rays, answering to the number of the tentacula of the polype. The skin is tough and coriaceous, with minute calcareous points. In a longitudinal section, the substance is found to be composed of tubes which proceed from the base of the cells through the mass and variously anastomose with each other; so that an interchange of communication is kept up between each polype and the whole mass. From this frequent interchange of communication, the whole mass has a hard spongy texture. The spaces between the inosculating tubes, are flled up with a fine tubular net work; in which is diffused a semi-transparent gelatinous substance; having imbedded in it serrated irregular spicula. The tubes are composed of two, if not three layers of tissues; a cartilaginous, muscular, and membranous tunic, each of which also assists in forming the base and sides of the cells.

The polypes are semitransparent and conoidal; the apex is truncated, the centre of the surface is occupied by the mouth, and the circumference surrounded by eight fringed tentacula. The mouth opens into a membranous stomach which is freely suspended in the transparent tube forming the body of the polype. The space between the stomach and the external wall of the animal, is divided into longitudinal compartments hy eigint thin membranous septa, which unite the stomach and exterual parietes together, and keep the stomach in situ. At the base of the stomach is an orifice, which from being larger at one time than another, is probably of a muscular nature; around this orifice are suspended eight opaque filamentous threacis which hang loosely in the cavity below. These threads, are probably subservient to the function of digestion, and partake of the character of a liver. The cavity in which these filaments are suspended, which may be considered as the abdomen of the animal, cummunicates with the tubes which traverse the polype mass. The ova, which are numerous, are formed in the sides of the tubes, and escape through the opening at the base of the stomach, into that cavity, and from thence, through the mouth into the 
surrounding water; this subject is considered more fully in the introductory notes to the order.*

The figure of Alcyonium Lobatum of Lamouroux apparently belongs to this species; but it is so faintly execnted, that it is uncertain whether it belongs to this or another; I believe it belongs to this, though not very characteristic; a character which may be applied to many other of his figures. The figure of the Cydonium Mulleri in Jones' " Ontlines of the Animal Kingdom," p. 27, fig. 5, also probably belongs to this, though I quoted it in the paper in the Polytechnic Report as the true Cydonium. Johnston's figure is good and characteristic of the expanded state. The tentacula of the polypes are liable to such a variety of appearances, depending on their partial or complete expansion, that we ought not to decide on specific differences hastily on such grounds. The differences between the different polypes figured by Ellis are great, and they differ from those of Lamouroux which correspond to the polypes of this species, and from Jolnston's which most closely resemble those that I have observed.

ALCYONIUM SANGUINEUM. Encrusting, fleshy, and deeply lobulated; lobules elongated cylindrical, and extending nearly as low as the base; of a deep blood red colour. Polype-cells depressed, yellow, small, with eight rays, numerous. Skin coriaceous. Pl. 13, fig. 2.

Of this species I bave procured only a single specimen and that, not far from land; in general appearance it resembles the last species the Alcyonium digitatum, but differs from it in several important particulars. Its surface is rather rough, coriaceous, and occupied by numerous spicula. The starshaped depressions, which are numerous, are slightly depressed, yellow and marked with eight rays. The cells, which are imbedded, are inversely conical and terminate inferiorly in. long canals, which pass irregularly through the fleshy polype-mass, and opening into each other in all directions give the substance the appearance of irregular net work, the meshes of which are filled up with minute tubes, a gelatinous substarce and spicula. Thus the internal anatomy resembles that of the Al. digitatum, but is smaller and more delicate. The colour externally is of a deep blood colour and internally is but slightly lighter. The lobes differ very considerably from those of the $A l$. digitatum; but as a specimen of that species was procured from the same locality and at the same time a comparison may be instituted between them. The protuberances, in the Al. digitatum, are, gene- 
rally, not very numerous, do not divide low down, but arise from the sides and edges of the larger lobes: are always stont, somewhat compressed, and more closely resembling the teat of a cow than the human finger. In the present case, the lobes are very numerous, and divide nearly as low down as the base; they are elongated, cylindrical, and very nearly resemble the little finger, both in shape and size. As the specimen was very nearly dead when I first saw it, the polypes can of course be but very imperfectly described. They seemed very similar in shape to those of the Al. digitatum, but were smaller and semi-opaque; the tentacula were eight, fringed, and of a pinkish tinge, with a red band beneath, encircling them: the various orifices could not be observed. The spicula are numerous and ir regularly arranged; they are linear-elongate, pointed at both extremities, with uneven, or granular spaces between; sometimes they are simple and at others united into K-shaped bodies, and occasionally wanting one or other of its members forming an imperfect $\mathrm{K}$.

That this is not a variety of the Alcyonium digitatum, seems almost certain. Having had opportunities of examining that species in many thousand instances, from all parts of the Cornish coast, from near the shore to mid channel, and in all stages of growth, I may therefore be supposed to be familiar with it, yet on my own mind there is no doubt of its being distinct; and such also is the opinion of others who have examined it.

ORDER III.

HELIANTHOIDA.

This order contains the largest and most brilliant species to be found on our coast, and is therefore the most likely to attract the attention of casual observers. All naturalists who have written on them, describe them in such glowing terms as seem more fitted for the regetable than the animal kingdom; yet when many of them are examined, such descriptions may be sad, rather to have fallen short of, than to have exaggerated their beauties. Their interest to the naturalist, however, is founded on other and more important grounds; in them he recognizes the British representatives of most of those wonder working animals of the South Seas, by which the coral reefs and islands of that region are reared, and by which perhaps, continents may eventually be formed. It is true our shores cannot boast of such magnificent specinens as are brought to this country by our navigators and merchants, and that the only calcareous species we have is a 
small and insignificant one ; yet the researches of the Geologist have proved, that in the early ages of our globe, species, if not identical with those of the Sonth Seas, yet equal to to them in size and heauty, once inhabited our shores. In the limestone rock of Devon, and in some of the slate rocks of our southern coast they are common and well marked.

The Cornish species are not numerous, are mostly soft, fleshy, and single animals; there being but one calcareous, and one compound species.

The most common and most numerons genus is the Actinia of which a representative may be found in the common brown Anemone, every where to be found between tide marks, in pools, and on the shelving sides of rocks. The character of the order is: Polypes compound or single, free or attached, fosculous; the body regular with a circular periphery, concractile, internally divided into numerous spaces by perpendicular muscular septa; mouth superior and central, encircled with one or more series of tubular tentacula: stomach membranous: anus $O$ : ovaries and caca placed in the septa between the stomach and skin.

The first genus we shall notice is the Actinia, which, in its contracted or quiescent state is hemispherical or sub-conoidal, with a central superior orifice or depression; the surface of its body is smooth and shining, or glandular and warty. In the expanded state, the apex of the cone becomes unfolded into a flat disc, having an oral aperture in the centre, a plain surface beyond it surrounded by several circles of tnbular tapering tentacula, beyond which is a free plain rim. It is this free edge which infolds over the tentacula and hides them from view in the contracted state. This complete retraction of the tentacula constitutes the difference between the Actinia and Anthea, two genera, which are alike in all other particulars. Thus when the animal is expanded it bears a great resemblance to the pictorial representations of the sun, and from which the name of the order is derived. It will be unnecessary to enter further into the anatomy of these creatures, than will suffice to convey a general idea of their form and those points of their physiology which may be considered popular. Those who desire to enter further into the subject, will find an elaborate paper on it in the Leeds Philosophical and Literary Transactions by $\mathrm{Mr}$. Teale, and to the accuracy of which I can bear testimony.

The body is hollow; the mouth opens by a short, wide passage into the stomach. The stomach is large, membranous, semi-transparent, plaited and divided into two equal parts by longitudinal furrows; these are formed by the adhession of the stomach to two solid fleshy septa through 


\section{3}

their whole length. By these bands, it is, that the stomach is prevented from being entirely excluded, when the animal evolves it into the inflated membraneous lobes, which it often does in a state of hunger, and when the water is impure. The stomach is a shut sac, and has only one orifice both for the receiving of its food and ejecting the fæcal remains. Its inferior portion is however punctured with minute orifices and sometimes there is an orifice at its base larger than these, which seems analogous to the orifice in the asteroid polypes; though on some occasions I have failed to make it out, yet from the sphincter character it must have, it is probably closed, and hence not always apparent. It appears to be through this opening that the young are excluded and the white threads so often ejected with the stomach. The space between the stomach and sides of the animal is divided into numerous compartments by unequal longitudinal septa. They are of a muscular texture and unequal both in length and breadth; some reach from the sides of the animal to the stomach, others only reach portions of the way; some procede from the base to the roof or oral surface, while others reach hardly so far, hence Dr. Johnston says they radiate like the gills of a mushroom to its stalk, which will convey a good idea of the arrangement. 'These lamellæ being muscular, greatly assist the animal in its various actions, and are the cause of the great variety of contortions which it sometimes assumes. These interseptal spaces are occupied by the ovaries and long white filaments which by some have been considered oviducts.*

The ova are exceedingly numerous, and are enclosed in a transparent membrane which at one edge hangs free, and being double encloses the ova, and afterwards the two layers come into contact and become attached to the edges of the septa and form a mesentery which retains them in situ. Afterwards the two layers again separate, pass on each side of the septa and line them and the whole cavity, including the surface of the stomach and the tubes of tentacula; forming in fact a peritoneum, and performing its functions. The ovaries are attached to the whole length of the septa, and lie in horizontal folds; sometimes they are attached to each partition, and sometimes one or more are missed, and occasionly two ovaries are found on one, so that a great variety occasionally occurs. From the ovaries, according to Spis, oviducts proceed to the base of the stomach; according to Blainville, to the labial rim; and according to Delle Chiage, to the tentacula, for the expulşion of the ova. 'These orgatls

* Sharpey, Cyc. Anat. and Phys., p. 611. 
I have never seen, unless they are the white threads, which Sharpey and Jones also describe as oviducts, but which appear to have no connection with such a function. The white filaments are convoluted, of equal thickness, small, smooth, and fibrous; if hollow, the cavity must be exceedingly small, for I have never heen able to detect it. They are clothed with the peritonenm and consequently are fastened or held by a mesentery similar to the ovaries. Their functions are unknown. They are frequently ejected through the stomach and frequently are forced through the sides of the animal, as may be witnessed in the $A$. dianthus. The tentacula are tubular and tapering towards the extremity; and the tube is terminated by an orifice, which appears to be guarded by a circular muscle to prevent the ejection of the water when pressed on by the motion of the animal. The whole lengtb of the tentacula is however pervaded by circular fibres, and hence the reason they are sometimes observed to contract more in one part than another. The orifices of these organs open into the cavity which contains the convoluted ovaries, and hence the water which distends the polype, passes readily from one part of the animal to another. In the Anthea cereus, these organs are very liable to malformations both of deficiency and excess. They appear to be very liable to disease, but whether from disease or accilent, if any part be injured it is soon thrown off and the tentacula appear truncated. Sometimes a great many are thus injured, but most commonly only one here and there. Scarcely a specimen, however, can be found, but is more or less thus injured. Young ones are constantly sprouting up from between the old ones, and are always to be found from the size of a mere tubercle to the perfect organ. Some tentacula are branched in a dichotomous manner, but more have a finger like process sprouting from the side. Though these malformations are of very rare occurrence in other species, yet in any one if a tentacle be injured or clipped, it very readily re-grows, and the experiment may be successfully repeated to any number of times; but like all reproduced parts, it is very liable to be re-formed, in a double manner; and as the tentacula of the Anthea cereus appear to be very susceptible of injuries, this will account for the great prevalence of malformations in that species.

When these creatures are expanded they very closely resemble a flower both in form and colouring; hence the public in most countries have given them the name of Sea flowers as expressive of their general appearance. In English we have Sea carnations, marygolds, anemonies, aud daisies; their scientific names are expressive of the same character, and all who may have examined them, will think them worthy of the comparison. 


\section{5}

The studded Sea flower in its most perfect state has its mouth surrounded with several rows of unequal tentacula, which are inarked with bars of carnation, lake, brown, and white, in such a manner that each forms a succession of circles round the mouth, and present a scene of such remarkable brilliancy and beanty, as few flowers can equal. The Sea daisy is not so brilliant as the one just mentioned. It has however its patches of brown, yellow and flesh colour so beautifully and harmoniously blended, its festooned circumference so surrounded by a circle of short variegated tentacula, forming a fringe of such "inimitable beauty" as fairly to entitle it to the ephithet "Actiniarum pulcherima," given it by Müller. They are not admired, simply because they are so far removed from common observation, as to be but rarely seen. Their great beauty, the certainty with which they are said to foretell a change of weather by the opening or closing their tentacula, and their great tenacity of life, by which they may be kept in confinement for years with an occasional change of water, would point them out as a pretty, agreeable and useful variety to the ornaments for the boudoir. With but one exception, all of the Actiniidee. are single or furmed of only one polype, and locomotive. But the different species rary a great deal in activity; the most active perhaps is the Anthea cereus, which is the most delicate and shortest lived of all. The studded sea flowers and sea daisies, in a state of nature rarely move from the spot in which they have once fixed themselves. Some of the former I have known to retain their situations for five years; but when in confinement, they very freely move to all parts of the vessel. When quiescent they very firmly adhere by their bases to the stones on which they rest. This adhesion is commonly said to be effected by means of a glutinous secretion from the base; but never having found a secretion of sufficient tenacity to account for the firmness of their hold, the explanation must be sought for in some other way. It is however readily found in the muscular foot disc, which in contracting elevates the centre and a vacuum is formed, the circumference being closely in contact with the rock or stone. A common and familiar illustration mav be found of the way in which it is done, in the school boy's leathern sucker. This is also the way in which it is effected in the Lucernarice, and most probably in all the others. If the edge of the fout be raised with the nail, the whole is easily detached; if fresh water be poured on them they immediately die and then the adhesion is very little; in the last place the animal can loose its hold at pleasure and move fron place to place with a gentle gliding motion, but the moment it is attempted to be removed it regains its former firm hold. 


\section{6}

Another mode of progression is by means of their tentacula. This is perhaps the most rapid of alt; but I have never seen any of the animals voluntarily make use of it, except the Lucernarice; I have placed them on the oral disc and they have travelled with ease and comparative rapidity by using the tentacula, especially the Anthea, which is capable of more variety of action than any of the others. They are said also to distend their bodies with water and allow themselves to be washed about by the random motions of the sea; this I have never seen.

This class of animals, so entirely destitute of solid parts whereby they might perform their various muscular actions, forcibly points out the resources of nature in overcoming difficulties apparently insurmountable. Being so universally soft and gelatinous, no point is offered as a fulcrum on which the muscles can act; but yet a great variety of definite actions are performed with readiness, and are entirely under the guidance of the animal. When they are about to exert themselves, they imbibe water and distend themselves to any extent they please. In this distended state the orifices of the tentacula and all other means of exit are closed, and thus, when the muscles act, they exert themselves on the contained water, which, by resisting, becomes converted into a fulcrum as efficaceous as it is simple. This mode of compensating for the want of solid points for muscular action is greatly diffused through the animal kingdom; instances of its exclusive use are to be found in the Physalia, or Portuguese man of war, where however, air is used instead of water; in the feet of the Asteriada, and in fact in all the Echinodermata, and in a rudimentary state, in an organ of the highest animals and in man. But this which is so rudimentary and nearly disappears in the higher animals, is the sole means of exertion in many of the lower, and the mode of change is at once simple, effective and elegant.

The appetite of these, like most of the rayed animals, is of the most ravenous kind; though they can, and have been made to fast for twelve months, yet they are ready at all times for such food as chance or design may offer; shells of the largest size, or the smallest insect are equally welcome. The difficulties into which this great appetite frequently throws them are of the most extraordinary kind. Dr.Johnston mentions one of the Actinia Gemmacea; the animal originally measured about two inches in diameter, but had contrived to swallow a shell (Pecten maximus) of the size of an ordinary saucer. "The shell fixed within the stomach, was so placed as to divide it completely into two halves, so that the body, stretched tensely over, had become thin and flattened like a pancake. All communication between 
the interior portion of the stomach and the mouth was of course prevented, yet instead of emaciating and dying of a hytropliy, the animal had availed itself of what undoubtedly had been a very untoward accident, to increase its enjoyments and its chances of double fare. A new mouth, furnished with two rows of numerous tentacula was opened on what had been the base, and led to the under stomach: the individual had indeed become a sort of Siamese twin, but with greater intimacy and extent in its union." This case also illustrates the power these creatures have of sustaining injuries of the most formidable kind, with apparent impunity, and which is exceeded only by the Hydra. They have been divided longitudinally and transversely, and the separated portions bave either again united or become developed into separate animals. On two occasions I have met with results similar to those described by the Abbé Dicquemare, having divided transversely several specimens of the common Anemone (A. Mesembryanthemum) in such a manner that any thing taken in at the month passes out at the truncated surface below; but the cut surface closed in a few days so as to retain the food and in six weeks a new mouth and tentacula were formed, presenting the curious spectacle of an animal taking food at both extremities. If in taking the animal from its situation it be very much mutilated, it soon regains its former state, and if a portion be separated, it will frequently be developed into another polype. It has been said that if the base be torn the animal dies; an observation I am unable to confirm and have gond reason to doubt. If any portion of an actinia be injured or destroyed, the animal possesses a power of replacing it. This power of reproducing lost parts, however, is not confined to Zoophytes, but is found in the re-formation of the rays of star fishes, of the claws of crabs, and extends even to the vertebratæ as is seen in the Batrachian reptiles.

The manner in which the water is taken in and expelled in the Actiniz is not yet settled. Professor Jones says it is taken in through the tentacula, while Professor Sharpey says he has repeatedly noticed the water entering by the mouth, and I have on many occasions seen the same thing; perhaps some also enters by the small openings distributed over the surface, and through which the white threads are sometimes expelled. It sometimes escapes by the mouth and frequently through the tentacula; if the animal be pressed, it will be found to escape only through a few of the tentacula, but if the animal be allowed to eject it itself, nearly all are pervious; from which it would appear that great foreign pressure prevents a relaxation of the muscles guaruing the orifices. 
As we have had occasion to mention the great resources of nature in effecting her objects, so we may now notice the wonderful economy she observes in making those resources subservient to different purposes. The water not only serves as a fulcrum for muscular action, but for the purposes of respiration and the perfection of the ova; and to each of these functions it is equally indispensable. The function of primary inportance in all animals appears to be the respiratory; if this be deranged in these creatures we soon see the strange condition into which they are thrown, and the contrast it forms with the healthy state, in which every function beautifully depends on the others. If an $A_{c-}$ tinia be placed in deteriorated water, it endeavours to make up in the quantity what it loses in the quality of the water. It imbibes so mucb as to distend the body to an enormous extent; so much as to make it resemble an inflated bladder, rather than the animal it is. The pressure of the water behind forces the stomach out of the mouth, which together with the white threads, hangs in transparent lobes over the sides of the animal. As the respiration appears to be carried on chiefly by vibratory cilia, and these filaments and the stomach are clothed with them. their exposure greatly assists the process by enlarging the surface and exposing it to more water. The ora also suffer a considerable check in their developement, hence many that have been kept in unfavourable positions on the shores have never increased, and having become transparent, it could be seen that the ova were very imperfectly developed in any and in some not at all; and there they are and bave been for two years and half, the same in number, though different in appearance. Those always thrive best that are most exposed to the violence of the sea. When thus distended their muscular energy is always diminished and sometimes nearly destroyed; a fresh supply of water, however, soon redeems them to their healthy state.

The mancer in which the developement and exclnsion of the ora takes place is still an undecided question. No one, however who has watched these creatures, can have failed to observe the fully formed animals expelled alive through the stomach; nor can any one who bas been in the habit of dissecting them have failed to notice the young animals in the interseptal spaces, exterior both to the ovaries and the threads, supposed by some to be oviducts. Mr. Teale's explanation seens to be the best, as it fully accounts for all the positions in which the young have been found. He thinks that when the ora are sufficiently matured, they burst their membranous envelope and "become lodged in the interseptal spaces;" fron these points they can travel into the 
tentacula, where they are frequently found, or into the sto. mach. On many occasions, when forcibly pressing the $\boldsymbol{A}$. Mesembryanthemum, several of the young have been forced through the tentacula. The ova which are yellowish, are clothed with cilia, and become frequentiy developed into the polype internally. It would be out of place here, and tend to increase the size of this work too much, to enter into this and several other particulars more minutely. As they would be of interest only to the Anatomist and Physiologist they are passed lightly over. The first and most common mode of reproduction is by ova, the second by budding, as is observed only in the Zoanthus. In this genus the trailing fleshy band which connects the different polypes becomes enlarged at intervals into papillary eminences, and afterwards becomes developed into polypes.

Another mode of reproduction sometimes takes place by division. Having kept some specimens of $A$. dianthus in confinement, it was found that they would occasionally divide at the base, and the division would proceed upwards to the oral disc. In this state they look just like what the Alıbè Dicquemare describes as the union of two individuals from contact. Possibly such an union may take place, as they are so gregarious as to be actually in contact, and double mostrosities occur at birth; but I have not seen it.

The Zoanthus Couchii is the only compound species of our shores. It may be characterized as a number of small actinia united at their bases by a trailing fleshy band. It is a very limited genus and till the discovery of a species on our shores a short time since, had no representative in Europe.

The next genus Lucernaria is a remarkably pretty one, and from its activity and transparency, a very interesting one. In form, it very closely resembles the old fashioned conoidal wine glasses; having a round disc-like base, a round columnar stalk, which terminates superiorly in a free campanulate expansion; around the margin of which are eight separate tufts of tentacula. I never could find that Lamourous' assertion, that they perceived their prey at a distance and pursued it, was correct, though I bave watehed many scores in their natural situations for that purpose. They only seem conscious of the presence of food when it impinges on the tentacula. The ova are developed about A pril, May, and June, either in loops from tuft to tuft, or in lines from the tentacula to the base, and are frequently there united in pairs. They are subject to a great many variations of colour but are generally brownish, brownish-green or biowuish-red. Their tood consists chiefly of small crustaceans.

The only calcareous species we have, is tho comparatirely insignilicaut one, the Caryophyllia Smithii. It is common at 
ail depths to a little beyond low-water mark. The animal, when expanded, resembles in form the naked Actinix; when contracted it retires from sight into the calcareous cup. It is to be found of all sizes from a mere speck to an inch in height. In a very young state it is sometimes found parasitical on the Alcyonium digitatum, on shells, and the stalks of sea weed; but as these substances are very perishable in their nature, and offer no solid foundation on which to stand, large specimens are never found on them; on rocks and stones, however, they are frequently large and in great profusion. In the youngest state the animal is naked, and measures about the fifteenth of an inch in diameter and about the thirty-second of an inch in height. In the earliest state in which I have seen the calcareous polypidom, there were four small rays, which were free or unconnected down to the base; in others I have noticed six primary rays, but in every case they were unconnected with each other. Other rays soon make their appearance between those first formed; They are mere calcareous specks at first but afterwards increase in size. The first union of the rays is observed as a small calcareous rim at the base of the polype, which afterwards increases both in height and diameter with the age of the animal.

In taking a review of the polypes of this order, we find that though there is a considerable resemblance in their general anatomy to that of the Asteroid polypes; yet there is also a considerable advance in the complication and elaboration of their various parts. In both there is the radiate form of tentacula, the central membranous stomach, the intervening space between the stomach and sides of the polypes, the dividing the space by longitudinal septa, and one opening serving both for the reception of food and ejection of the undigested remains. In this there are permanent organs set aside for the developernent of ova, forning well defined ovaries; the structure of the septa and the sides of the animal are of a muscular kind; and here also are said to be the first traces of a nervous system; all of which show a considerable advancement on the two preceding orders; and their habits and intelligence also exhibit a correspondent elevation.

The comparative smallness and simpleness of the only calcareous species of our shores, has not allowed many observations to be made on the vitality or non-vitality of the polypidom. But few as they have been they greatly affect the question. In young specimens the polypidoms are very small and increase in size with the age of the polype; so that the base of an old specimen is five, six and sometimes eight or nine times larger than young ones. From 
which we may conclude that a continual absorption and deposition goes on in this apparently inorganic mass. That a vital action does take place in this calcareous base is confirmed by the collateral evidence of what takes place in the larger species of other climates. Mr. Stutchbury in his valuable paper on the growth of young corals of the genus Fungia, proves that the young are thrown off from the parents, and that the cicatrices are afterwards filled up with a fresh deposit of calcareous matter.* De la Beche also, in his Menus of Geology quotes Mr. Lloyd as detaching some "polypifers" from their place of growth on the Isthmus of Panama, leaving them behind in pools for a day or two, and as finding them afterwards fixed to the spot by a fresh secretion of calcareous matter. These and other observations scattered through numerous papers in the transactions of learned societies, scarcely leave a doubt on the subject.

Though these beings are of so low a grade in the scale of life; yet they have exercised in ages past, and still cuntinue to exert a great influence in the history and economy of the earth's surface. Though so insignificant and apparently, even contemptible in themselves; yet by their combined energy and imperishable masonry they have raised

A new creation in the secret deep.

Omnipotence wrought in them, with them, by them;

Hence what Omnipotence alone could do

Worms did :

and islands of importance and great beauty are every where scattered through the South Seas; coral reefs are still forming, and extending even to the waters edge, waiting for some upheaving to convert the Ocean into dry land. The Geologist tells us that in the earliest ages they had a more extended range than at the present time. He considers them as indices to the revolutions which the earth has undergone since the Creation. Whether these speculations be true or false, yet we must all confess that these worms have always held a situation of vast Geological importance:- a situation, the more we contemplate, the more miraculous it seems.

\section{MADREPHYLLAA.}

Body cased with a solid calcareous cupped polypidom, lamellated internally.

\section{CARYOPHYLLIA. Lamarck.}

Generic Character: Aninal like the Actinia; polypidom permanently fixed, simple, cylindrical or conoid, striated externally in a longitudinal direction, the top hollowed into a lamellated stellular cap.

* Lin. Trans., vol. 16.

+ Geol. Manual, p. 151, 1832. 
C. SMITHit. Polypidom cylindrical, lamellæ entire, arched, finely crenate, from three to five smaller ones between the larger, centre tubercular. Pl. 12, fig, 3.

Madrepora cyathus, Ellis and Solander's Zooph., p. 150, 1ab. 28, fig. \%. Caryophyllia cyathus, Fleming's Brit. An., p. 508. Caryophyllia sessilis, Bellamy's South Deron Nat. Hist., p. 330, tab. 18. C. Smithii, Harvey in Mag. Nat. Hist., vol. 1, new series, p. 474, fig. 55, (the figure of the animal inaccurate.) Johnston's Brit. Zooph., p. 207, fig. 30, p. 206.

Hab. On stones from deep water, abundant. Polperro, Goran, Mevagissey, Veryan.

There is scarcely a stone drawn from deep water, but has several specimens of this species attached to it, and in many cases so many as sixty, or even more.

The height of this Zoophyte varies from one-eighth of an inch to an inch; it is calcareous, cylindrical or conical, lon. gitudinally striated externally, and firmly united to the rock. Superiorly it is cupped or concave, and lamellated. The lamellæ may be divided into three kinds; first, the primary or larger ones, which rise above the rest and extend from the circumference two-thirds towards the centre, and vary in number from twelve to twenty, and Dr. Fleming says to forty; this number does not depend on the size of the specimen. Between these primary ones are three smaller ones, the centre one of which is the largest, and extends from the circumference halfway towards the centre, where it apparently ends, but soon after rises into another gill, forming an inner series, lying between the primary ones and the tuberculated centre. The external longitudinal striæ, are formed by the attachments of the gills inside.

The animal is an Actinia, and when expanded is delicately beautiful. In expanding, the mouth is first elevated, and is about one and a half lines in length, surrounded by a light yellow or brown rim, marked transversely by rugæ, as if it was formed of lamellæ, but when fully expanded it becomes smooth and polished. Beyond this labial rim are two or more series of tentacula, similar in form to the horns of a snail, light brown at their bases or origins, with white rounded ball like extremities, made more conspicuous by each having a vermillion circumference. The colour of the animal however, is liable to great variation; it is sometimes red, yellow, orange, or brown, but the white rounded extremity of the tentacula is constant.

I have obtained specimens on this coast from the thirtysecond of an inch to one inch in height; from having only four primary rays, up to twenty. 
The shape of this species is subject to variation, being either conical or cylindrical. The cylindrical, the C. Sessilis of Bellamy, is low and may be said to be blended with the rock on which it stands: while the conical ones, which have a foot-stalk, when arrived at a certain size, may frequently be removed by the fingers. This I considered to be the Turbinolia Borealis of Dr. Fleming, which is described as being "widely conical and slightly bent," and said to become detached by age, but Dr. Johnston tells me it is the C. Smithii of his work.

ZOANTHUS. Cuvier.

Generic Character: Polype mass compound; polypes distant, united at their bases by a trailing fleshy band, or broad fleshy base. Animal an Actinia.

ZOANTHUS COUCHII. Johnston. Polype-mass compound; polypes distant, when contracted hemispherical, when expanded, pedunculated, united at their bases by an encrusting fleshy band; tentacula in several circles. Pl. xv., fig. 2 .

Hab. On flat slates and rocks in deep water from one to ten leagues from the shore, throughout the Cornish part of the British Channel. Common.

This, in being compound, differs from all other European species of the order, and approaches very closely in form to the Actinia sociata of Ellis. It is a very small species, and composed of a number of Actiniz united together at their bases by a thin, encrusting fleshy band. It is of a light sandy or opaque red colour, and its surface is minutely glandular. In its contracted state it is sub-conoidal; resembling both in shape and size a split pea. When living, except that it is glandular, its surface is plain, but when preserved it becomes corrugated. When semi-expanded, which is its favourite state, it elevates itself to about wwice its former height and beconics contracted about its middle into an hour glass form. The upper portion is lighter than the lower, and the superior or oral surface is marked by a central depression or mouth, and from it radiate to the circumference, numerous rows of whitish glandular looking bodies, which are the tentacula in a contracted state. When the creature is fully expanded, the tentacula become distended and elongated to about the length of the transverse diameter of the body; and they are generally darker at their extremities than towards the base. Like all the Actiniæ, the present species possesses a power of considerably altering its shape; most frequently it is in the shape of an hour glass, at others the oral surface is contracted to a mere point, and then occasionally, is again enlarged to nearly twice the size of any other part; sometimes the mouth is depressed, and at others is clevated into an 
obtuse cone. This species in addition to being rnoted is one of the most inactive of its order; for whether in a state of contraction or expansion it will remain so for many days or even a week without apparent change. If it should be in an expanded state, a touch will make it contract, and it will, most commonly remain so for several days. Its most favourite state, is the semi-expanded in which it will sometimes remain from a week to a fortnight without change.

The trailing connecting band is flat, thin, narrow and of the same texture as the polype and glanilular. It frequently gets enlarged into small papillary eminences, which as they become enlarged, become developed into polypes.

This species and the Actinia sociata of Ellis are very closely allied to each other; this, however, is shorter, smaller and not so much pedunculated as Ellis figures his to be, and the fleshy band also appears to be thinner and wider.

Having communicated specimens to Dr. G. Johnston, he is of opinion that it is distinct from Ellis' species, and has done me the honour to give it the name quoted above.

\section{ACTINIID AE.}

Body naked, fleshy, contractile, locomotive.

\section{ACTINIA, Linnæus.}

Generic Characler: Body conoid or cylindrical, adhering by a broad base : the space between the month and the rim of the upper disc, occupied by one or more series of conical undivided tubular tentacula, which are entirely retractile.

\section{SEA-FIG MARYGOLD; SEA-ANEMONE; COWS.} A. Mesembryanthemum. Body conical, smooth; tentacula in several rows; around the oral disc a row of azure blue tubercles. Pl.iv., fig. 1.

Hydra Mesembryanthemum, Stewart's Elem., vol. 2, p. 451. Actinia Equina, Fleming's Brit. An., p. 497. A Hemispherica, Pennant's Brit. 'Zoology, vol. 4, p. 50. Templeton in Mag. Nat. Hist., vol. 9, p. 303. A. Rufa, Stewart's Elem., vol. 1, p. 393. Actinia Mesembryanthemum, Johnston in Mag. Nat. Hist., vol. 8, p. 81. fig. 12; Brit. Zooph., p. 211, fig. 31, p. 210. Ellis and Solander's 'Zooph,, p. 4. 'Turton's Lin., vol. 4, p. 104. Sea-Anemone, Roget's Brilgewater Treatise, vol. 1, p. 198, figs. 86,87 .

Hab. On rocks and stones between the tide marks; abundant all along the coast.

This species is so common on all parts of our coast, that it is hardly necessary particularly to describe it. It is generally of a reddish brown, liver, or olive green colour, and lives in a very scattered manner in pools and on the 
shelving sides of rocks between tide marks, where it is frequently left dry by the ebbing tide. In a contracted state it is hemispherical or conoidal ; in its expanded more or less columnar, with its upper extremity surrounded with several series of tentacula, and a free plaited margin which folds in and covers the tentacula when the animal is contracted. It varies in size to one inch or one inch and half in diameter at its base and to the same in height. The surface of the body is smooth, but is frequently drawn into longitudinal and circular folds at the will of the animal. The colour is liable to many variations of brown, green, red and sonetimes a mixture of the whole in longitudinal stripes. The tentacula are in several series, small and with the oral disc always of a lighter colour than the rest of the body; between the outer row of tentacula and the free plaited edge of the disc is a circle of azure blue tubercles, which are most apparent when the animal is semi-expanded. Though these tubercles are described as being blue, yet I have seen many red, and in one locality they are all white, the whole animal in the same spot is very frequently of a transparent whitish pink colour, and sometimes of a pure white. This spot is rather exposed to the sea, but sheltered by a ledge of rocks, the bottom is sandy, and the place is very frequently nearly filled with decomposing sea weed. The verge of the base is always of lighter or different colour from the body and is very frequently formed by a blue band.

Gærtner was of opinion that this species changed its colour with the seasons, being red in summer and brown or green in autumn, this however appears to be without foundation; the red, hrown and green varieties occur mingled together at all seasons; there is, perhaps, a littlo variation in the lightness of the tint during summer, but each retains its own colour throughout the year. In some situations, such as the upright face of a stone in a sandy or muddy soil, the animal becomes so flaccid and so different in form and colour, as scarcely to be recognised; but they always possess the rini of tubercles, and by this they niay be known. It is a very cleanly species, and always prefers for its place of fixture the sloping surface of a rock, where it can be abundantly supplied with good water ; if this cannot be procured, it suffers by the change.

ACTINIA VIDUATA. Body conoid, longitudinally striped with light brown or yellow and white; tentacula marked with circles of the same.

Actinia Viduata, Johnston in Mag. Nat. Hist., vol. 8, p. 82, fig. 13; Brit. Zooph., p. 211, fig. 29, p. 205.

Ilab. Fron deep water on the Pinna ingeus; and in santiy ground near low water mark. Polperro, Whitsand bay, Coomb, de. 
Dr. Johnston considers this a variety of the preceding species, but where we have a pernanent difference in the appearance of an animal, connected with a difference of habit, there is I think sufficient grounds for making it a distinct species. Dr. Johnston says, "this variety attaches itself to shelving rocks, where it is concealed and covered over by a layer of sand, protruding the tentacula through a small aperture at the surface opposite the mouth; on the recess of the tide nothing of the animal can be seen, and its presence or locality is only to be guessed at by the holes in the sand." This forms a good characteristic habit, but the opposite of the last kind, which prefers a clean rock.

SEA-DAISY. A. Bellis. Body lengthened, the lower part narrow and smooth, the upper enlarged and glandularly warty; oral disc expanded, lobed; tentacula, in several rows, variegated.

Actinia Bellis, Ellis and Solander's Zoopl., p. 2, no. 2. Turton's Lin., vol. 4, p.103. Hydra Bellis, Stewart's Elem., vol. 2, p. 451. Actinia Peduculata, Pennant's Brit. Zoology, vol. 4, p. 49. Fleming's Brit. An., p. 498. Templeton in Mag. Nat. Hist., vol. 9, p. 303. A. Bellis, Johnston's Brit. Zooph., p. 212.

Hab. In sheltered situations and covered pools, under Chapel Hill, Polperro, Talland sand bay, Lantivet bay, and Whitsand bay; pools about Mount's bay, in companies of four or five.

The base of this species is narrow and smooth, above it is expanded and tubercular or warted, to which, fragments of shells and stones adbere, so as to blend the appearance of animal with the surrounding ground. When expanded, the variegated tentacula, which are arranged in several rows and vary in length, present a very elegant and beautiful appearance. Its general colour is carnation, changing into purple, violet, and brown, sometimes interspersed with sap-green spots. The colour is howerer liable to variations in the depth and lightness of the tints, and the tubercles are sometimes confined to the upper portion of the body and at oithers extend to the foot; so that there appears to be no specilic difference between this and the next.

STUDDED SEA-FLOWER. A. Gemmacea. Body conical, variously coloured, covered with warty protuberances, which are sometimes very obscure; tentacula in three or four rows, inner row longest, rariegated with red, brown, and white, transparent near the base.

Actinia Gemmacea, Ellis and Solander's 'Zoopl., p. 3, no. 3. Turton's Lin., rol. 4, p. 104. Johnston's Brit. 'Zooph., p. 213 , 
- pl. 2\%. Actinia verrucosa, Pennant's Brit. Zool., vol. 4, p. 49. A. monile, (young) Templeton in Mag. Nat. Hist., vol. 9, p. 303. Hydra geınmacea, Stewart's Flem., vol.2, p. 451. A. senilis, Flem. Brit. An., p. 498.

There are four varieties of this species, which it will bc necessary to notice :

First. Body warty; the warts large in vertical rows. Hydra gemmacea, Stew. Elem., vol, 2, p. 451. Actinia gemmacea, Ellis and Solander's Zooph., p. 3. Turton's Lin., vol. 4, p. 104. Actinia verrucosa, Pennant's Brit. Zool., vol. 4 , p. 49.

Second. Body warty ; warts equal, distinct, and scattered irregularly. Templeton in Mag. Nat. Hist., vol. 9, p. 303.

Third. Body warty; warts small, obscure, and distant. Actinia equina, Pennant's Brit. Zool., vol. 4, p. -

Fourth. Body smooth, clouded with scarlet; tentacula with red and white. Actinia crassicomis, Turton's Lin., vol. 4, p. 100. Stewart's Elem., vol. 1, p. 393. A. truncata, Turton's Lin., vol. 4, p. 101.

Hab. In pools on stones, near low water mark; West Combe, Lansallos, Chapel Hill, Whitsand bay, Goran, \&c. From deep water, on shells and stones. Common; and is very commonly left dry by the receding tide; these are very tubercular and covered with fragments of stones.

This is amongst the largest and most gaudy of the British Actiniide, and from the great difference in the nature of the localities in which it is found, it is liable to a great many variations in colour and appearance. It is most commonly about two inches, or two inches and half in diameter, but one specimen, when fully expanded, measured six inches and half across the oral disc; this was procured from deep water, but it is most commonly smaller. It is generally of a red colour, but is not unfrequently striped with yellow, blue, and sap green; the surface is most commonly studded with tubercles, which in different individuals are differently arranged. In some the tubercles are large and arranged in longitudinal bead-like rows; these are found near the shores and in the neighbourhood of sandy soils. In others, the tubercles are smaller and without any regular distribution, and in some they may be said almost to have disappeared. These tubercles are always of a lighter colour than the surrounding parts, and have very frequently adhering to them, fragments of shells and stones, by which the animal conceals itself from view. In a contracted state it is hemispherical or conoidal, with a broad base and a low rounded apex; in an expanded state it is shortly columnar, 
and its upper surface is surrounded by several rows of variegated tentacula. The mouth is central, and surromnded by a thick lip of a reddish colour. This is marked at two opposite points with a radiating line of a light colour and frequently of a rose tint terminating in white, but varying in different, individuals. Beyond this lip is a narrow circle of white, more or less distinctly marked; beyond this is a darker surface, semi-transparent and surrounded by several rows of tentacula. The base of each tentaculum is embraced by two red, and the inner row also by two white lines, which converge on either side and cross the oral disc on the one hand, and pass between the the bases of the tentacula on the other. Each circle of tentacula is regularly marked with bars of carnation, lake, lrown, yellow, and white, in such a manner that a series of coloured circles is formed around the mouth; so that when the animal is fully expanded it presents a scene of such remarkable brilliancy and beauty as to rival even the flowers; but it is liable to so many variations in the arrangement and depth of the tints that a description will serve only for a few individuals. The resemblance to a flower is very great, and a stranger might be excused for mistaking it. On one occasion while watching a specimen that was covered merely by a rim of water, a bee, wandering near, darted through the water to the mouth of the animal, evidently mistaking the creature for a flower, and though it struggled a great deal to get free, was retained till it was drowned and was then swallowed.

When an individual of this species has been kept in confinement for some time it gets flaccid and semi-transparent, the lips become everted and several transparent striated lobes become evolved, and sometimes to such an extent as to hang over the sides. Though this at first is done apparently at the will of the animal and can be withdrawn at pleasure, yet it appears to be in some measure a sign of disease, for the animal finally gets so flaccid and distended as to bo unable to regain its natural size or to withdraw the ejected lobes. In a natural state in good situations I have never seen them evolve the inflated lobes, but in muddy soils it is not uncommonly done; there they are flaccid and unhealthy, as they are in confinement. Dicquemare prefers this to any other kind for the table, and recommends them to be boiled in salt water, "when they will acquire a firm and palatable consistence and may then be eaten with any kind of sauce;" but to an English palate they would olfer no very tempting dish. 
SEA-CARNATION. A. Dianthus. Body cylindrical, snooth, oral disc expanded, lobed, with numerous irregular tentacula; outer row shortest and forming a fringe. Hydra dianthus, Stewart's Elem., vol. 2, p. 451. Actinia diantlus, Ellis and Solander's Zooph., p. 7, no.9. Turton's Lin., vol. 4, p. 104. Fleming's Brit. An., p. 498. Stewart's Elem., vol. 1, p. 394. Johnston's Brit. Zooph., p. 216, pl. xxviii. Actinia pentapetala, Pennant's Brit. Zool., vol. 4, p. 104, A. plumosa, Turton's Lin., vol. 4, p. 100. Stewart's Elem., vol. 1, p. 394.

Hab. Common in pools, within low water mark; Polperro, Talland sand bay, East Coombe, Gorran, Fowey.

This common species is to be found in the crevices of rocks in pools between tide marks. It is gregarious, and the large and small, old and young indiscriminately mix together. In a contracted state it is sub-conoidal, the apex of the cone being rounded and depressed. The surface is smooth, or but faintly striated in a longitudinal manner. The most prevailing colour is a chesnut brown; but it is sometimes of a pale ash, whitish or yellow tint. When brown it bears a very great resemblance to the $\boldsymbol{A}$. Mesem. bryanthemum in a contracted state. When expanded the body is columnar, but is liable to variations from unequal contractions of the longitudinal and circular muscular fibres. The circumferance of the oral surface is generally contracted into from three to eleven festoons. The tentacula are very numerous and short; the longest are the most central, and the shortest the most external, forming a mere fringe. The upper surface being thus lobed and fringed with short tentacula generally variegated with bars of yellow, brown, light blue, green, \&c., which are very beautifully blended, has a very soft and rich appearance; sometimes however the tentacula are of a pale ash colour with their bases brown. The intervening space between the mouth and tentacula is plain and smooth; and it is either of a brown colour or variegated with radiating bands of brown and cream colour. The mouth is central and oval, and the lips are generally of a bright vermilion colour, but this varies in different localities. When expanded this is a very beautiful species. The studded sea flower, certainly exceeds it in the brilliancy and contrasts of its colouring, but for beauty, richness, and softness in its tints, it is without a rival.

Though decidedly gregarious, it is not so much so as the next. It prefers the crevices of the open pool, rather than the narrow deep and hidden ones as is the habit of the next species. 
ACTINIA TEMPLETONII. Body columnar, tubercular; disc festooned; tentacula numerous and short.

Actinia dianthus, Temp!eton in Mag. Nat. Hist., vol. 9, p. 304.

Hab. In narrow deep crevices between tide marks, common. Whitsand bay, Looe, Talland sand, Polperro, Lantivet, and Mevagissey bays. Fowey.

This, though not an abundant, is a common species, found in pools the whole length of our South coast. It is highly gregarious, the animals living in close contact with each other. It prefers those crevices which are narrow and deep, in pools containing fragments of stones and Corallina officinalis; but is not unfrequently to be found in spots of an opposite character. In to these recesses it readily withdraws from danger or alarm. When thus contracted, it is entirely out of sight, and almost out of reach. Thus situated, it is necessary to break down the surrounding rock to procure a specimen. It will occasionally leave these retreats and wander by an almost imperceptible gliding motion of the foot disc over the whole pool.

In a contracted state it is hemispherical, expanded, columnar, varying in length according to the depth of its retreat. Externally it is coriaceous and irregularly glandular; superiorly it is of a neutral tint inclining to pink; inferiorly, of a yellowish flesh colour, and most commonly smooth. The oral margin is festooned, and the surface is varigated like $A$. dianthus.

This and A. dianthus have hitherto been considered as forming one species; but the surface of one is coriaceous and tubercular, and of the other plain and smooth. This and their difference of habit appear to be sufficient grounds for a specific distinction. Both have been found living in one pool, with all these differences; therefore locality alone cannot be said to be the cause of the variations. This is the same as the one mentioned by the late Mr. Templeton of Ireland and supposed by Dr. G. Johnston to be distinct from A. dianthus.

As there is little doubt of its being distinct, I propose to call it Templetonii in honor of that deceased naturalist.

ACTINIA PARASITICA. (R. C.) Body cylindrical; skin coriaceous, sprinkled with minute warts; tentacula short, in six or seven series, varied. Pl. xv., fig. 1, 2.

The body, when the animal is expanded, is columnar, with a hard coriaceous skin sprinkled with minute warts and alternately striped with yellow and brown. The tentacula are about one-third the diameter of the oral disc; rather slender; mouth generally elevated into a cone. This may 
probably be considered a variety of the Actinia gemmacea, as that kind is liable to so many variations, but it had not the appearance of belonging to that species. The favourite site for them is on the claw of the Corwich crab, (M. verrucosa) and on the Pinna ingens.

ANTHE A. Johnston.

Generic Character: Body cylindraceous, adhering by a broad base; tentacula disposed in circles round the mouth, elongated, tapered, and incapable of being retracted within the body. Johnston.

SEA.TORCH THISTLE. A. Cereus. Body smooth, cylindrical, longitudinally furrowed, ending superiorly in a waved line; tentacula long and generally tipped with red. Pl. xiv., fig. 2.

Actinia cereus, Ellis and Solander's Zooph., p. 2, no. 1. Turton's Lin., vol. 4, p. 103. Actinia sulcata, Stewart's Elem., vol. 1, p. 394. Fleming's Brit. An., p. 498. Pennant's Brit. Zool., vol. 4, p. Hydra cereus, Stewart's Elem., vol. 2, p. 451. Anthea cereus, Johnston's Brit. Zooph., p. 221.

Hlab. In the crevices of the rocks; Polperro, Talland sand, Looe, Fowey; comnion.

This species is very common on all that part of the south coast that has been examined, as much, if not more so than the Sea Anemone, A. Mesembryanthemum, but as it is gregarious and confined to pools and crevices of rocks which always remain covered with the sea, and of a light colour, it is not so readily observed as that species which lies indiscriminately scattered over the rocks between tide marks. The pools they prefer are those which have a southern aspect and which are visited by the sea at every tide. Sometimes they occur only in small companies, and at others singly, aceording to the nature of the spot, but I have frequently found them covering a surface of three feet in diameter. The animals are generally in close approximation with each other, and most commonly in contact. They are liable to so many changes of form that a minute description of them would be both tedious and useless. In a contracted state, they are generally columnar and of equal diameter throughout, and the tentacula diminished both in size and length; sometimes they are hemispherical, with the tentacula pressed together and protruding from a central orifice; at others the body is drawn towards the base and flat, while the oral surface is exposed or covered only by the contracted tentacula. The surface of the body is smooth, but longitudinally striated; the furrows run from the base to the margin of the oral disc, where they terminate in a waved or festooned 
border or margin. Each space between the furrow's, is frequently again furrowed by two or three finer ones; but these are not always apparent, especially when the animal is much distended. When the polype is fully expanded, the oral surface is frequently enlarged from balf-an-inch to one inch and half, and the furrows of the sides appear as if they terminated superiorly in tubercular looking bodies. The shape varies as in the contracted state, from the columnar to the hemispherical and hourglass contracted form. The oral surface is generally of a darker brown than the other parts, and nearly always marked with one, frequently with two, and sometimes with many w!ite radiating lines, which terminate at the base of the tentacula. The mouth is central, slightly elerated, irregular in shape, and marked with two furrows internally which run down into the stomach. The tentacula are long and stout, and vary in number with the age of the individual; Gærtner says they amount occasionally to 200 , and I have counted 150 ; they are about twice the length of the body when fully expanded, and are incapable of being withdrawn as is the case with the Actiniæ. They are of very unequal length and size, and frequently get contracted in various parts as if diseased; this is most probably the case, since the upper portion is frequently sloughed off, and thus they become truncated. I have in four instances found the tentacula on ove side entirely absent, or so short as to be little more than mere tubercles and others springing up in their places. Almost every specimen examined, shows this growth and decay of the tentacula in a greater or less degree, the smaller ones springing up between the larger and perfect ones in every degree of length. Beside this, the tentacula are liable to mal-formations, some give off one or more lateral spronts, and others I have seen dichotomously branched; this last however is very rare.

There are two varieties of this species, equally common, which are always intermingled with each other at all seasons. One is of a light fawn colour both in the body and tentacula, but the oral surface is rather of a deeper colour than the other parts; the other is of a pea-green and remarkable for the great delicacy of its tints; the tentacula are always lighter than in the brown variety, and they have a white line running up on one side. In the green kind the tentacula are always of a rose colour at their extremities, which is in the spring and summer of a deeper tint, and extends sometimes over two thirds the whole length. Grortner has seen it extend and colour the whole tentacula of a red-mahogany colour. The brown variety is frequently without it.

This appears to be a more active kind than any of the Actinix; its tentacula are constantly expanded and in con- 


\section{3}

tinued, tlough gentle action. It moves freely about from place to place by a gliding motion of its base; or by turninir on its oral surface, can move far more rapidly by means of its tentacula.

\section{LUCERNARIA.}

Generic Character: Body somewhat campanulate, fixed when at rest by a narrow disc or stalk; mouth quacirangular, in the centre of a reversed umbrella-like expansion; tentacula disposed in widely separate tufts on the margin.

L. AURICULA. Borly funnel-shaped, with eight equidistant tufts of tentacula round the margin; between each tuft a marginal tubercle. Pl. xvi., figs. 1, 2, 3.

Lucernaria auricula, Turton's Lin., vol. 4, p. 121. Fleming's Brit. An., p. 499. Johnston in Mag. Nat. Hist., vol. 5, p. 44 ; Brit. Zooph., p. 229, fig. 3j, p.230, fig. 36, p. 193, fig. 28. Templeton in Mag. Nat. Hist., vol. 9, p. 304.

Hab. On fuci, at Talland sand bay, Chapel pits, Polperro. Abundant about June, July, and August.

This species I have found abundant in some years, while in others, I have hardly been able to procure a single specimen. Though I have supposed it the L. auricula of the authors quoted above, yet it differs in some important particulars. The form of the body very much resembles the conoidal, or old form of wine glasses; the upper and free margin is surrounded by eight equi-distant tufts of tentacula. From each of these tufts of suckers a thick chain of brown glandular looking bodies proceeds downwards, for about two-thirds the length of the body, where they unite in pairs, and then proceed as a very delicate thread to the base. The foot-stalk is small and tubular, resembling the stalk of a wine glass, and under certain lights appears to be annular, or to have a spiral thread running its whole length. The termination of this foot-stalk is in a flat cup-like disc, by which it adheres to the fucus on which it stands. Between each pair of tufts of tentacula is a marginal gland. The mouth is central, elevated, and somewhat quadrangular. At the four angular projections of the lip are four bodies attached externally, rounded superiorly, and pointed inferiorly.

The colour is generally of a reddish brown, but is sometimes of a liver brown, green, or yellowish. They fix themselves to the fuci by their sucker-like discs, in nearly an erect position; never, however, hanging down or standing perfectly erect.

Their mode of progression differs under different circumstances. If intending to move to any great distauce, they do so by loosening their attachments, and then by various and active contortions, waft themselves away till they meet with 


\section{1}

an obstruction; there they rest, and if the situation suits, they fix themselves, if not they move on in the same manner to some other spot. If the change be only for a short distance, as from one part of the leaf to another, they bend their campanulate rims and bring the tentacula in contact with the fucus, and by them adhere to it; the foot-stalk is then loosened, thrown forward, and twirled ahout, till it meets with a place to suit it; it is then fixed and the tentacula are loosened, and in this way they move from one spot to another. They sometimes also move like the Actiniæ by a gliding motion of the stalk.

In taking their prey they remain fixed, with their tentacula expanded, and if any minute substance comes in contact with any of the tufts, that tuft contracts, and is turned to the mouth, while the others remain expanded watching for prey.

The differences between this and Dr. Johnston's specimens are as follows. The brown glandular bodies of the free rim proceed from the tentacula in this, while in Dr. J.'s there is a slight distance between them; this may arise from the advanced state of the ova in my specimens. In this the chains of glands from the tentacula unite in pairs at three-fourth's of the length of the body; in the others they proceed singly to the base. In this, the footstalk is distinctly separate from the campanulate rim, in Dr. Johnston's it is said to be sessile, and there is no distinction between the base and the other part. The peduncle, or foot, terminates in a flat, suckerlike expansion while in the other, buth in the figures and description, it is absent. These characters have not been observed in a single specimen only, but in scores, and may therefore be considered permanent variations or characters.

SUB CLASS II.

\section{MOLLUSCAN ZOOPHYTES.}

Body non-contractile, and non-symmetrical; mouth and anus separate; gemmiparous and oviparous.

ORDER IV.

$A S C I D I O I D A$.

In the Ascidian Zoophytes, the Ciliobrachiata of Farre, we shall observe a very great advance in the complication of the anatomy of the polype. Though possessing most of the external characters of the Hydra, and in its oeconomy and fabrication of its habitations also similar; yet we shall 
find that the external characters of the Radiata are engrafted on a type of tunicated Mollusca: characters, though distinct from each, which yet soften away into both. Some of the polypes of this order have been arranged by most authors among the Hydroida, in consequence of their polypidoms resembling those of the Sertulariadx. By the examination of their polypes, however, they are now transfered to the Molluscan zoophytes; and this grouping seens far from being unnatural, even when their external forms are considered. Whatever alteration may be made in the future arrangement of these creatures, when they shall have been more thoroughly studied, yet the making the polype the foundation on which to rest, is the only true one to guide the systematist. The order is characterized as "Polypes aggregate, the mouth encircled with filiform, ciliated, retractile tentacula; stomach distinct, with a curved intestine terminating in an anus near the mouth; ova internal. Polypidoms very variable; either horny, fistular, and confervoid, or membranous or fibro-gelatinous; formed of cells connected and arranged in a determinate, and usually quincuncial manner."

As the polype, therefore, forms the foundation of the arrangement, it will be necessary to describe it, though without entering into minute detail. In its expanded state it stands prominently from the cell; it is columnar and transparent, so that the internal structure can be seen. Between the surface of the polype and the internal organs, there is an intervening space, similar to what has been noticed in the Asteroid zoophytes. This space is said to be occupied by a clear fluid; and here also are the muscles, by which the polype effects its rarious and rapid motions. The upper portion of the column is surrounded with numerous long slender tentacula. In the foregoing orders it has been found that the chief uses of the tentacula were for the capture of prey; here their functions have undergone a complete revolution, for to them belongs the function of respiration, and in a secondary degree only that of nutrition. If an expanded polype be examined with a microscope, it will be found to resemble a minute and delicate flower endowed with sensation and voluntary motion. The tentacula which are lomr and slender, are cloathed with numerous minute cilia, which are in a constant state of actirity. By their vibrations numerous currents pass over the ientacula and across the oral surface. Any insect or other substance coming within these currents, passes orer the mouth, and in so doing it is instantly caught by the prehensile lips, which are exceedingly sensitive, and couvejed to the stourach. 'Thus we see both oflices are performed by one set of organs, one being made subservient to the uther. These tentacuba, hise 


\section{6}

those of the two preceeding orders, are, according to Farre, tubular with terminal apertures.

The mouth, which is powerfully muscular, is situated in the centre of the oral disc, and opens into a long, large, tubular canal which terminates either in a gizzard or the stomach. This canal, which may be called an oesophagus, is powerfully muscular and very easily excited into action. When a polype has succeeled in capturing its food, it is conveyed into this oesophagus, which instantly contracts on it, and by a series of graduated contractions and relaxations forces it onwards under great pressure, to the gizzard or stomach. It is marked in different parts of its length, especially in its superior portion, by numerous closely arranged circular spots; at each extremity it seems more opaque than at any other part, as if its two openings were guarded by circular muscles; which is probably the case. In some species this canal opens into the stomach; but in others it terminates in a powerful organ which has been called a gizzard. This gizzard, from its inequalities of light and slrade, appears to be of unequal thickness; but there are always two dark spots, or circumscribed bodies, placed opposite each other. Sometimes the circumference of each of these spots is plain; at others marked with radiating lines, apparently formed of folds. After numerous examinations it seems to me most probable that muscular fibres radiate from these points over the whole organ, and consequently when they act, these points are brought into close approximation, and in their motions grind the food down to a pulp fitted for digestion; and such a distribution of fibres would also produce the folds occasionally seen. This organ opens inferiorly into the stomach, which is a long, large muscular sac extending to the base of the cell. It is semi-opaque, and very irritable; its surface is marked with minute irregular spots, which appear to be gastric follicles for the secretion of a coloured fluid for digestion. It is an organ, however which is liable to considerable variations in size, depending probably on the quantity of food in it at the time. It is fixed in its proper situation by thin flat muscles attached to different parts of its surface. This organ seems to perform the functions of the stumach and small intestines in higher animals; for the food remains in it longer than in any other organ, is digested there, and afterwards passes with great rapidity through the remaining tube. From the upper edge of the stomach arises another eanal which, ascends between the sides of the polype and the cesophagus, and terminates in a small orifice near the rim of the tentacula. In some species the gizzard is absent, in which case the first tube, or oesophagus opens into the atomach. 
The food in the stomach has a rapid rotatory motion while it remains there, and is conveyed through the terminal tube in the same manner. Dr. Farre in an elaborate and excellent article on this subject says this rotatory motion is effected by ribratory cilia, similar to those of the tentacula.

Even from this brief notice of the anatomy of the polypes it will be seen that they are considerably elevated above those of the foregoing orders; and their activity and intelligence are equally superior. When fully expanded and in search of prey, turning from side to side, with their tentacula in consiant and graceful action, they seem like animated flowrets; but the suddenness of their disappearance is almost beyond belief; more rescmbling the risions of a fairy tale than any reality. How this is effected will now be explained. The principle is alike in all the families, however widely they may differ in external sharacters. For the sake of brevity, it will, therefore, be described only as it occurs in the Vesiculariadr, \&c. The cells in this family for the most part, resemble grains of wheat in shape. In these, the polype hides itself. The inferior portions of the cells are iutlexibly horny, while the upper parts are thinner and more membranous. On the internal surface are distributed a few flat muscles, which are attached to different parts of the polype; thus for instance, one is attached to the base of the stomach and the base of the cell; others at the sides of the cell and to corresponding parts of the polype; their origins or fixed points always being below their insertions. These are the muscles which belong to the polype; there are others which belong exclusively to the cell. The upper portion of the cell, being membranous and flexible, is operated on by muscles which having their origins on the upper part of the inflexible portion of the cell, then ascend and are inserted into the thin edge of the orifice. Here then we see there are two sets of levers, arranged in the best possible manner for rapidity of elfect. By them the polype can be instantaneously withdrawn, and the opening drawn closely and tightly together.

The upper rim of the cell, when the polype is expanded, is found to be surmounted by a coronet of losg delicate bristles, whicb are held together by a membranous connection; and when the polype is withdrawn, these remain c'osely compacted in an upright position at the entrance of the cell. 'The muscles are composed of simple fibres, of nearly equal thickness throughout, and with but very slight attachments to each other. They are in fact the simplest form of muscle $I$ ever saw. This then is the mechanism of the rapid movements of the polype; but the way in which they protrule is not so clearly to be explained. The retractor muscles bemgr in a relaxed state, the sides of the polype which are also said to 
be formed of circular muscles, press on the fluid contained within the polype and force the weakest part, and consequently the creature ascends through the mouth of the cell; and Dr. Farre thinks that the stomach has a power also of lengthening itself, and so assisting the protrusion. But whatever power produces it, the expansion is very gradual. As the polype lies in the cell, it is drawn into an $\mathrm{S}$ configuration, and thus may be said to be packed away in a very small compass. It must not be supposed that all the structures here mentioned can be viewed in a single specimen; it requires a good microscope, good light, and repeated examinations; for at first all seems confusion. The polypidorns of this order vary greatly in size, appearance and structure. But although there have been reasons to consider the solid parts of the foregoing orders as organic, an opinion which is opposed by many, yet here their organic character is allowed, and the point need not therefore be enlarged on. The solid parts are here properly considered to be continuations of the external parts of the polype.

The arrangement of the horny cells of the first family varies; in some they are arranged in parallel companies, like Pan's pipes, in others in irregular clusters, and in a few they are without any definite order.

With the exception of those genera forming the family Vesiculariadæ, already mentioned, the whole belonging to this order are either calcareous or membrano-calcareous. Those species forming the genus Crisia bear a great reresemblance in form to the Sertularia, among the Hydroida; with which they were formerly associated. They are arborescent, and the centre of the trunk, branches and cells are occupied by a vital pulp, from which the polypes are developed. The polypes are thus united into one compound animal as in the first order. The growth of the polypidom is also similar in these widely separated genera, and as the reproduction is also by ovarian vesicles, nothing could be more natural than associating them together, if external characters alone were to be our guide; but the polype is widely different. The terminations of the branches and new cells are closed, but as developement advances the cells open, in a precisely similar manner to what has been noticed while speaking of the Hydroida. When the pulp has effected an advancement to the extent of an internode, it stops for a short period, and what was semi-membranous and pellucid becomes white and solid by the deposition of calcareous matter. But those parts which are membranous and pellucid while the creature is living, become after death very solid and brittle, arising probably from the crystalization of the calcareous particles, as soon as they are freed from the 
agency of life. The IIippothoa, and all the encrusting species grow very similarly. From one, and sometimes from three points in Hippothoa, a gelatinous transparent looking substance is effused of the length, breadth, and form of the future cell, and in this the lime is soon deposited in the form of a perfect cell. The Tubuliporida, from the earliest periods in which they can be observed have open mouths; in a very early state, the polype may be said to exist without a tube, since the calcareous portion forms but a base for the cell, but as the polype elongates the tube also increases in length.

Whatever opinion may be entertained regarding the polypidoms of the foregoing orders, those now under consideration are generally allowed to have an organic connection with the polype; but the evidence does not appear to be more conclusive here than in the other orders. In the Sea Mats (Flustra) and the kindred genera, the manner in which their organic vature can be ascertained, can be seen to the best advantage, and to these a trew observations will be directed.

The encrusting species vary a great deal in shape, which depends in a great measure on their different modes of growth. The Hippothoa has three points only from which growth takes place: the terminal, which is the most fruitful, and one on each side of the cell. At these points a semi-fluid transparent substance is effused, of the form of the cell; and hence in young specimens the cells are connected together like loosely strung beads. In old specimens, where each cell has had time to extend its growth from the three points, it greatly resembles an irregular Flustra. In the Flustra membranacea, an exceedingly delicate and guaze-like species, there appears to be only one spot for extension, which is not a point, for it extends over all the distal surface of the cells; but this gives rise to another which may be called accidental, since it arises from a peculiarity in the cell. The terminal or longitudinal increase is produced by an effusion of a semisolid gelatinous substance, which is called a pulp, and in which the cells are formed. This pulp extends to a certain distance, differing in different specimens, which marks the extent of the growth for one time. In a very short time after the pulp is effused, faint white or milky looking streaks are observed to traverse the pulp in a longitudinal direction so far as the pulp extends. These lines form the lateral boundaries of the future cells. At first the lines are faint, but they soon become distinct and well defined. Faint milky lines are then observed to pass transversely and thus divide the space into quadrangular compartments : these are much stouter than those first formed. 'The form of the cell now being completed, no further alteration takes place, but the further condensation of the sides and the formation of the 
hollow enlargements at the angles, which form their specific differences. So extentire is this effusion occasionally, that I have known ten inclies of cells in formation at one time. This form of growth fully explains the great length and the comparatively narrow extent to which this species attains.

In some, and indeed in almost all cases, where the length of the encrustation is great, the longitudinal lines of the cells have a gently arched direction outwards. This arises from the manner in which the lateral increase is effected, and which may be termed the intercellular increase. As the cells lie in their linear direction they gradually get wider as they get more distant from the centre of growth. In this manner every eiglith or tenth cell has so far increased in size, that two snaller ones are formed on its extremity; these also increase in breadth, and hence a continued intercellular enlargement takes place. The outer rows of cells are thus necessarily forced into the archer form, from these internal werges. This is the chief if not the only mode of lateral increase. If any obstruction is offered to the longitudinal growth, such as an orifice in the frond or any inequality of the surface, the cells will take a circuit and meet on the other side. If however the polypidom be injured laterally, a small quantity of the pulp will be effused there; and the cells formed in it will be in the direction of the effusion, or at right angles to the original source. So that the direction of the lines of the cells, is indicative of the point from which the pulp was effused. In the Hairy Sea Mat (Membranipora pilosa) a lateral increase takes place differently, but showing the same fact, that a calcareous deposit takes place in the pulp, and is but a continuation of the same process that caused the effusion of the matrix.

In the calcareous species, such as Cellepora pumicosa, Eschara, \&c., the formation of the cells is equally apparent; but changes occur in the character of the cells after they have acquired their specific markings, which tend still further to prove that the polypidoms are organic and liable to similar changes incident to other organic structures. In the encrusting calcareous species, the direction of growth appears to be diffused on all sides of the cells, and hence they generally grow in circumscribed patches. After the pulp has been effused, the lime is deposited in a similar manner to that des. cribed above, differing, of conrse, in some measure in the different species; in the Ilairy Sea Mat for instance, the cells pass through a series of changes, each of which is similar to the perfect cells of other species. After the pulp has been effused and the celis perlectly formed, the calcareons deposit is not from that time suspended, for after that period they considerably alter in appearance. The cells, 
which in their most perfoct condition are well defined and distinct from each other, become confuser, from having intervening depressions filled up with calcareous matter, and the interspaces or meshes on the surface disappear from the same cause. In this way all the specific characters are destroyed; the surfaces become plain and even, and the apertures look like minute orifices in a plain incrustation. 'The apertures, like the surface, loose their specific distinctions and become smaller, till by the continued deposit of calcareous matter, they become obliterated and the polypes thus become enclosed in graves of their own making. This being the case, a further effusion of pulp takes place on the surface of the destroyed cells; in it new cells and polypes are developed, to be again destroyed by the very process which gave them life. Thus we sce

6 The living pile ascend,

The mausoleum of its archirects,

Still dying upwards as their labours closed."

From these repeated obliterations it is, that many species become so irregular in shape; a remarkable instance of which is found in the common pumice stone coralline, (Cellepora pumicosa.)

We thus see that the external surface of the cells is perpetually undergoing changes of a very marked character. Is this consistent with an extravascular and inorganic character?

If these calcareous cells, in reality have no organic characler, but are merely formed by, or are an exudation from the pulp, or from a secreting membrane, it is evident, that after their first formation they could undergo no alteration eillier in form or character, except what wonld arise from a chemical or mechanical change in their structures. The external surface once forned, would remain for ever beyond the inflience of the polype within. If inorganic bodies be surrounded by highly organized tissues, life is sometimes sufficiently powerful to cause their removal. But in the case under consideration, the lime is not inoulded on the pulp, by a mantle, as in shells; but is formed in and by the pulp itself, and a coutinued deposition is yoing on. If the external layer be beyond the influence of life, the lime ought to be deposited on the internal surface as being most in contact with the exuding pulp, and thus, the carity of the cell would become filled and solid, rather than the fissures of the exterior. But the exact reverse of this is the case. In some species, such as Calepora cervicomis, and ramulosa, the Sea Mats; Eschara foliacea, and olhers, the whole process of formation, from the embryo, to the perfect and obliterated cells, can be observed; so that no dilliculty can arise for tiant of opporfunities to test these oputuons. In 
further confirmation of these views, it may be briefly noticer, that if the cells be placed in acetic or dilnte nitrons acid, all the carbonate of lime is removed, and the undoubted organic portion of the cells looks but slightly altered from what the cells were before the obliteration took place. If the experiment be reversed and a specimen be boiled in caustic potash, the organic matter is removed and the spongy calcareous case remains perforated or porous from the removal of the matter which formerly pervaded the whole. Thus then it seems clear that the polypidoms are organic.*

The mode of reproduction in this order varies a great deal, and in many genera it is entirely unknown. In the genus Crisia, which we have noticed as resembling Sertularia, it is effected by the periodic formation of ovarian vesicles. As the formation of these cells is very similar to that of those described among the Iydroida, little need now be said on the subject. In them the ova or gemmules are formed from the vital pulp, which at first occupies the whole of the cavity, but as developement advances, it is withdrawn towards the centre. It is of the same consistency as the pulp which traverses the centre of the polypidorn, and in fact is a continuation of it. It very soon becomes developed into globular gemmules, which are clothed with numerous vibrafory cilia, that are in constant action. By these, after the gemmules have escaped from the vesicle, they are whirled about in a rotatory manner through the surrounding fluid, like worlds in minature. Like the gemmules of the Hydroida they at last become fixed, and like them spring up into delicate and beantiful arboresence; but they are calcareous instead of horny. After having performed their functions, these organs drop off and disappear, or are thrown off like the leaves of trees in autumn. In the Hydroida it has been noticed, that these temporary organs are abundantly produced, and may, in one or other species be noticed at all sensons of the year; here, on the contrary, they appear to be of rare occurrence, for after long and attentive searches, two specimens only have been procured. This paucity of vesicles, howerer, may arise from the solid, calcareons, and friable nature of the structure; for as they stand on very slender forit-stalks, they nusst be incapable of resisting the violence of the sea. This however can hardly be the only reason, since many hindreds of specimens of each species, hare been examined at different seasons, in summer and after long continued calm weather, with but little

* This subject is further elucidated by M. Milne Edwards, Ann. des Sciences Nat., vol. 1, p. 25. Jolinston's Brit. Zooph., p. 327. 


\section{3}

success; it seem probable therefore, that they are but sparingly developed. The form of these organs is urnshaped, with short lubular orifices superiorly, which are placed a little on one side; inferiorly they contract into short and bent peduncles, which from their calcareous structure must necessarily be very brittle.

In some of the Sea Mats, the reproduction is also effected by what may be called ovarian vesicles. In the Flustra membranacea for instance at certain seasons of the year, long menbranous sacs are seen protruding from the cells; they are of a yellow colour semi-transparent, and filled with minute yellow granules which appear to be ova. They grow from the side of the cells; at first they are so small as to cause no apparent inconvenience to the polype; but as it increases in size the polype suffers considerably, and finally dies. The sac then occupies the whole of the cell. It is not in every cell that they are developed, for they are irregularly distributed over the whole polypidom. From the minnte and delicate nature of the polypes it is impossible, with our present means, to discover whetlier their formation depends on any peculiarity in the polype itself, or is the result of accidental causes. Frosn the irregularity of the developement, however, it seems to be governed by no law. Some authorities doubt that this is the true function of the sacs, but from what I have observed I have but little doubt on the subject.

In Tubularia and the kindred genera, the gemmules are formed interiorly, and may occasionally be seen escaping in the shape of minute ciliated grains, which move about freely from spot to spot, but shortly become fixed rooted and assume their adult specific forms. This mode of reproduction, observed so extensively among Zoophytes, is among the most curious in nature. In the first place we observe minute grains clothed with cilia which are in constant action, and by which they move freely about with ail the irregularity of roluntary motion; in the next they become rooted and grow into varions arborescent forms, endowed with unequivocal marks of animal life; changes which even the wildness of imagination would hardly have conceived. But if we turn to any department of nature, we sliall be surprised at the inexbaustable gradations of form and diversity of phenomena; and their almost miraculous termination in results and forms, the very best that could have heen devised for the situation each is destiucd to occupy in the scale of being. However obtuse our intellects may be, these things will force themselves on our attention; and to the naturalist, they form one of the chicf sources of his pleasures. 
This order is the most extensive of all and embraces great diversities of form, thongh a similarity of polype. If other shores are equally productive with our own, and many will be more so, it will have to be divided and sub-divided into small groupes if only for the convenience of study. At present no alteration is required, the system here adopted being quite sufficient for the convenience of future investigations.

\section{VESICULARIAD E.}

Polypidoms horny, fistular, confervoid; cells vesicular, deciduous, non-operculate.

\section{VESICULARIA.}

Generic Character: Polypidoms rooted, confervoid, fistular, horny, dichotomously branched, jointed at the divisions: cells ovate, disjunct, uniserial and unilateral. Polypes ascidian.

SILK CORALLINE. V. Spinosa. Stem erect, compound, branched dichotomously; cells on one side. Pl. xvii., fig. 1.

Conferva marina cancellata, Raii, Synop., vol. 1, p. 59. Sertularia spinosa, Ellis and Solander's Zooph., p. 48. Stewart's Elem., vol. 2, p. 446. Silk Coralline, Ellis' Coral., p. 20, pl. ix., fig. 17, B. Sertularia spinosa, Turton's Lin., rol. 4, p. 682. Laomedea spinosa, Lamouroux's Cor. Flex., p. 208. Templeton in Mag. Nat. Hist., vol. 9, p. 466. V. spinosa, Fleming's Brit. An., p. 551.

$H a b$. On corallines from deep water, off the Deadman, rare.

Confervoid, horny, fistular, and of a semi-transparent membranous texture; branched; branches long and zig-zag, slender and jointed. It is erect, slender and varies in height to eight inches. Cells three on each internode, deciduous; their situations in dried specimens are marked by round apertures. Polypes with eight ciliated tentacula.

SERIALARIA. Lamarck.

Generic Character: Polypidom confervoid, horny, the shoots slender, filiform, fistular, and branched; cells tubulous, uniserial, and unilateral, disposed in close parallel companies at regular intervals; polypes ascidian.

NIT CORALLINE. S. Lendigera. Polypidom delicate,

branched, spreading; cells in isolated groups, arranged parallel to each other, with waved patulous apertures. Pl. xvi., fig. 4, 5.

Fucoides lendigerum capillamentis Cuscutæ instar implexis, Raii, Synop., p. 38. Nit Coralline, Ellis' Coral., p. 27, 


\section{5}

no. 24, pl. 15, fig. b B. Sertularia lendigera, Ellis and Solander's Zooplı., p. 52. Turton's Lin., vol. 4, p. 682. Stewart's Elen., vol. 2, p. 445. Serialaria lendigera, Fleming's Brit. An., p. 547. 'Templeton in Mag. Nat. Hist., vol. 9, p. 467. Johnston's Brit. Zooph., p. 251, fig. 40, p. 219. Amathia lendigera, Lamouroux's Cor. Flex., p. 159.

Hab. On the roots of sea weed, about and beyond low water mark. Talland sand bay, Polperro, Lantivet and Lantic bays. "Goran Haven," Mr. Peach. Port Pean. Common.

The appearance of this coralline, as Dr. Johnston has said, "resembles a flock of hair with clusters of nits scaltered over it." The stem and branches are about the size of hair, hollow, and spreading dichotomously, jointed, the lower part of the joint pointed, the upper enlarged, and on this enlarged part, the cells are arranged in companies of from four to eight, and each cell is parallel 10, and in connection with the next. They resemblo "Pan's pipes" in miniature. The mouths of the cells are irregular.

VALKERIA. Fleming.

Generic Character: Polypidoms confervoid, lorny; cells ovoid, sessile, irregularly grouped together, with contracted terminal apertures.

GRAPE CORALLINE. V. Uva. Polypidoms creeping; cells irregularly distributed, apertures terminal. Pl. xvi., fig. 6.

Grape Coralline, Ellis' Coral., p. 27, pl. xv., fig. c ( 1 . Sertularia uva, Ellis and Solander's Zooph., p. 53. Turton's Lin., vol. 4, p. 682. Stewart's Elem., vol. 2, p. 415. Templeton in Mag. Nat. Hist., vol. 9, p. 466. Valkeria uva, Fleming's Brit. An., p, 551. Johnston's Brit. Zooph., p. 253.

Hab. Parasitical on the Sea-oak; abundant about October.

This species climbs over fuci and corallines, by means of its horny tubular fibres, and produces its cells at intervals, either singly, or in clusters, of from three to cight. 'The cells are large, and in shapo resemble grains of wheat; they are attached at one point below, and free at all the rest. The aperture is terninal and closed. The polypes liave eight ciliated tentacula. When living, the cells are smooth; when dried, they become wrinkled, as Ellis has figured thom.

VALKERIA IMBRICATA. Confervoid, horny, irregularly, but somewhat alternately branched; cells in irregular, and dense clusters, sometimes in single rows, urvid, Pl. xvii., fig. 2. 
Sertularia imbricata, Turton's Lin., vol, 4, p. 683. Stewart's Elenı., vol. 2, p. 450. Serialaria imbricata, Sertularia verticillata, Templeton in Mag. Nat. Hist., vol. 9, p. 467, fig. 66.

Hab. On fuci near low water mark. Polperro. Not common.

This is a small confervoid species of a light brown or horn colour, and is parasitical on different species of fuci near the shores. Its stem is formed of a semi-transparent zig-zag line, and gives off its branches very irregularly, but in somewhat an alternate manner. It is generally creeping and frequently covers a surface of several inches in extent, from which a few tufts arise erect. The cells arise irregularly on various parts of the polypidom, in dense clusters or in singlo rows; they are ovate with contracted terminal apertures and are deciduous. The stem and branches are frequently marked with round or oval apertures, which are the marks of cells which have fallen off. The polypes are very active and have eight ciliated tentacula, they appear to be very timid; they protrude themselves, so far as the tentacula very slowly, but afterwards quickly; but the least motion, or shade will make them contract in a very sudden and unexpected manner. The cells to be seen in a perfect state must be examined while the specimen is recent, for when it is dried, they frequently fall off and always look different from nature; this observation applies not only to this, but to all these horny fistular species, so that descriptions taken from dried specimens will not frequently apply to the living.

D.ODDER CORALLINE. V. Cuscuta. Creeping, slender, horny, branched; branches opposite, nearly perpendicular to the stem; cells ovoid, numerous, crowded. Pl. xvii., fig. 3.

Climbing Dodder-like Coralline, Ellis' Coral., p. 28, pl. 14, fig. c C. Sertularia cuscuta, Ellis and Solander's Zooph., p. 53. Turton's Lin., vol. 4, p. 680. Stewart's Elem., vol. 2, p. 444. Valkeria cuscuta, Johnston's Brit. Zooph., p. 252.

Hab. Parasitic, on fuci and corallines. Not uncommon. Polperro. Goran.

This species when nearly deprived of its cells, has all the appearances of Valkeria cuscuta as figured by Ellis; otherwise it bears but little resemblance to it. It is confervoid, horny, creeping and very slender. It sometimes attains the height of four inches, but is most commonly found about one or two. It arises from creeping tubular fibres which trail along on fuci and other marine productions. The branches are numerous, and frequently branch again; they are opposite and stand nearly at right angles to the stem. The whole 
polypidom is divided into internodes of nearly equal lengths, and about three times as long as the transverse diameter: these, however, are hardly visible but in dried specimens. The cells are oval, numerous, crowded, sub-pedunculated, and not congregated into companies. They are somewhat irregular in size, but are generally about twice as long as the diameter of the branch. The polypes are very active with eight ciliated tentacula.

There are several discrepancies between this account, and those given by Ellis, Fleming, Thompson and Johnston, but if we suppose their descriptions to have been taken from injured specimens, this in a similar condition closely resembles them, otherwise it must be considered a new species.

\section{CRISIAD AE.}

Polypidom calcareous, or sub-calcareous, branched, confervoid, jointed; the cells linked together in one or more series, distinct, tubular or elliptical, with a terminal or subterminal aperture, never closed with an operculm.

\section{CRISIA. Lamouroux.}

Generic Character: Polypidom confervoid, rooted by tubular fibres, dichotomously branched; the cells long and tubular, linked together in one or two series, the apertures round, terminal, and produced. Polypes ascidian.

\section{* Cells linked in a single series.}

GOAT'S-HORN CORALLINE. Crisia Cornula. Cells long and tubulous, with a curved termination, having a long bristle at the joint above each cell. Pl. 17, fig. 4.

Goat's-horn Coralline, Ellis' Coral., p. 42, no. 10, pl. 21, fig. c C. Cellaria cornuta, Ellis and Solander's 'Zooph., p. 25. Sertularia cornuta, Stewart's Elem., vol. 2, p. 449. Turton's Lin., vol. 4, p. 686 . Eucratea cornuta, Lamouroux's Coral. Flex., p. 149, no. 260. Fleming's Brit. An., p. 541. Crisia cornuta, Johnston's Brit. Zooph., p. 260, pl. 31, figs. 1 and 2. Templeton in Mag. Nat. Hist., vol. 9, p. 469.

Hab. On fuci and corallines, rare; on the sides of the Corwich crab mixed with Crisia eburnea, common. Polperro, Lake Rock, Mevagissey and Whitsand bays.

It is calcareous, confervoid, about balf an inch in height, and is formed of a single row of cells, bent near their apertures, and placed one above another; it is slender, erect, very brittle, alternately branched, and rooted by calcareous, tubular creeping fibres. Above the beaked termination of each cell is a long bristle, which is generally broken off in preserved specimens. The apertures of the cells are even 
everted, and all turned one way. Ellis figures some ovalshaped vesicles, arising from the base of the cells, speckled, with a small tube at the back; this is of rare occurrence, for I have never seen it.

I am inclined to think that two species have been included under this name. In Turton's edition of Linnæus, vol. 4, page 686, it is said, "Denticles alternate with a single hair on the top of each," and in Stewart "denticles alternate," whereas this species has only a single row of cells which are all turned one way, and Lamouroux hy placing it in Eucratea, makes it to have only one row, "Polypier phytoïde, articulé; chaque articulation composée d'une seule cellule simple et arquée; overture oblique;" and Fleming, "Branches consisting of a single row of bent cells." I have made these references because I have met with two speciniens, of what appeared at the time to be deformed specimens of this species, in which, although the cells night be sard to be uniserial, yet their bent necks and apertures, were alternately turned in opposite directions, and hence might be said to be alternate, and the bristles, instead of being above, were beneath the apertures, which would nearly correspond to the description of Linnæus and Stewart. BULL'S-HORN CORALLINE, C. Chelata. Cells in the form of a shoe; apertures oblique, with a slightly tubular rim, and a short tubular spine beneath. Pl. 18, fig. 1 .

Bull's-horn Coralline, Ellis' Coral., p. 42, no. 9, pl. 22, fig. b B. Cellaria chelata, Ellis and Solander's Zooph., p. 25. Sertularia loricata, Turton's Lin., vol. 4, p. 686. Stewart's Elem., vol. 2, p. 449. Eucratea loricata, Fleming's Brit. An., p. 541. Eucratea chelata, Lamouroux's Cor. Flex., p. 149, no. 201. Loricula loricata, Templeton in Mag. Nat. Hist., vol. 9, p. 409 . Crisia chelata, Johnston's Brit, Zooph., p. 261, fig. 43, p. 260.

Hab. On the roots of fuci, not common. On corallines, rare. Polperro; Lantivet and Whitsand bays. Goran Haven. Mr. Peach.

This is a very minute species, and is in its appearance, more singular, perhaps, than any other of the family. It is confervoid, calcareous, erect, and rises from minute tubular fibres which trail over the fucus on which it grows and root it to the spot. The first cellule which arises from the root is long, tubular, slender, with an everted neck, very much resembling a cell of the last described species. It is much and irregularly brapched and composed of a single series of cells arranged longitudinally one above another. The cells are shoe shaped, or they more closely, perhaps, resemble 
a Wellingion boot cut off at the neck, with the toe below and lieel above. The aperture is oval, subterminal, or like the opening of the shoe; in the dried state it has a thick, short, tubular rion, which in living specimens is not apparent. Beneath the rim there is frequently seen a short tubulous spine; this is the rudiment of another cell. 'This is proved by many specimens showing the different gradations to the perfect cell, and that all the branches arise from this situation, while the other cells are attached to each other by the lieel and toe. When the specimens are living, the cells are so transparent that the polype may be seen through; so that when tho animal is expanded two muscles are distinctly to be seen, one attached to the base and the other to the back of the cell, and the animal is found to be encased in a close tubular sheath, to which the muscles are attached, and which is partially protruded when the polype is expanded.

* Cells paired with a joint between each pair.

TUFTED IVORY COLALLINE. Crisia Eburnea. Cells loosely aggregated, cylindrical, bent, tubular; orifices free. Pl. 18, fig. 2 .

Tufted Ivory Coralline, Ellis' Coral., p. 39, table 21, no. 6, fig. a A. Sertularia eburnea, Turton's Lin., vol. 4, p. 686. Stewart's Elem., vol. 2, p. 449. Cellaria cburnea, Ellis and Solander's Zoopl., p. 24, no. 7. Crisia eburnea, Lamourous's Cor. Flex., p. 138, no. 244. Fleming's Brit. An., p. 540, no 156. Templeton in Mag. Nat. Hist., vol. 9, p. 468. Johnston's Brit. Zooph., p. 262, pl. 31, fig. 3, 4.

IIab. On the rools of sea weed, and the sides of the Corwich crab, abundant. Talland sand bay, Whitsand bay, Lantivet bay, St. Austle bay, Polperro, Port-Holland beach. On the crumb of bread sponge. Common.

This white calcareous zoophyte varies in height from one-fourth to one inch, and grows in white ivory tufts, many of which are sometimes united to each other at intervals by a creeping fibre. The polypidon is sometimes much branched, ard always in an alternate manner. The cells are biserial, lubular, with free apertures, are loosely aggregated, and nearly opposite. They are frosted, or marked with minute dots with plain transparent centres. In young specimens, the branches all arch inwards, and give the small tufts a pretty appearance. The vesicles are very rarely to lie found. They are rough or frosted, and somewhat urnshaped with narrow tubular necks, which are not placed in the centre.

BLACK JOIN'TED CORALLINE. Crisia Luxata. Cells closely aggregated, cylindrical, nearly straight, wilh short tubular orifices; joints black. P1. 18, fig. 3 . 
Crisia luxata, Fleming's Brit. An., p. 540. Johnston's Brit. Znopl., p. 262, pl. 31, fig. 5, 6 .

Hab. On the roots of sea-weed, corallines, back of the Corwich crab, very common. Lantivet bay, Talland sand bav, Polperro, Whitsand bay.

This species bears a very close resemblance to the last. It is calcareous, jointed, erect and about one inch in height; it grows in small and elegant tufts which are united to each other by hollow, calcareous, black jointed tendrils. The root, immediately below the first internode is straight and narrow, but above is large and globular and from its inferior surface numerous slender jointed tendrils proceed, embracing the surface on which it grows and firmly root it to the spot. It is dichotomously branched, and in young specimens, the branches all arch inwards. The cells are biserial, semi-alternate, tubular, adnate, frequently rough or frozen, and speckled. The apertures are oblique, and slightly uneven. The joints are black, which give the polypidom a speckled appearance; the internodes are of various lengths and bear an unequal number of cells; below, they are narrow and gradually dilate into the two lower cells. Beside the bollow tendrils which form the roots, others arise from various parts of the polypidom near the joints, which are also holluw, jointed, and assist the rooting the polypidom to the spot.

This is a more robust species than the last, and has its joints always black. The cells are sometimes prominent and the apertures divergent, as in the Crisia eburnea, but as it is always black jointed and much stouter it cannot be mistaken.

NOTAMIA. Fleming.

Generic Character: Polypidom plant-like, sub-calcareous, rather soft and flexible when dry; dichotomously branched; cells opposite, united by the back, a joint above and below each pair.

COAT OF MAIL CORALLINE. Notamia Loriculata. Cells sub-cylindrical and obliquely truncated; apertures plain. Pl. 18, fig. 4 .

Muscus coralloides mollis elatior ramossissinus Raii, Synop.. vol. 1, p. 34, no. 6. Coat of Mail Coralline, Ellis' Coral., p. 40, no.7, pl. 21, fig. b B. Cellaria loriculata, Ellis and Solander's Zooph., p. 24. Sertularia loriculata, Turton's Lin., vol. 4, p. 684. Stewart's Elem., vol. 2, p. 447. Notamia loriculata, Fleming's Brit. An., p. 541. Johnston's Brit. Zoopb., p. 263, pl. 30, figs. 12 and 13.

Hab. Near the shores, rare. Polperro. R. Q. C. Goran Haven, Mr. Peach. 
This species on our coast attains about three inches in height, but is more commonly found about one. It is of a light brown colour, and though much and dichotonously branched, is not spreading, growing much like a poplar tree; the branches are slender and formed only of the cells, which are united in pairs, with a joint between each pair. The cells are opposite, united at their backs, smooth and obliquely truncated. The appearance of the cells thus united is aptly said by Ellis, " to resemble a coat of mail or pair of stays; and the entrances of the cells look like the places for the arms to come out at." The polypes have ten ciliated tentacula, and are very active.

\section{HIPPOTHOA. Lamouroux.}

Generic Character: Polypidoms confervoid, adherent and creeping, calcareous, irregularly branched, the branches frequently anastomosing, formed of eliptical cells linked to each other at the extremities; aperture lateral, near the distal end. Polypes ascidian.

BEADED CORALLINE. II. Catenularia. Cells eggshaped, smallest end towards the centre of growth; aperture large, oval, and at the larger end. PI. xviii., fig. 5.

Hippothoa catenularia, Fleming's Brit. An., p. 534. Johnston's Brit. Zooph., p. 264, pl. 31, figs. 9 and 10.

Hab. On the Pinna ingens and P. rotundata, very common. Polperro; Deadman point.

This is to be found on almost every Pinna drawn from deep water off the Deadman point, and west to the Lizard. It is a small bead-like coral, running over the surface of the shell. It is adherent throughout, and formed of egg-shaped cells linked together at their extremities. The larger end, placed distally, is occupied by the aperture, which is oval, and sometiues very large with a plain thickened rim. As it trails over the surface of the shell it is much and varionsly ramified. The ramifications arise at nearly right angle's from the margins of the cells opposite the lower margin of the orifice, and frequently cover two or three inches of surface. Sometimes the celis are so thickly arranged as to be placed in juxtaposition over half an inch of surface, in such a case it very closcly resembles a Flustra; and on three occasions it was only by examining the free cells of the circumference that the character of the polypidom was determined. When thus jointed into a Flustra-like form, the cells appear inflated, and the apertures immersed; sometimes the surface is smooth and the situation of the cells only marked by the rounded apertures. In its more usual form it is varionsly ramified and resembles, as Dr. Johnstou has 
said "many of the plant-like figures in marble and agate." When recent, the cells look in a reflected light like minute pearls, and may then easily be removed from the shell to which they are attached.

SMALLER-BEADED CORALLINE. H. Lanceolata.

Cells small, slender, and ovoid; aperture round, very small, and nearly terminal. Pl. xriii., fig. 6 .

Hippothoa lanceolata, Johnston's Brit. Zooph., p. 265.

Hab. On the Pinna ingens off the Deadman point, common. $R$. Q. $C$.

A very similar species to the last, but much moro delicate. The cells are very minute, pearly, translucent, ovoid, and not so much bulged distally as in the last. The mouth, which is scarcely visible even under a pocket lens, is round, with a raised margin, and nearly terminal. The cells are distant, and connected with each other by a very slender white thread of about twice the length of the cell. It is much and irregularly ramified, each branch is given off at the side and about the middle of a cell. This species retains its pearly lustre even when preserved in cabinets. It is so minute, that it would entirely escape observation if it was not especially looked for, or if the surface was not examined attentively with a lens. It is as common as the last species, and found on the south coast, wherever the Pinna occurs.

HIPPOTHOA SICA. Encrusting; calcareous; cells spear shaped; large end placed distally; apertures small subterminal. Pl. xix., fig. 9.

Hab. On stones from deep water, common. Polperro, Goran.

This species of Hippothoa differs so decisively from the two described above, that there can be no doubt of its being specifically distinct. The cells are calcareous, enlarged, and rounded at the distal, and pointed at the proximal end. Their direction is linear; they are attached to each other at their extremities, and their length is about four times their transverse diameter. This species is more sparingly branched than the others. The branches arise at right angles to the cells, from the sides of the apertures. The apertures are rather sinall, and, as usually seen, are round, even, and unarmed, but, in recent and living specimens, they are long and tubular: frequently as long as the cell. In this state it may be taken for a species of Tubulipora.

ANGUINARIA. Lamark.

Generic Character: Polypidom calcareous, creeping, adnate, slender, fistular; the cells scaltered, erect, free, spathulate, with a lateral aperture near the apex. Polypes ascidian. 


\section{3}

SNAKE CORALLINE. A. Spatulalu. Pl. xix., fig. 2.

Snake Coralline, Ellis' Coral., p. 43, no. 11, pl. 22, fig. c C D. Cellaria anguina, Ellis and Solander's Zooph., p. 26. Sertularia anguina, Turton's Lin., vol. 4, p. 686. Stewart's Elem., vol. 2, p. 449. Cellaria anguina, Templeton in Mag. Nat. Hist., vol. 9, p. 466. Anguinaria' anguina, Fleming's Brit. An., p. 542. Anguinaria spatulata, Jolnnston's Brit. Zooph., p. 266, pl. 31, figs. 7 and 8.

Hab. On shells occasionally, but more frequently on the smaller sea-weed. Polperro, Talland sand bay, Looe island, Mevagissey bay, \&c.

Creeping; cells arising from a creeping fibrile, erect, free, and calcareous; they resemble spoons which have the bowl bent with the concave portion towards the handle. That part of the creeping fibre from which the cells arise, is enlarged and bulbous; under the microscope the cells appear to be circularly striated, as it is figured by Ellis. The enlarged and bent heads of the cells are dotted, and frequently infested with minute Confervæ. The apertures are subterminal, inferior, and ovoid. When dead it is of a pure white colour, when living of a delicate pink. This minute species, though not abundant is common, especially in the latter part of Summer and Autumn.

\section{TUBULIPORID E.}

Polypidoms calcareous, or membrano-calcareous, variable in shape but never confervoid; cells tubular, rising from a baso and projecting; the apertures terminal and non-operculate.

\section{TUBULIPORA. Lamarck.}

Generic Character: Polypidoms attached by a partial or entire adhesion of the base, sometimes crustaceous; cells placed on a calcareous basis, arranged in rows, long and cylindrical, separate with an erect aperture. Polypes ascidian,

WART-LIKE CORALLINE. T. Patina. Centre cupped, circumference plain, midway betwcen raised, and bearing erect tubes with round unarmed apertures.

Millepora verrucaria, Ellis and Solander's Zooph., p. 137. no. 13. Madrepora verrucaria, 'Tuston's Lin., vol. 4, p. 616 . Stewart's Elem., vol.2, p. 426. Discopora verrucaria, Flem. Brit. An., p. 530. Tubulipora patina, Johnston's Brit. Zooph., p. 267, pl. 30, figs. 1, 2, and 3.

Hab. On the Pinna ingens, stones, corallines, and deadman's hands, from deep water, common.

This small wart-like species is liable to many variations of form arising from the difterent developenent of its various 


\section{4}

parts. It may, for the sake of convenience in noticing these variations, be said to be composed of three parts, a central or depressed portion, crowded with cells, a raised or prominent circle round the centre, formed of erect or semi-erect aggregated tubes, and a thin, plain, translucent margin destitute of cells.

In form it very snuch resembles a miniature soup-plate. It is calcareous, white, sessile, rarely exceeding half-an-inch in diameter, and is attached by the base of the central depression. The depression varies in size from a mere point to about three-eighths of an inch in diameter, and is either round, or very irregularly oval. The surface is occupied by small, semi-horizontal, closely aggregated tubes, with oblique even apertures. The raised circle is also liable to great variations in form. In most cases the tubes rise abruptly from the circumference of the depression, forming well defined fluted sides to the cup; sometimes they rise in gradual succession one above another, forming a gently sloping surface from the margin to the centre; sometimes the surface is arched concavely, at others convexly, and between these extremes there is every possible variation. The sides of the cup are generally unifornily fluted, a furrow being formed by each tube; but sometimes the tubes are arranged in companies, and then, the sides appear formed of fluted columns. The tubes are of equal diarneter and lean in a greater or less degree, obliquely outwards. The apertures are generally on one plane, but occasionally rise in radiating ridges; but some will rise singly above the others. The apertures are even and oblique; but sometimes, if the specimen be examined as soon as it is taken, the apertures appear armed with one or two spines, but this appears to me the result of the greater growth of one side of the lip than of the other, for their situation is by no means constant, they are often absent, and always form a continuation of the sides of the tubes. The third or external part is frequently wanting. In its greatest developernent it is about as wide as the middle or raised circle of tubes; it is calcareous, translucent, very thin and radiatingly striated with the rudiments of tubes, which are thickly arranged, though never in contact. They however sometimes branch and anastomose with each other. In a very recently formed portion of this margin, these tubes do not extend quite to the circumference, but as age advances they get more and more elongated till the whole surface is permeated by them; so that at first they appear pointed but afterwards of equal diameter throughout. That portion of the surface which is next the circle of tubes is always occupied by partially formed apertures of new tubes, and from examining large numbers of specimens from all 


\section{5}

that part of the English channel formed by the Cornish coast, it appears that this plain, translucent circumference is the earliest visible process in the formation of new tubes. But though thus liable to so many variations, it must not be supposed that the species is to be with difficulty recognized. It vory rarely occurs that more than one variation is found in a single specimen; and all the varieties differ from a standard form; so that it is as easy to distinguished this as any other species.

TRAILING CORAL. Tubulipora, (trahens, R. Q. C.)

Polypidom calcareous, creeping, adherent throughout, irregularly and sparingly branched, narrow, with one or two rows of tubes projecting from the upper surface. Pl.xix., fig. 3.

Hab. On stones and shells from deep wator, not uncommon; Polperro.

The polypidom varies-from a quarter to one inch in length, but is very narrow and slender. It is adherent throughout, trails over the surface of the stones or shells on which it grows, and is tortuously, sparingly, and irregularly branched. The tubes are commonly single, but sometimes are in pairs, and project considerably, sometimes in a straight and at others in a waved manner. When the tubes, are in pairs they are always close together, but each pair is separated from the next in the length ways of the polypidom by an interval varying from one-eighth to one-fifth of an inch in different specimens. Being unable to refer this to any described species, I have provisionally given it the name of trahens as descriptive of its habit.

SMALL PURPLE ESCHARA. T. Serpens. Polypidom

calcareous, purple or white; branches bifid, revolute; cells only on one side, long and tubular, in transverse rows separated by a central groove. Pl. xix., fig. 7 .

Small Purple Eschara, Ellis' Coral., p. 74, no. 6, pl. 27, fig. e E. Millepora tubulosa, Ellis and Solander's 'Zooph., p. 136, no. 11. Millepora liliacea, Turton's Lin., vol. 4, p. 639. Tubipora serpens, Turton's Lin., vol. 4, p. 614. Stewart's Elem., vol. 2, p. 426. Millepora tubulosa, Stewart's Elern., vol. 2, p. 428. Tubulipora serpens, Flening's Brit. An., p. 529. Johnstou's Brit. 'Looph., p. 268, pl. xxx., figs. 4 and 6 .

Hab. On stones, shells, corallines, and sponges, common at all distances. R. Q. C. Pallas.

This species is common at all seasons, and is generally parasitical un the horuy corallines, more particularly on the 


\section{6}

Plumularia falcata; on which it is very frequently abundant. It is a small calcareous species and generally of a purple or purplish white colour. It grows on a narrow base, is creeping, and dichotomonsly branched in a revolute manner. The cells or tabes arise from the upper surface only, the lower being plain or only siriated from the position of the cells above; they rise in two rows from near the centre of each branch and diverge towards the sides, leaving a central groove which runs through all the branches and gives the polypidom a remarkable and characteristic appearance. The tubes are very prominent, and occasionally distant, with plain round apertures.

If a specimen grows in an unfavourable situation, it will sometimes be curiously distorted. I have specimens which have grown in the crevices of stones in which the branches have been so closely pressed together that they seemed, at first view, as if united into one mass; but an examination soon discovered the branches and the two rows of tubes. In others there have been no branches and the polypidoms hare had a simple flat surface, but the peculiar leaning of the tubes was present in all. It varies in length from one quarter to half-an-inch in length; but on one occasion it attained three quarters of an inch and was the largest I ever saw.

TUBULIPORA PHALANGEA. Encrusting; polypidoms divided into from two to five lobes; tubes divergent from a central line running through the centre. Pl. xix., fig. 8.

Hab. On stones and the wicker work of crab pots, in from ten to twenty fathoms water, common.

This species in its most simple state resembles a deformed condition of Tubulipora serpens, with which it has hitherto been confounded. Having examined a great number of specimens from different localities, growing under different circumstances, I am induced, now, to consider them as distinct. It is encrusting, circumscribed, oval, and the oval is divided at the margins into from two to five lobes or festoons. Through the centre of each lobe runs a line or depression, from which the tubes diverge on either side as in Tubulipora serpens. The tubes are comparatively long, and are not in contact with each other as viewed from above. They are numerous and arranged in perpendicular rows; each row is formed of a single series of tubes, which are in contact with each other; each bring united to the one above and below. This arrangement presents the appearance of a number of Pan's pipes placed perpendicularly, the sets being separated from each other. 
$\boldsymbol{T}$. serpens is a branched species and is generally parasitical on other corallines, while this is an encrusting species and never branched. In the former the tubes are short and in contact, in the latter long and separated from each other, hence there can be no doubt of their being specifically distinct.

TUBULIPORA. (deflexa, R. Q. C.) Polypidom erect, cylindrical, with waved tubes projecting from all parts. Pl., xix., fig. 5.

Hab. On slells from deep water, common. Polperro, Mevagissey bay, and off the Deadman point.

This small species varies in height from a quarter to halfan-inch. It is calcareons, white, columnar, and unbranched; its upper termination is very frequently enlarged into a globular head. The tubes observe no regularity in their arrangement, but arise willsout order from all parts of the polypidom and project considerably in a bent or tortuous manner. They are shorter below than abore, nost probably from the older portions being broken off, and the apertures are even and unarmed. The base is slightly spreading and firmly adherent. Though this species is so common as to he found at all depths, yet I cannot find it referred to by any of the authorities to which $I$ hare access.

TUBULIPORA. (fungia, R. Q. C.) Pedunculated; tho upper portion expanded into a flat round surface; tubes projecting from the upper part of the circumference; centre nearly plain. Pl. xix., fig. 4.

Tubipora pennicillata, Turton's Lin., vol. 4, p. 615.

Hab. On shells and stones from deep water, comnon; from the Eddystone Lighthouse to the Deadman point.

This pretty species is calcareous, and varies to a quarter of an inch in height. The upper portion is expanded into a flat head, having on its superior surface, one, two, or three rows of projecting tubes round the circumference; the centre is either plais or marked witis a few irregular cells. The celis are distant from each other, with slightly oblique, unarmed apertures, and lean towards the circumference of the flat surface. Sometimes they are almost eren with the surface, and at others project so considerably as to hide all the surface of the disc except the central plailis spot. The tubes are rather small in calibre. This species is rery common in deep water, and though sometimes fonnd on shells, most commonly prefers thin slate or a red compound miva looking stone. 
TUBULIPORA OBELIA. Encrusting, calcareous, adherent throughout; cells tubulous, disposed in a radiating manner, generally semi-circular.

Tubulipora obelia, Johnston's Brit. Zooph., p. 269, pl. 30, figs. 7 and 8.

Hab. On stones and shells from deep water, common, from the Ram Head to the Deadman.

This is entirely an encrusting species. It is circumscribed in its base, and semi-transparent. The tubes are distant, recumbent, tubulous, and radiating from several centres, with semi-transparent inter-tubular spaces. The tubes are most commonly recumbent, as just described, but differ in their appearances; sometimes they are erect, at others semierect, and again either prominent or immersed; and in some specimens all these varieties occur together.

TUBULIPORA HYALINA. Encrusting, semi-transparent, membrano-calcareous; cells distant from each other, tubular, erect, arranged in one or two circular rows round a plain centre; apertures, unarmed and frosted. Pl.xix., fig. 6.

'Tubulipora hyalina, 9th Annual Report of the Royal Cornwall Polytechnic Society, p. 73.

Hab. On Fucus palmatus, rare. Polperro.

This small species encrusts the margins of sea-weed in patches of about the diameter of a pea. The tubes are distant, erect, immersed in the surrounding structure, of equal diameter throughout, and arranged in one or two rows round a plain centre; sometimes there are a few cells irregularly scattered in the centre, but separated from the external set by a plain surface. The apertures are even, un. armed, and of a milky appearance. In the Report of the Royal Cornwall Polytechnic Society, I have refered this species to the Berenicea hyalina of Fleming and Jolnston, though I had doubts of its correctness; since then the latter of these Gentlemen has informed ine that his species is nut a Tubulipora; this therefore is a new species; the specilic name of Hyalina is retained as descriptive of its general appearance.

DISCOPORA. Larmarck.

Generic Character: Polypidom calcareous, adherent throughout; the base a circumscribed crust; the cells coalescent, indistinctly quincuncial, tubular, erect, with a round patulons terminal aperture without an operculum. Polypes ascidian. 


\section{9}

DISCOPORA HISPID $\Lambda$. Encrusting, with a circumscribed base, calcareous, ridged or waved; cells coalescent, erect; apertures natulous, armed with one larger and two smaller teeth. Pl. xix., fig. 1.

Discopora hispida, Fleming's Brit. An., p. 530. Johuston's Brit. Zooph., p. 270, pl. 30, firs. 9, 11.

Hab. On shells, stones, and corallines, from deep water, common. Polperro, Fowey, Goran, \&c.

This very common species rarely exceeds an inch, but is most commonly found about one-half or three-fourths of an inch in diameter. It is calcareous, white, and from the juxtaposition of the tubes, very solid. It is not a mere incrustation, for it sometimes attains the thickness of half an inch, hut is most commonly about the tenth of an inch in depth. The surfaee is most commonly uneven, either with gently undulating ridges or papillary eminences; and as the tubes are so small that they cannot be distinctly seen with the naked eye, it looks like a piece of white embossed velvet. The tubes are irregular in size, erect, or but slightly leaning, and the ridges or unevenness of the surface is produced by their unequal growth. The apertures of the tubes are patulous, and sometimes even and unarmed, though most commonly arined with two or three stout conoidal spines; which is probably the manner in which the tubes grow in length.

\section{CELLEPORID A.}

Polypidoms calcareous, or membrano-calcareous, lobed, ramous or crustaceous, formed of an aggregation of cells disposed usually in quincunx; cells utricular, in justa-position with contracted terminal apertures, often covered with an operculum.

\section{CELLEPORA.}

Generic Character: Polypidoms calcareous, or membranocalcareous, cellular, lobed, ramous, formed of urceolate cells heaped together, or arranged in a quincunx. Polypes ascidian.

CELLEPORA VITRINA. Encrusting, calcarcous; cells ovoil, very small, pearly, and irregularly arranged. P'l. xxii., fig. 1.

IIab. On stones in moderately deep water, not rare. Goran, Mr. Peach. Polperro. Mount's bay.

This delicate and beantiful species, is very small; it is encrusting, circumseribed and rarely exceeding a quarter of an incls in diameter. The cells are small, transparent, vitreous or pearly in their appearance and very irregularly 
arranged. The apertures are very minute, and terminal, and cannot readily be seen oven with a lens.

PUMICE-STONE CORALLINE. C. Pumicosa. Encrusting, cells ovoid or sab-orbicular, generally heaped irregularly together, when young arranged in a quincunx; apertures round, arned with three marginal teeth. Pl. xx., fig. 3.

Porous eschara, Ellis' Coral., p. 75, pl. 27, fig. f F., pl. 30, fig. d, D. Cellepora pumicosa, Turton's Lin., vol. 4, p. 640 . Stewart's Elem., vol. 2, p. 428, pl. 12, fig. 16, 17, copied from Ellis. Fleming's Brit. An., p. 532. Templeton in Mag. Nat. Hist., rol. 9, p. 469. Johnston's Brit. Zooph., p. 273, pl. 32, figs. 1, 2, 3. Bellany's Nat. Hist. of South Devon. Millepora pumicosa, Ellis and Solander's Zooph., p. 135. Turton's Lin., vol. 4, p. 639. Stewart's Elem., vol. 2, p. 428. Flustra bullata, Ellis and Solander's Zooph., p. 16. Stewart's Elen., vol. 2, p. 436. Turton's Lin., vol. 4, p. 664 .

Hab. On stones, shells, and roots of sea-weed, common. Polperro.

This very common species presents itself under a variely of aspects, depending on the character of the substance it incrusts. As it is nost commonly found on Corallines, it generally resembles globular pieces of pumice-stone, from whence it derives its name. When living it is of an orange red colour, and sometimes pinkish; but when seen in collections, it is of a light dusky brown colour. It is calcareous, porous, friable, and encrusting. The cells are ovato-globose, round, or egg-shaped, depending on the figure of the substance it encrusts. The apertures of the cells are armed with three marginal teeth, which, from being easily destroyed, are not always to be found. In young specimens, encrusting a plain surface, the cells are always egg-shaped, and regularly arranged in a quincunx; but as age advances, the first layer of cells becontes irregularly covered with others of a newer formation. As this irregular accumulation of cells is constantly going on, the porous friable mass, commonly seen, is formed. There is a variety sometimes found on shells, which, when living, has a pearly appearance, which seems to be the Flustra bullala of Lincæus and Ellis.

BRANCHED CELLEPORE. C. Ramulosa. Polypidom calcareous, dichotomously branched; the branches cylindrical, rough, and obtuse; cells irregularly distributed; apertures armed with a spine on the outer lip.

Cellepora ramulosa, Turton's Lin., vol. 4, p. 640. Fleming's Brit. An., p. 532, no. 131. Johnston's Brit.Zooph., p. 274, pl. 32, figs. 4 and 5 . 
Hab. Lizard point, Polperro, Goran, Deadman point; common on corallines and stones, from deep water.

This, though a common, is not an abundant species. It is calcarcous, and while living, of a delicate flesh colour, which afterward changes to a dull white. It arises from a spreading base by a stont rough cylindrical trurk, and is dichotomously branched. The branches are short, stout, cylindrical, very rough, and the terminal ones end in obtuse points. The cells are numerous, urceolate, and in the young state, appear to be quincuncially arranged, but afterwards to be without regular order. The apertures are contracted, and armed with a long stout spine on the outer inargin. It varies in height from one to three inches.

C. SKENEI. "Much compressed, divided in a bifid manner, rough; cells rowed, with a strong mucro on the outer edge of the aperture." Skene.

Millepora Skenei, Ellis and Solander's Zooph., p. 13.5. Turton's Lin., vol. 4, p. 635. Stewart's Elem., vol. 2, p. 427. Cellepora palmata, Fleming's Brit. An., p. 532. Johnston's Brit. Zooph., p. 274, pl. 32, figs. 6, 7, 8.

$H a b$. On stones and the Pinna ingens, off the Deadman, rare.

This is a smaller and more compressed species than the last and rarely exceeds half an inch in height. It is sparingly and dichotomously branched; the branches are short, palmate, and truncated. The cells are urceolate, rather immersed, except in the newest parts, and somewhat spirally arranged; the apertures are slightly oval, but are in a great measure hid by a strong stout spine on the outer lip. This shape and arrangement of the cells give them a resemblance to a fir cone, in which the scales are loosely arranged.

STAG'S-HORN CORAL. C. Cervicornis. Polypidom calcareous, much and irregularly branched; branches palmate, truncate, marked with small pores, quincuncially arranged.

Millepora cervicornis, Turton's Lin., rol. 4, p. 635. Stewart's Elem., vol. 2, p. 427. Porus cervinus, Burlase's Nat. Hist. of Cornwall, p. 240, tab. 21, fig. 7. Cellepora cervicornis, Fleming's Brit. An., p. 532. Johnston's Brit. Zuoph., p. 276. Bellamy's Nat. Hist of South Devon, p. 269.

IIab. On stones and rocks, from deep water, common. Polperro, Goran, Deadman Point.

This species, in its general appearance, resembles a stag'shorn. It is calcareous, and irregularly branched. The baso 
is short, stout, round, and frequently distorted into rounded protuberances. The branches are compressed, especially towards their terminations. Except the terminations of the branches, the whole of the surface is roughly granular, from the irregular growth of the cells. The cells are urceolate, partially imbedded, and distributed over all parts of the polypidom. The apertures are round, with a notch on the inferior margin and an obscure wave on the superior one. At the termination of the branches the surface is smooth; the apertures of the cells only appearing. The granular surface is produced by the super-position of cells on the plain first layer. When living, the polypidom is of a delicate flesh colour, which afterwards changes to a dusky brown; and it frequently has a varnished appearance. Borlase, in bis Natural History of Cornwall has a characteristic figure of this specses but the figure given by Dr. Johnston is so entirely unlike any specimen of the great number I have procured, that it seems to be a distinct species approaching to Eschara. In this opinion I am supported by several friends to whom I have submitted specimens for comparison with the Doctor's figure.

C. LAEVIS. Calcareous, dichotomously branched, cylindrical; cells urceolate, somewhat quincuncially arranged; apertures round, with a mucro on the outer lip.

Cellepora lævis, Fleming's Brit. An., p. 532. Johnston's Brit. Zooph., p. 2\%\%.

Hab. On stones, off the Deadman Point, common.

This calcareous coral attains occasionally the height of two inches, but it is more commonly met with about one. In a living state it is of a reddish flesh colour, or pink, which always fades in death, and sometimes becomes of a pearly white tint. It is stout, slightly compressed, rough and dichotomously branched. The roughness, which is confined to the branches, is produced by the formation of new cells, with a mucro at the proximal lip. Inferiorly the stem is smooth, the intercellular spaces being filled up with calcareous matter, and the apertures of the cells appear as minute punctures, resembling openings on the terminations of the branches of the Stag's Horn Coral. Superiorly, the cells appear as if thrown on one side, and the apertures are slightly prominent; and this appearance of the lateral declination of the cells is still further increased by the large spine being placed on one side of the median line and leaning externally.

It is by no means uncommon on stones from deep water, in con pany with C.cervicornis, which it somewhat resembles; but is whitcr, more delicate, and less branched. 


\section{3}

LEPRALIA. Jolnston.

Generic Character: Polypidon calcareous, or membranocalcareous, adnate, crustaccous, spreading circularly, formed of a layer of urceolate cells in juxtaposition, and arranged in a quincunx; aperture terminal, often corered with an operculum. Polypes ascidian.

L. PEDILOSTOMA. Encrusting, calcareous; cells oroid, alternate, frosted, with a stout spine on the upper surfice; apertures terminal, round, unarmed. P!. xxii., fig. 14.

IIab. On stones about one mile from the shore, common; Polperro. Goran. Mr, Peach. Falmouth.

'This, with several of the following species, are here described for the first time. They have long lain by me, but as they could not be satisfactorily refered to any described species, they were omilted in the Report of the Cornwall Polytechnic Society, till their specific differences could be decided on. Having been supplied with a collection from various localities by my friend Mr. Peach, and liaving compared them with those in my own collection, they prove to he distinct; and the one now under consideration has been named pedilostoma by Mr. Hassal.

It is very commonly found encrusting the stones used by the crab-catchers in mooring their crab-pots, in patches varying from one quarter to one incli in diameter. 'The colls are oval, and horizontal, and their surfaces granular or frosted; on the lateral and upper portion is a short stout spine removed from the aperture about one fourth of the length of the cell. The spine is short, but has a spreading base, and is sometimes placed laterally and at others immediately in front. The apertures are round, unarmed, and terminal. It frequently happens that small circular orifices are scattered over the polypidom, in the inter-cellular spaces, as if a few cells bad been abortive.

L. PUSTULATA. Encrusting, calcareous; cells oroid, alternate, in radiating lines; apertures semi-circular, with a prominent rim. Pl, xxii., fig. 2.

Ilab. On stones and shells. Polperro. Goran, Mr. Peach.

This species occurs in encrusting patches of about three fourths of an inch in diameter. It is calcareous, adnate, with oval cells a!ternately arranged in radiating lines. The aperture is semi-circular and prominent, or formed by a tubular rim. The proximal lip is either straight, or slighlly arched into the carity of the mouth, and near it is a conoidal tubercle, which lies immediately in front; and this is among the earliest portions that become solidilied. Wiul the exception of this tubercle, the surface, in old specimens, is nearly smooth; but in young oncs it is minutely granular. 


\section{4}

L. NITIDA. Encrusting; cells ovoid, in juxtaposition, with transverse calcareous bands reaching to the median line; apertures oval. Pl. xxii., fig. 3.

Berenicea nitida, Fleming's Brit. An., p. 533. Lepralia nitida, Jounston's Brit. Zooph., p. 277, pl. 34, fig. 7.

Hab. On stones and shells, not very rare. Polperro, Goran, Mr. Peach.

This pretty species rarely exceeds half-an-inch in diameter. It is cncrusting, calcareous, and composed of urceolate cells, placed in juxtaposition. When living it is either of a yeliowish flesh colour or intermediate to a silvery white; but when dead it is dull. The cells though closely approsimated are not always arranged in the same order; sometimes they lie in radiating lines in an alternate manner, the centre, or body of one cell being opposite to the junction of two in the next row; at others in circles round one centre, and sometimes in an irregular alternate manner, or in no order at all. The Eurface of the cell is furrowed by from five to nine transverse calcareous bands; they are dentiform or conoidal, with their bases placed laterally and apices nearly meeting in the centre or median line; but as they do not actually meet, there is a longitudinal line of a plain semi-transparent appearance. The apertures are oval, inclining to a triangular forn, armed with two long slender divaricated spines on the distal margin. These differ from the spinous appearances refered to by Dr. Johnston as being produced by the incipient formation of the nest celis; they are long slender hair like appendages which stand prominently from the cells. They, are however rarely to be seen, but in the younger cells, for they are so delicate that the agitation of the sea alone is sufficient to destroy them, and hence they are never found in specimens dredged $a p$, but only in those carefully collected and preserved.

L. INNOMINATA. Encrusting, cells oval, in circular rows; sides of the cells with short transverse calcareous bands. Pl. xxii., fig. 4.

Hab. On stones, rare. Goran, Mr. Peach. Polperro. Mount's bay.

Calcareous, encrusting in patches of about half-an-inch in diameter. The cells are oval, but somewhat contracted at each extremity and inflated about the middle. The sides of the cells, from the intercellular spaces, are marked by short conoidal transverse bands; they are calcareous and extend for about one-fourth of the transverse diameter; the central and longitudinal half is therefore plain, and is also semitransparent. The apertures are circular, contracted, and 


\section{5}

shortly tubular. The margin is surronnded by numerous long and slender bristles, which are very commonly destroyed on all but the distal rim, and very frequently are wholly destroyed, from being so brittle; they may however grenerally be noticed as fragnentary tubercles. This species approaches very closely to the L. nitida especially when the bristles are destroyed. It differs however from that species, in having the transverse bands so short as to extend only onefourth of the diameter, in having the aperture circular and surrounded with bristles and having the cells contracted at each extremity.

LEPRALIA COCCINEA. Encrusting, calcareous; cells oval, rough, with a blunt process near the proximal lip of the aperture.

Lepralia coccinea, Johṇston's Brit. Zooph., p. 278.

Hab. On rocks near low water mark. Talland sand bay : Combe Lansallos; Polperro; Goran; Falmouth; Mouni's bay.

This generally occur's in circular encrusting patches of about one inch in dianseter, but it sometimes corers a space of, an inch and three-quarters. It somewhat varies in colour according to the locality in which it grows; it is most commonly of a yellowish brown, or brownish flesh colour, fading occasionally to a white. The cells are oval, and arranged in circular rows. Their surface is rough, granular or frosted, which is more apparent in dried than in living specimens. The aperture is oval, plain, with a denticle near the proximal margin. As the cells lie on the crust in close approximation and the apertures and denticles give it a waved appearance, the surface being granular, the line of demarcation between the cells is very obscure, hence the whole seems indistinct and confused.

L. TRIDENTATA. Encrusting, calcarcous; cells oval, lorizontal, rough; apertures oval, with a triangular denticle on the proximal, and one on each of the lateral rims. Pl. xxii. fig. 5.

Mab. On rocks, stones, Sc., from decp water to low water mark. Common.

This calcarcous and encrusting species varies from one quarter to one inch in diameter. In living specimens it is generally of a yellowish red colour inclining to a purple, but it is sonetimes of a delicate flesh colvur, all of which slightly fade in death. The cells are oral, horizontal, and closely arranged in circular rows: they are rather indistinet at first sinht from their frosted sterfaces, lacir irregularity or waved appearance about the aprelures, und their being somewhat 


\section{6}

imbedded. The surface is frosted or minutely punctured. The apertures are oval, and armed with three triangular denticles, which slightly lean over the opening; at the distal margin there are three or four long slender bristles, which readily break off. In the newer portions these bristles are nearly always to be found, and the mouth is terminal and almost Lid from view by the teeth and prominent character of the surrounding parts.

This most nearly approaches the $I$. coccinea in character, but differs so much as to show a specific difference.

L. VARIOLOSA. Encrusting, calcareous ; cells oval, alternate, or semi-alternate, punctured or frosted; separated from each other by a raised line. Pl. xxii., 6 .

Lepralia variolosa, Johnston's Brit. Zooph., p. 278, pl. 34, fig. 4.

Hab. On shells and stones, not uncommon. Polperro, Goran, Mr. Peach.

Encrusting; the crust is very closely adherent, circumscribed, and calcareous. It is of a yellowish flesh colour while living, which in death changes to a sallow white, or yellowish brown, but is very frequently of a pure white. The cells are oval, somewhat imbedded, long and slightly inflated; their surfaces are minutely punctured or frosted. They are separated from each other by a raised intercellular ridge, which is marked by large depressions. The apertures are round, but are liable to a little irregularity on the proximal lip; and on the distal margin are two long slender diverging spines, which in dried specimens, are most commonly destroyed.

L. VINCA. Calcareous, encrusting; cells ovoid, apertures round, armed, with three or more spines; the fissures between the cells marked with two rows of punctures, with bands of smaller ones embracing the cells. Pl. xxii,, fig. 7.

Hab. On stones at low water mark; common. Meragissey bay. Polperro.

This species very nearly resembles the Lepralia variolnsa, in almost every particular. Mr. Peach first pointed out to me, what he thought to be specific diflerences, and after examining a great variety of specimens, I am inclined to adopt his view. The chief differences between the two, are, that this is somewhat smaller, and whiter; the punctures between the cclls larger and more raised; and the cells appear as if bound down with chains from being surrounded by bands of minute cells. 


\section{7}

L. FENESTRALIS. Eucrusting, calcareous; cells urceolate, slightly immersed, semi-erect, and reticulated; aperture contracted, circular, with a slight tooth on tho proximal lip. Pl. xxii, fig. 8.

Hab. On stones at short distances from the shore, not uncommon.

This rarely exceeds three fourths of an inch in diameter: it is calcareous and encrusting. The cells are urceolate and closely arranged in circular rows; they do not, like most other species, lie horizontal to the crust, but the oral portions are elevated, or semi-erect. The surface of the cells is rough; several calcareous lines run longitudiually their whole length, and these are crossed nearly at right angles by shorter bands, which give the surface a network appearance with square meshes. This window-like surface, has the interspaces filled with a transparent membrane, which is more apparent in dried, than in living specimens. The aperture is small, contracted, and circular, with an irregularity on the proximal lip.

L. RETICULATA. Encrusting, calcareous; cells urceolate, reticulated; apertures semi-circular. Pl. xxii., fig. 9.

Hab. On stones \&c., not uncommon. Polperro, Lansallos bay; Goran, Mr. Peach.

This species encrusts the surfaces of stones, about low water mark, in patches varying to an inch and half in diameter. The cells are urceolate and nearly horizontal and, though not heaped together, have no constant order of arrangement. The cells are rough. From the aperture down the centre of the cell lines diverge obliquely downwards and outwards to the sides of the cells; these are again crossed by lines in an irregular manner; hence the surface lias a reticulated appearance. The interspaces or depressions formed by these lines are trauslucent. The lines, Lowever, are not alike in all the cells; but there is alway's an approach to the abore description, which may therefore be taken as a type of the whole. The apertures are semi-circular or half-moon shaped, large, with a raised rim, which is most apparent in dried specimens.

'This differs from L. fenestralis in several particulars; the cells are larger and more horizontal; the reticulations of no regular form, being sometimes square and at others rhomboidal. The lines forming the reticulations diverge from is median line, instead of running longitudinally as in $L$. fenestralis; in this the aperture is large and semi-circular, in tho other contracted and round. 
2. CILIATA. Encrusting; cells inflated, slightly rough; apertures ronad, contracted, armed with about six bristles on the distal and lateral margins. Pl. xxii., fig. 10.

Berenicea utriculata, Flening's Brit. An., y. 533. ILepralia ciliata, Johnston's Brit. Zooph., p. 279, pl. 34, fig. 6.

Hab. On stones and shells, from near low water mark to deep water. Whitsand bay, Polperro, Goran, \&c.

This species is membranu-calcareous, encrusting, thin, white, and spreading in a circular manner from about one inch to one and half inch in diameter. The cells are distant, or not in contact, ovato-globose and semi-erect. The apertures are terminal, contracted and armed with from five to seven tecth or spines on the distal and lateral margins. These spines from their brittleness, are commonly distroyed in preserved specimens, and most have but their mutilated remains.

L. TRISPINOSA. Encrusting; cells oval, closely arranged; surface roughish; apertures terminal, armed with three long conoidal spines on the distal margins.

Lepralia Trispinosa, Johnston's Brit. Zooph., p. 280, pl. 34, fig. 5.

HIab. On stones and shells from deep water, rare. Polperro.

Encrusting, thin membrano-calcareous, and white but freckled with yellow. The cells are elongated and oval, and horizontal and radiating. The apertures are raised, ovoid, with a notch on the prosimal, and armed with three long conical spines on the distal lip.

L. IMMERSA. Encrusting; cells oval, immersed; apertures oval, with a tooth on the proximal and from five to seven spines on the distal lip.

Berenicea immersa, Fleming's Brit. An, p.533. L. immersa, Johnston's Brit. Zooph., p. 280. Pl. zxxiv., fig. 8.

Hab. On stones a few miles from the shore. Polperro.

This is encrusting, irregular, and much thicker then $\mathbf{L}$. ciliata, which it somewhat resembles. It is rough, or minutely granular, and of a yellowish amber colour. The cells are ovato-globose, and immersed; the apertures are nearly circular, but slightly transversely ovoid, armed with a blunt tooth on the proximal and several spines on the distal lip. The spines are brittle and consequently are frequently destroyed or injured.

MEMBRANIPORA.

Gencric Characier: Polypidom encrusting, membranocalcareous, spreading irregularly, formed of a single layer 


\section{9}

of alternating approximated cells; cells oval, horizontal, inembranous; the apertures patulous, with hard calcareous rims. Polypes ascidian.

HAIRY SEA-MAT. M. Pilosa. Aperture of the cells oval, armed with horizontal teeth pointing towards the centre, and with one long bristle on the proximal margin.

Flustra pilosa, Ellis and Solander's Zooph., p. 13. Ir regular spongy foliaceous coralline, Ellis' Coral., p. 73, pl. 31. F. pilosa, Turton's Lin., vol. 4, p. 663. Stewart's Elem., vol. 2, p. 436. Fleming's Brit. An.. p. 537. Templeton in Mag. Nat. Hist., vol. 9, p. 469. Johnston's Brit. Zooph., p. 280 , pl. 34.

There is a variety of this species, in which the long bristle is either not formed, or destroyed, and is described by the following authors as a distinct species.

Ellis Coral., pl. 29, fig. D. Flustra dentata, Ellis and Solander's Zooph., p. 15. Turton's Lin., vol. 4. p, 63. Stewart's Elem., vol. 2, p. 436. Templeton in May. Nat. Hist., vol. 9, p. 469.

Hab. On stones, shells, and especially fuci about low water mark; abundant.

This is found under a great variety of appearances, depending on the nature and form of the substance on which it grows. It is encrusting; the cells are oril, slightly tubular, membrano-calcareous with thickened rimis. 'The apertures which are oval, are guarded by horizontal teeth pointing towards the centre. In the most perfect specimens, there is a long slender bristle on the proxinal lip; this however is sometimes absent, but there is generally a sufficicnt remnant to show its previous existence. As it grows on the minute fuci about low water mark, the cells are trequently invisible from the length and prominency of these bristles; hence the polypidoms look very hairy. The absence of tho bristle is generally found in specimens which grow on the fronds of the larger fuci. This has given rise to the sapposition that there are two species; but there are generally sufficient traces left behind to prove their destruction. As the larger sea-weeds are liable to continued, and frequently violent motion, the delicate and friable appendages are easily destroyed; whereas on the smaller fuci, which are stiff and allow of but of little motion, these parts are generally in a state of perfection. Specinens are sometimes found which are very dissimilar in appearance, and in fact look like distinct species, but after examining numerous specimens, no distinctive differences can be detected between them, and gradations can be traced into each other, so that for the present they must be consided as one species. 
It is generally encrusting, but sometimes it rises into frond-like prolongations, with a layer of cells on either side, separated from each other by a central cavity; the sides however are generally in contact, and afford each other mutual support.

M. UNICORNIS. Encrusting, calcareous; cells oval, with a short stout spine on the lateral or distal rim.

Flustra unicornis, Fleming's Brit. An., p. 536.

Hab. On stones, not uncommon. Polperro. Goran, \&c.

This encrusting calcareous species occurs in patches of about three-fourths of an inch in diameter. The cells are oval, with stout calcareous rims, and are arranged in circular rows. The margins of the oral apertures, are embossed and marked with three or four circular orifices. The apertures are circular and armed with a stout spine on the distal or lateral margins.

M. PEACHII. Encrusting; cells radiating; apertures oval, unarmed, with two punctures at each extremity.

Flustra Peachii, 9th Report of the Cornwall Polytechnic Society, p. 81.

Hab. On dead muscle and oyster shells in the Falmouth and Fowey rivers; off the Deadman point; common.

Encrusting, membrano-calcareous; cells ovoid, having their longest diameter in the axis of growth, and at each extremity two minute punctures; the apertures even and unarmed. The cells which have a radiating distribution, appear somewhat confused from their radiating from so many points and intermingling with each other.

This species was first found by Mr. Peach in the Fowey river; since then in company with him I have found it abundantly encrusting almost every shell dredged up, from Mixtow to the mouth of the river. I have since found it in deep water nine leagues south of the Deadman and in many other parts of the British Channel. It is now acknowledged to be a good species and I therefore give it the name of its discoverer.

ESCHARID AE.

Polypidoms calcareous, or membrano-calcareous, very variable in form; composed of cells usually disposed in quincunx; the cells oblong, pentagonal or hexagonal, conjunct, immersed, horizontal to the plane of axis, with subterminal or lateral apertures, which are usually covered with opercula. Polypes ascidian. 


\section{1}

FLUSTRA. Linnæus.

Generic Character: Polypidom plant-like, membranaceons, flexile, frondose, or crustaceous; formed of cells arranged quincuncially, in several series, in one or two layers; cells in juxta-position, more or less quadrangular, flat, with distinct borders; the apertures transverse, semi-lunar, valvular, subterminal.

\section{* Foliaceous, cells on both sides.}

BROAD LEAVED SEA-MAT. F. Foliacea. Flat, branched; branches palmate, truncated; cells in longitudinal rows, alternate, arched at the distal, narrow at the proximal extremity, armed with four or five marginal denticles.

Fucus telam lineam sericeamive textura sua xmulans, Raii Synop., p. 42. Flustra foliacea, Ellis and Solander's Zoopb., p. 12, pl. 2, fig. 8. Broad leaved Horn Wrack, Ellis' Cor., p. 70, pl. 29, no. 2, figs. a A, C, Flustra foliacea, Turton's Lin., vol. 4, p. 663; Templeton in Mag. Nat. Hist., vol. 9, p. 469. Fleming's Brit. An., p. 535. Johnston's Brit. Zooph., p. 283, figs. 1, 2. Stewart's Elem., vol. 2, p. 435.

Hab. On stones from deep water. Whitsand, Tallandsand, and Mevagissey bays, Goran; common, frequently washed on shore.

This species grows to the height of four inches, in flat, palmated tufts, and is one of the most elegant of all the sea mats; when living it is of a lively flesh colour, which, in deatl, turns to a dusky white. At the base, it is rounded and narrow, but soon gets expanded and flat as it ascends. The branches are broadly palmate and truncated. Cells on both sides, from the base to the apex, contracted below, above rounded and dilated, with two pair of teeth on the external rim, which are shorter than the diameter of the cell. It frequently emits an odour resembling that of violets after a shower.

PAPER SEA-MAT. F. Charlacea. Cells quadrangular, bulging about the middle; apertures unarmed.

Ellis' Coral., p. 38, figs. 8, o. P. Flustra papyracea, Ellis and Solander's Zooph., p. 13. Fleming's Brit. An., p. 535, no. 140. F. chartacea, 'Turton's Lin., vol, 4, p. 663. Stewart's Elem., vol. 2, p. 436. Johnston's Brit. Zooph., p. 284.

Hab. On a shell from deep water, eight leagues south of the Deadnan; very rare. 
This delicate species grows to the height of one third of an inch, and is of a light straw colour; the cells are on both sides, running from the base to the apez, are quadrangular in form, but enlarged about the centres. It is dichotomously branched, and the terminations of the branches are axesluaped, or truncated.

Fleming seems to be in doubt, whether to consider this as a distinct species, or a variety of the preceding; be founds his doubts on a specimen sent him by Montagu; but the specimens I have seen do not countenance such a doulit. It much more resembles the Flustra truncata; from which there appears to be no sure mark of distiction.

\section{* Foliaceous, with cells on one side only.}

FAN SHAPED SEA-MAT. F. Avicularis. Cells quadrangular, in three or four rows, with a spine at each distal angle on the external edge, and one on each side below, pointing across the cells.

Ellis' Coral., pl. 38, fig. \%. Flustra avicularis, Fleming's Brit. An., p. 536, no. 141. Crisia flustroides, Lamouroux's Cor. Flex., p. 141. JuLuston's Brit. Zooph., p. 286, pl. 36, figs. 3, 4.

$H a b$. On stones, shells, especially the Pinna ingens and Pecten maximus, on the back of the larger spider crabs, from deep water; common.

This very beautiful and delicate species varies in height to one inch, it is however sometimes so small as not to exceed one fifth of an inch; when living it is of a very delicate flesh colour, but in dying it changes to a dull brown.

The polypidom is compressed, thin and divided dicho. tomously into flat segments which terminate in a truncated manner; when living it is very elastic, but when dead it is so friable that it falls to pieces on the slightest handling. The cells are on one surface only of the polypidom, the other being plain or marked only by the attachments of the bases of the cells. They are quadrangular in form, and are arranged into from three to five alternate rows. The superior and external margins have a single stout spine, one on each angle, between which rises a pearly globular operculum. Inferiorly to these are two other spines, which pass transversely across the diameter of the cell, reaching nearly about the middle. On the external margins of the cells there is frequently to be observed, a very curious and remarkable appendage in the shape of a bird's bead. When the specinen is living this organ is continually employed in opening and closing its bill; but of what service it is to the 
creature is at present unknown. The similarity between the cells of this species and the Cellulariu avicularia is so very great, that many naturalists have consilered them the youn? and adult state of the same species; and for this, or some other reason, Dr. Fleming in his "British Animals" ranks tlicm as one; he refers his $F$. avicularis to the Crisia avicularia and C. fustroides of Lamouroux; and the Sertularia avicularia of Linnaus; this cannot now lowever, be maintained. As the cells in $C$. avicularia are only in two alternate rows, while the Flustra avicularis has abont four or five, the cellularia is supposed to be the youngest state. In answer to this, it may be observed, that the Flustra avicularis has been obtained only one fourth of an inch in laeight, yet having the four and five rows of cells; while the Cellularia avicularia luas not been found so small, but almost always higher than the Flustra, and sometimes one third as high again with only two rows of cells; and they have not yet been found in company with each other. In addition to this, the Flustra is common, while the other is comparatively rare; and in death the Flustra changes to a brown, while the other fades to a dull white; so that there can be no doubt of their being distinct. This opinion is also entertained by Jolunston, Milne Edwards, and Mr. Bean.

\section{* * Crustaceous}

CHAGRIN SEA-MAT. F. Membranacea. Encrusting; cells quadrangular, alternate, with a blunt spine at each angle.

Flnstra nembranacca, Ellis and Solander's Zooph., p. 18, no. 12. Turlon's Lin., vol. 4, p. 66.5. Fleming's Brit. An., p. 5:36. Stewart's Elem., vol. 2, p. 437. Johnston's Brit. Zoopli., p. 287, pl. 38, fig. 1, 2, 3.

Ilab. On sea weed, (Laminaria digitata) every where common. Pl. xxi.

This abundant species, encrusts the broad fronds of the larer sea weed, in spots varying from a mrere speck to two or three fect in length. It has a very delicate and ganzr-like appearance, and while lying exposed on the shore looks more like a thin saline incrustation, than a liviner being. On examination even with the naked eye, it will be fonnd to be composed of quadrangular cells, with a blunt horn on each angle. The longest diameter of the cell is in the axis of growth, and the rims only are calcareously white; the other portions being white and translncent. On the upper or distal part of the cell, and but a very short distance trom the two spines, is a small semi-lunar opening, conrex ahore and 


\section{4}

concave below, through which the polype protrudes. The cells are arranged in alternate rows, and are about three times as long as they are wide. About December, January, and February, numerous yellow semi-translucent sacs protrude irregularly from all parts of the surface, which are filled with a gelatinous fluid, which afterwards becomes granular. On examination they appear to rise from the sides of the cells, and make their external appearance through the polype mouths, and finally grow to nearly twice the length of the cells. The production of these sacs, is the destruction of the polypes of the cells in which they grow. The polype is active, with twelve ciliated tentacula in a single circle.

F. LINEATA. Encrusting; cells oval, radiating from a centre; apertures armed with numerous horizontal teeth pointing towards the centre.

Flustra lineata, Turton's Lin., vol. 4, p. 665. Johnston's Brit. Zooph., p. 288, pl. 28, fig. 4.

Hab. On stones in pools between tide marks, common. Polperro, Whitsand bay. Goran. Fowey, \&c.

This encrusting species, appears to be enceloped in doubt and obscurity. It occurs in patches of about one inch diameter, but most frequently about one half or three-fourths of an inch. The cells are oval, in justaposition and very small. The apertures are armed with numerous slight horizontal teeth which meet about the centre; sometimes the teeth on one side are very greatly developed, while those of the other are nearly abortive; but in all cases from the presence of these teeth, the cells are hardly to be distinguished by the naked eye. On the distal margin are two long diverging spines.

Sereral gentlemen well acquainted with this department of Natural History, have expressed a doubt as to the character of this species; but though they have considered it as an abnormal condition of some other species, they have not even named the one to which they suppose it to belong. After many exaninations of many specimens, I cannot discover the reason for this opinion. However, to ascertain the probability of such a deviation, I have procured specimens from twenty-five localities, differing from each other, and Mr. Peach has procured me several others, from Groran and the neighbourhood, and a few have been procured fiom the coast of Devonshire, all of which possess the same characters, which if abnormal is very renarkable. 1 believe it to be as good a species as any other in the list, though it seems not to be the Flustra lineata of Johnston's work. 


\section{5}

F. CARNOSA. Enerusting; fleshy, with inbedded remote cells; apertures eontraeted and armed.

Flustra hispida, Fleming's Brit. An., p. 537. Flustra carnosa, Johnston's Brit. Zooph., p. 283, pl. 37, fig. 5.

Hab. On Fuci, common.

It is a thick, fleshy enerusting species, of a light brown or cream colour. The cells are iubedded, distant from each other, with contracted wrinkled apertures of a half-moonshape, and three or four erect spinous teeth.

F. TUBERCULATA. Encrusting, calcareous, thin; cells oval, with a tuberele on the distal, and one on each lateral margin.

Flustra tuberculata, Jolinston's Brit. Zooph., p. 239, pl. 34 , fig. 9.

Hab. On stones a few miles from the shore. Polperro. Groran. Mount's bay.

This is not a rare species, but is to be found encrusting stones at short distances from the shore, from the entrance of Plymouth sound to Falmouth harbour and Monnt's bay. In a living state it is so much unlike the figures and descriptions given of it, that at one time I considered it a new species, and it was by an examination of the dried specimens only that the mistake was discovered. In a living state, its encrusting eharacter resembles the Flustra membranacea, being thin and gauze-like; but it encrusts stones instead of sea weed. It is most commonly found in cirenmscribed patehes varying from a quarter to one inch in diameter. The eells are alternate with stout calcareous rins, and are oval, inelining to a quadrangular or luzenge-shape. At each angle is a large stout tubercle, without any spine or process. It is of a deep fiesh red colour. As the cells are alternate, wih a tubercle on the distal margin, each appears to be surrounded with four, which slightly encroach on the quadrangular diameter. These tubercles are always of a brighter colour than any other part.

When the specimen is dried, this appearance is considerably altered; the quadrangular shape of the cells is charged into an oval; the tubercte on the distal margin appears to be considerably abore the cell and to stand on a loullow dome; and on each side is a curved process. 'This species assumes a great variety of forms, from the appearance of this tuberele. In old specimens it is so much injured, and eometimes so entirely destroyed, that it is difficult to recognize it; in these slates Dr. Johnston's figures represcut it. 
CELLULARIA.

Generic Character: Polypidom caleareons or membranos ealcareons, confervoid, divided sub-dichotomously, the divisions narrow, composed of two alternating series of oblong sessile cells on a single plane; the apertures terminal, oblique, facing one way and usually covered with an operculum. Polypes ascidian.

CILIATED CORALLINE. C. Ciliata. White, erect, dichotomously branched; cells distinctly alternate, all opening on one side; apertures oblique, with four or five long bristles on the upper and outer margins. Pl. xxiii, fig. 1.

Ciliated Coralline, Ellis' Coral., p. 38, pl. 20, fig. d D. Sertularia ciliata, Turton's Lin., vol. 4, p. 685. Stewart's Elem., vol. 2, p. 448. Cellularia ciliata, Flem. Brit. Ano, p. 540. Cellaria ciliata, Ellis and Solander's Zooph,, p. 24, no. 6. Crisia siliata, Lamouroux's Cor. Flex., p. 139, Templeton in Mag. Nat. Hist., vol. 9, p. 468. Cellularia ciliata, Johnston's Brit. Zooph., p. 290, pl. 38, fig. I and 2.

Hab. On Corallines and sponges, near the Eddystone lighthouse; not common. Mount's bay.

This minute and delicate species grows in down-like tufts to the height of half-an-inch. It is white, calcareous, and dichotomously branched. The cells are distinctly alternate, narrow at the base, and enlarged above; the apertures are all furned on one side, and are very large, oblique, with four or five bollow spines, which, when perfect, are about four times as long as the diameter of the cell; these are situated at the upper and outer lahial rim. Over the apertures are helmetshaped pearly lids, which are raised in drying.

CREEPING S'TONY CORALLINE. C. Scruposa. Creeping, dichotomously branched; cells in a double series, alternate; apertures round, unarnied, with a stout angle at the superior and external margin. P!. xxiii., fig. 2 .

Creeping Stony Coralline, Ellis' Coral., po 38, no. 4, pl. 20, fig. c C. Sertularia scruposa, Turton's Lin., vol. 4, p. 685. Stewart's Elem., vol. 2, p. 448 . C. Scruposa, Fleming's Brit. An., p. 539. Cellaria scruposa, Ellis and Solander's Zooph., p. 23, no. 5. Crisia scruposa, Lamouroux's Cur. Flex., p. 139. Templeton in Mag. Nat. Hist, vol. 9, p. 469. Cellularia scruposa, Johnston's Brit. Zooph., p. 291, pl. 38, fig. 5 and 6. Bellamy's South Devon, p. 270.

Hab. On the roots of sea weed, on Corallines, and on the back of the Corwich crab. Whitsand bay. Looe. Polperro. Lantivet bay. Fowey. Goran. Port Loe. Mount's bay. 


\section{7}

This, compared with the last is a stout species. It is abundantly found towards autumn among the matted roots of the larger fuci; in fliese siluations it grows in great profusion so as to fill up every crevice. It is ealcareous, white, and sometimes tinged with red, and rarely exceeds one inch in height, being more inclined to spread than rise. As it thus trails along, many of the branches eome in eontact with the substance on which it grows, from these points long slender tendrils arise, which firmly clasp the fuci and secure the polypidom in its situation. The cells are in the branches and do not stand prominently out as in the last species; they are alternate, and open by oval oblique apertures which have a stout blunt spine on the upper and outer rim. 'The apertures all face on one plane, and the lower portion of one orifice is immediately above the upper margin of another.

CREEPING CORALLINE. C. Reptans. Calcarcous, creeping, dichotomously branched; cells semi-alternate, with oblique apertures, armed with four or live spines at their outer rims. Pl. xxiii, fig. 3.

Creeping Coralline, Ellis' Coral., p. 37, pl. 20, fig. b B. Sertularia reptans, Turton's Lin., vol. 4, p. 685. Stewart's Elenı, vol. 2, p. 448. Cellularia reptans, Fleming's Brit. An., p. 540. Johnston's Brit. Zooph., p. 291, pl. 38, figs. 3 and 4. Bellamy's South Devon, p. 270. Crisia reptans, Templeton in Mag. Nat. Hist., vol.9, p. 469. Lamouroux's Cor. Flex., p. 140.

Ilab. On the roots of the larger fuci, every where comiuon.

This species is very similar to the last in its habits and spreading character. It is calcareous, spreading and grows to the height of about three quarters of an inch. It is dichotomously branched; and the branches are linear and diverging. The cells are biserial, alternate, and very loosely arranged; the apertures are oval, oblique, divergent, and have at their superior and external rim several long tubular spines. These spines, however are much shorter than those of $C$. ciliata, rarely exceeding in length the diameter of the cell. 'The number of these appendiges varies in different specimens; Ellis has figured it as having only two, a number I have also seen, but lhey most commonly amount to three or four and very rarcly indeed to five; but whether two, three or four, the same number generally pervades the whole specimen. At the joints, where they comes in conact with the substanco on which the polypidom grows, a few slender tendrils arise, wilh looks, by which the animal is firmly rooted. 
BIRD'S.HEAD CORALLINE. C. Avicularia. Calcareous, erect, dichotomously branched; cells glandular, opening on one plane, with an erect spine at each superior angle, and the rudiments of two others below, crossing the diameter.

Bird's-head Coralline, Ellis's Coral., p. 36, pl. 20, fig. a A. Sertularia avicularia, Turton's Lin., vol. 4, p. 685. Stewart's Elem., vol. 2, p. 448. Cellaria avicularia, Ellis and Solander's Zooph., p. 22. Crisia avicularia, Lamouroux's Cor. Flex., p. 141. Templeton in Mag. Nat. Hist., vol. 9, p. 468. Cellularia avicularia, Johnston's Brit. Zooph., p. 292, pl. 36, fig. 78.

Hab. On the back of the Corwich crab; at low water mark. Mevagissey bay. Mount's bay.

This beautiful and delicate coralline is by no means common; compared with the others of this genus, it is more bushy, erect, and graceful. It is calcareous, erect, dichotomously branched, and varies in height from one inch, to one and three quarters. When living it is very elastic and of a delicate flesh colour; but when dead, it is white and brittle. It is rooted by matted tubular fibres, and it arises by a small round stem, which soon begins to divide and branch. The branches are formed of two rows of alternating cells which open on one plane. The cells are quadrangular and have a spine at each superior angle which point upwards; below these are two others, one on each side, which cross the diameter of the cell; these last are sometimes abseut or in so rudimentary a state as scarcely to be noted. The apertures, like those of Flustra, are subterminal and transrerse, and are covered with pearly shield-like opercula, which become elevated between the superior spines in dying. On the external edges of the cells, there are frequentiy appendages, resembling birds heads, to be seen, which move to and from with the regularity of a pendulum, at the same time they open and shut their bills like a bird. This species has been considered the young state of Flustra avicularis by sone authors, but from this I dissent, and the reasons for which are briefly noticed under Flustra avicularis.

CELLULARIA PLUMOSA. Confervoid; cells biserial, alternate, opening on one plane; apertures irregularly elliptical, with a stout spine on the outer and upper margin. Pl. sxiii., fig. 4.

Corallina pumila erecta ramosior, Raii, Synop., rol, 1, p. 37, pl, 2, fig.1. Soft Feathered Coralline, Ellis' Coral., p. 33, pl. 18, tig. a A. Sertularia fastigiata, Turton's Lin., vol. 4, p. 684. Stewart's Elem., rol. 2, p. 448 . Cellularia 
fastigiata, Blumenbach's Man., p. 273. Flening's Brit. An., p. 539. Cellaria plumosa, Ellis and S'lander's Zooph., p. 21. Crisia fastigiata, 'T'empleton in Mag. Nat. Hist., vol. 9, p.468. A camarchis pluinosa, Julnoston's Brit. 'Zuopil., p. 294, pl. 39.

Hab. At short distances from the shore, on rocky.ground. Polperro, rare. Falmouth, Miss Warren.

This confervoid species attains the height of four inches, but is more commonly found about two and half or three. It is calcareous, of a delicate tlesh colour, fading in death to white, and is dichotomously branched. The branches are slender, and composed of two rows of alternating cells, all opering on the same surface. The cells are oblong, diaphanous, like porcelain, polished, with a spine on the upper and outer angle. The ovaries are pear-shuped and situated over the apertures. This species is liable to so much disfiguration that it is not easy at all tines to cietect it. I have procured many specimens in such a state that it was found imipossible to decide on their specific characters; and it was not till the examination of a tolerably perfect specimen shown me by Miss Warren, of Flushing, that the specitic characters were identified. In old specimens the cells become obsoleto and the branches deformed and stunted.

Dr. Johnston has arranged it as Acamarclis instead of Cellularia, but as the characters hare a great degree of saneness in description as well as figure it is here united with Cellularia. To the experienced naturalist, however. there will appear characters which approach to Filustra, but nut more so than in C. avicularia, and both are here united in one genus.

\section{FARCIMIA.}

Generic Character: Polypidom rooted, plant-like, calcareous, dichotonious; the branches cylindrical, regularly jointed, with immersed rhomboidal cells direrging from the axis, disposed in quincunx, and opening on the surface; the aperturcs lateral, plain, non-operculate.

FARCIMIA SALICORNIA. Branches composed of ono cylindrical articulation, jointed ouly at their origins and terminations; surrounded with lozenge shaped cells. Pl. xx., fig. 3 .

Corallina fistulosa fragilis, Raii, Hist., rol. 1, p. 65. Bugle Coralline, Ellis' Coral., p. 46, pl. 23. 'Tubularia hstulosa, 'Turton's Lin., vol. 4, p. 666 . Stewat's Elem., vol. 2? p. 438. Cellularia farciminoides, Ellis and Sulander s Zooph., p. 26. Farcimia fistulosa, Fleming's Brit. Au, p. 534. Salicornia fistulosa, Templeton in Mar. Nat. Hist., vol. 9, p. 469. 
Hab. On stones and shells from Eddystone Lighthouse to the Lizard and Land's-end, common.

This elegant and beautiful species varies in height from one to six inches, and is readily recognized from having no British species like it. It is arborescent and dichotomously branched; the branches are cylindrical and contracted at their terminations, and two ramifications arise from each joint. The cells are numerous, rhomboidal in shape, plain, quincuncially arranged on all parts of the branches. It is rooted by tubular fibres, and the branches are erecto-patent, and from the contracted terminations of the internodes being said to resemble sausages it derives its generic name Farcimia. A good deal of difference occurs in the size of the polypidom, and the shape and distribution of the cells, in different specimens. In some now before me, the branches are three fourths of an inch in length and very stout, about a line in transverse diameter; in others the branches are about one fourth of an inch long and about as stout as an ordinary sewing needle, and some are fusiform and others are club-shaped. The cells also are liable to considerable $v$ ariations, not only in different specimens, but in different parts of the same. Thus those cells at the inferior portion of the branches are quadrangular most commonly, while at the upper parts the superior angle is expanded into an arch, and hence resembles the cells of Flustra foliacea. It would almost seem as if there were two species confounded under this name; but although they differ so much in size I have been unable to discover any specific distinctions between them. The cells can offer no guide in determining this point as they vary so much in the same specimen. This is a very elegant species both as it regards its arborescent form, and the delicately embossed appearance of its branches.

RETEPORA. Lamark.

Generic Character: Coral foliaceous, stony, fragile, netted; cells opening one way, on the upper or inner side, short and not prominent. Polypes ascidian.

NETTED CORAL. R. Reticulata. Polypidom latticed, wavy and convolute, the upper surface warty and porous. Millepora retepora, Borlase's Cornwall, p. 240, pl. 24, fig. 8. Millepora reticulata, Ellis and Solander's Zooph., p. 138. Retepora reticulata, Fleming's Brit. An., p. 531. Jolnston's Brit. Zooph., p. 296.

Hab. Two leagues south-west of Gillstone, Scilly, Rev. W. Borlase.

Of this species, I liare been unable to procure a Cornish specimen. Borlase found it at Scilly and I have specimens 
from Sark, so that, though rare it will probably be found throughout the English channel.

\section{ESCHARA、Ray.}

Generic Character: Polypilom nembrano-calcareous; inflexible, brittle, expanding in the form of foliaccous porous lamella, variously folded and anastamosing, and consisting of two layers of opposite cells: cells immersed, coalesent, horizontal to the plane of axis; opening on both surfaces in quincuncial pores protected with an operculum. Pulypes ascidian.

STONY FOLIACEOUS CORALLINE. E. Foliacea. Membrano-calcareous, in thin wared plates like the borders of a lady's cap; plates frequently uniting; cells on both sides of the folds.

Stony Foliaceous Coralline, Ellis' Coral., p. 71, no. 3, pl. 30, fig. a A B C. Borlase, p. 239, pl. 24, fig. 6. Eschara retiformis, Raii, Synop., vol. 1, p. 31. Fleming's Brit. An., p. 531. Millepora foliacea, Ellis and Solander's Zuoph,, p. 133. Turton's Lin.. vol. 4, p.636. Miliepora fascialis, Stewart's Elem., vol. 2, p. 427. Eschara foliacea, Johnston's Brit. Zooph., p. 297, pl. 40.

Hab. About two miles N. N. W. of the Eddystone, very common. Off the Deadman point occasionally; mid-channel, common. Falmouth bay, Miss Vigurs.

This is the largest of all the Cornish, and probably of the British corals. Dr. Johnston says it "attains a large size being often three or four inclies ligh and from twelve to twenty in its greatest diameter." But this, eren, is small compared with many specimens procured on the Cornish coast; the largest I ever saw was hooked up by a fisherman off the Eddlystone in the Autmmn of 1843, it measured seren feet four inches in circumference, and a foot and three quarters in deptb. It is, however, most commonly found in a unch lumbler form. When living it is of a delicate flesh coluur which turns to a light browu in death. It is a very thin ard foliaccous species, resembling a sheet of paper waved into various folds. The plaits or folds frequently unite and form cavernous passages through the mass. 'The cells are small, and arranged on both surfaces of the sheet; on the older portions they are recognized by the small rouvd apertures quincuncially arranged: the surfaces being made even by calcarcous deposit. When living it is slighuly elastic, but when dead it is exceedingly britte; breaking on tho least touch. Beside this foliaceous or plated furm, there is another, not noticed by authors; an eucrusting form which resembles the Filustra bullata of Linnasus. 'This is found 
encrusting stones and forming its cells like a Flustra, in large circumscribed patches. The first appearance of its rising into a lamellated form, is the production of detached ridges and papillary eminences, as these become more elevated they assume the form described above.

The growth of the cells appear to be periodic and rapid; formed, in the first place very delicately, and afterwards completed and strengthened by depositions of calcareons matter. In almost every specimen, bands of this periodic growth are to be seen varying from half-an-inch to one inch in depth. If these bands be carefully examined it will bo found, that all the cells composing them are nearly in the same condition of growth; each band differing from the other. Hence the polypidom is frequently marked by ridges, which indicate the extent of the various enlargements; and the whole process of the growth of the cells, from the mere gelatinous effusion, to the complete obliteration, can be observed in a single specimen.

The form of the cells varies with the form of the polypidom, yet every change can be considered but as variations of one form from mechanical causes. When the extension takes place in the encrusting form, the effusion of the pulp is more extensire than in the erect and foliaceous state. In this, lime is rapidly deposited and the cells appear larger and not so much crowded as in the other kind, so that the growth is effected here as it is in Lepralia, F/ustra, \&c. The cells, which are superficial and on both sides of the leaf when erect, stand on a solid base which unites both surfaces. They present three varieties of appearance the first of which is the semi-gelatinous or pulpy state, the second where the surface is granular, from the fully developed cells, and the third is the confused appearance produced by the partial and complete obliteration of the cells.

\section{ALCYONIDCL $\mathbb{E}$.}

Polypidoms sponge-like, fleshy, polymorphous; the cells irregular in disposition, immersed, and concealed with a contractile non-operculate aperture.

\section{ALCYONIDIUM.}

Generic Characler: "Polypidom fleshy, lobed, or crustaceous; cells immersed, pentagonal, with fibro-corneous parietes, the aperture terminal, simple, contractile. Polypes ascidian."

SEA RAGGED STAFF. (A. Gelatinusum.) Polypidom fleshy, cylindrical, slightly compressed, irregularly branched or lobed, smooth.

Fucus Spongiosus nodosus, Raii Synop., vol 1, p. 49, no. 42. Alcyonium, seu fucus nodosus et spongiosus, Ellis' 


\section{3}

Cor., p. 87, no. 5, pl. 32, fig. d D. Alcyonium gelatinosum, Ellis and Solander's Zoopl., p. 176. Turton's Lin., vol. 4, p. 653. Fleming's Brit. An., p. 517. Lamouron's Cor. Flex., p. 350. Stewart's Elem., vol. 2, p. 432. Johnston's Brit. Zooph., p. 300, pl. 41, figs. 1-3.

Hab. On shells and stones from deep water; not rare on the south and south-west coast.

This species varies in height to sixteen inches, and is said sometimes to grow as high ås "several feet; " in its texture it is spongy or fleshy, semi-opaque, dotted, and of an amber colour, varying from the light yellow, to the brown tint; the surface is even, smooth, polished, lobulated, and dotted; the polypes lie bereath the surface in the substance of tho polypictom, with which they are rery intimately connected. The tentacula, though of very unequal length, are long, ciliated, capable of being folled up, and so withdrawn into the cell; in the carliest state of growth, it is a simple incrustation, but soon assumes a finger-like prolongation, from which lobes afterwards sprout on all sides.

This was considered a vegetable hy the older botanists; Ray thought it a Fucus; Ellis appears to be among tho first to have discovered its true character.

A. HIRSU'TUM. Polypidom flesby, simple or lobed, compressed, surface granuiar.

A. hirsutum, Fleming's Brit. An., p. 517. Johnston's Brit. Zooph., p. 303, pl. 42, ligs. 1, 2.

Hab. On fuci about low water mark, and on a Pinna ingens from deep water. Polperro, Tallandsand bay, Meragissey bay.

All the specimens of this species which I have found in the Cornish seas, were long, slender, very much compressed, semi-transparent, and lleshy, with a slightly granular surface, clouded with brown, and marked with black specks; but it is said to be sometimes sub..ey lindrical and palmate. It is soft and flexible. Its structure is cellular, the cells delicate and compactly arranged. The granulations of the surfaco are formed by minute conoidal papilla, which are closily crowded together. The tentacula vary in number from sixteen to eighteen.

A. SUBVIRIDE. R. Q. C. Massive, lobulated, of a brownish green colour; surface irregular, cosered with small pores, interspersed with larger ones of very irregular shape.

Hab. From deep water, off the Deadman point.

When recent and living, it is senerally of a greenish orange, but is sometimes of an olivo bruwa or grees colour, 
with a shining polished surface; it is filled with a gelatinous slime and covered with minute punctures. The polypo orifices are large, distant, and of very irregular shape. The polypes, though seen, in consequence of other engagements were not examined till they had become too much injured for description. It varies in height to ten inches, and in thickness to six. This I have failed to identify with any species described by the authors to whom I have access, and in fact is now held to be new.

A. ECHINATUM. Encrusting, thin; surface granular when living, roughened with papille when dead.

A. echinatum, Fleming's Brit. An., p. 517. Johnston's Brit. Zooph., p. 304, pl. 42., fig. 3, 4.

Hab. On dead specimens of the Buccinum undatum, and other dead univalve shells; common. Polperro, Mevagissey, Goran, and Whitsand bay.

This species is invariably found encrusting dead univalve shells, it is very thin, and of a brown colour. When living it is fleshy, slightly diaphanous, and the months of the cells are but slightly prominent; when dry, it beconies hard, shrivelled, and the apertures of the cells prominent and stiff. The points or prickles, which are distributed over the surface, have no permanent regularity, sometimes being arranged in rows, as Dr. Johnston has figured them, and at others distributed in a very irregular manner.

Montagu first discovered it as a zoophyte, on the Devon. shire coast, and communicated it to Fleming; he says the polypes have twelve tertacula.

A. PARASITICUM. Parasitical on corallines, arenaceous; cells distant, round, or substance pornus.

A. parasiticum, Fleming's Brit. An., p. 518. Johnston's Brit. Zooph., p. 304, pl. 11, figs, 4, 5.

Dr. Fleming first placed this among the zoophytes, but was apparently undecided to what genus it belonged, not having an opportunity of examining it in a living state. It is found encrusting the stems of the Sertulariada, as S. abictina, and polyzonias, $\mathbb{P}$ lumularia falcata, \&c. In appearance it is sandy, porous, and is about the tenth of an inch in thickness. The cells externally, appear as minute distinct tubes, which perforate the substance throughout. The poly pidom, in fact, instead of being secreted or formed by the animal as a part of its own character, as the polypidoms of all the others, is formed of fine sand and mud, cemented together by a glairy substance, as is observed in many worms, as in the sabella, \&c. $;$ the whole appearance so closely appruaches to what is obsersed in worms, that I am inclined to think it the work of 
an annulated animal, rather than that of a zoophyte, though I have not succeeded in detecting it.

\section{LIMNIADES.}

Polypidoms fleshy, or spongy, or corneous, polymorphous; the polypes placed in tubes with angular or round orifices, closed when the animals recedc.

\section{FREDERICELLA.}

Generic Character: Polypidom fixed, coriaceous, tubular, branched. Polypes issuing from the extremities of the branches; tentacular disc orbicular, tentacula arranged on the margin of the disc in a single series, about twenty four in number, invested at their origin by a membrane. Dr. Allman, Ann. and Mag. Nat. Hist., vol. 13, p. 331.

FREDERICELLA SULTANA. Horny, trailing, sparingly branched; branches tubular, slosed at their terminations when the polype is withdrawn.

Plumatella sultana, Johnston's Brit. Zooph., p. 323.

Hab. On the weeds in the ponds at Trengwainton, near Penzance; common.

This species till very lately, was arranged with Plumatella, but that genus is now divided into two, Plumatella, and Fredericella by Allman and others.

It is horny, tubular, creeping, and rarely exceeds an inch in length. The bravcles are few in number, short and sometimes dichotomously diriding. When the animal is withdrawn, the openings of the tubes are closed. When the animal protrudes itself, the openings become patulous. The tentacula are about thirty, long, slender, though not of equal length, and ciliated. The inferior third of tentacula and external surface of the mouth cloated with long cilia which point towards the termination of tentacula, these do not move in a vibratory manner, but are sometimes closely applied to the surface and at others hang loosely. The gizzard and intestine very risible. 
The following species of Hydra, was discovered too late to be inserted in its proper place at page 11 .

\section{HYDRAID E.}

Polypes gemmiparous, the young pullulating from the body of the parent.

\section{HYDRA.}

Generic Character: Polypes locomotive, single, naked, gelatinous, sub-cylindrical, but very contractile and mutable in form, the mouth encircled with a single series of granulous filiforma tentacula.

COMMON HYDRA. Hydra Vulgaris. Body gelatinous, sub-cylindrical; tentacula seven to twelve, as long or longer than the body.

Hydra vulgaris, Ellis and Solander's Zonph., p. 9. Turton's Lin., vol. 4, p. 672. Stewart's Elem., vol. 2, p. 452. Templeton in Mag. Nat. Hist., vol.9, p. 418. Johnston's Brit. Zooph., p. 95, pl. 1.

Hab. In the Trengwainton ponds, near Penzance. Common.

This, though a rare species in the country is common in all parts of the ponds; where it is to be found on Nitella translucens and other weeds growing there. If the usual des. criptions of this Hydra are characteristic of its appearance, it would seem as if the one now under consideration was a distinct species. As, howerer the Hydræ are liable to great variations both in form and colour the present one has been refered to the $H$. vulgaris, as it bears the closest resemblance to it. It appears to be the variety b. grisea, Johnsion; but though the tentacula are longer than the body, yet they are of a claret red and not olive green colour. The body is red, gelatinous, and ovoid; the tentacula vary in number from seven to twelve are long and granular, but vary in length and size according to the degree of their contraction. This is one of the creatures on which Trembly performed his celebrated experimemts. His conclusions have been verified by subsequent observers. Their powers of supporting life under the most violent injuries are all but miraculous, and more nearly resemble the attributes of Milton's Angels, than any reality,

Vital in every part, not as frail as man

In entrails, heart, or head, liver or veins,

Cannot but by annihilating die;

Nor in their liquid texture mortal wound

Receive, no more than can the fluid air. 
CORALLINADAE.

The productions embraced by this division of our subject, the "Articulated calcareous Corallines of Ellis," are essen. tially distinct from those previously described. In the foregoing Orders the presence of a polype has been deemed an indispensable requisite to their admission among Znophytes; here howcver, after many examinations of the different species in their natural states, at different seasons of the year, and under a great diversity of weather, no polype has ever yet been discovered; consequently the calling of those productions Zoophytes is an error, as the arraniement now stands. Though destitute of polypes or any signs of animal life, many Authors still consider them in the light of animal existences; while others as zealonsly contend that they belong to the regetable kingdom. In the early age of Natural History, these as well as the polypous zoopliytes were considered vegetables. Ray speaking of the productions now under consideration, says "Corallina est plantæ genus in aquis nascens, tenuissime divisum ex partibus constans articulatione quadam veluti conjunctis." This opinion was combated by Ellis, and from his superior knowledge he orerthrew the reasonings of his opponents, though he failed in establishing their animal character as firmly as he had done that of the others. His views, however were generally receired as correct, and Linnæus, who knew Ellis and in tho study of zoophytes seems to have been his follower, though at first an adrocate for the vegetable nature of all zoophytes, yet embraced the doctrine of the animal character of the polypous species and eventually of these calcareous corallines. He says; "Corallinas ad Regnum Animale pertinere ex substantia earum calcarea constat, cum umnen calcem Animalium esso productum verrissimum sit." 'There never was any pretension to the discovery of a polype; hence its aninal character depends on its calcareous strueture. Cuvier's opinion appears to have been similar to that of Ellis, since he classes the articulated Corallines with Crisia, Acamarchis, Farcimia, and Flustra, between which there is not the least similarity except in the calcareous siructure. Lamouroux also includes them in his work on Corallines: he says, however that he never saw tho polypes, though ho supposes the animal to be diffused in the form of retractile filaments ; this is however purely ideal. In the Millepora polymorpha such a supposition might seem to receivo a confirmation from a cursory observer, since it is not at all 


\section{8}

uncommon to find long slender ciliated tendrils protruding in pairs from different parts of its surface. On examination, however, these are found to belong to a minute and beautiful worm,* and which forms its tubes in the crevices or fissures, and sometimes on the surface. It would not be safe however to make the presence or absence of a polype an essential qualification for the animal or vegetahle kingdoms. By so doing the Clustering Polype of Ellis and the sponges would be included among vegetables; the former of which and most of the latter are I think undoubtedly animal. From all that I have observed of them I am inclined to think they are situated on the vegetable side of the line which may supposed to divide the two kingdoms.

Though they are given up by Zoologists, yet the Botanist will not receive them, and thus they may be said to hover between the two kingloms. Mr. Harvey has not included them in his manual of British Algæ, and Professor Graham, according to Dr. Johnston, says : "Let Zoologists keep their cryptogamia, the vegetable kingdom has more than enough." As, however, they are few in number, and have been classed among the zoophytes by many systematists they are here added as a supplement to the foregoing genera.

In character they are encrusting, or arborescent, calcareous; articulated or massive; the surface in a recent state covered with minute pores, which disappear in drying: no polype.

JANIA.

Generic Character: Arborescent, jointed; the joints cylindrical, dichotomously branclied; the branches filiform.

REDDISH HAIR-LIKE CORALLINE. Jania Rubens. (VAR. A.) Calcareous, jointed, arborescent; lower joints simple, cylindrical, about four times as long as thick, nearly of equal thickness throughout: branches commonly terminating in bifid extremities, sometimes knobular.

Reddish Hair-like Coralline, Ellis' Coral., p. 50, no. 5, pl. 24, fig. e E. Corallina rubens, Turton's Lin., vol. 4, p. 672. Stewart's Elem., vol. 2, p. 439. Ellis and Solander's Zooph., p. 123, no. 28. Jania rubens, Fleming's Brit. An., p. 514. Templeton in Mag. Nat. Hist., vol.9, p. 469. Lamouroux's Cor. Flex., p. 272. Bellamy's Nat. Hist., South Devon, p. 267. Johnston's Brit. Cor., p. 224, pl. 22.

This delicate coralline is abundantly found on almost all our beaches, of a white colour, from being washed on shore, and alternately being covered with the sea, and again left to the influence of the sun. When living, it is eitber of a red

* Leucodore Ciliatus. 


\section{9}

colour or pale green. It grows in tufts on rocks, or stems of fuci, in deep water ; it is dichotomously branched, and tho branches are filiform and spreading. The joints are long, slender, and cylindrical, of equal thickness throughout, or but slightly enlarged at tho upper extremity. The two following species are considered to be rarieties of this, by Fleming, Lamouroux and Jolınston.

COCK'S-COMB CORALLINE. Jania Rubens, (VAR. B.) Dichotomously branched, the upper part of the last joint but one very much enlarged; the upper part of the lower joint less so.

Crested or Cock's-comb Coralline, Ellis' Coral., p. 51, no. 7, pl. 24, fig. f F. Corallina cristata, Turton's Lin,, vol. 4, p. 672. Stewart's Elem., vol. 2, p. 440. Ellis and Solander's Zooph., p. 121. Jania rubens, var. B, Fleming's Brit. An., p. 514. Lamouroux's Cor. Flex., var. 'C. (Cristata.)

\section{Hab. Common on fuci on all our shores.}

The chief differences between this and the last are, that the internodes are shorter and stouter, being about two and a half times as long as they are thick; the superior extremities of the joints are more enlarged, especially the last joint but one; and from the joints being shorter, and two branches arising from every joint, it is also stouter, and more bushy than the last.

It is also liable to great variations of colour, but is generally either red or green; but when washed ashore it is generally bleached.

SEED-BEARING CORALLINE. Jania Rubens, (var.c.)

Dichotomously branched; the joints swollen, but the terminal ones most so.

Seed-Bearing Coralline, Ellis' Coral., p. 51, no. 8, tal. 21, flg. g G. Corallina spermophoros, Turton's Lin, vol. 4, p. 672, Stewart's Elem., vol. 2, p. 410. Ellis and SoJander's Zooplı., p. 122. Jania rubens, var. D. Lamouroux's ('or. Flex. Fleming's Brit. An., p. 5lt. Templeton in Mag. Nat. Hist., rol.9, p. 169.

Hab. On fuci, common. Polperro, Lantiret bay.

This approaclies very nearly the Var. B. in cluaracter, but the branches are more loosely agregated, more spreading, and rarely found in such tufts.

These two last are, I think, moloutedly varicties of each other, and the figures of Lamouroux at jul. 9, firs. (i and 7 , are very characteristic. 
HORNED CORALLINE. Jania Corniculata. Arbó. rescent. dichotomously branched; the upper part of each joint horned.

White Slender Jointed Coralline, Ellis' Coral., p. 50, pl. 24, fig. d D. Corallina corniculata, Turton's Lin., vol. 4, p. 672. Stewart's Elem., vol. 2, p. 440. Ellis and Solander's Zooph., p. 121, no. 25. Jania corniculata, Fleming's Brit. An.. p. 514. Lamouroux's Cor. Flex., p. 274. Bellamy's Nat. Hist. of S. Devon, p. 267.

Hab. On fuci. Lantivet, Tallandsand, and Mevagissey bays; common.

Of a delicate pea green colour, which soon bleaches to white, from exposure on the beach. This is the stoutest of all the dichotomously branching corallines found on our coast. It is readily recognized, by the joints being somewhat compressed, and above being prolonged on each sido into a horn.

\section{CORALLINA.}

Generic Character ; Arborescent, jointed; the joints slightly compressed, trichotomously branched.

From this Genus being trichotomously branched, the appearance of a primary stem is preserved, and the two other branches, appear to rise from the sides.

COMMON CORALLINE. C. Officinalis. Arborescent, jointed; joints somewhat wedge-shaperl with truncated angles; lateral offshoots short, their internodes short and obtuse.

Coralline of the shops, Corallina Anglica, Corallina alba Officinarum, Ellis' Coral., p. 48, pl. 24, fig. a A. Corallina officinalis, 'Turton's Lin., vol. 4, p. 671. Stewart's Elem., vol. 2, p. 439. Fleming's Brit. An., p. 514. Ellis' and Solander's Zooph., p. 118. Templeton in Mag. Nat. Hist., vol.9. p 469. Bellamy's Nat, Hist, of South Devon, p. $26 \%$. Lanouroux's Cor. Flex., p. 283. Johnston's Brit. Coral., p. 217, pl. 22.

Hab. Abundant in pools between high and low water mark.

It is generally of a light brick brown colour, or yellowish, and is said to be occasionally green.

SLENDER TRAILING CORALLINE. C. Elongata. Arborescent, slender, jointed, trichotomously branclied; the internodes nearly as thick as they are long.

Slender 'Trailing Coralline, Ellis' Coral., p. 48, pl. 24, fig. no. 3. Corallina elongata, Turton's Lin., vol. 4, p. 671. 
Stewart's Elem., vol. 2, p. 439. Lamouroux's Cur. Flex.. p. 235. Ellis and Solander's Zooph., p. 119.

Hab. In deeper water than the last, but sometimes mixed with it in deep pools.

This coralline very much resembles the last, of which it appears to be only a variety. It grows to a greater length, is more slender, and more branched and the branches more fliform than the C. officinalis, and is prostrate instead of being semi-erect.

C. SQUAMATA. Calcareous, jointed, trichotomously branched, joints compressed, two edged.

Upright English Coralline, with spear-like heads and flat joints, Ellis' Coral., p. 49, pl. 24, fir. c C. Corallina squamata, Ellis and Solander's 'Zooph., p. 117. Turton's Lin., vol. 4, p. 671. Stewart's Elem., vol. 2, p. 439. Lamouroux's ('or. Flex., p. 287. Fleming's Brit. An, p. $51 j$. Jolinston's Brit. Coral., p. 222.

This delicate species is most commonly of a delicate peagreen colour. It resembles the $C$. officinalis in general appearance, but is undoubtedly distinct from it. 'The internodes are wider in proportion to their length and more compressed than in that species. The branches are erectopatent, joints linear, pointed and compressed at the edges. The compression of the edges is a character which is always present.

\section{MILLEPORA.}

Generic Character: Calcareous ; form irregular, encrusting, with semi-circular plates; rising in knobular protruberances, or in kneed branches.

LIVERWORT MILLEPORA. N. Lichcnoides, Calcareous, encrusting, with horizontal semi-circular plates which turn up at their edges, pulished.

Corallium Cretaceun Lichenoiles, Ellis' Coral., p. 76. Millepora lichenoides, Ellis and Solander's Zooph., p. 131, pl. 2:3, figs. 10, 1:2. Fleming's Brit. An., p. 528, no. 117. Bellamy's Nat. Hist. of South Deron, p. 269. Borlase's Nat. Hist. of Cornwall, p. 23:9, pl. 24, figs. 2, j. Millepora Alga, Turton's Lin., rol. 4, p. 6:39. Stewart's Lilem., vul. 2, p. 428.

Hab. On the common coralline, in pools; rery common.

When recent it is of a redilish brown colour, paler towards the edges. It encrusts the stems of the common coralline, of which it is thoucht to be a rariety, and semels off horizontal semi-circular plates, which are turned up at their edges. When recent, it will be found markod by 
minute pores on the upper surface. These disappear in drying, and the colour changes to a very pale brown.

BRITISH CORAL. M. Polymorpha. Calcareous, encrusting, rising either in globular heads or kneed branches.

Corallium pumilum album, fere lapideum ramosum, et Corallium album pumilum nostras, R. S., Ellis' Coral., p. 76, pl. 27, no. 1,C. Millepora polymorpha, Ellis and Solander's Zooph., p. 130. Turton's Lin., vol. 4, p. 638. Fleming's Brit. An., p. 528. Stewart's Elem., vol. 2, p. 426, Bellamy's Nat. Hist. of South Devon, p. 269. Sprig or branchy Coral, Borlase's Nat. Hist. of Cornwall, p. 239, pl. 24, figs. 4 and 5 .

Hab. On rocks from the Rame Head to Falmouth; abundant in the Falmouth mud.

On the rocks, it is found enerusting, and rising into globular heads sometimes singly, and at others congregated like a bunch of grapes. In the Falmouth mud it occurs as kneed branches in abundance; from the time of the Naturalist Ray, to the present time, a period of about 150 years, it has been used, in that neighbourhood, as a manure without much apparent decrease of the supply. Its virtues as a manure are increased, either by burning, or beating to a coarse. powder. 


\section{SUPPLEMENT}

To the Two yfirst Burtions

OF THE

\section{ORNISH FAUNA,}

By JONATIIAN COUCH, F.L.S., Sंc.

It is desirable that as each successive portion of this comm pendium of the Natural History of the County is produced to the public, a record shall be made in it of such species of the families treated of in the former parts, as may have been discovered since their publication; or where they are already known, but as of rare occurrence, that such additional information shall be giren as may lead to a more extended knowledge of them. Something like this has been already attempted at the end of the second part; where the new discoveries are enumerated in a report which was originally read before the section on Natural History of the British Association for Science, when it assembled at Plymouth in the year 1841. Our additions at this time therefore must be regarded in the light of a second supplement; and in adding it to that which there is reason to regard as being the last that will probably appear in any close connection with the enquiries of the anthor of the two former, he will employ the occasion now presented to him, to express the pleasure he feels in knowing that observers of nature in the lield and flood, have within a few yedrs so greatly increased, as well in ability and accuracy, as in numbers. He ean well call to mind a time when that ind:vidual was thought to be possessed with some great singhlarity of taste, who could be prompted in rain or sumshiate, fair or stormy weather, to wander among the recesses of the shore, to search out and examine the strangoly formed creatures of Grod in their native haunts. Thtsere was no kindred spirit to hail his suceess, nor any accossible perio. dical throngh which to pour out his pleasure of discovery, and increase it by communication to tho equally solntary 


\section{4}

labourers in the same field, thinly scattered through the land. These were the times when a Lady of rank and fortune was subjected to an accusation of insanity, for which the principal proof advanced was, that she had made a collection of Butterflies.

But a wiser and more kindly spirit has prevailed; and those who neither know nor care to know the works of skill and beauty which their Creator did not disdain to make, are yet at least found to respect the study; and the number of those who observe and labour is greatly increased. It is from the latter circumstance that so many additions are continually making to the catalogue of known, and especially of our native animals. Gentlemen are found who will show so much respect to the Naturalist or a Public Institution, as to preserve for them such rare specimens as may fall in their way; and we are consequently less accustomed to hear of the occurrence of rare or unknown Birds and Fishes, that have been wondered at, and thrown aside.

\section{THE WHALE TRIBE. CETACEANS.}

BLACK OR LEADING WHALE. Delphinus melas. Flening's British Animals, p. 34. Phocæna melas, Bell's British Quadrupeds, p. 483. Delphinus deductor, Scoresby's History of the Arctic Regions.

A specimen of this Whale was taken on the 29th of March, 1842, on Looe Island; and another in the following year, on the mainland nearly opposite the same place. Of the former I had an opportunity of making a sketch, and minute exanination: which were published in the Annals of Natural History, vol. 9, p. 371, pl. 6. It was there remarhed that there could be no question of its being the species relerred to in the British works named above; and consequently that it was the Delphinus of Trail, D. globiceps of Cuvier, and Globicephalus deductor of Jardine; but whilst the descriptions giren by these naturalists are suffi. ciently minute and accurate to decide the species, they in common with the accompanying tigures have the misfortune to fail in sone important particulars, which may lead to error if it shall be found that a nearly allied species exists. The figure in $\mathrm{Mr}$. Bell's work is confessedly taken from Cuvier; and though I have had no opportunity of consulting the "Ann. du Museum," in which the paper of the great French Naturalist is contained, or the work on Cetaceans by his brotier, yet I think it fair to conclude that it is correctly copied. The singularity of position, however, given to the tail, as thrown up orer the back, and the attenuated 
form assigned to the figure both of Scoreshy and Bell (though most obvious in the latter) lead to a suspicion that the latter is indebted for its existence to the former, and consequently that the engraving of Dr. 'Trail, whom Scoresby has followed, is the only undoubted original.

The following notes, which were made when comparing the figures of Bell and Scoresby (whose description at least is from Trail) with the animal lying farourably before me, will point out the differences. In Mr. Bell's work, the bulk is much $t 00$ slender, especially on the anterior portion, and not enough compressed posteriorly, nor sufficiently ridged on that part, above and below. The caudal fin is 100 much divided and attenuated at the sides; for though a single specimen might chance to die in the attitude given, nothing short of an error in the outline could represent the corner of the tail so long and slender. The forehead also is not sufficiently prominent and globular: the teeth are too numerus and conspicuous; the under jaw too much projecting. Jenyns represents the teeth conical and sharp, but in this specimen their points were blunt. The pectoral fin is not well represented in the figures; and the dorsal is placed too far behind, its exact possition being, as far as the eye can judge, just above the centre of gravity. The lengih of this animal, measured along the curve, was twenty two and half feet; and the quantity of oil produced from it seventy gallons.

Remains of Hakes (Gadus merlucius) were tound in the stomach of the second specimen.

\section{FALCONS.}

GYRFALCON. Falco Islandicus. Jenyn s Manual, p. 27. Gyrtalco candicans, Fleming's British Animals, p. 51. Falco gyrfalco, Bewick's British Birds, vol. 1. Yarrell's British Birds, vol. 1, p. 26.

This Bird has hitherto occupied a place in the catalogue of the Coruish Fama on the authority of a single specimen recorded by Burlase, Another instance of its occurrence is now to be added, on the authority of E. H. Rodd, Leq. in whose beautiful collection at Penzance the specinen is preserved.

ASHCOLOURED HARRIER. Buteo cincraceus. Fleming's Br. An., p. 5j. Jenyn's Man., p. 80. Bewitk's Br. B., vol. 1. Circus Montagui, Yarrell's Br. B., rul. I, p. 100 .

In a communication to the Royal Institution of Cornwall in 1810. (Report, p. 76.) Mr. liodd has expressed his 


\section{6}

opinion that the specimen in the Museum at Truro supposed to represent this species, is erroneously marked; but he announces the possession of two specinens, a male and female, killed in Cornwall, and in his own collection.

GREAT BUSTARD. Otis tarda. Turton's Lin., rol. 1, p. 436. Bewick's Br. B., vol. 1, p. 314. - Fleming's Brit., An., p. 115. Jenyns' Man. p. 174. Yarrell's Br. B., vol. 2, p. 362.

A specimen was shot on Goonhilly Downs, early in February, 1843; and it is now in the collection of E. H. Rodd, Esq. at Penzance. Of course it was a straggler from some eastward portion of the kingdom; and we may be permitted to regret that the rarity and value of the bird should deprive it of the chance of being propogated in a situation so well adapted for its residence.

RED LEGGED PARTRIDGE. Tetrao rufus. Tarton's

Lin., vol. 1, p. 456. Bewick's Br. B., vol. 1. sup. p. 39. Perdix rufa, Fleming's Brit. An., p. $45 . \quad$. rubra, Jenyns' Man., p, 172. Yarrell's Br. B., vol. 2, p. 343.

About the middle of September, 1842, a specimen of this bird was shot in the parish of Lanreath, and was sent to Mr. C. Jackson of East Looe, to be preserved.

\section{SYLVIAD AE. WARBLERS.}

GARDEN WARBLER. Curruca hortensis. Fleming's Br. An., p. 70. Sylvia H., Bewick's Br, B., vol. 1. Jenyns' Man., p. 108. Yarrell's Br. B., vol. 1, p. 285.

Mr. Rodd has added this species to the catalogue of Cornish birds; but its destribution seems to be local. It is found at Trebartha.

BLACK START. Sylvia Tithys. Jenyns' Man. p. 105. Phænicura T. Yarrell's Br. B., vol. 1, p. 241.

Within my own knowledge a female was killed, January 6th, 1842, after a smart frost; and a male bird was killed near Penzance, also in the wister. The capture of both the Red and Black Start is rare in Cornwall; and the specinens which have occurred have for the most part been in the winter. In one instance however, the former has been known to breed in the county: at Trebartha Hall.

SNOWFLAKE. Emberiza nivaiis. Turton's Lin., vol. 1, p. 530. E. montana, E. glacialis, of authors. E. mustelina, Bewick's Br. B., vol. 1, p. 181, 184. Fleming's Brit. An., p. 78. Jenyns' Man., p, 129. Yarrell's 13r. B., vol. $1, \mathrm{p} .425$, 


\section{7}

It has been shot near Penzance, and I believe at othor places in the county

\section{ANTHID AE. PIPPETS.}

RICHARD'S PIPPET. Anthus Richardi. Fleming's Brit.

An., p. 75. Jenyns' Man., p. 117. A. Richardi, Yarrell's Br. B., vol. 1, p. 398.

This species of Lark has been usually regarded as rare; and it is not many years since $I$ was present at a meeting of the Zoological Club of the Linnean Society when the first known specimen was produced for examination. But it is probably less rare than has been supposed; since four specimens were secured at one shot, in a field close to Penzance. It was noted that in their habits they were tame and void of suspicion.

\section{HIRUNDINID AE. SWALLOWS.}

\section{ALPINE SWIFT. Cypselus alpinus. Jenyns' Man.,} p. 159. Yarrell's Br. B., vol. 2, p. 239.

In the first part of the Cornish Fauna the occurrence of this bird was noted, with something like the expression of uncertainty. But it is now rendered clear by the capture of a specimen, which flew on board of a vessel, about the middle of June, 1842, at about 40 miles west of the Land's end, and it was so fatigued as to be easily tak $\mathrm{cn}$.

\section{SCOLOPACIDAE. WOODCOCKS.}

PECTORAL SANDPIPER. Tringa pectoralis. Jenyns'

Man., p. 210. Yarrell's Br. B., vol. 2, p. 654.

An account of the specimen of this rare bird that was shot in the Scilly Islands, is given in the Report of the Royal Institution of Cornwall, in 1840, by E. H. Rodd, Esq., and further particulars of the same specimen are contained in Mr. Yarrell's work, from D. W. Mitchell, Esq., by whom the bird was shot. Another individual escaped.

WOODCOCK. Scolopax rusticola. Turton's Lin., rol. 1.

Fleming's Brit. An., p. 105. Jenyns' Man., p. 204.

Yarrell's Br. B., rol. 2. p. 583.

The instances in which this bird has been known to pass the summer with us, are rare; and in Borlase's Natural History of the county is the only anthentic record of thus discovery of its nest. But in the first weck in June, 1843, a young Woodcock was sent 10 Mr. C. Jackson, fur preserration, that was found on the public road near Budmin, and when discovered it was scarcely dead. $A \mathrm{~s}$ it was not of age for distant flight, it was judged to have been diopped where found, by the parents; which hare been supposed 10 
be in the habit of carrying their young to their feeding places, before they have acquired suficient strength to convey themselves.

COMMON BITTERN. Ardea stellaris. Turton's Lin., vol, 1. Fleming's Brit. An., p. 9j. Jenyns' Maz., p. 190. Yarrell's Br. B., vol. 2, p. 475.

There is no need to record this bird for its rarity; but it seems to abound much more in the west than in the eastern part of the County. But it is here inserted to notice its foor. I am assured that in one instance a Red Wing, (Turdus Iliacus) and in another a Rail, (Gallinula Crex) was found in its stomach.

SPOONBILL. Platalea leucorodia. Jenyns'Man., p. 193. Yarrell's Br. B., vol. 2, p. 499.

In the third week of October, 18t3, nineteen of these birds were seen on the north coast of the county, near Newquay, and four of them killed: of which I examined a specimen. In the previous year, one was shot on the Goonhilly downs, and it is believed that these are not the only instances in which it has been taken.

A hen bird shot at Tregenbris in Newlyn is in the Museum, haring been presented by Mr. Robarts.

\section{ALCAD $/$ E.}

RINGED GUILLEMOT. Uria lacrymans. Yarrell's Br. B., vol. 3, p. 351 .

Since this bird has been judged a separate species from Uria Troile, it has been found to be as common as the latter.

\section{LARID $\mathbb{A}$.}

ARCTIC TERN. SEA SWALLOW. MIRET. Sterna Arctica. Flening's Brit. An, p. 144. Jenyns' Man., p. 26\%. Yarrell's Br. B., vol. 3, p. 298.

Mr. Yarrell has related the visit of an immense number of these birds along the west coast of the Kingdom, from the Bristol Channel to various parts of Wales, and even to the inland towns of the neighbourhood, in the month of May, 1842; but the account given in the History of British birds does not include the full extent of their destribution, nor of their numbers; which seem to have been as if all tho Terns in existence had agreed to come upon the British shores. There were multitudes along the coasts and harbours of the north and south of Cornwall and Deron. Of six shot at one time, at Looe, five were males. 
CHELONIADAE. TURTLES.

CORIACEOUS TURTLE. Testudo coriacea. Turton's Lin., vol. I. Coriudo cor. Fleming's Brit. An., p. 149. Sphargis cor. Jenyns' Man., p. 290. Bell's Br. Reptiles, p. 11.

The occurrence of any of the Turtles in the British seas is so rare, that it seems proper to note every instance of it; even where as in the instance presently to be given, an opportunity has not been afforded of examining the specimen. The following paragraph is extracted from the Falmouth Packet Newspaper, of the date of August 10, 1839. "Penzance. On Saturday last at about 7 o'clock in the evening, as the 'Trinity buoy yacht was coning into the bay from the Wolf Rock, something was observed about two miles from Penberth cove floating on the water, which appeared to be a boat, botton up. They bore away towards it, and discovered it to be an immense 'Turtle. They manned their boat and pursued it more than an hour, during which it dived and rose to the surface several times. They were within a boat's length of it twice, but it eluded all their attempts to take it. They report it as the largest they ever saw." The species of Turtle to which I have referred this announcement, was long since recorded by Borlase as taken in Cornwall; who mentions of one of near eight hundred weight. But there is a description of another species,-Chelonia caretta,-in the 4 th vol. N. S., of Loudon's Magazine of Natural History, p. 136, that was caught in January, 1840, at the mouth of the river Tor in Deronshire, and which weighed about two hundred pounds.

\section{SPARIDAE. SEA BREAMS.}

ORPH, COUCH'S SEA BREAM. Orphts Rondeletii. Pagellus Roudeletii, C. Zoologist, vol. 1, p. 81.

The Sparoid fishes are found to bear so considerable a resemblance to each other in form and colour, and until very recent times, have been so inadequately represented in figures, most of which have been taken from dried skins or prepared specimens, in which all the distinguishing marks of life, and separation from one another have been lost-that we necd not wonder if we occasionally find the synonyms unisapplied, the references to ancient anthors misplaced, and certain species rediscovered, that have a better title to a designation than ohers which for a time have been permitted to bear it. Another fertile source of error arises 
from the fact, common indeed to species of other families in nature, that several fishes bear different names in different places; and, still worse, in some instances the same name is applied by the same people to separate species: not from supposing them the sane, but from some characters which they possess in common, of which this name is descriptive, though in other respects the species widely differ. Many curions instances night be given in illustration of these remarks, but scarcely any one has led to a greater extent of confusion than this species; which appears to have been known to some ancient Naturalists, bui which hitherto does not seen to have fallen into the hands of any recent enquirer.

The specimen here described was taken November 8 th, 1842, with a baited look, at a place termed the Edges, a margin of rocky ground running parallel with the land at the distance of three miles south of Polperro. The weight was sis pounds: the body in figure and thickness not unlike that of the common Sea Bream (Pagellus centrodontus) but rather deeper and more stout. Tae hearl thick, the muzzle renarkably so, and rounded, the line of the front sloping suddenly from the forehead to the mouth; the eyes of moderate size, elevated, and near the front, iris yellow; nostrils in a slight depression, the superior large and $p a-$ tulous; jaws equal, in a line with the front, the lower with a well marked chin; the teeth in front rather stont, somewhat separate, those of the upper and lower jaws interlocking. The scales large, and conspicuous on the posterior plate of the gillcovers; the middle plate has none, and there are but few vestiges on the anterior plate. The heal being short, the back rises high above it. The lateral line rery dark, less curved than in the nore common Sparoill fishes, and scarcely continued full to the tail; the boly terminating in a defined form at the caudal fin, with an incision opposite the direction of the lateral line; it is also somewhat contracted at the vent. Colour of the front and summit of the head a brownish red; of the back and fins nuch like that of the Becker (Pagrus vulgaris), such as would be forned by a mixture of lake and vernillion; fins the same, except the anal, which is pale yellow; sides pale reci, belly whitish. As the colours faded, at the angles where the scales meet there was a yellow margin.

Fin rays: D. 12, 10 . P. 13. V. 4. A. 38. C.-

The third ray of the pectoral fin longest, the second and first regularly becomirg slsorter. The remarkable shortness of the head, the roundness and perpendicularity of the front, equality of the jaws, interlocking of the teeths, and singular 


\subsection{1}

chin, are sufficient to distinguish this species from any one hitherto recognized as British. At the same time it so nearly agrees with the figure and description of the Orpho of Rondeletius, that I hare little hesitation in believing it to

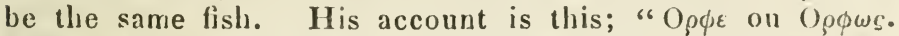
Les Latins ont rétenu ce nom horsmis Gaze du quel est appellé Cernua. Il est poisson marin de rivage, aucunement semblable an Parre rougeastre. Il ha les jenx grands, les dens qui entrent les unes entres les autres. De nombre, do situation dáelles, déguillons semblable au Pagre. Il ha le trou de excremens fort petit; car il ha seulement une petite fente laquela vous ne verres sans presser le ventre; il u'ha point de vaisseaux spermatiques, (certainly an error of the observer). 'Tel est noster orphe, an quel convient tout ceque Aristote è Atheneé ont attribué. En peu de tems il devient grand, il est mangechaire, solitaire, il ha des dens qui se serrent les unes entre les autres, il est cachè en hyver," p. 139, of the French edition.

It is intimated by Rondeletius that among the Greeks nore than one fish was known by the name of Orphus; and we further learn that the word, Cernua, by which some Latin writers have rendered the Greek Oopos has been applied to a still grealer number of species, all of them distinct from this, and even from the River Rud: the true Cernua of the Moderns. After stating this, Gesner, who copies the figure of Rondeletius, adds: nos (inquit Rondeletius) orphum hîc non depingimus eum, qui a Græecis quibust'am hodie vulgari lingua orplui nomine dicitur. Est enim nostro longe major, utpote qui pondere viginti libras æquet, wee sit litoralis. Sed orphum dipingimus ex Aristotle, Atheneo, Plinio. Is Piscis est litoralis magis quam pelagius, Pagro quodammodo similis colore ex purpureo rubescente, idea rubentem appellavit Ovidius; (verun haec apud Plinium ex Oridio non recte citatal eguntur.) Oridius pelagiun facit, Aristoteles vero AElianus lituralem. Oppiano degit in petris cavemosis, qua plena sunt chamis et patellis (quibus nimirum rescitur.) Graci hodie, ut dictum est alium Piscem rulgo orphum vel Rophum appellant; quem Bellonius orphum facit. Ray (Synopsis, p. 133,) who limits the name Orphus to the Rud, describes lie fish which he terms Orpheus vetermm, from Ronceletius, in a manner to show that he was altogether unacquainted with it; and as the species termed Orphus by Bellonius is the other and more common one known by this name among the Greeks, we need not wonder at finding Ruysch ('Theatrum Animalium, rol. 1, p. 24, ) resignimg all hope of extricatin! from such utter confusion what ho saw might still be at well defined species. Nor does it appear that eren the most 


\section{2}

industrious and attentive Naturalists of the present day have been more fortunate than their predecessors in obtaining a knowledge of this species. Risso makes no mention of it in his Ichthyologie de Nice; and Cuvier is equally ignorant of it, for his Pagrus Orphus is a very different fish, and he supposes the Orphe of Rondeletius, to which I have referred the fish now described, to be no other than our common Sea Bream: the Pagellus centrodontus of his own work. The Dorade Orphe of Risso is pronounced by Cuvier to be his own Pagellus Orphus. We see that it is represented by Rondeletius as solitary and rare, and by Oppian as only locally common; while even Pliny's remark, that it had only been described by Ovid, though erroneous in itself, yet leads to the inference that according to his information it was not often caught: these are circumstances which, taken together, will assist us in understanding the reasons of the doubts which bave hitherto hung over this species.

The specimen above referred to is deposited in the national collection in the British Museum.

\section{SHORT SEA BREAM. Pagellus curtus. C. Zoologist,} vol. 2, p. 393.

On the second of September 1843, a fisherman took with one of his ordinary baits a Sea Bream, which he presently. discerned to have never before fallen under his notice; and in consequence it was transferred to my possession as soon as he reached the land, which was before sufficient time had elapsed to allow it to undergo any change. Its length was one foot two inches, the greatest depth nine inches and a half, and, in proportion to the kindred species, it was of considerable thickness. The under jaw was slightly the longest, the teeth in front and forward on the sides slight, conical, and somewhat scattered; gape moderate. Eye very large, being one inch and three eighths across; nostrils in a depression before the eyes, in this respect and in the cheeks for the most part resembling the common Sea Bream, (Pagellus centrodontus) but slightly differing in the markings of the head. The body thick and plump; scales on the cheeks and body large, those on the hinder part of the body, especially above the lateral line, having well marked festooned edges; those on the anterior part less regularly so. Lateral line at first mounting, arched, sinking opposite the ending of the dorsal and anal fins, waved in its course, and mounting again as it approaches the caudal fin; at its origin a large black spot. Pectoral fins very long, reaching to within a short distance of the termination of the anal fin, being in length four inches and three quarters, and passing two inches beyond the vent. Commencement of the dorsal 


\section{3}

just above the origin of the rays of the pectoral. Tail lunated.
P. 15.
D. 12,12
V. 1,5 .
A. 3, 13.
C, ahout 20.

Colours much as in the common Sea Brean, but more virid; top of the head rich brown; the back scarlet red, lighter on the sides, the belly white, with slight mottlings. Dorsal, pectoral and caudal fins, and within the mouth, vermillion; ventral and anal fins paler. Compared with the common Sea Bream laid beside it, beside the remarkable difference in the dimensions, it is distinguished by a wider gape, by teeth less thickly placed, thongh resembling in arrangement and siructure, especially the incisors; by a less rounded muzzle, a much larger eye, and longer pectorals, which are also differently shaped, being more arched. In a common Sea Brcam of the sanne length these fins were three inches and three quarters long. The scales also were more decidedly waved at their edge. In the stomach I found a Comatula and the bait, a slice of fish, with which it was taken; but in the lower intestine were rather broad-pieces of brown sea-weed, covered with Flustræ, but this being undigested, seems not to be its ordinary food.

At the first glance I was led to suspect that this fish was nothing more than a dumpy specimen of the common Sea Bream; but it differed in so many particulars, beside the shortened form, that on minute examination I have been compelled to conclude that it is a separate species; in which opinion I an supported by the decision of an eminent Naturalist. I bave not bcen able to discover any species at all closely rescmbling it in the works of Rondeletius, Gesner, Ray, Linnæus, Gronovius, Risso or Cuvier; and am therefore compelled to conclude that it is now for the first time described: a circumstance the less to be wondered at, when we recollect that even in the linited waters of the Mediterranean, and so near a region also as Madeira, several fishes have been recorded of which ouly a single specimen has been obtained. The fish here described has been deposited with the next preceding, in the British Museum.

BOGUL. Boops primus, hay's Synopsis, p. 135. Box vulgaris, Cuvier; but in his plate Boops V. Spare bogue, Risso, Ichthyologic, p. 242.

A specimen of this fish, the first recorded as taken in Britain, was canght in a ground sean at St. Mawes, in tho early part of October, 1842; and coming into the possession of Alfred Fox, Esq., was hindly presented to the Museum at 'Truro. It is abundant in the diediterranean; but has rarely been taken out of it. 
SCOMBERID AE. MACKARELS.

PLAIN BONITO. Auxis valgaris, Cuvier who pronounces it to be Scomber bisus of Rafinesque, and $S$. rochei of Risso, Ichthyologic, p. 165. Yarrell's Brit. Fishes, 2nd. edition, vol. 1, p. 160.

By the older Naturalists this species was confounded with two or three others under the general name of Tunny. It is of such rare occurrence in the British seas as not to have been recorded in the first edition of Mr. Yarrell's work. Two specimens afterwards came into the possession of that Gentleman from Yarmouth. A third specimen was taken in a mackarel sean at Looe in June, 1843, and came into the hands of Mr. Clernent Jackson; to whom I am_indebted for a characteristic outline of its form.

A second Cornish specimen was taken near Penzance in a mackarel sean, in the beginning of July 1844 : and of it I received the following description, from Mr. Richard Quiller Couch, into whose hands it came. Length eighteen and a half inches, girth behind the first dorsal fin eleven and a half inches. Viewed laterally it has a resemblance to the mackarel, but is more plump, and the tail seems proportionally smaller. From the point of the lower jaw to the margin of the gillcovers four and a half inches: both jaws pointed; mouth small, teeth small and fine. Eye large, an inch from the snout. First dorsal five inches from the snout, placed in a fissure which hides it when closed: its fin rays somewhat spinous, the first two longest and closely united; from first to second dorsal six inches; the latter crescent shaped. Tail lunated, the vertebræ nearly reaching its edge. Ventral fin resembling the second dorsal; finlets eight above, seven below. Pectoral fin small, stout, in a sulcus on the side; its origin immediately behind the gillcovers, and anterior of the line of origin of the first dorsal. Abdominal fins short, stout, lying in a sulcus : and as the sulcus is common to both fins they appear as if lying beneath a scale : round which and reaching to the gillcovers is a patch of scale-covered surface, or cuirass, which two inclies behind the extent of the pectorals contracts into the lateral line, and being marked in its length by the appearance of stitches, passes on to the tail. The scales on other parts of the body beside the cuirass are less distinctly marked, and smooth. The general colour dark blueish, the back distinctly, though obscurely marbled, the lines running longitudinally, with ocellated spots.

$$
\text { J. 9, 7. P. 21. V. 6. A. 8. C. } 15 .
$$

Mr. Yarrell's figure is represented plain: that of Curier ornamented. 
LONG FINNED TUNNY. Scomber alalunga, Linnæus. Orcynus ala longa, Cuvier. Risso, Ichthyologic, p. 169. In my visit to Penzance in February 1841, I found a specimen of this well marked species in the Museum of Natural History there. It was taken in the bay, and is the only specimen known to have been caught in Britain. It may be easily recognized by the great length of the pectoral fins.

BLACKFISH. Centrolophus pompilus, Cuvicr. Yarrell's Br. F., vol. 1, p. 179.

The only specimens of this fish hitherto recognized as British, were taken in Cornwall, and are recorded in the first portion of our Fauna, and in Mr. Yarrell's British Fishes. To these a fifth specimen is to be added, that came close to a boat at St. Ives, and was hooked with a gaff. In this instance its instinct led to its destruction; for it was the opinion of the ancients that this fish was in the habit of following ships at sea, and manifesting great attachment to them, so as not to be driven away by violent attempts to take it. Some obscurity has been thrown on this part of its history, by confounding it with the Pilot fish (Naucrales ductor) which is more frequently seen to manifest the same habits: just as also, the adhesive habits have led to similar errors concerning the sucking fishes, Petromyzon marinus and Echeneis Remora. Compare Oppian, book 1st., with Pliny, book 9, chapter 15.

DOREE. Zeus faber, Linnæus. Yarrell's Br. F., vol. 1, p. 183.

As one object of the Naturalist is to study the habits of the creatures of God, I will record an instance of the voracity of this fish. In a specimen twelve inches and a half in length, I found twenty-five flounders, of which few were less than two inches and a half long; three half grown Sting fishes (Coltus scorpio) and five stones of the beach, of which the largest was one inch and a half long: taken up, as I suppose, in its eagerness after prey. The Cotti were partly digested, the flounders not at all. The Dory was so gorged with its gluttony, as to suffer itself to be taken with the hand.

BOAR FISH. Z. aper, Linnæus. Jenyns' Man,, p. 368. Capros aper, Risso. Yarrell's Br. F., vol. 1, p. 190, 2nd. edition. Zoologist, vol. 1, p. 191, the latter from a British specimen, and differing in several particulars from Mr. Yarrell's figure; that was derived from a fish caught in Madeira. 
It is only of late that this species has been recognized as British : the first on record having been taken in Mount's bay. Another has come to my knowledge, that was purchased in the market at Falmouth in 1841 ; but in July 1811 , on the first adventure to sea of a trawl ressel from the port of Penzance, a very considerable number of this fish was taken. My Son, who was present, counted and examined sixty of them; and the fishermen informed him that they had thrown some overboard, as worthless. The following description was taken from some of those specimens, and compared with others. Length varying from five to seven inches. In one of the latter size, depth in front of the first dorsal spine three inches, girth seven inches. Snout prolonged, and capable of still greater extension, to the length of seren eighths of an inch. Above the eye it is narrow, and it then is arched concavely upward and backward, in a waved form to the origin of the first dorsal, which is the highest point; from whence it slopes backward to the stalk of the tail. The eye large, round, five eighths of an inch in diameter, and the same from the snout when the month is closed. When extended the snout is membranous, and surrounded anteriorly with a rim of bone, forming the jaws; on the upper part of which is a long stout bone which passes into a conspicuous socket between the eyes; and anteriorly it expands on each side like two wings, which terminate in two horns. From the orifice of the socket posteriorly a small slight bone passes obliquely downward and forwards to meet another from the rim of the mouth: thus forming a nearly equilateral triangle with the base above. The rim of the lower jaw is attached loosely to the anterior side of the triangle; and when the mouth is closed the whole of this mechanism resembles a moustache. Teeth small. Scales numerous, large, finely serrated and ciliated; so that the surface has a beautiful silky appearance. Passing the hand backward it felt smooth, but rough in the reverse. The lateral line, though not well marked, was very apparent through the first third of its length, and might be traced throughout. It arose about the fourth of an inch behind the eye, arching upwards near the dorsal fin, and then bending down. Origin of the dorsal, ventral and pectoral fins nearly in a straight line, that of the latter being rather in adrance. First ray of the first dorsal very stout, very short, and alinost unconnected with the others. Second ray five times as long as the first, and curved posteriorly, as are all the others. The third is the longest, all the remainder growing shorter. All the rays are stoul, and with the exception of the first three, are stoutest 


\section{7}

at the middle; they are longitudinally striated, and the first three are more elevated at their root than the others. There are no scales at their base. The second dorsal is soft, and placed on a ridge. Abdominal fin with the membrane not extending to the ends of the soft rays. In Mr. Yarrell's figure the first rays of the dorsal fin are represented as serrated; which was not the case in these specimens; that mark being limited to the first ray of the rentral, which is strongly so.
D. $9,24$.
P. 13. V. 1, 5.
A. 3, 24.
C. 14 .

Colour of the eye bright yellow, and silvery white; of the body a fine crirnson, delicately bright, faded into yellow, and from thence to a silvery white as it approached the belly. There were no lateral bands, as are sometimes described.

Within a few days after the capture of this quantity of these fishes, two others were obtained: and in the week ending the 28th of the same month, about an hundred additional specimens were taken, and all the specimens that passed under observation exceeded two hundred.

\section{GOBIAD AE. GOBIES.}

YARRELL'S BLENNY. Blennius galerita, Fleming's Brit. An., p. 207. B. Palmicornis, Jenyns' Man., p. 380. Yarrell's Br. F., 1st Ed., vol. 1, p. 233. B. Yarrellii, Cuv, and Valenciennes. Yarrell's Br. F., 2nd Ed., p. 263.

My first specimen of this Blenny was procured in 1811; and being rare, and the individual of large size, it was deposited in the British Museum. Since that time sereral have come to my hands; of which two or three were presented from Gorran, by Mr. Peach; and a comparative examination of these enahles me to point out some variations to which this fish is subject, and thus to reconcile the contrariely of description by different Naturalists, of which Mr. Yarrell takes notice. The characters here given are designed to have reference to Mr. Yarrell's figure and description, both in their resemblance and difference. Lips and cheeks tumid, under jaw rather the longer; teeth very small, regular, close set; eyes approximate, elerated. Belly tumid, body lengthened, compressed. Lateral line double, the upper soon becoming obsolete, but having its beginning from a row of pores running back from the summit of the cheek. Membrane of the dorsal and anal fin bound to the caudal. Colour uniform light brown, covered with fine scales, each with a paler rim. Between the eyes a slender process; on the front of the head two, elerated, crowned with a tuft of fibrils; and on the top of the head, above the centre of the eye a more elevated process, which is a tish 
measuring seven and a quarter inches, was three quarters of an inch high: branched like a stag's horn behind and on the top. Separate threads on the neck: the first ray of the dorsal fin with a branching tuft, the second with a couple of shorter fibres.

In another specimen the tufts on the bead were more divaricated; but in all cases the tendrils pointed backward. In most of the specimens the colour was a light brown, with a distinct brown line from the base of the anterior supraocular process, curring round the anterior margin of the eye, and thence descending below the angle of the mouth. At the upper margin of the gills the outlet is formed by a gathering of the skin into a tube.

Fin rays, D. 50,51. P. 14, 14 . A. 35,39 . C. 16,16 . V. 3, 2 .

The ventral fins were soft; in one specimen, with three soft rays; in the other, with two palmate rays.

WOLF FISH, Anarrhichas lupus, Linnæus. Fleming's Brit. An., p. 208, Jenyns' Man., p. 384. Yarrell's Br. F., vol. 1, p. $27 \%$, N. E.

This is a fish of the north sea, and not much disposed to wander from its usual haunts. When therefore I was informed that a specimen had been taken at Fowey, I felt inclined to doubt its certainty. But I have since been informed by Mr. J. C. Bellamy, the author of the Natural History of South Deron, that he possesed a specimen taken in the neighbourhood of Plymouth; and as the usial fishing ground of that port, is off the Cornish land, it renders the report from Fowey nore probable, and is in itself some ground for placing this species in our catalogue.

\section{POLEWIG.}

FRICKLE GOBY. Gobius minutus. Yarrell's Br. F., rol. 1, p. 288, 2nd edition.

I take this to be the species of Goby, which I have never met with on our rocky coast, though it may be not uncom. mon at the moutlis of our more considerable rivers. My acquaintance with it is confined to the Looe; up which riser it adsances with the tide, and again retreats with it. They are less than two inches in iength, and of the general form of the Gobies; but they are remarkable in having the eyes on the summit of the head; under jaw rather prominent. They are without spots, or those regularly tesselated markings so prettily seen in the double spotted Groby; but not represented in Mr. Yarrell's figure of the latter fish: a circumstance as regards the last named fish, that may be ex. plained by our specimens frequenting a rocky shore, which 


\section{9}

is well known to heighten the colours of fishes. The Polewig sometimes abounds in considerable schuls, and seizes a bait with eagerness: habits which are not common to the fishes of this genus. The size of their mouth is too diminutive to admit of their receiving a look; but their firm loldfast of the bait and probably the curvature of their teeth, described by Mr. Yarrell, were the cause that many of them were captured by angling; but they fall off from the book when lified high above the water.

WHITE GOBY. Gobius albus. Yarrell's Br. F., vol. 1, p. 295, 2nd edition.

This obscure species was first noticed by Dr. Parnell; and though appearing sufficiently distinct, from its form and proportions, to be regarded-as a separate species, it affords sonie grounds for hesitation, that none have been examined but such as are clearly in the first stages of their existence.

\section{CLUPEIDAE. HERRINGS.}

WHITE BAIT. Clupea alba, Yarrell's Br, F., vol. 2, p. 202.

Whilst this little fish was considered the young of tho Shad, no search was made for it beyond the region where it had become an article of lusury. Mr. Yarrell was the first who decided it to be a distinct species; and since then it bas been songht and found in other rivers besides the Thames. During the summer of $\mathbf{1 8 4 3}$ the favour of a gentlemen supplied me with a few specimens from the Fowey, which I have been able to compare with some in my collection from the Thames, with which they exactly agree. I am assured that they abound in the Fowey and I consequently concludo that if sought for within the reach of the tide, they might also be taken in the Tamar, and in the Fal, at the least be tween Falmouth and Truro.

CARTILAGINOUS FISHES. CHONDROPTERYGII.

\section{RAIIDAE. RAYS.}

\section{CRAMP RAY. Torpedo.}

The wonderful properties of the Cramp Rays, unlike any thing found in other classes of the animal kingdom beside fishes, and confined to few even of them, has solicited the attention of philosophers at all times; but disregarding the minute differences that form specilic characters, writers on Natural Histury have not judged until receutly that there might be more than one species of the race. And when this has seemed to be probably established, it was still a matter of doubt to which of the acknowledged species the specimens taken in Britain should be assigned a matter 


\section{0}

still remaining in doubt, as the 6sh is not often taken, and when it occurs a competent observer may not be present to take advantage of the circumstance. The examination of a single specimen therefore becomes a matter of interest; since it may enable us to settle the value of the assumed marks of distinction, and to assign the synonyms of our British species.

The descriptions we possess of these fishes represent the specimens as having great variety of colour; as may be seen in Risso's plates (Ichthyologie de Nice pl. 3,) where one is of very pale brown, with slight but numerous pale blue spots, and a larger ocellated spot of deeper blue on the centre of the disk: with a pale waved line from each temporal orifice to the tail. In another the colour is a uniform reddish buff; and the third is a dull brown, thickly covered with small dark spots. In Matthiolus' edition of Dioscorides, the colour is described as reddish, with five regularly arranged large ocellated spots; which are seen only in the adult fish. Gesner (Nomenclator aquatilium, p. 124,) gives two figures, in each of which five large spots are regularly distributed; but they differ from that of Matthiolus in having the spot which lies in a direction with the dorsal line, close behind the head; whereas in the figure of the latter author this intermediate spot is the most remote from it. When we add to this, that in most of the Ray kind there is a disposition to formation of spots and circles, but that they vary in their occurrence, form and situation, and that the supposed Cuckow Ray ( $\boldsymbol{R}$. miraletus) derived its only authority from these accidents, we may safely venture to conclude that little dependence should be placed on them for the distinction of species. They have not usually occurred in the specimens taken in Britain, and I believe not at all on those seen in Cornwall: in which they confirm a remark that I have several times had occasion to make-that the fishes of the Mediterranean which occasionally wander to our shores, invariably suffer a change of colour:-a circumstance to be explained by the fact, that a variation of ground or light eflects great alteration in the shades or distribution of the colours of fishes.

But whilst the circumstance of colour or spot must be held doubtful, another mark is claimed as decisive of the distinction of species. This is the uniform continuity of the margin of the temporal aperture, or the having that part cut into segments: the Torpedo marmorata, or old British Torpedo of Mr. Yarrell's British Fishes, vol. 2, p. 542, second edition, being characterized by the latter, the Torpedo nobiliana, or new British Torpedo, vol, 2. p. 546, 


\section{1}

by the former mark. A large specimen of this last named species was taken in the Monnt's bay, and is well preserved in the museum of the Society for Natural History at Penzance. From an examination of this $I$ derive the following description: length three feet two and a half inches; extreme breadth two feet three inches; the margin much rounded, and expanding much more than in either of Mr. Yarrell's figures. Mouth narrow, and apparently feeble, the under jaw curved forward in the shape of a horse shoe; teeth snall and sharp; temporal spiracles with an even continuous border. Colour of the upper surface deep brown, the skin smooth, sprinkled with small shot-like spots having some approach to regularity of distribution. The posterior lobe of the body has a regular fin with nineteen rays, of which three at the two extremities single, the others double. Of the two dorsal fins the anterior is partly on the lower lobe of the body, two inches and a half long, two inches and three quarters high; the distance between them two inches and three eighths. Second dorsal one inch and a half long, two inches high; from which to the caudal fin, two inches and a half. Eyes small, two inches and three eighths apart.

Mr. Dillwyn (History of Swansea, p. 61,) describes a specimen clearly similar to the above, that measured in length forty-two inches, thirty inches wide, and weighed forty-three and a half pounds, and an observation of that genteman on his specimen before and after it was set up for preservation, will explain much of the discrepancy observed in the descriptions and ligures of these fishes given by different authors. With the utmost care that was employed, the specimen, between the time of its death and preservation was found to have stretched from forty-two to forty-nine inches in length, and to have diminished in breadth from thirty inches, to twentyfour, a circumstance which will explain the disproportionate dimensions of Risso's figures, and the want of expansion in even the British engravings. The specimen at Penzance had been measured previously to setting up; and it is now fixed on a board suited to its natural figure.

\section{SQUALID AE. SHARKS.}

HAMMERHEAD. Squalıs zygæna. Linnzeus. Risso, Ichthyologie, p. 34. 'Zygæna malleus, Jenyns' Man., p. 507. Yarrell's Br. F., rol.2, p.504.

More than a single specimen of this curious and voracious Shark, have been taken in Corowall; but the only one preserved, is in a dissected state in the museum of Natural History at Penzance. 
SHELLS.

NATICA INTRICATA. Natica intricala, Fleming's Brit., An., p. 319. Natica intricata, Donovan's Br. Sh., t. clxvii. Natica canrena, Montagu's Test, Brit., Sup. 148.

The only British Naturalist to whom I am able to refer, for information concerning the Natica intricata, is Dr. Fleming, who in his History of British Animals gives the authority of Donovan's British Shells, under the name above given, ard to Colonal Montagu, who terms it $N$. canrena; but he adds, "this species has occurred only to Mr. Donoran." And when I add, that Professor E. Forbes (Malacologia monensis, $p .62$ ) supposes it to be the same with $N$. nitida, and that it is not to be distinguished from some otber foreign species, it will be allowed to be of rare occurrence; and I am therefore led to hope that a descripion of it, derived from more than one example, and compared with the kindred species $N$.glaucina of about equal size, and hoth of these with several smaller specimens of each, will be found interesting.

The shell termed by Fleming $N$. intricata has too rarely come within the observation of British Naturalists to have receired so many names, as the fancies or mistakes of authors have affixed to the more common species. But to aroid all errors in reference it is necessary to say, that under the name Natica glancina is meant that which by Pennant is denominated Nerita gluucina, and it is believed, also by Nontagu: by Fleming Natica glaucina. Professor Edward Forbes, as quoted above, terms it Natica monilifera, from a supposition that it may be the shell so called by Lamark; and the same is adopted by Macgillivray: (Molluscous Animals of Aberdeen \&c., p. 125.)

In September of the present year (1844) I obtained a specimen of Natica intricata, from Penzance, and this I supposed to be the first I had ever seen. But in the course of the same month I obtained a much larger sfecimen from Plymouth sound; and a comparison of this pair with a fine specimen of the more common $N$. glaucina will enable me to give a measurement and description which will in some measure fix the identity of the rarer species.

The smaller specinen of $N$. intricata here referred to, measured ten twelfths of an inch in its longest diameter; but the larger, which was serenteen twelfths in its longest diameter and thirteen twelfths in its shortest diameter, afforded a closer comparison with $N$. glaucina; my largest specimen of which is sixteen by thirteen twelfths in these diameters. The latter, therefore is a rounder and more compact shell, the greater comparative length of $N$. intricata being obvious on inspection. They differ also in the ar- 


\section{3}

rangement, as well as in the number of the whorls; which in $N$. glaucina is clearly six, but in $N$. intricata no more than five can be ascertained. In $N$. glaucina the second an:l the smaller whorls are more inflated, and form a higher spire, the decreasing line of separation liaving a regular circular sweep; whereas in $\mathbf{N}$. intricata, beside that the wholo is much more depressed, the spire is not placed in the centro of the whorl, but inclined to the superior sille. Another distinguishing mark is the form and situation of the umbilicus; which in N. glaucina is a simple ascending cavity, intruded on by a single porcellaneous band, which proceeils from the columella. In $N$. intricata this band is divided so nearly into two, that the connection is ouly by a narrow slip; and the eleft or separating gap, which in the smaller specimen is rounded and in the larger square, exposes the umbilicus above the columella, and therefore passes directly inward, instead of obliquely upward as in N. glaucina. Tho pillar tlias becomes exposed uncovered by the band on one side and the body whorl on the other, in a manner to be highly characteristic of the adult shell. The inferior portion of the band does not stretch fully across to the whorl, but is rounded off by a narrow channel, which proceeds circularly to terminate within a short distance of the aperture : offering, in fact, a broad and smooth porcellaneous separate termination to the pillar.

In colour N. intricata is much the most beantiful of English turbinated shells; the two specimens differ much in the depth, though not greatly in the distribution of their tints. In the larerer it is far more rich, of a fulvous brown; in the smaller lighter, and of a porcellaneous yellow. The smaller whorls are in the larger somewhat livid; yellow at the separating line: in the larger, a pale yellow; and the beauty of the colouring does not begin above the lower half of the second whorl; from which it descends into four regular lines, at nearly uniform distances, to the margin. These lines are in their ground lighter than the other portions of the surface; and their margins are well delined; they are also portioned out and intersected, with some regularity, by arrow shaped marks; of which those in the two middle are the most regular. The two external lines are the widest, and their arrows broader, and more separate, but that which is nearest the separating line of the whorl wost irreglilar. Tho line nearest the umbilicus (separated from it bowever, by a white space) is in the smallest specimen ornamented with regularly forned arrows, but in tho larger one side only of this marking appears. The marks here denominated arrows are converging lines closing to a point as they de- 


\section{4}

scend, and at this part with more of colour; but they have no middle line; and in the larger specimen tiseir form is much less regular than in the smaller. From the line of separation of the whorls run a considerable number of brown lines, encircling the convexity of the whorls, and miting the longitudinal lines of arrowy marks, but not actually breaking in on their continuity. The comparative number of these encircling lines, as well as their regularity, is much greater in the larger specimen.

A close inspection of these shells in comparison with a small parcel of Natica, of about the size of sniall peas, and which without enquiry I had believed to be all of the more common species, has impressed me with the belief that the $N$. intricata is not so rare as has been supposed; for I found several among them distinguished by the regular lines of arrow shaped marks, and thereby easily separated from others of paler cast, and with only one line of obscure linear marks near the border of the whorl. On further examination I find also on these prettily marked specimens that the spire is less elerated, and possesses the general form already described as belonging to $N$. intricata. But it is remarkable that in the umbilicus and band all these specimens are alike, and resemble $N$. glaucina: a circumstauce which does not excile in my mind any doubt of their being of different species, and that those haring lines of arrow shaped marks are a yonng state of $N$. intricata; for I believe that the obserration of Professor Forbes may be depended on: that colour in the Naticæ is distinctive of species, but at the same time it tends to show that in their younger condition they resemble each other in that which subsequently constitutes their most inportant difference. In their youthful condition, then, the marking of the body-whorl, and the depressed and irregular form of the spire must be regarded as the chief distinctions; to which in the adult state must be added the situation and structure of the band and the umbilicus intersecting it; but low far this shell is thus separated from the foreign species of Naticæ described by authors, I have not the means of knowing.

\section{CYPRAA. COWRY.}

MONEY COWRY. Cyprca moneta, Turton's Lin., vol. 4, p. 312 .

This species is a common native of the Mediterranean, and the few dead specimens which had bcen found on the Cornish shores were judged to have been thrown where they where they were discorered, l,y some accident. But in the month of August 1844, a small specimen with the aninal alive, was taken in a trawl in Mount's bay; and it is now preserved in the collection of Mr. R. Q. Couch at Penzance. 


\section{NDEX.}

The names of the Families are printed in LARGE CAPITALS: those of the Genera

in SMALL CAPITALS: those of the Species in Roman Characters: the Synonyms in Italics.

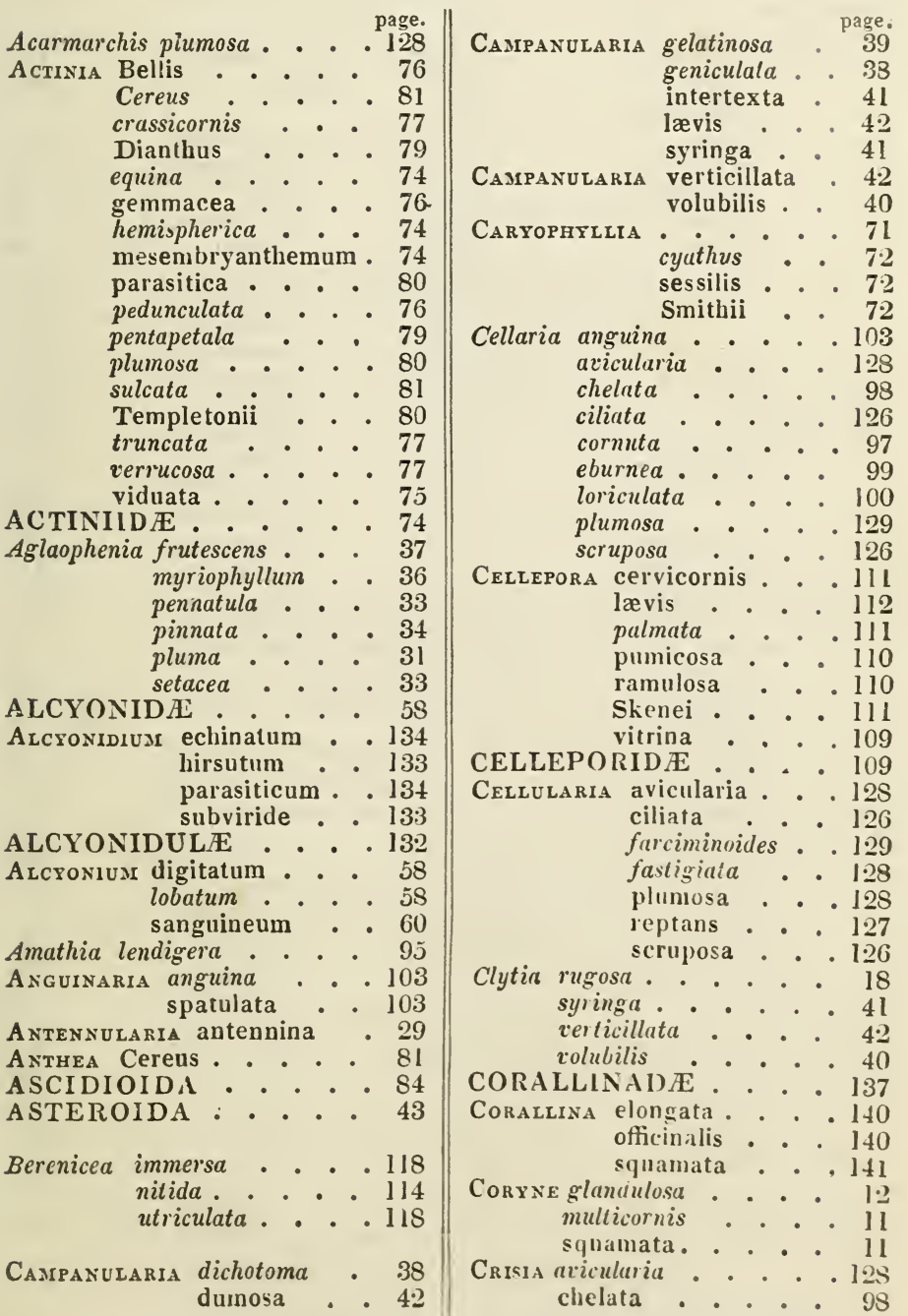


INDEX.

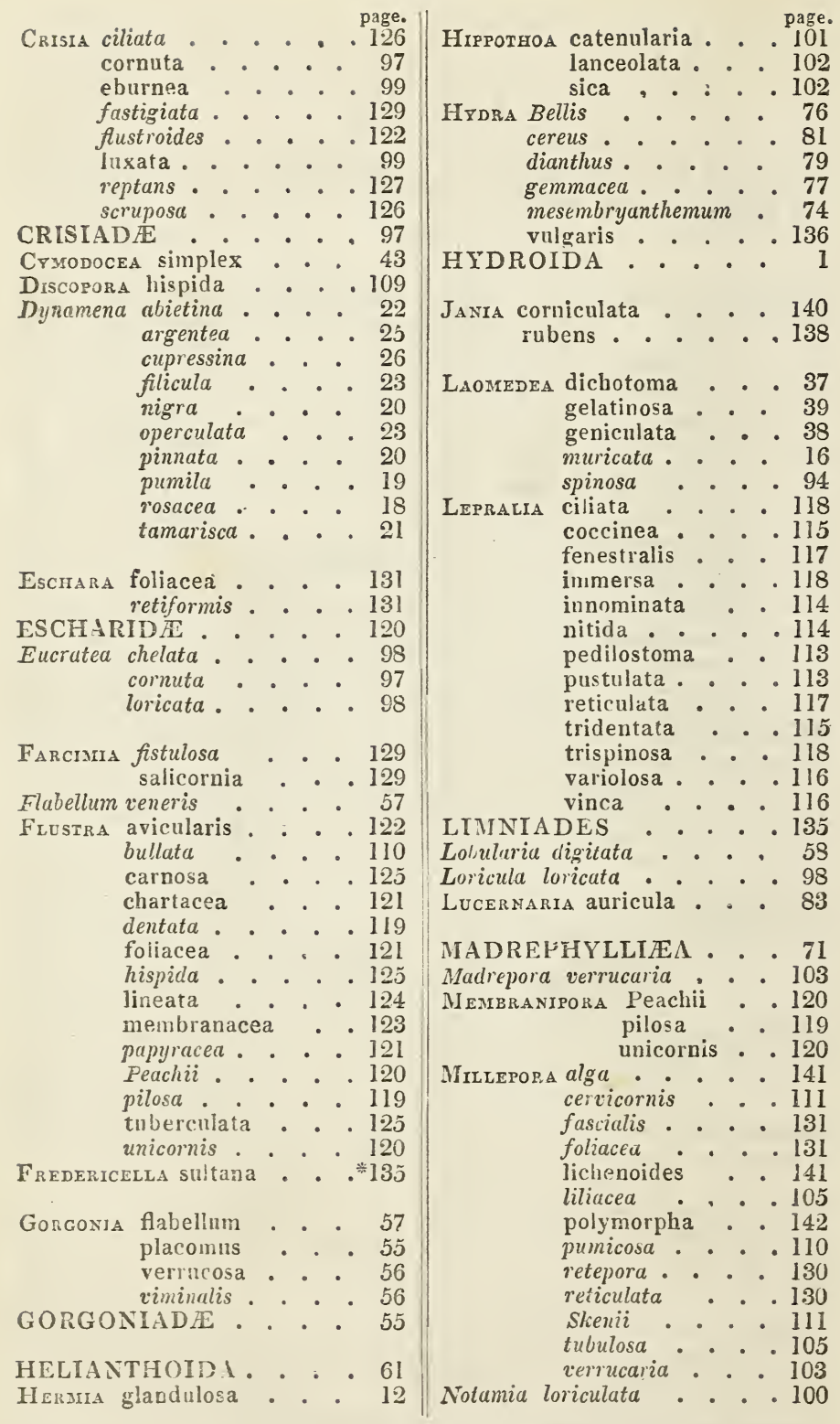

When speaking of this species it was omitted to be noticed, that it was first discovered in Cornwall, as well as the Hydra, by Mir. J. Ralfs. 
INDEX.

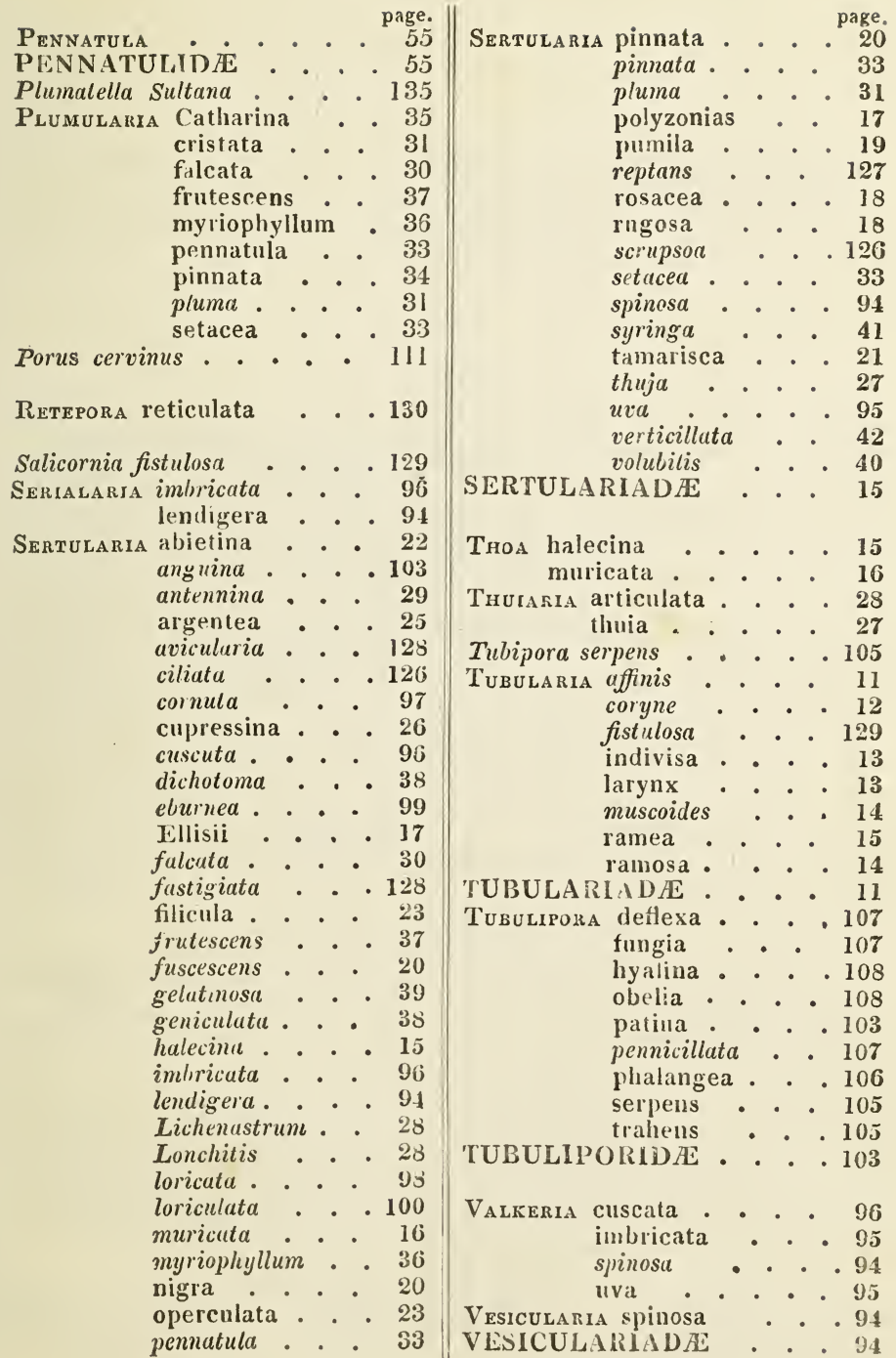



The following Synopsis of the GENERA of Zoophytes is arranged so as to assist Persons, unacquainted with the subject, to identify them by considering the external forms only.

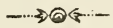 \\ * No Polypidom.}

egg shaped, with one circle of tuberculated tentacula, locomotive . . . . 136 of retractile tentacula, locomotive $\cdot \dot{x_{1}} \cdot \dot{\vec{r}}$

Polypes, single, naked, conoidal or columnar, with several circles of partially retractile tentacula, $\}$ A NTHEA . . . 81 locomotive $\cdot \cdot \cdot \cdot \cdot \cdot \cdot \cdot \cdot \cdot \cdot \cdot \cdot\}$

Polypes single, naked, campanulate; tentacula in Lucernaria. - 83

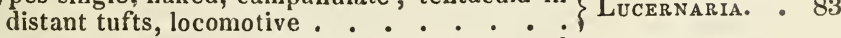

$\left.\begin{array}{c}\text { Polypes single, naked, egg-shaped, with scattered } \\ \text { filiform tentacula }\end{array}\right\}$ ConxNE . . . 11

Polypes single or compound, tentacula irregular, with glandular tips. Polypidom, if present, Hermia. . 12

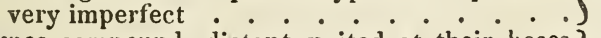
$\left.\begin{array}{l}\text { Polypes compound, distant, united at their bases } \\ \text { by an encrusting trailing band . . . . }\end{array}\right\}$ Zoanthus . . 73

Polype-mass spongy, covered with stellate depres- ? Alcronium . . 58
sions * * With horny Polypidoms, external.

$\dagger$ Without cells.

Polypidoms long, simple tubes, open at the extre-
mities Tubularia . . 13

Polypidoms tubular, closed at the extremities . - Fredericella . 135

\section{$\dagger+$ Cells sessile, biserial.}

$\left.\begin{array}{c}\text { Polypidoms arborescent, formed of sub-parallel } \\ \text { tubes; cells indisinct, tubular or campanulate }\end{array}\right\}$ Tнол . . . . 15

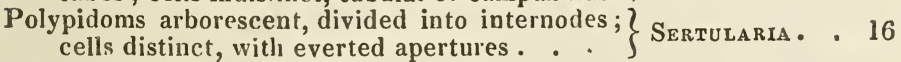

Polypidoms arborescent, divided into internodes; $\}$ Thutaria. . . 27 cells distinct, imbedded . . . . . . . S Thutaria. • 27

$\dagger \dagger+$ Cells sessile, uniserial.

Polypidoms arborescent, with plumose branches . Plumularia. . 30

Polypidoms arborescent, branches in whorls round $\}$ Antrennularia. 28

\section{$\dagger+\dagger \dagger$ Cells sessile, irregular.}

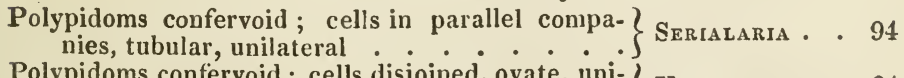

$\left.\begin{array}{c}\text { Polypidoms confervoid; cells disjoined, ovate, uni- } \\ \text { lateral . . . . . . . . . }\end{array}\right\}$ esicularia. . 94 Polypidoms confervoid; cells irregularly clustered,
elliptical . . . . . . . . . . . 95 
$\dagger+\uparrow \dagger+$ Cells on ringed footstalks.

Polypidoms confervoid; cells campanulate; stem jointed, cells rising from thickened parts of LAOMEDEA . . 37 the stem

Polypidoms confervoid ; cells campanulate, continuo!s with the stem, irregular ......

\section{* * * Polypidoms internal. \\ + Horny, rooted.}

Arborescent, fleshy, warty, with star-shaped de- ? pressions, rooted

\section{$+\dagger$ Bony, free.}

Polypidom linear, feathered at one end . . . Pennatula . . 55

Polypidom linear, with curved lines on either side. Virgularia. 55 **** Polypidoms external, calcareous.

Columnar or conical, upper surface lamellated. - Caryophyllia . 71

Arborescent, or foliaceous, stout; cells immersed, ? quincuncial, on the upper side only .... Reterora . . 130

Arborescent, or foliaceous, cells inmersed, quin-? cunical, oval; cells on all sides : . . . . 5

Arborescent, jointed, cylindrical, cells immersed, quincuncial, rhomboidal; cells on all sides . . FArcimia. • 129

Arborescent, cells oval, distinct and irregularly ? heaped........... . .

Arborescent, confervoid, jointed; cells tubular, ? apertures ronnd, terminal. . . . . . . C CRISIA. • . 97

Arborescent, confervoid, jointed; cells oblong, ? apertures opening on one plane ..... $\}$ Cellutaria. 126

Arborescent, confervoid, jointed ; cells sub-cylin-? drical in pairs, apertures lateral and sub-ter- $\}$ Notamia . . 100 minal . . . . . . . . . . . . Polypidoms creeping, cells erect, spathulate, aper-
tures sub-terminal . .

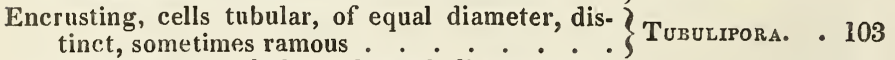

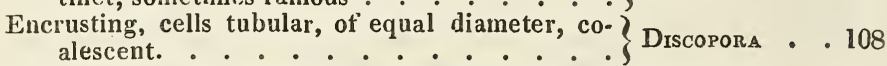

Encrusting, cells elliptical, linked together like beads Hгтротно A • . 101 Encrusting, cells oval, with contracted terminal
apertures Lepratia. . . 113

Encrusting, cells oval, with calcareous or ossified $\}$ Membranipora. 118

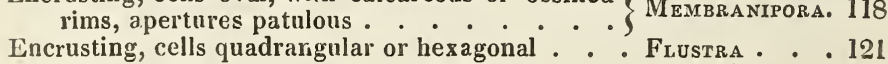
***** Polypidoms spongy.

Cells immersed, irregular, with contractile apertures Accyonidium . 132

Cells in tubes. 


\title{
INDEX TO THE PLATES.
}

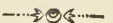

Several errors having crept in relating to the figures, the reader is requested to correct such as may occur by the following revised list.

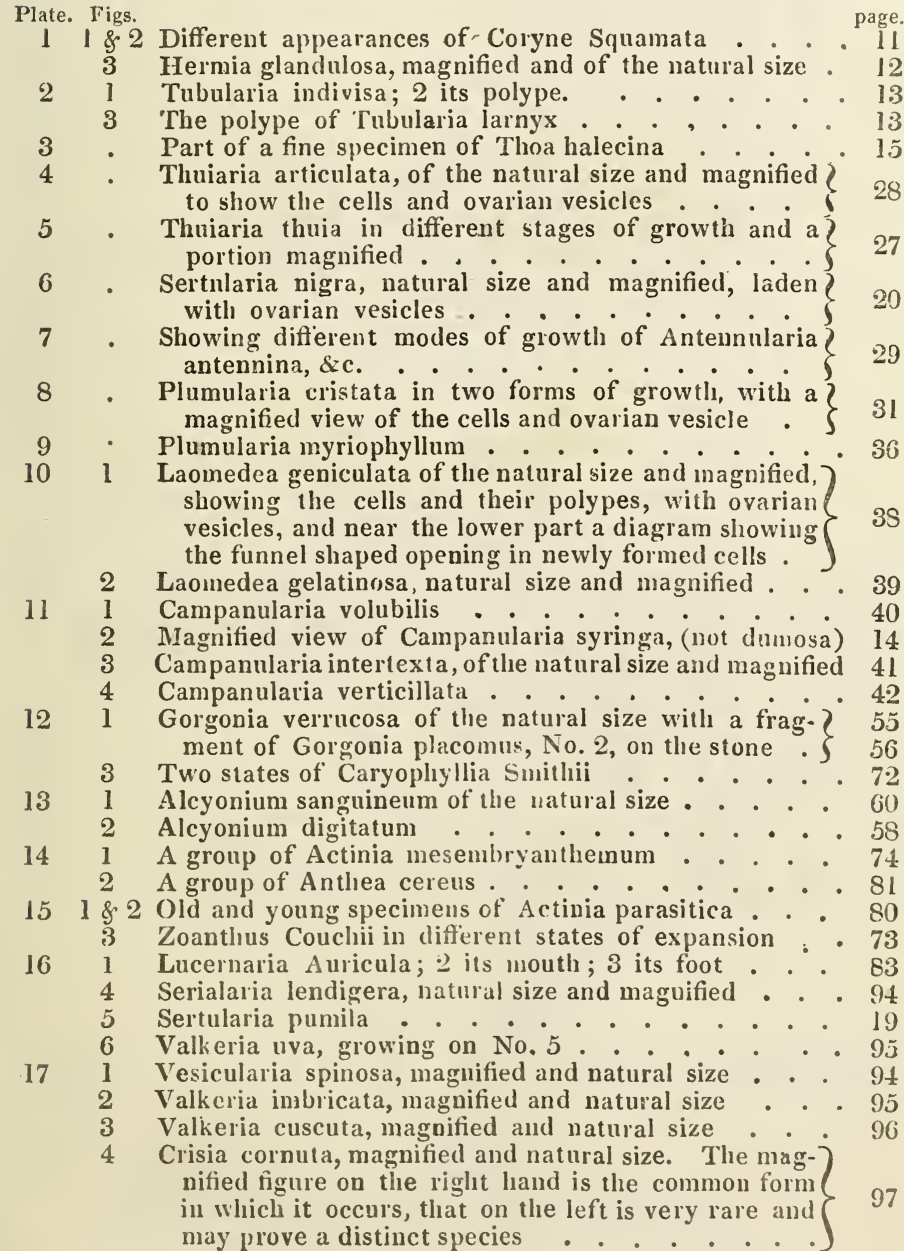




\section{INDEX TO THE PLATES.}

Plate. Figs. Crisia clielata, magnified and of the natural size, with? a figure of its polype ........

Crisia Eburnea, magnified and of the natural size . . 99

3 Crisia luxata . . . . . . . . . . . . 99

4 Notamia loriculata . . . . . . . . 100

5 Hippothoa catenularia, natural size and magnified 101

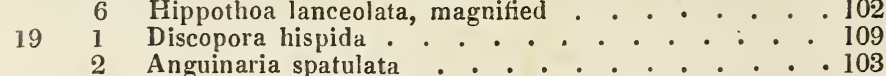

3 Tubulipora trahens . . . . . . . . . . 105

4 Tubulipora fungia . . . . . . . . . . . 107

5 Tubulipora deflexa . . . . . . . . . 107

6 Tubulipora hyalina . . . . . . . . . . 108

7 Tubulipora serpens . . . . . . . . . . 105

8 Tubulipora phalangea . . . . . . . . . 106

209 Hippothoa sica, magnified . . . . . . . . 102

1
2 Cellepora cervicornis . . . . . . . . . . . 111

3 Farcimia Salicornia . . . . . . . . . . 129

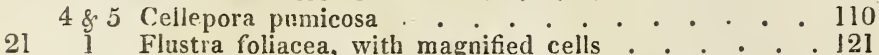

2 Flustra membranacea, with magnified cells and ova- $\} 123$

221 Cellepora vitrina, magnified. . * . . . . 109

2 Lepralia pustulata, magnified . . . . . . . 113

3 Lepralia nitida . . . . . . . . . . . . . . 114

4 Lepralia innominata .. . . . . . . . 114

5 Lepralia tridentata. . . . . . . . . . . 115

6 Lepralia variolosa . . . . . . . . . . 116

7 Lepralia vinca; the cells are proportionably rather? too large and the transverse punctures rather too $\} 116$ small

8 Iepralia fenestralis $: \circ . \div 117$

9 Lepralia reticnlata . . . . . . . 117

10 Lepralia ciliata . . . . . . . . . . 118

11 Lepralia insignis. This species was detected too late? for insertion in its proper place. It is not uncommon near low water mark . . . . . . . .

Membranipora pilosa . . . . . . . . . 119

13 Membranipora Peachii . . . . . . 120

14 Lepralia pedilostoma . . . . . . . . 113

15 Flnstra lineata . . . . . . . . . . 124

231 Cellularia ciliata $\ldots \ldots 126$

2 Cellularia scruposa . . . . . . . . . . 126

3 Cellularia reptans . . . . . . . . . . . 127

4 Celiularia plunosa . . . . . . 128

Omitted in the Index.

Zoanthus Conchii . . . . . . . 73

L. E. Gillet, Printer, 4, Prince's Street, Truro. 

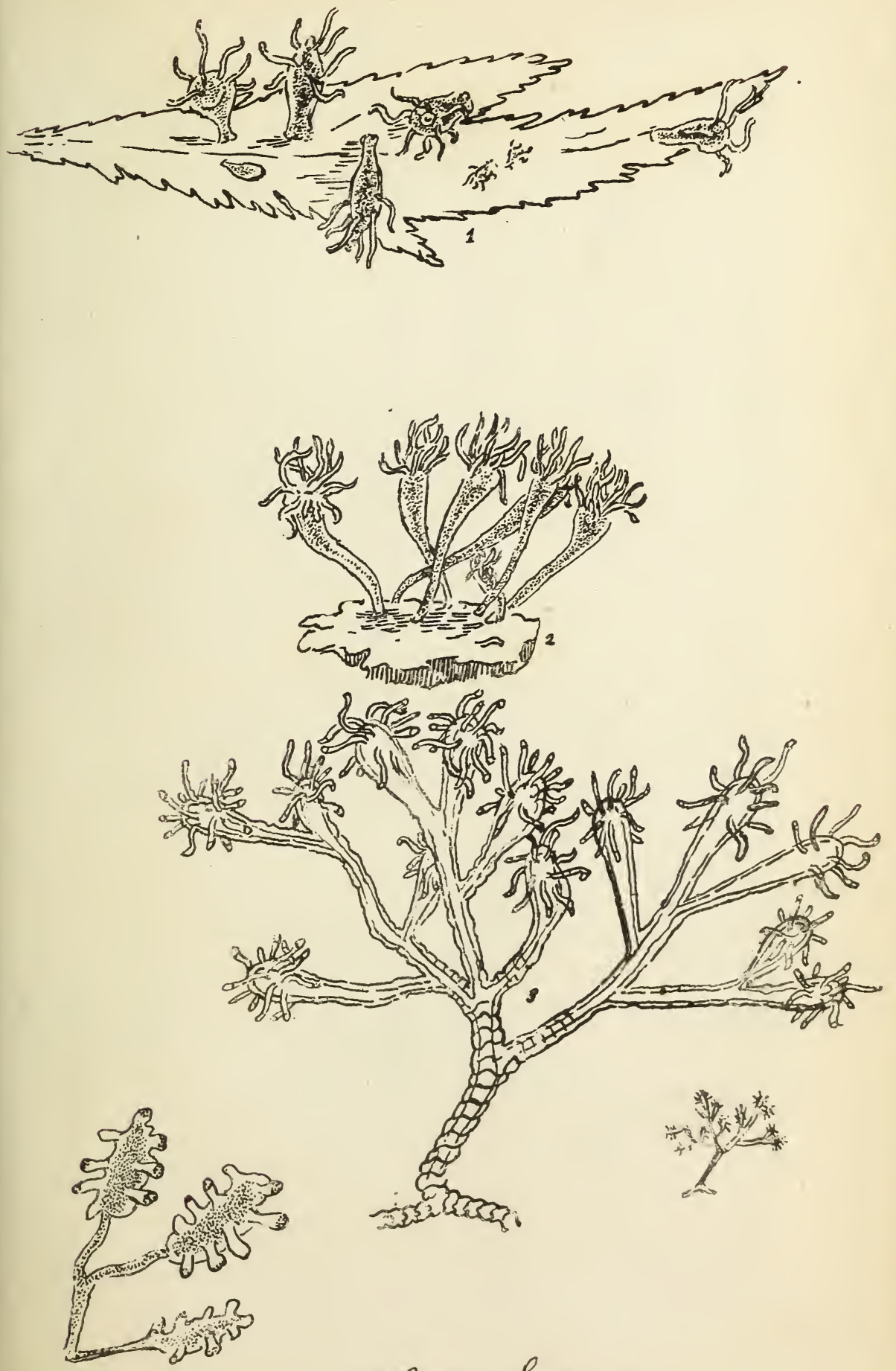

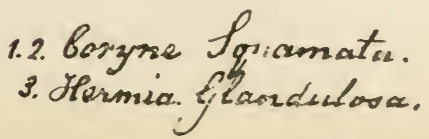



PZ. 2.
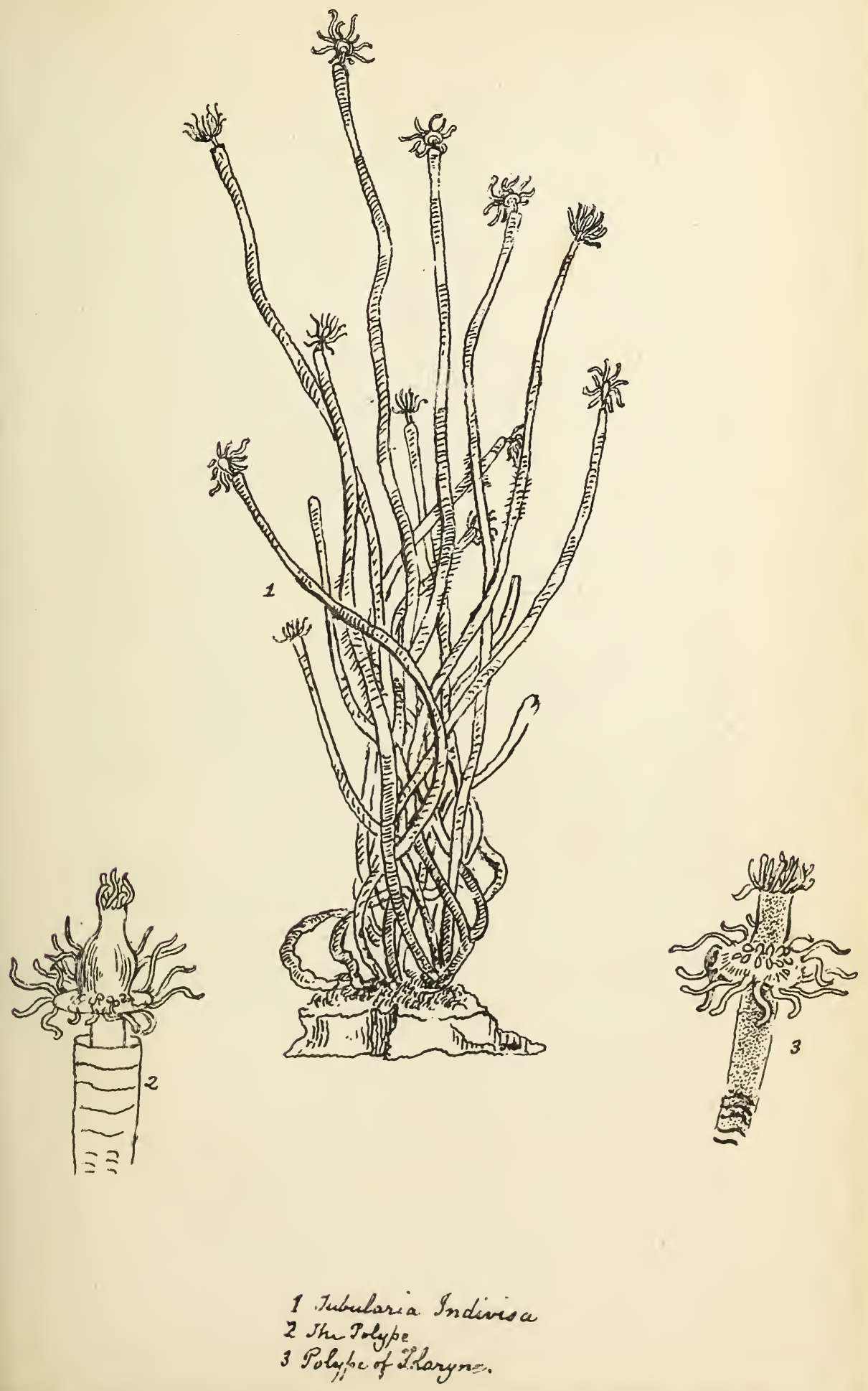


Pl. 4 .

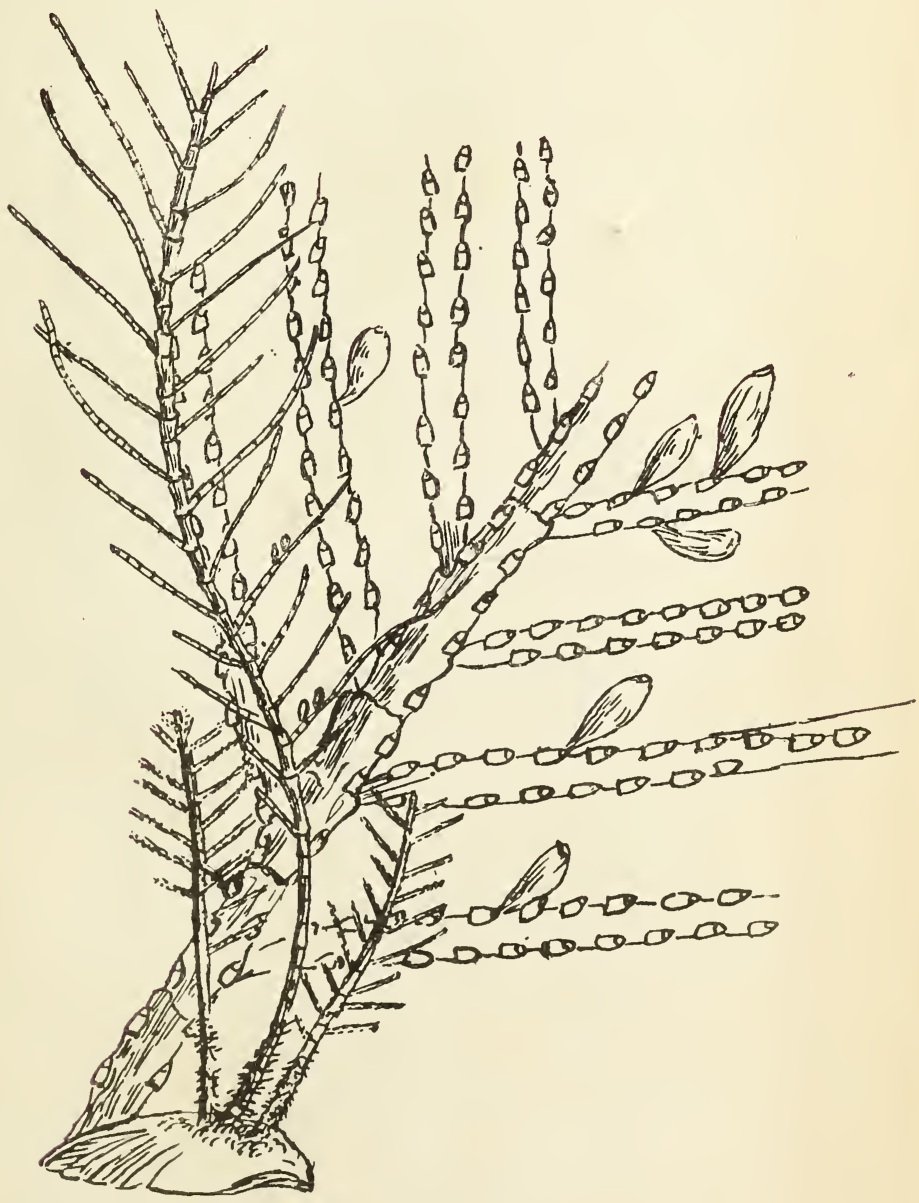

Jinciania Mrticulatata. 



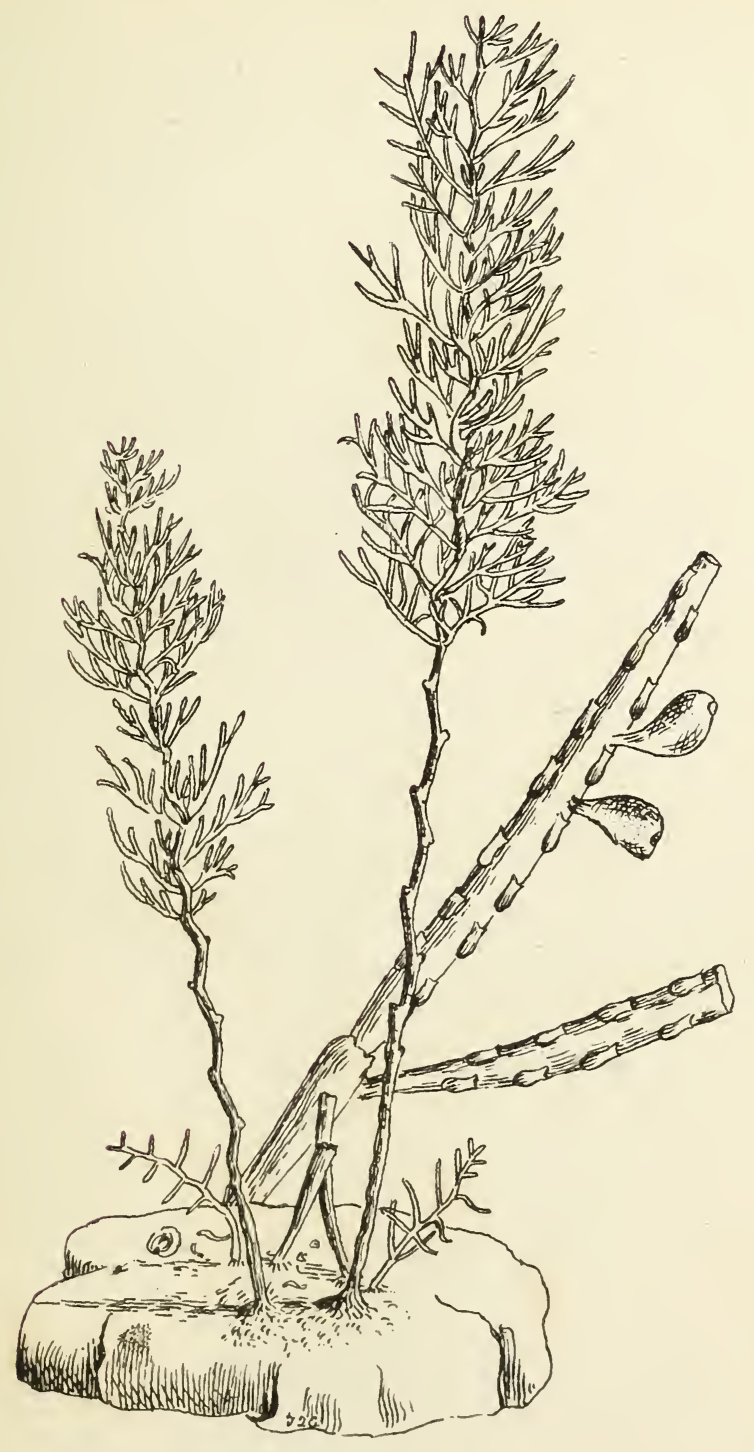

Shuiarice othuico. 



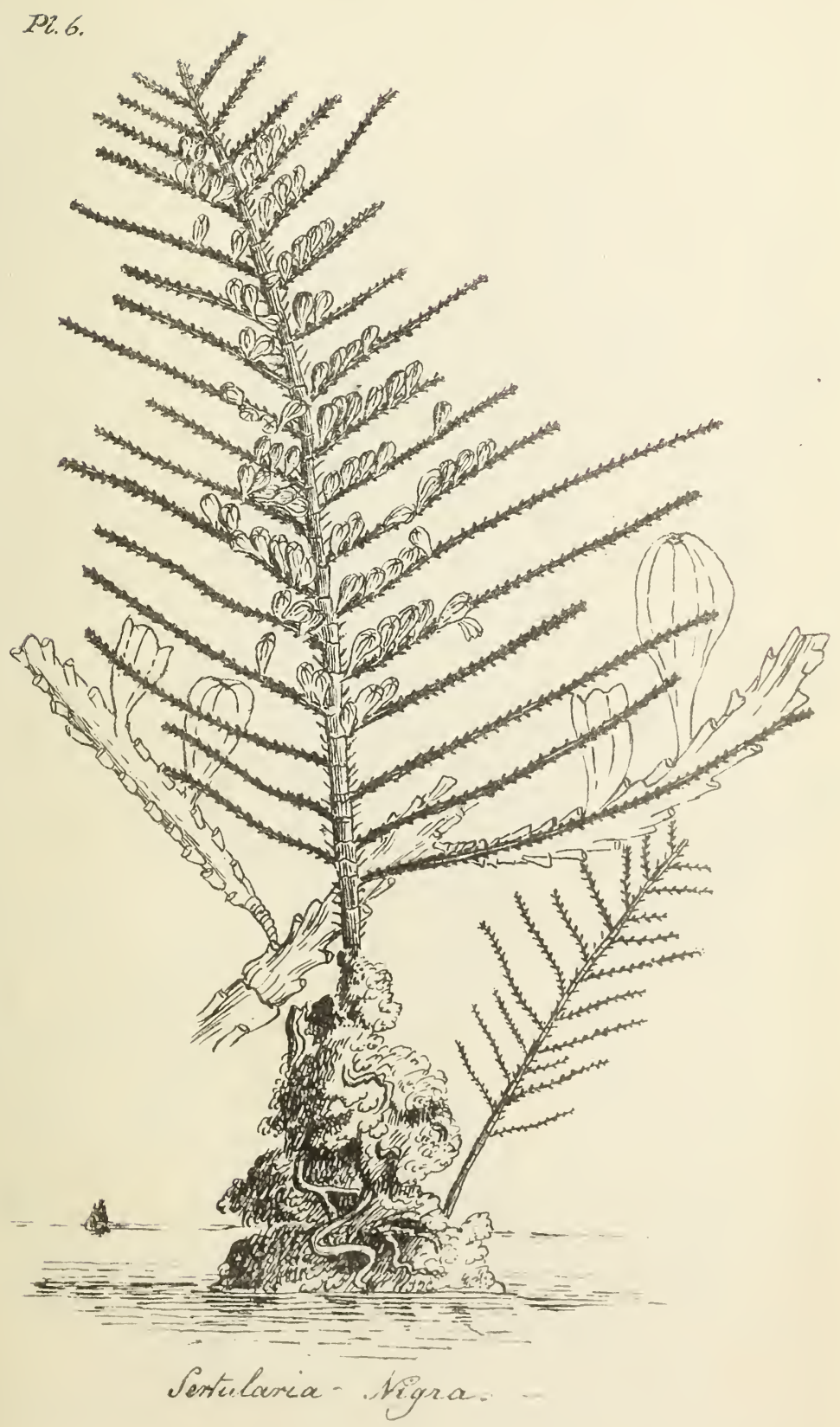



PLY.

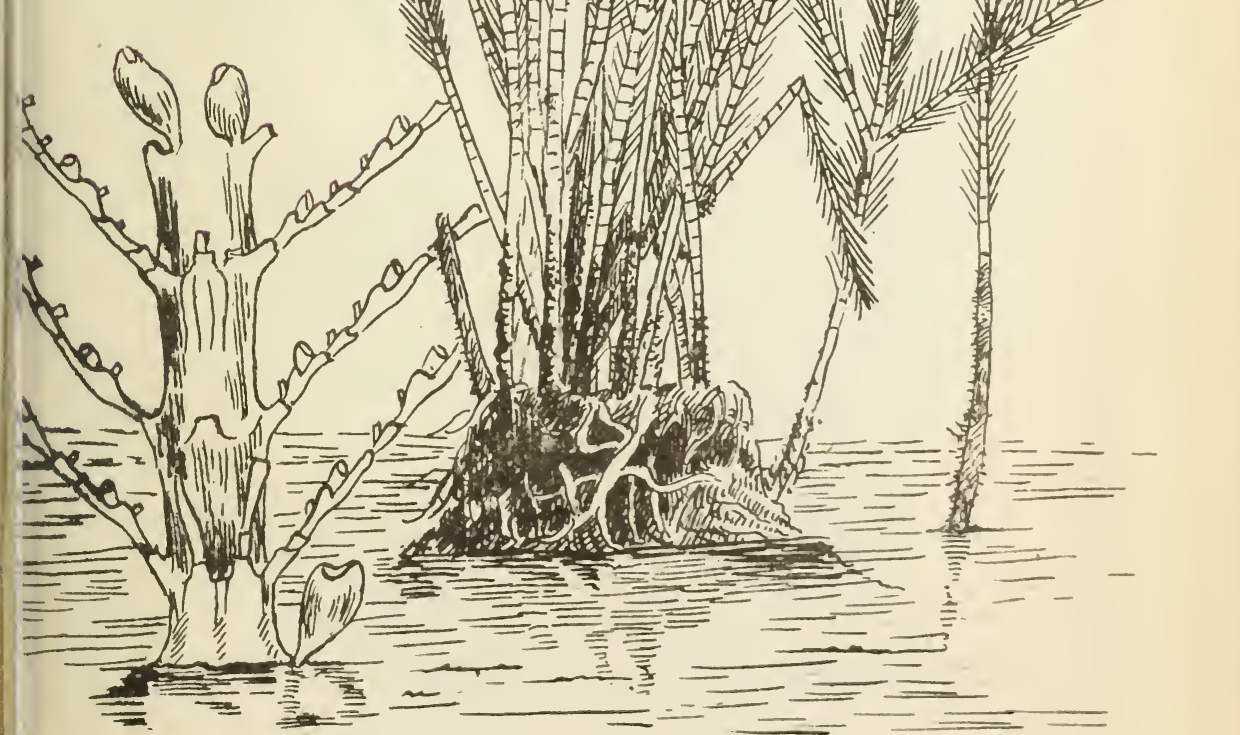

Anten. Antenonina- 



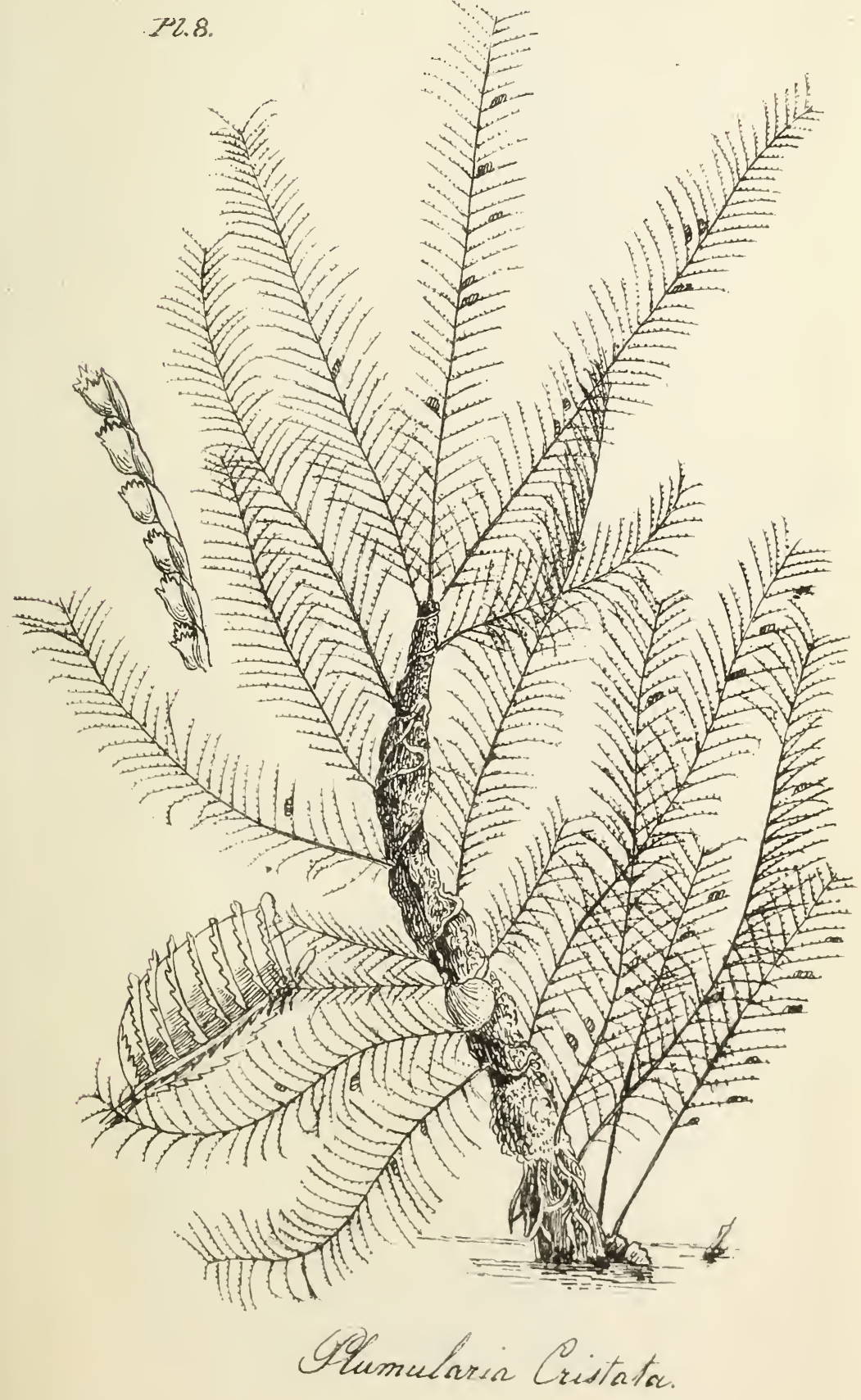



Plg

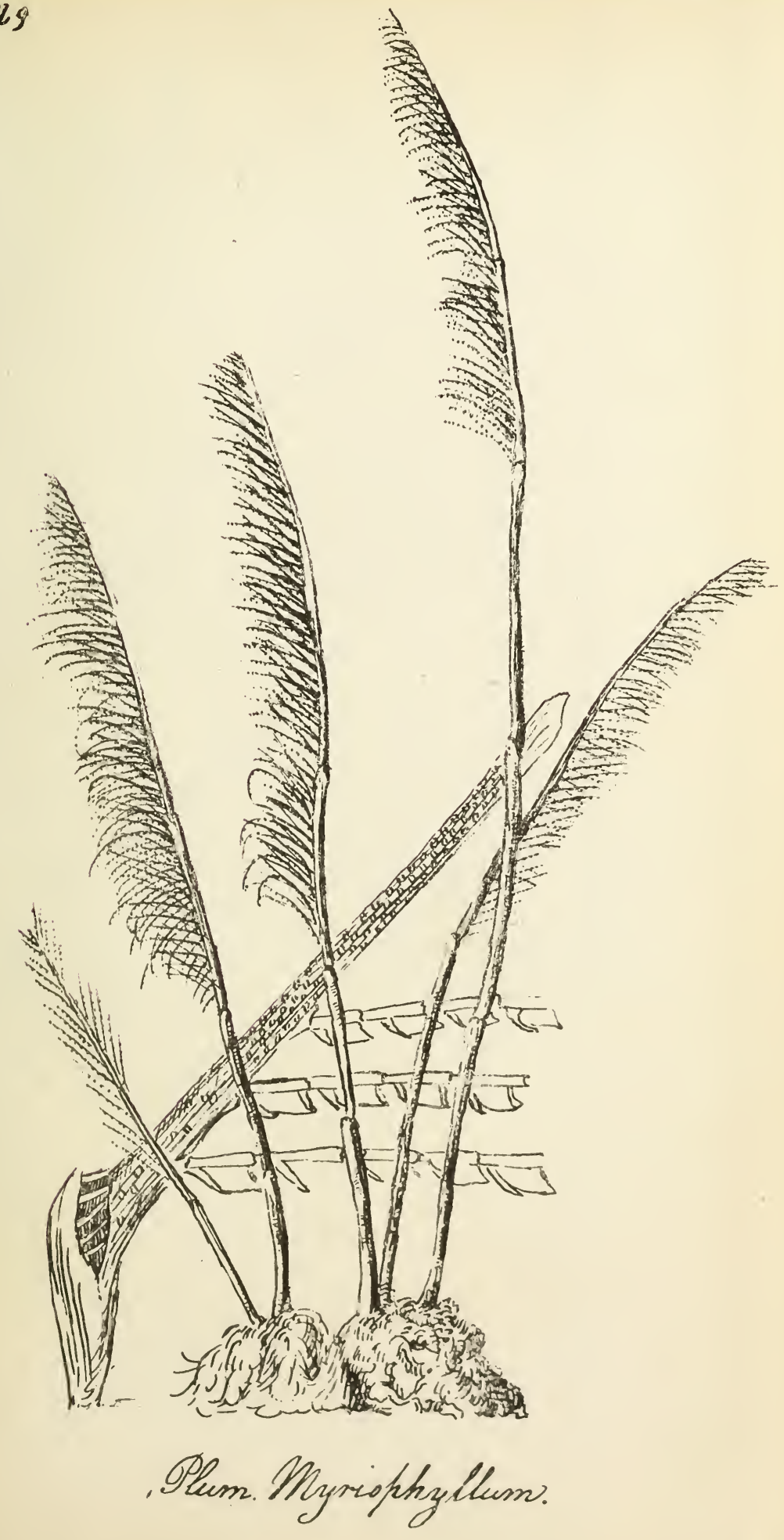





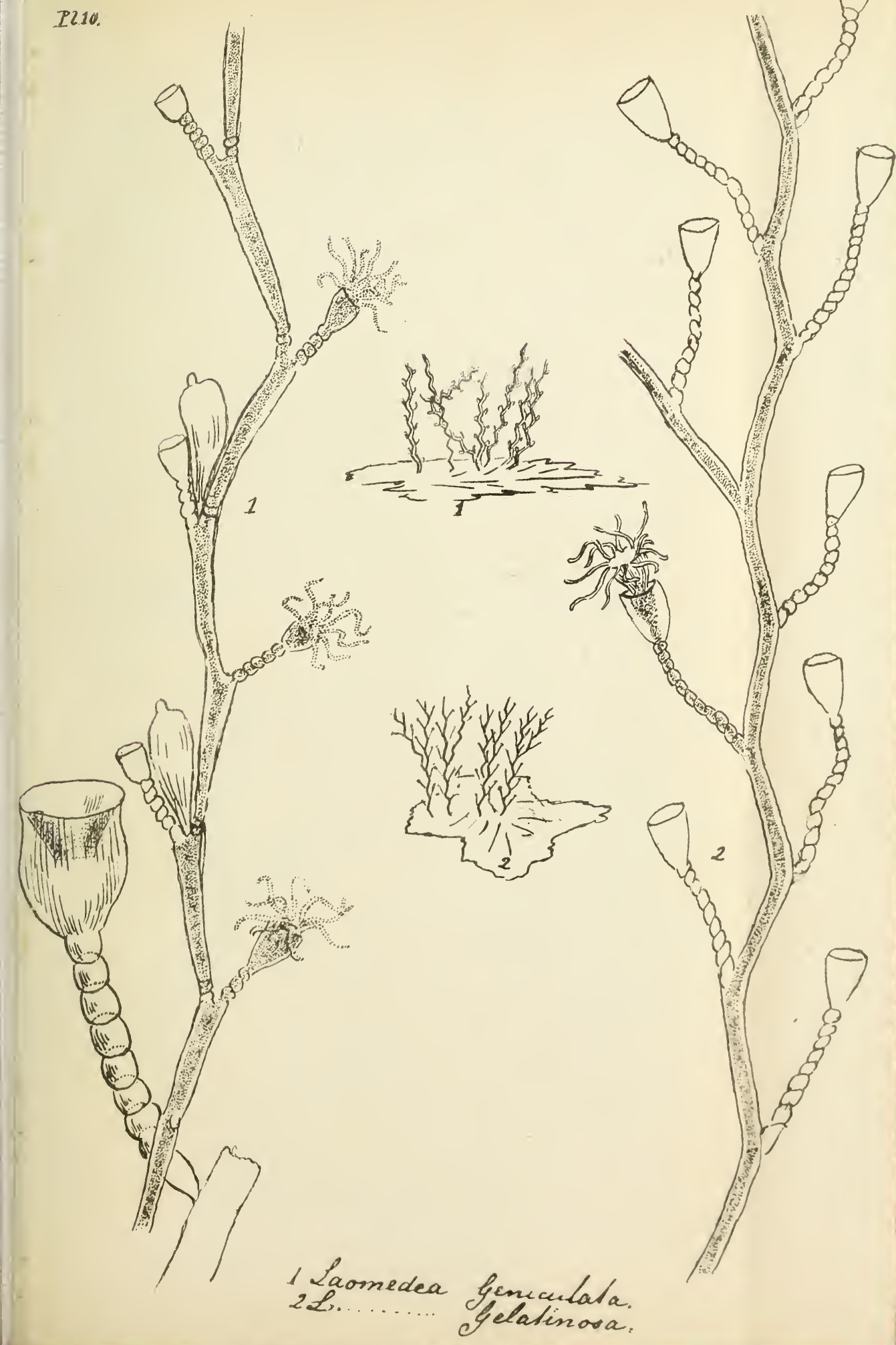




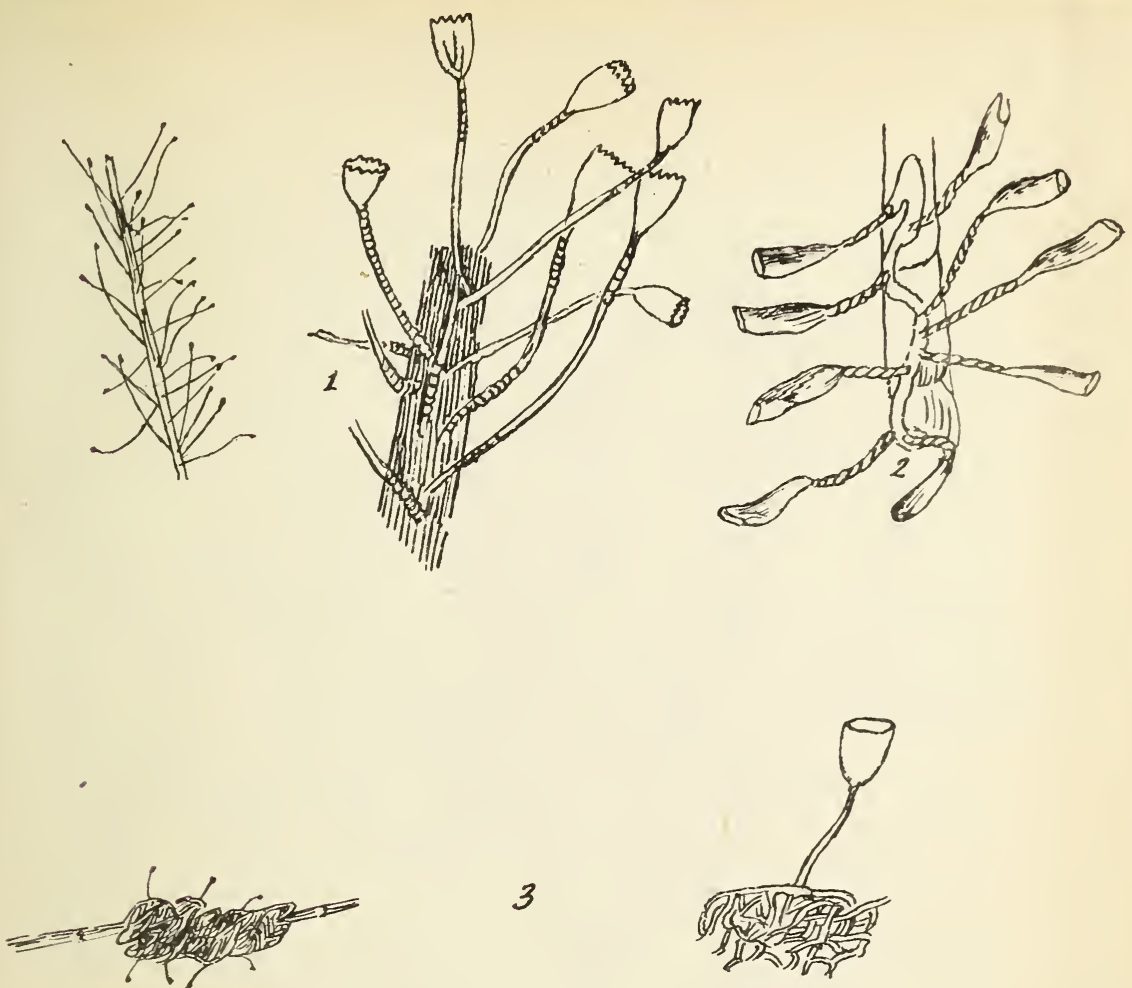

3
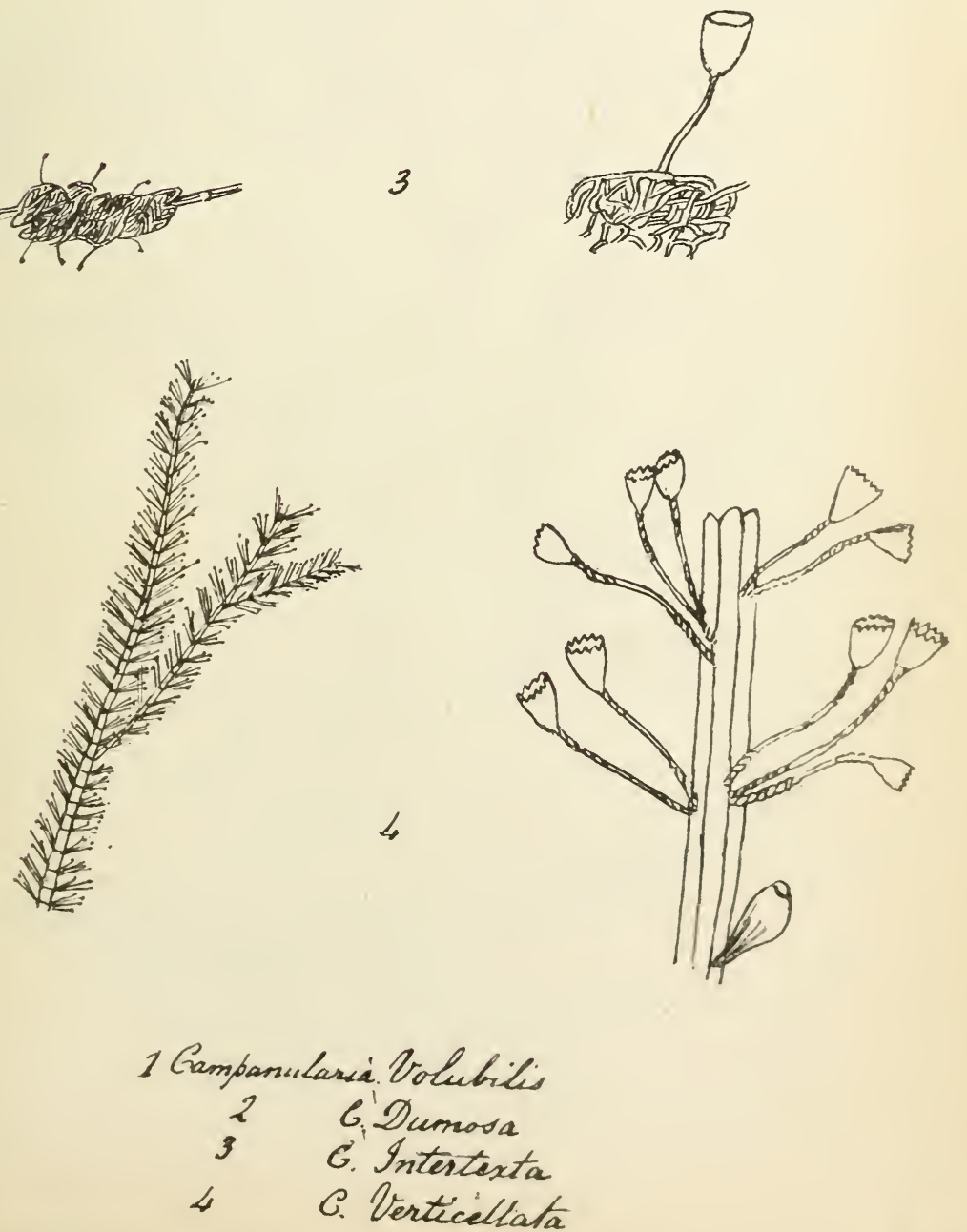

Pl12.
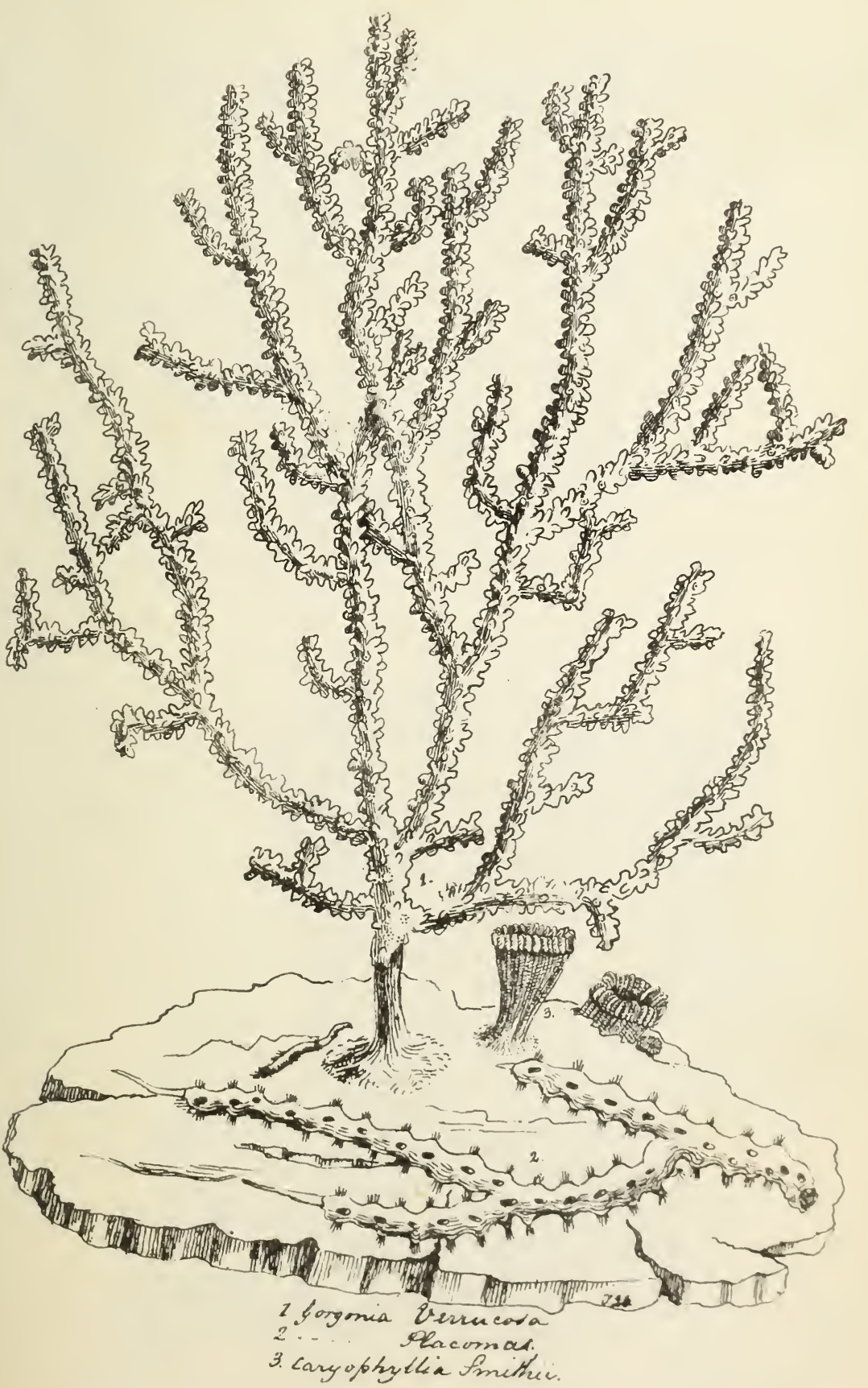


P214
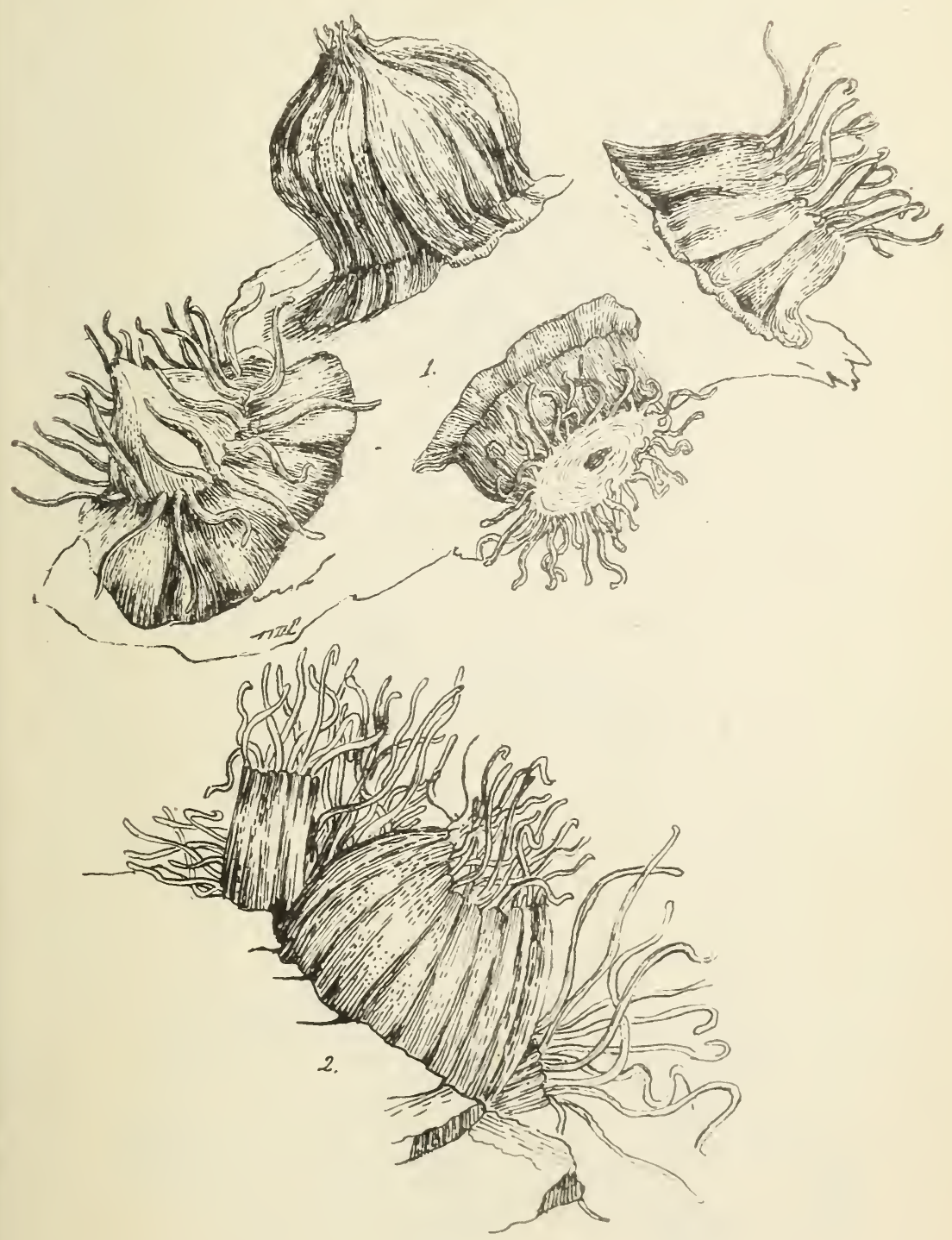

-SActinia Meseonbryanthemum.

2.Sntissa Pereus. 


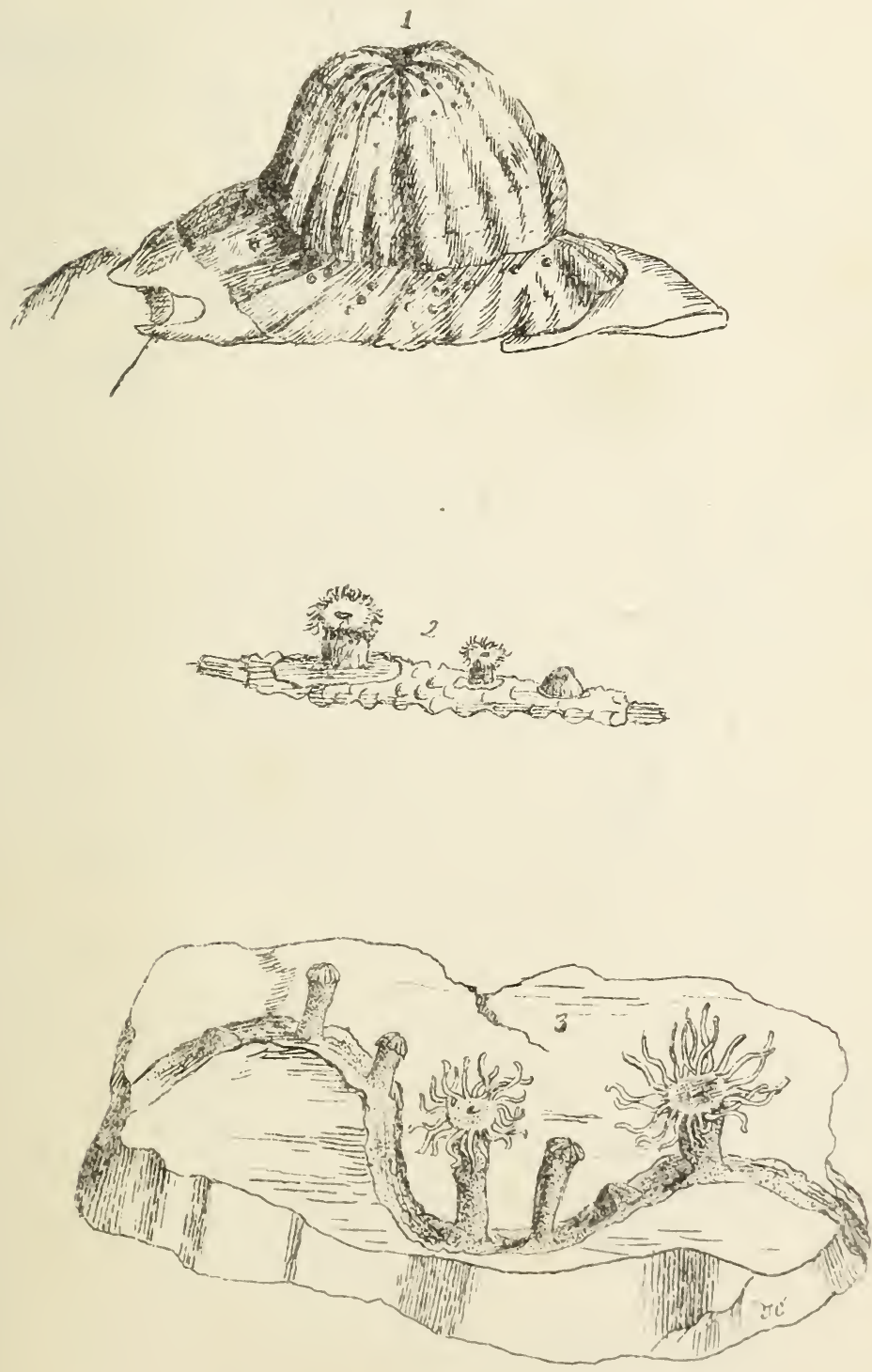

1.2. Actinca Tarasctica

3 Goantines Gouchie. 

PL16.
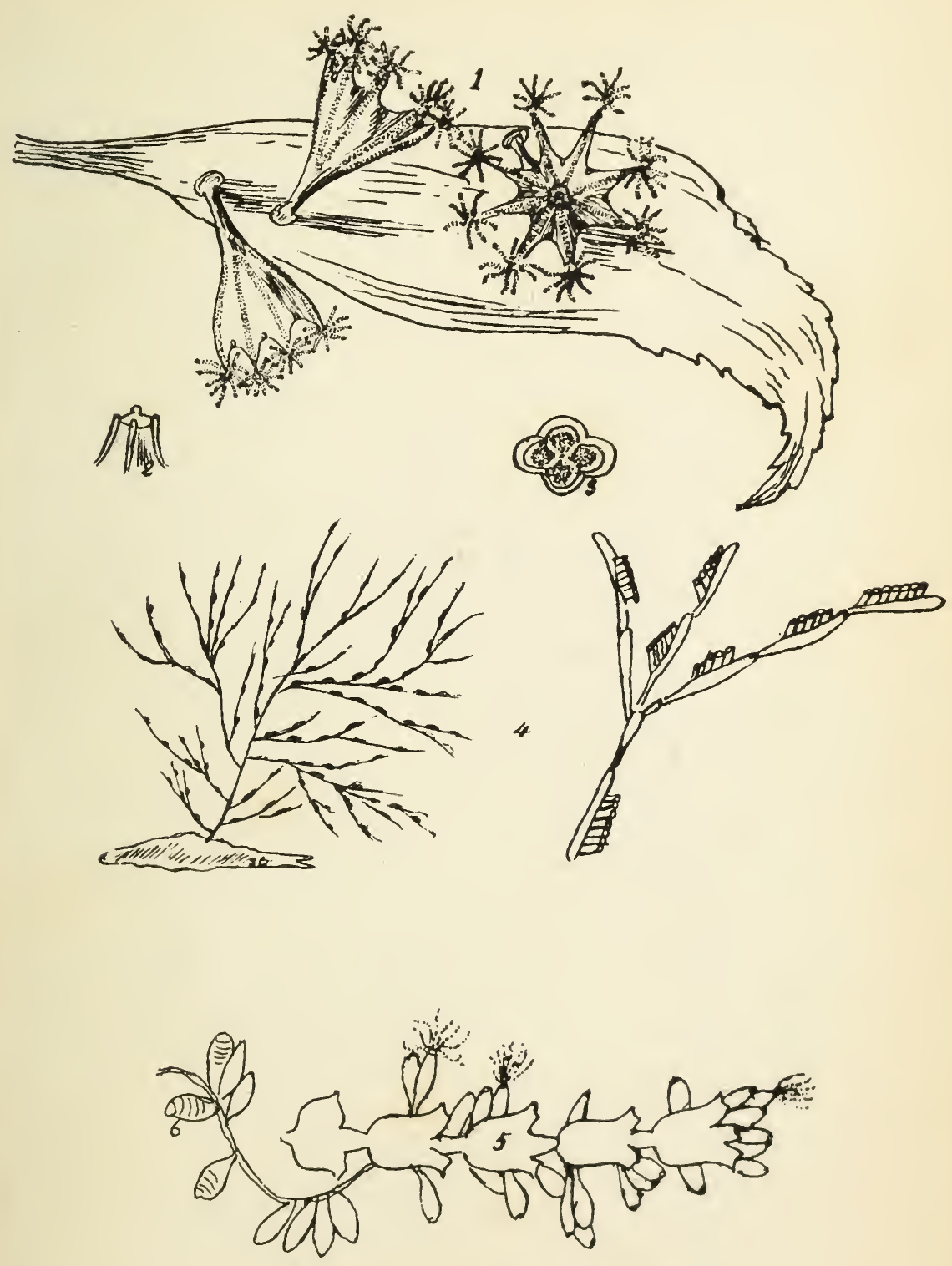

1 Lucernarix Muricula

2.3. Wouth and foot

4 Serialaria Lendigera

5 Eritheria Uva. 



\section{PlY.}

2)

4)

4. 150

4.

4 (vis
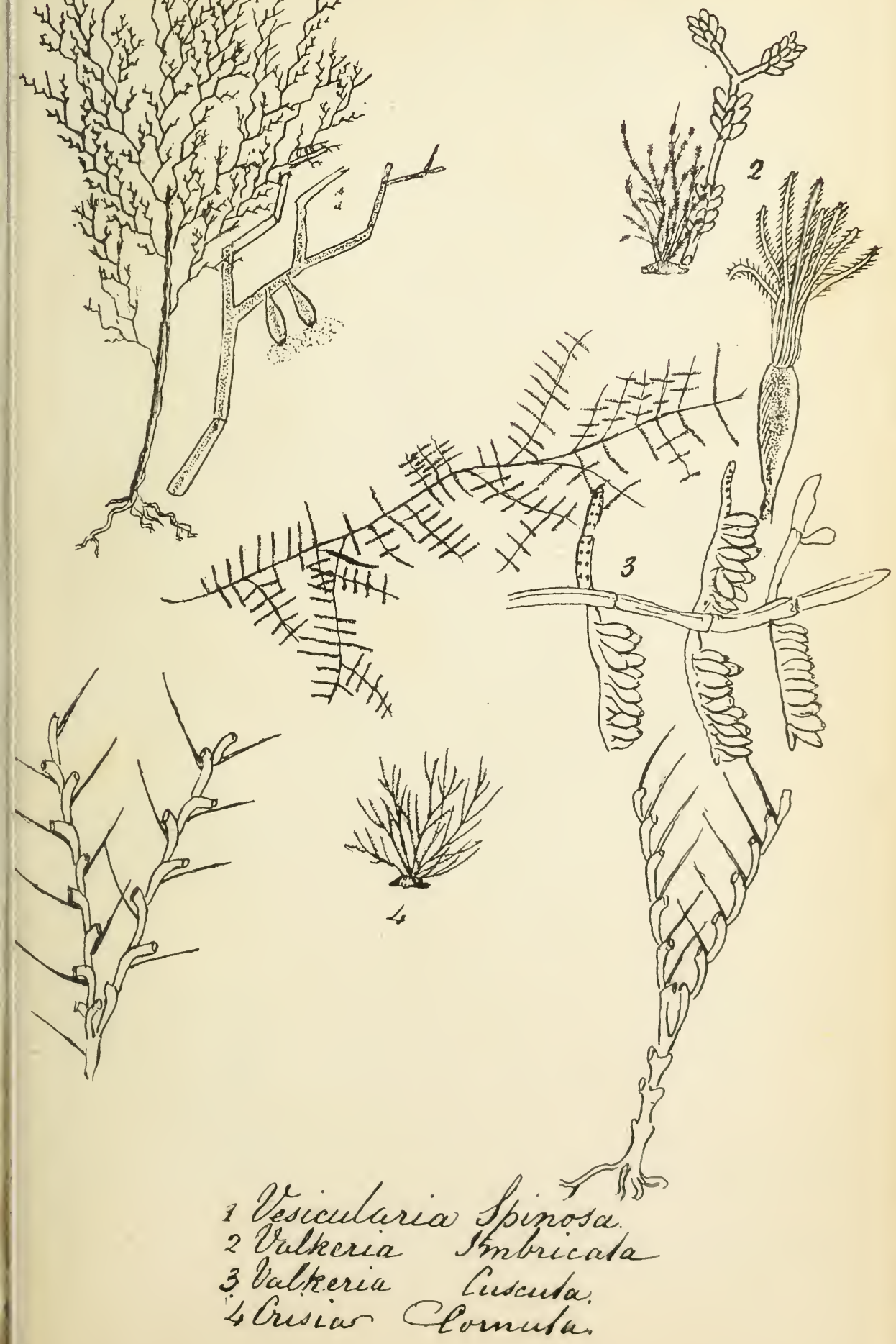


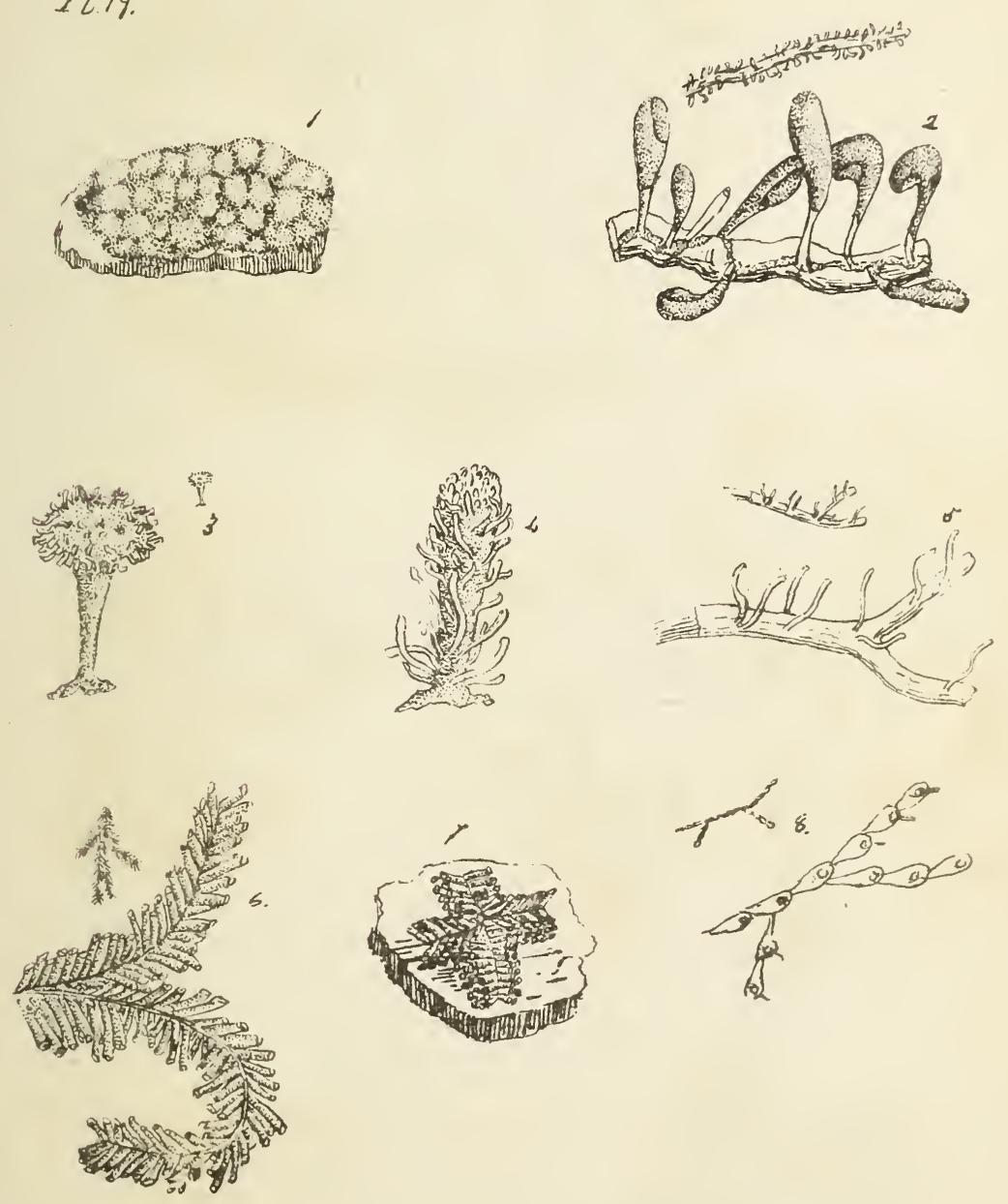

- Discoporarasipida

s Jub. Datrens.

2 Inguin Satulata

6 Sed. Serpens

3 Jubul. Takhend-

y. Jub. Phalangeir

4 Tub. Leflexa.

8. Hifbothoa inca. 



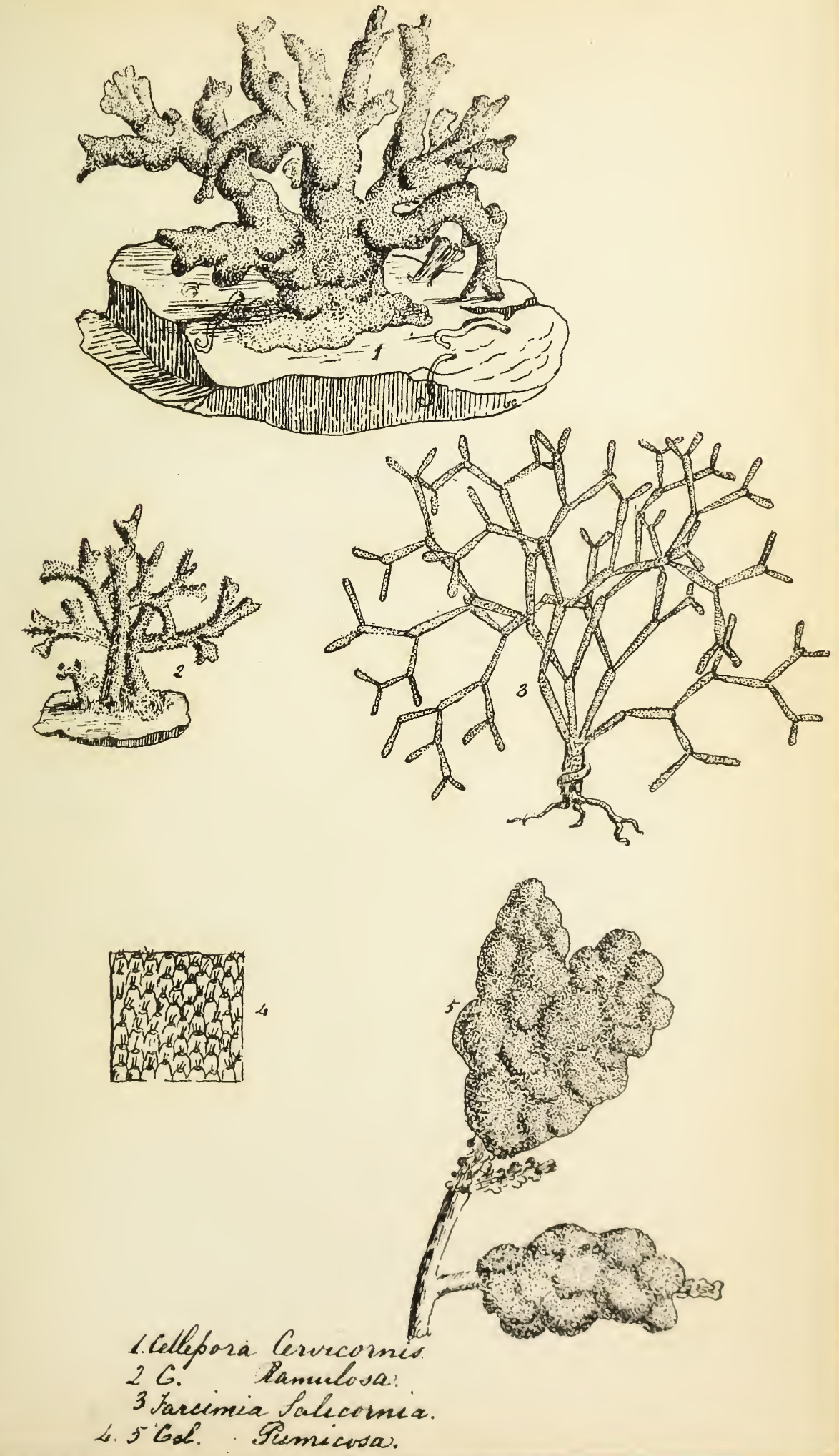



P2.21.

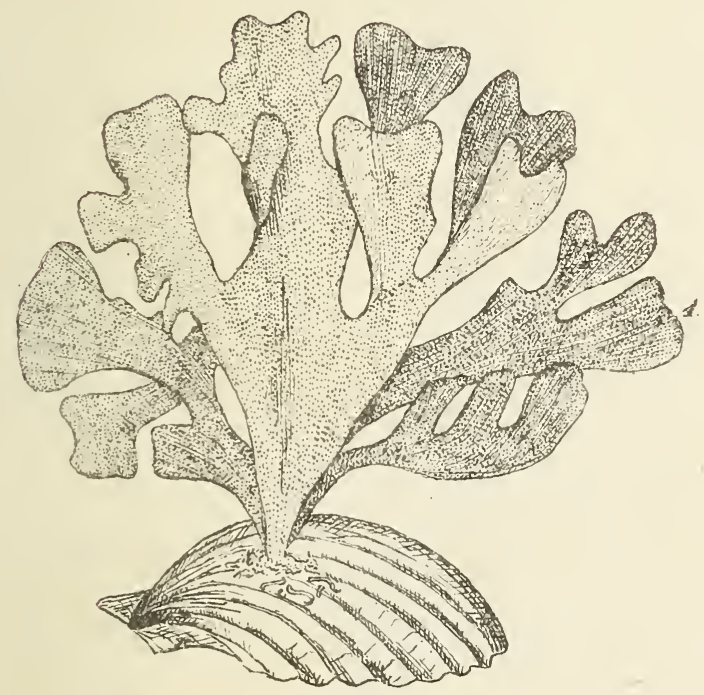

2.
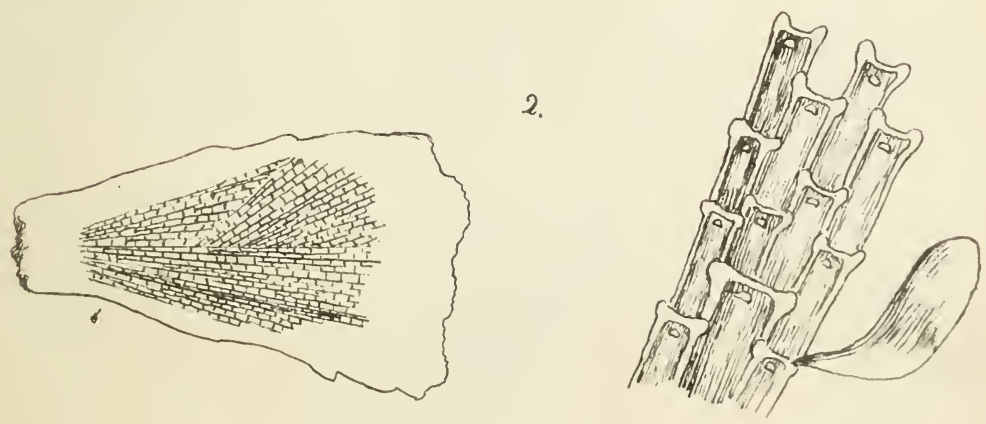

- Hustra Foliacea

2. T. Alembranacia. 

Pl.22.
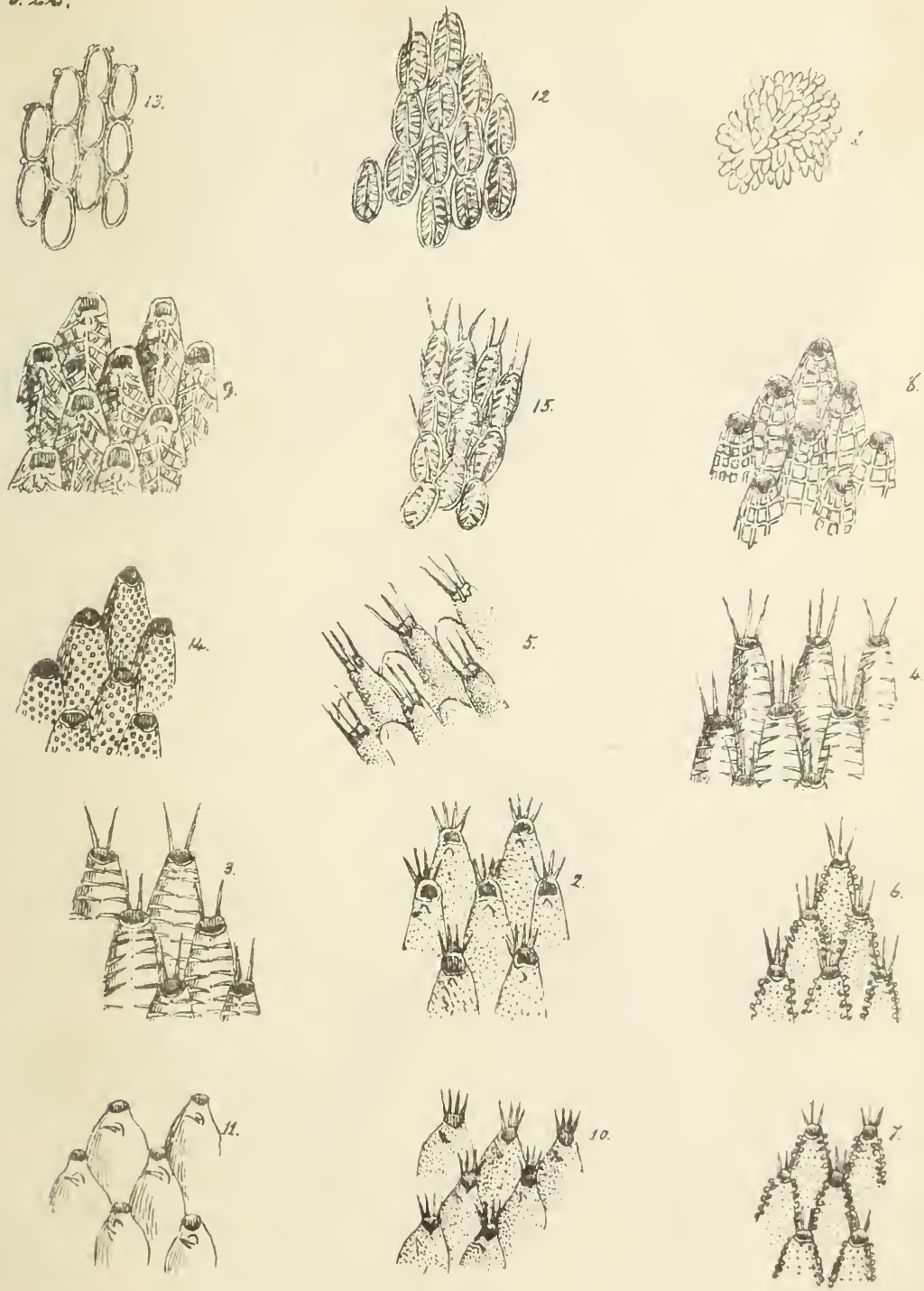

C. Vitrina.

2 Lepralia Rustulara 9 Leprabia Reticulata

32 Silida. $10 \mathrm{~L}$ Ailiara

$42 . \quad$ Innominala "I L Sndener.

52 Judentavia 12 inembanitiratilava

62 Variolosa is lie Peachii

y Is Inca is Leb. Sedetiotams

3.2. Fenestralis 15. Alustra Lineate. yge 
7223.

W W W W

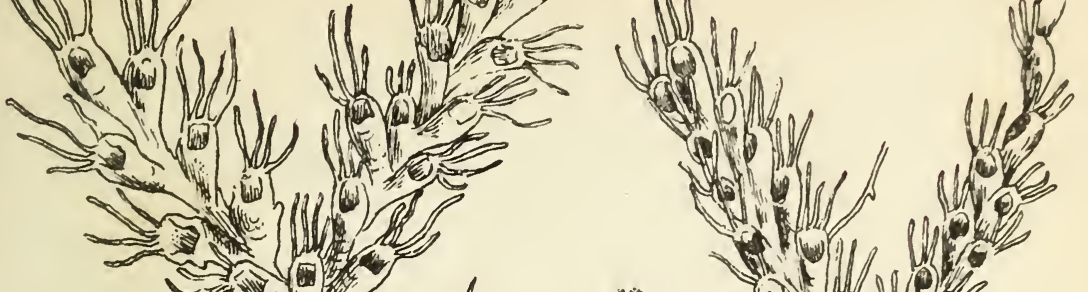
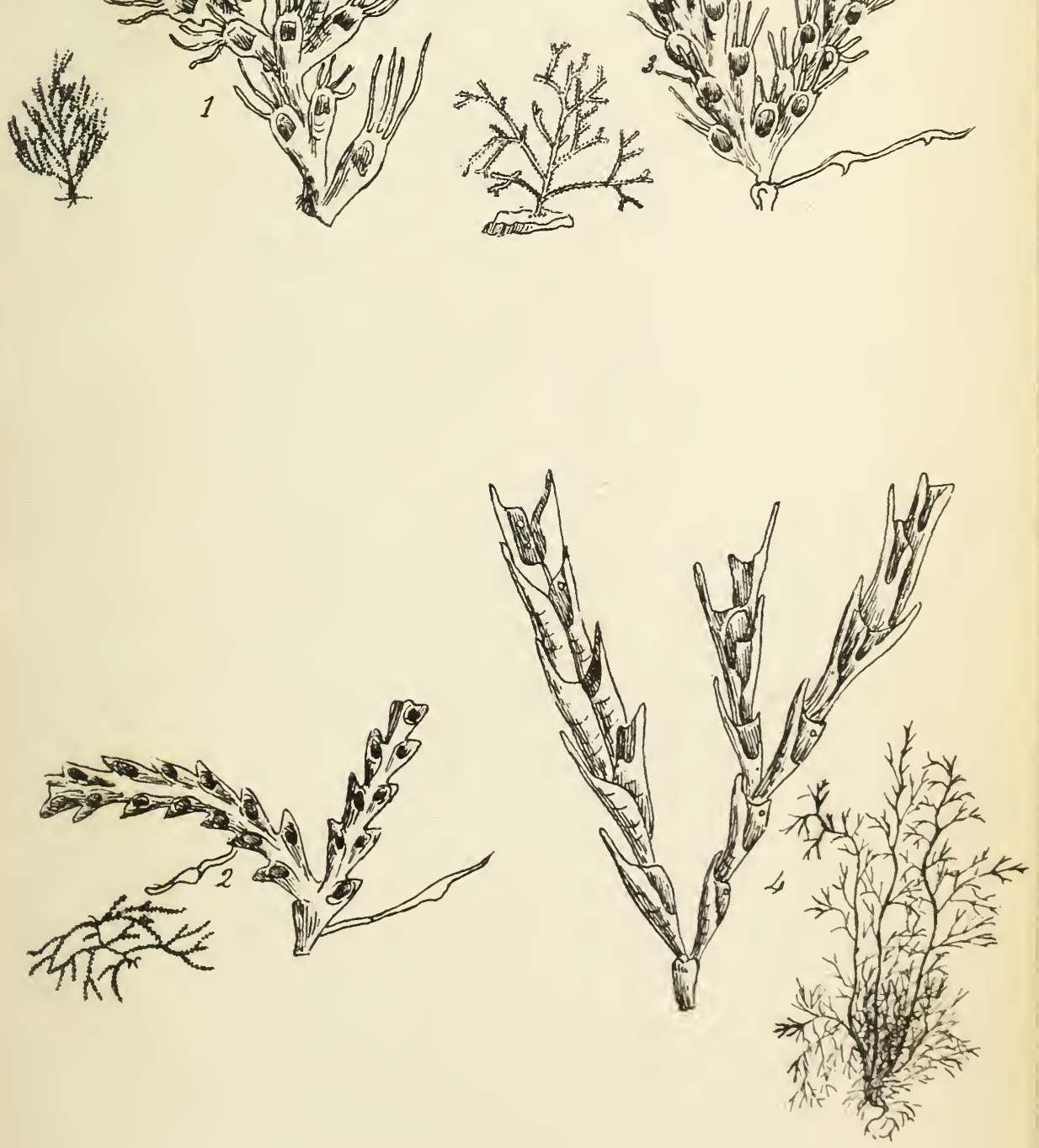

1 Cellularia Lillinta. 3G. Mieptans

2 G Acruposoo. 46 SPlumosa. 


\section{•}





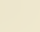





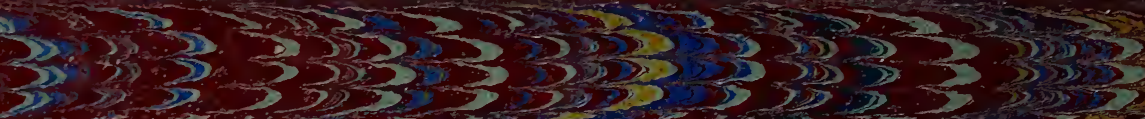

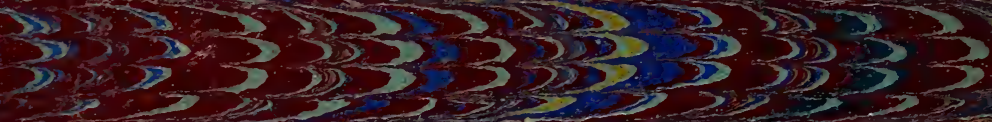

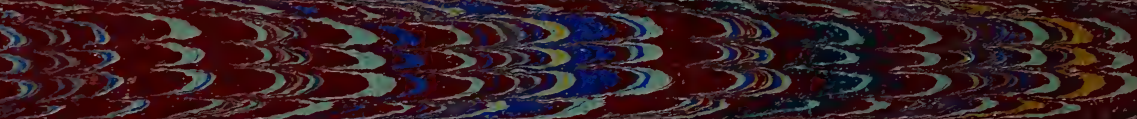

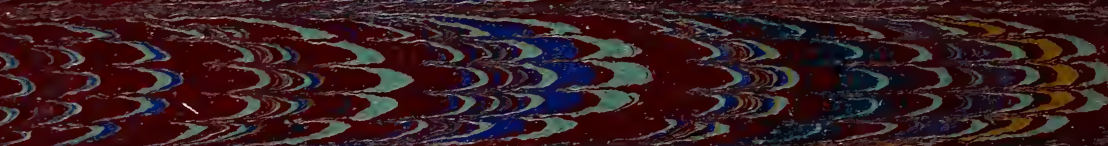
L

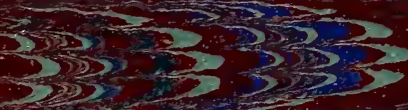
$\therefore ? \geq 3 \frac{15}{35}$

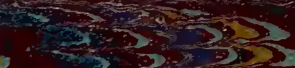
$=2$ Ples

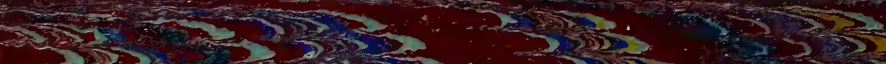

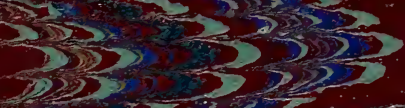

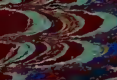
255
2325
32
3
$\sum_{3} 5$ ?
son $x$
$3,3-3,35 ?$

$+5$

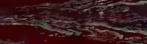

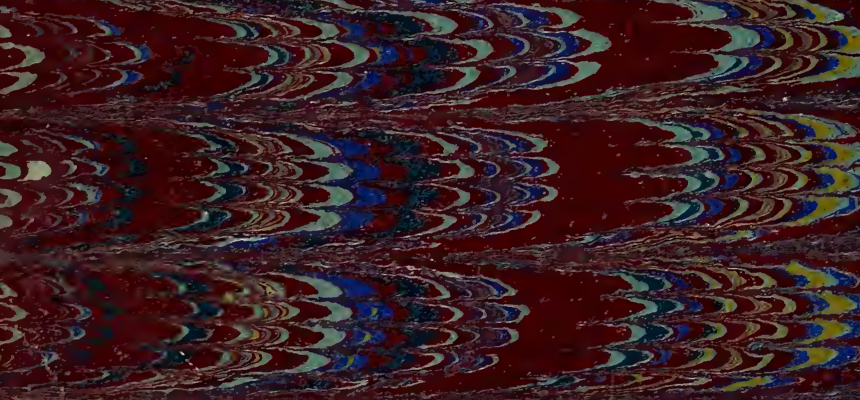

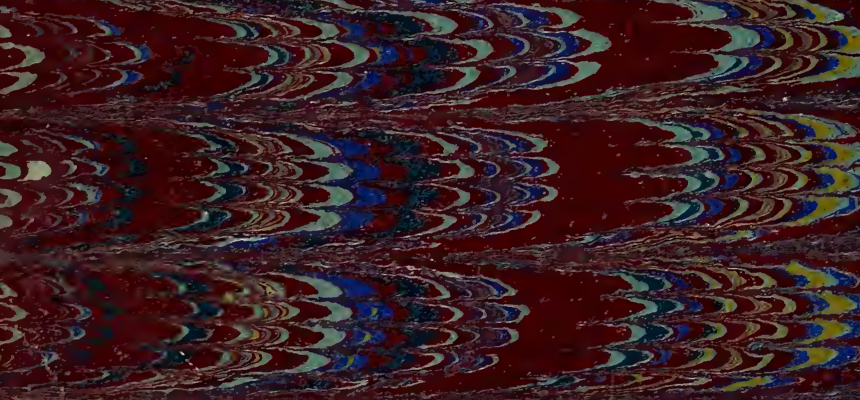

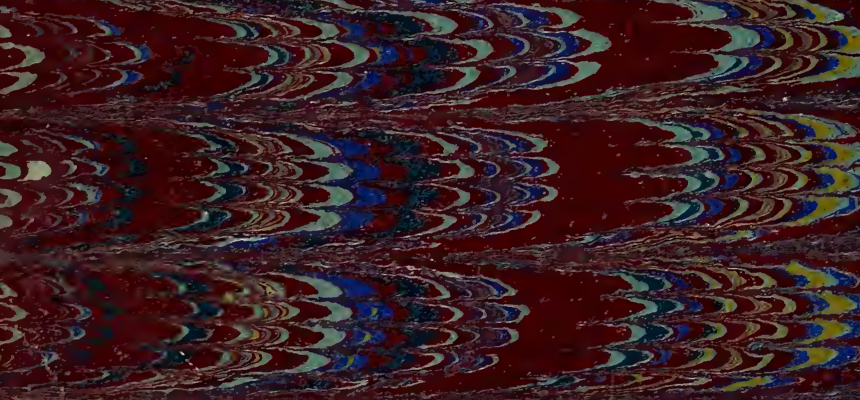

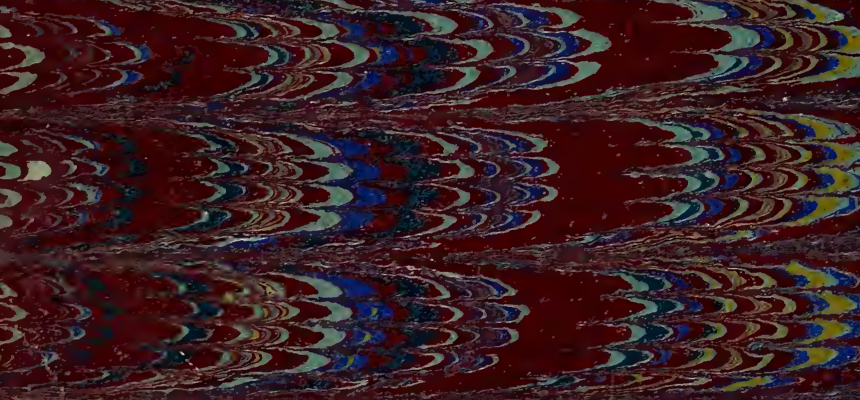

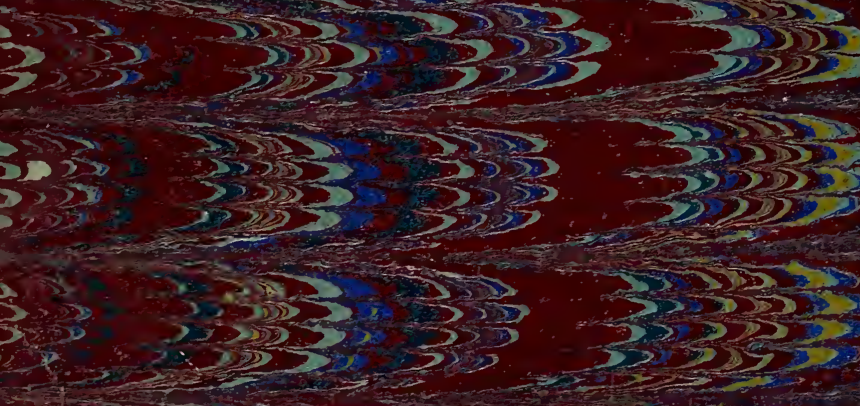

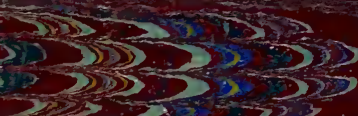

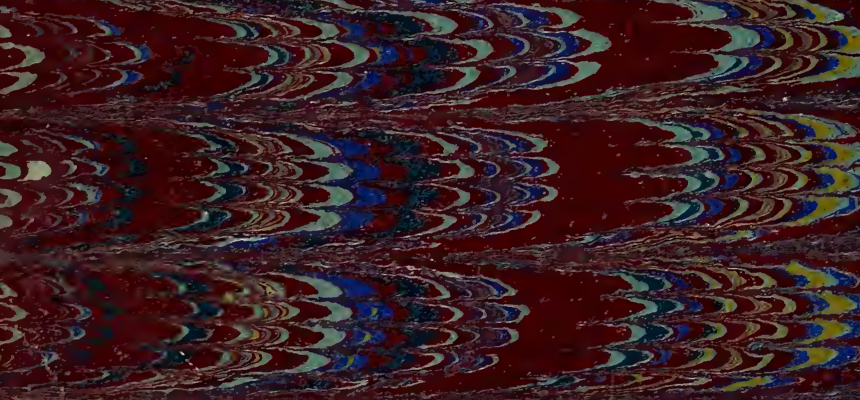

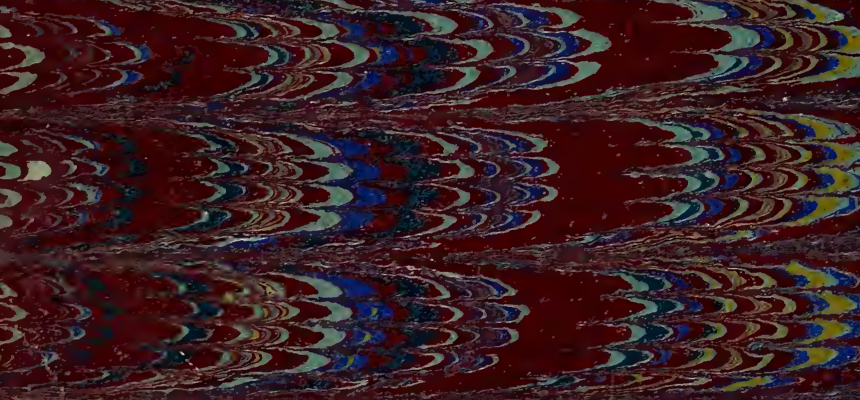

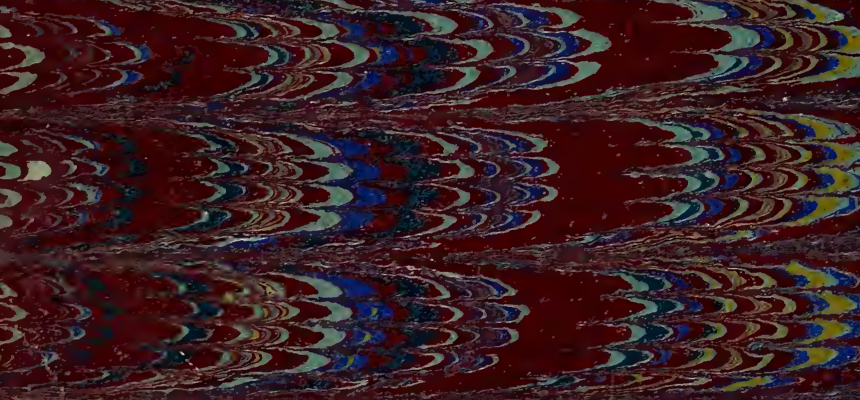

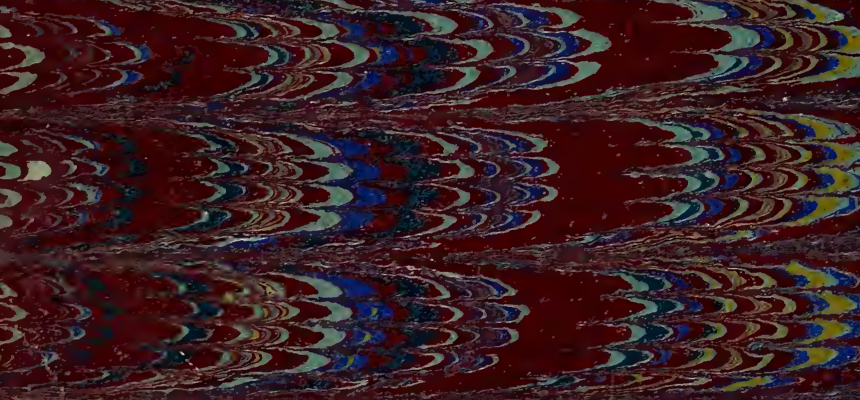

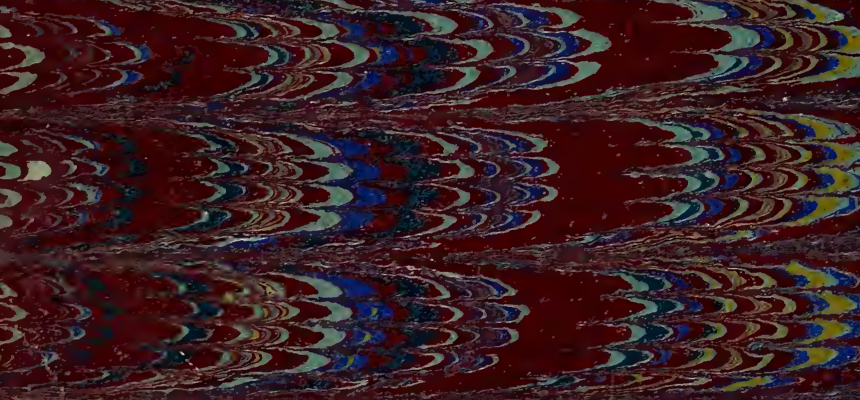

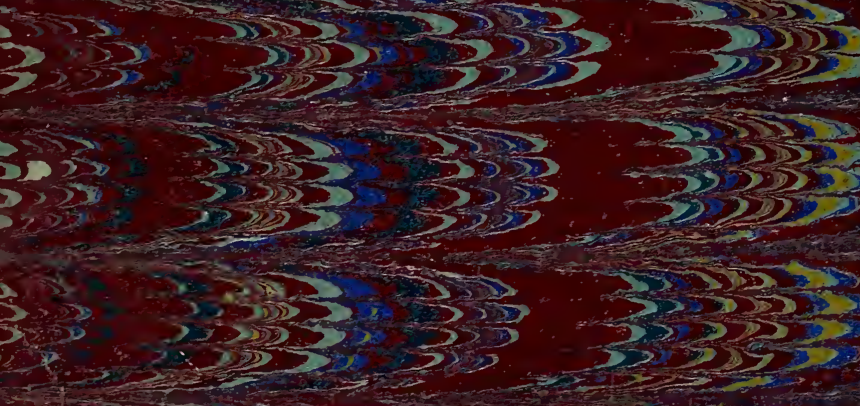

$\sum_{3} \frac{5}{3}$

s).

t,

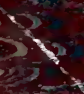

$\rightarrow 5)^{2}$

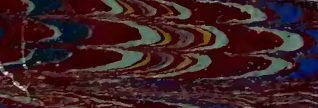

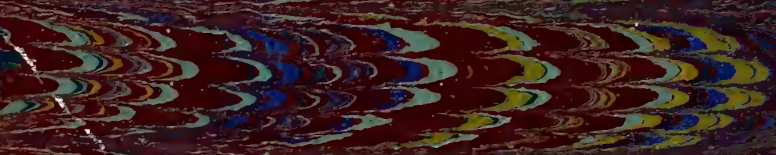

3510 .

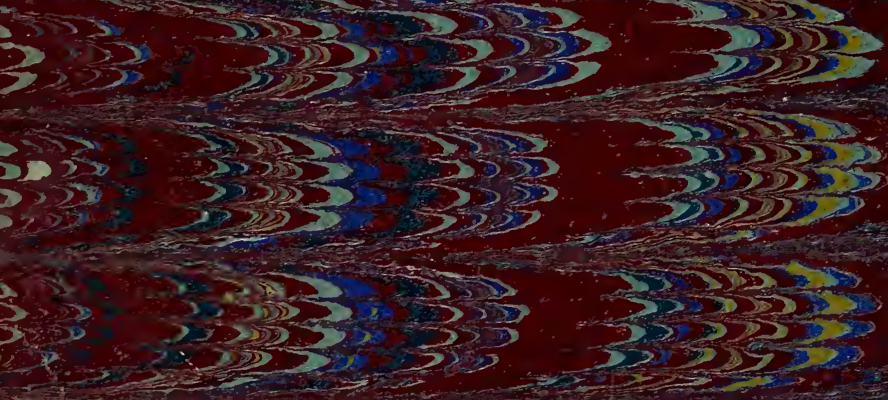

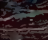

ax $3 \times 2$

$523:-\frac{2}{3}=25$

28

$305 \frac{19}{3}$ 
mobress

$(335,3,35,3,35$

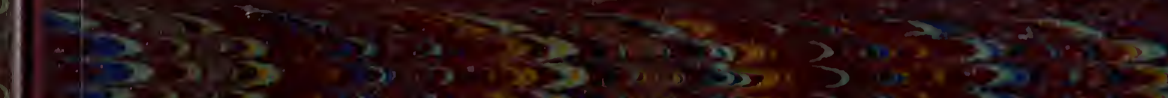

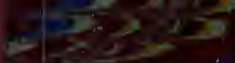

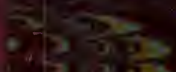

가.

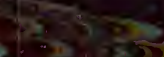

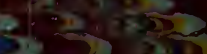

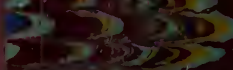

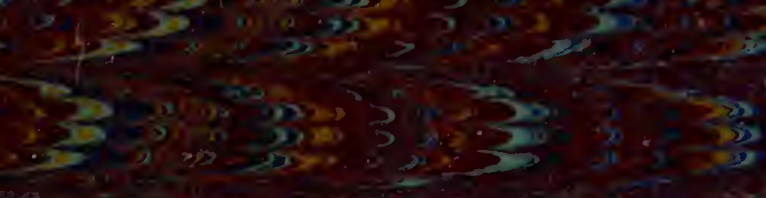

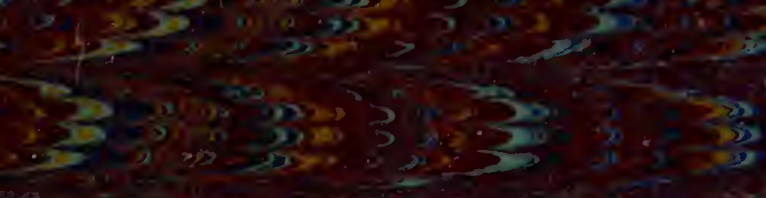

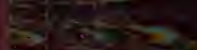

ay -

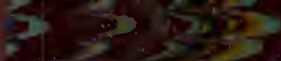

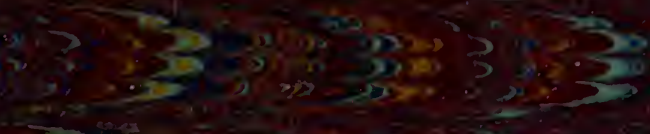

$2 x$

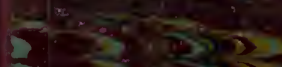

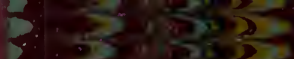

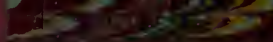

-33 .

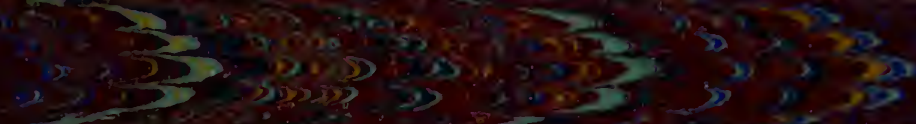

บ

\section{P}

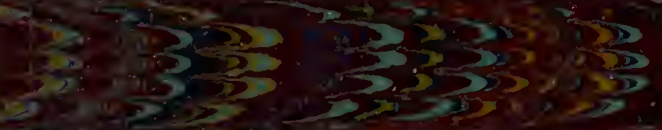

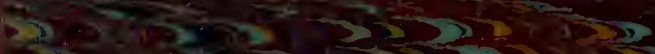

$\frac{5}{3} x^{2}, 83$ is

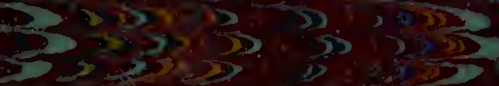

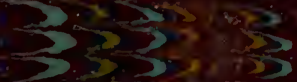

$35,5,25$

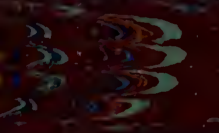

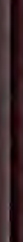

A

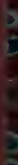

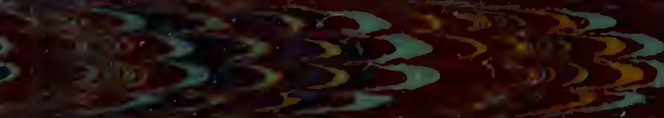

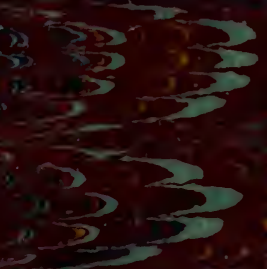

$\frac{3}{2}$

$=$ 3.

(2)

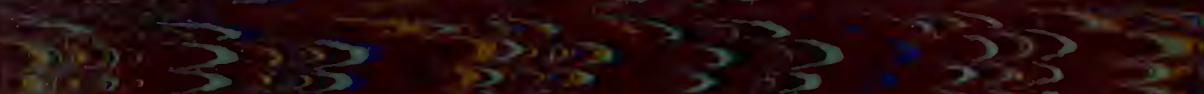

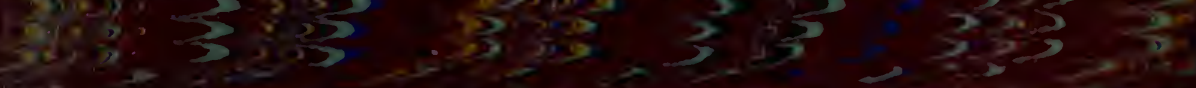

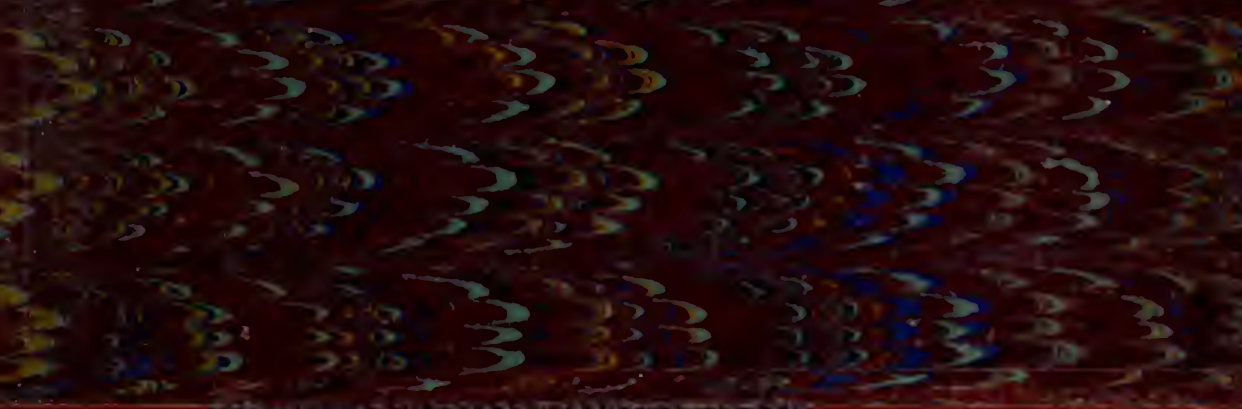




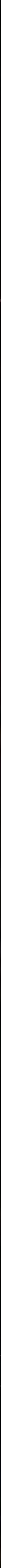

